\title{
Discovery of Surfactins as Inhibitors of microRNA Processing Using cat-ELCCA
}

Andrew W. Robertson, ${ }^{1,2}$ Jorge Sandoval, ${ }^{3}$ Osama G. Mohamed, ${ }^{2,6}$ Yihao Zhuang, ${ }^{2,4}$ Erin E. Gallagher, ${ }^{4}$ Jennifer J. Schmidt, ${ }^{1}$ Lisa Caratelli, ${ }^{4}$ Arya Menon, ${ }^{4}$ Pamela J. Schultz, ${ }^{1,2}$ Rachel M. Torrez, ${ }^{1,4}$ Catherine L. Hay, ${ }^{2}$ Bailey A. Bell, ${ }^{2}$ Paul A. Price, ${ }^{5}$ Amanda L. Garner, ${ }^{3,4^{*}}$ Ashootosh Tripathi ${ }^{1,2,4^{*}}$

${ }^{1}$ Life Sciences Institute, University of Michigan, 210 Washtenaw Avenue, Ann Arbor, MI 48109, USA

${ }^{2}$ Natural Products Discovery Core, University of Michigan, 210 Washtenaw Avenue, Ann Arbor, MI 48109, USA

${ }^{3}$ Program in Chemical Biology, University of Michigan, 210 Washtenaw Avenue, Ann Arbor, Michigan 48109, USA

${ }^{4}$ Department of Medicinal Chemistry, College of Pharmacy, University of Michigan, 428 Church Street, Ann Arbor, Michigan 48109, USA

${ }^{5}$ Biology Department, Eastern Michigan University, Ypsilanti, Michigan, USA

${ }^{6}$ Pharmacognosy Department, Faculty of Pharmacy, Cairo University, Kasr el-Aini Street, Cairo 11562, Egypt

Materials and Methods

GNPS Analysis

Figure S1. Complete GNPS molecular network for surfactins detected in 82379-N6R crude extract. 82379-N6R red nodes, and A3M medium blue nodes.

Figure S2. GNPS molecular network for fusaricidin family detected in Paenibacillus sp. PAP203 crude

extract.

Purification

Figure S3. Initial Biotage fractionation of crude extract from sp. 82379-N6R. Solvent $\mathrm{A}: \mathrm{H}_{2} \mathrm{O}$; solvent B: $\mathrm{MeOH}$; solvent C: $\mathrm{ACN}$; $\mathrm{C} 18$ (40 g), flow rate $40 \mathrm{mLmin}^{-1}$. Elution was monitored at $200 \mathrm{~nm}$ (red), 254 $\mathrm{nm}$ (blue), and $\lambda$-all (black, $198-400 \mathrm{~nm}$ ).

Figure S4. Initial HPLC fractionation of F7 (Figure S2) from Biotage cleanup. Solvent $\mathrm{A}: \mathrm{H}_{2} \mathrm{O}+0.1 \% \mathrm{FA}$ (33\%); solvent B: ACN (77\%); C18 $(250 \times 21.2)$ flow rate $9 \mathrm{mLmin}^{-1}$.

Figure S5. Final HPLC purification of F7_0 through F7_6 (compounds 1-6 respectively) monitoring at $200 \mathrm{~nm}$.

Figure S6. Initial Biotage fractionation of crude extract from sp. R312_4. Solvent A: $\mathrm{H}_{2} \mathrm{O}$; solvent B: $\mathrm{MeOH}$; solvent C: ACN; C18 (12 g), flow rate $20 \mathrm{mLmin}^{-1}$. Elution was monitored at $200 \mathrm{~nm}$ (red), 254 $\mathrm{nm}$ (blue), and $\lambda$-all (black, 198-400 $\mathrm{nm}$ ).

Figure S7. HPLC fractionation of $F 4 / C e l l$ extract from Biotage cleanup (see figure S5). Step 1: Solvent $A$ $\mathrm{H}_{2} \mathrm{O}+0.1 \%$ FA (53\%); solvent B: ACN (47\%) 0-15 min; Step 2: Solvent A $\mathrm{H}_{2} \mathrm{O}+0.1 \%$ FA (22\%); solvent B: ACN (78\%) 15-80 min Phenomenex Luna $5 \mu \mathrm{m} \mathrm{C18}(250 \times 21.2 \mathrm{~mm})$ flow rate $4 \mathrm{mLmin}^{-1} \ldots \ldots \ldots \ldots . . .16$ 
Figure S8. Overlaid LC-MS trace of surfactins 1-6, monitored at $200 \mathrm{~nm}$. Samples were analyzed using a Phenomenex Kinetex $5 \mu \mathrm{m}$ Phenyl-Hexyl $100 \AA ̊$ column $(100 \times 4.6 \mathrm{~mm})$ flow rate of $0.4 \mathrm{mLmin}-1 \ldots 17$

Figure S9. Single LC-MS traces of surfactins 1-6, monitored at $200 \mathrm{~nm}$, with retention times (min).... 17

Figure S10. Overlaid LC-MS trace of surfactins and mycosubtilins 7-9, monitored at $200 \mathrm{~nm}$. Samples were analyzed using a Phenomenex Kinetex $5 \mu \mathrm{m}$ Phenyl-Hexyl $100 \AA ̊$ column $(100 \times 4.6 \mathrm{~mm})$ flow rate of $0.4 \mathrm{mLmin}^{-1}$

Figure S11. Single LC-MS traces of surfactins and mycosubtilins 7-9, monitored at $200 \mathrm{~nm}$, with

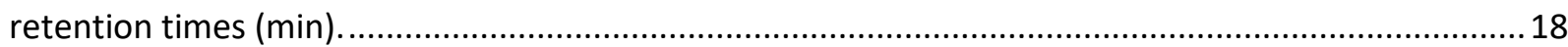

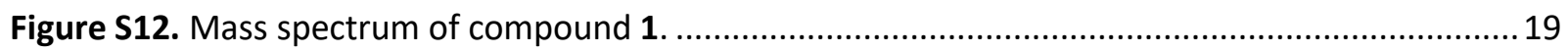

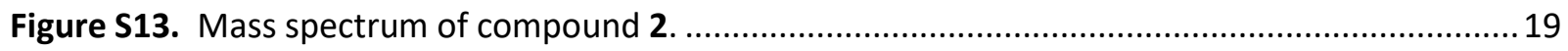

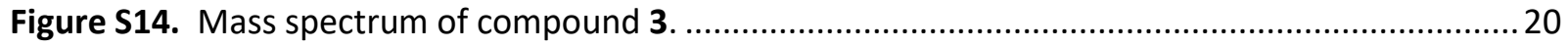

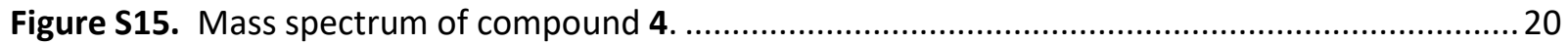

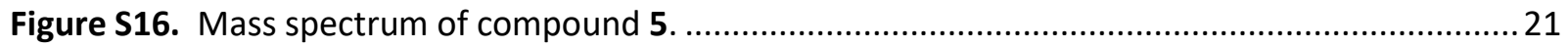

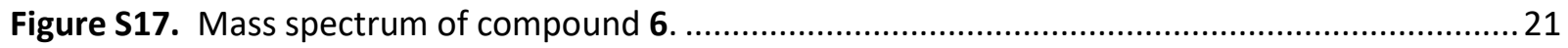

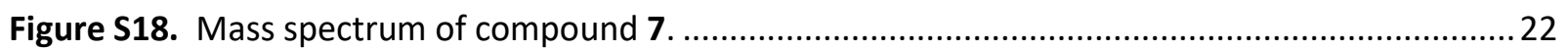

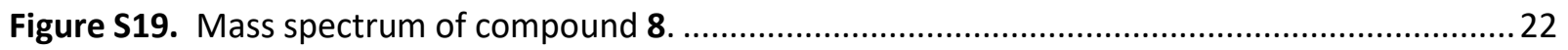

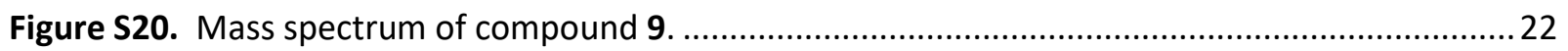

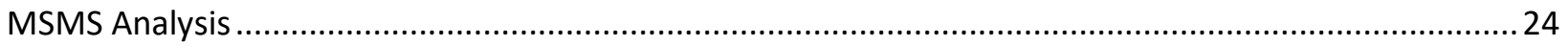

Figure S23. Characteristic fragments of linearized 1a-6a in tandem MS experiments. Dashed lines through amide linkages illustrate " $y$ " and "b" fragments obtained...................................................24

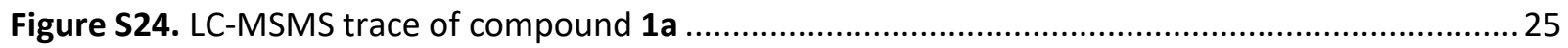

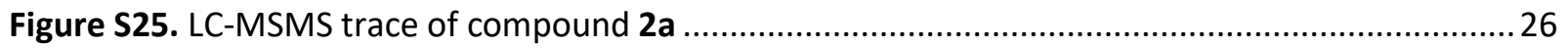

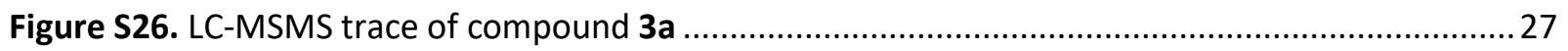

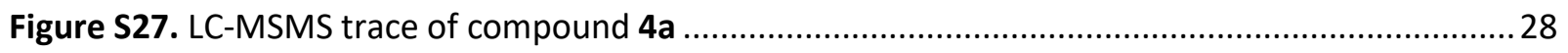

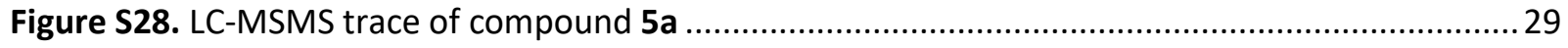

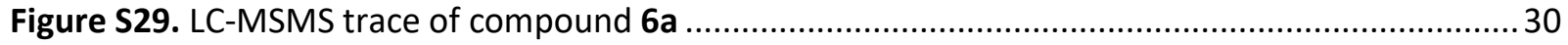

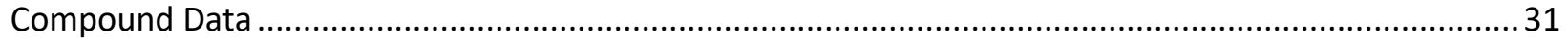

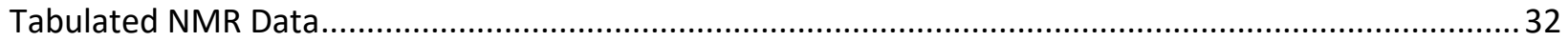

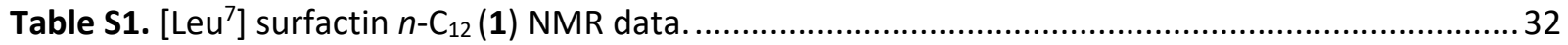

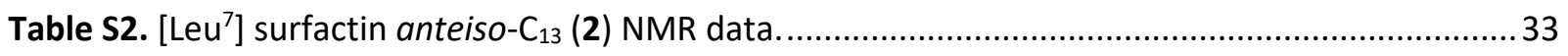

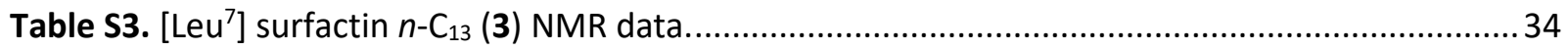

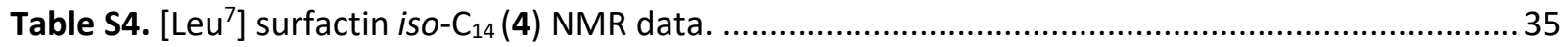

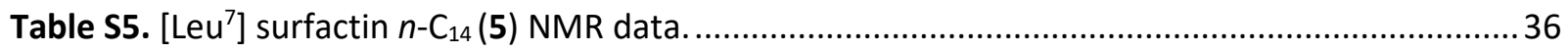

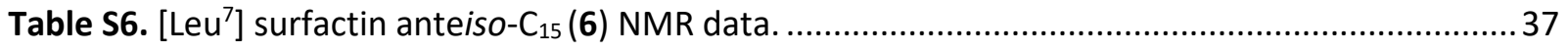




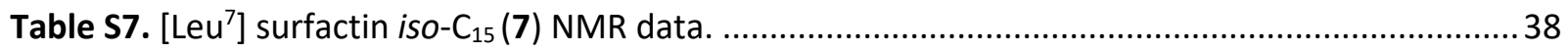

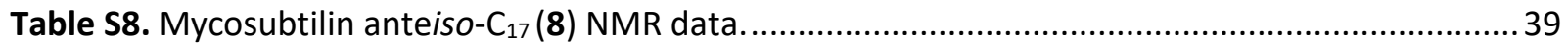

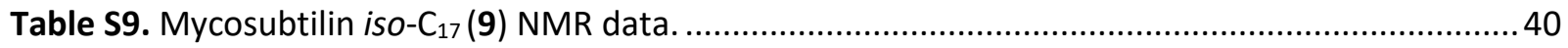

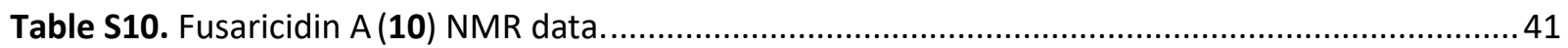

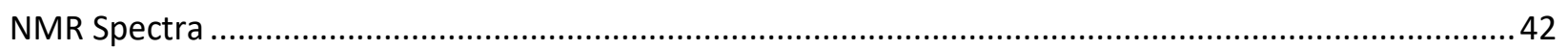

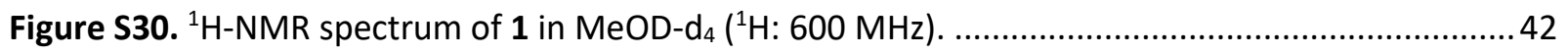

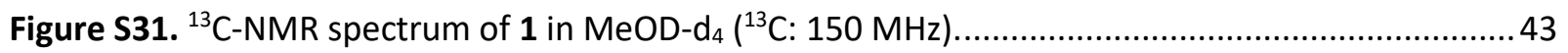

Figure S32. ${ }^{13} \mathrm{C}-\mathrm{NMR}$ spectrum of 1 in $\mathrm{MeOD}-\mathrm{d}_{4}\left({ }^{13} \mathrm{C}: 150 \mathrm{MHz}\right)$, illustrating important methyl peaks

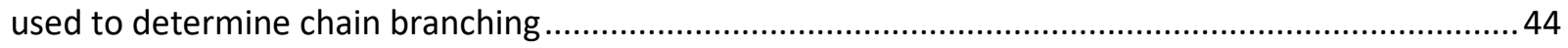

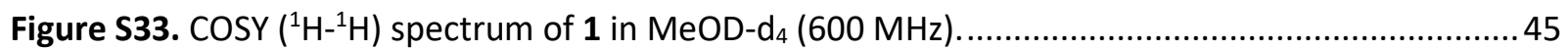

Figure S34. HSQC $\left({ }^{1} \mathrm{H}_{-}{ }^{13} \mathrm{C}\right)$ spectrum of 1 in MeOD- $\mathrm{d}_{4}$. Red contours represent $\mathrm{CH}$ and $\mathrm{CH}_{3}$ groups, blue

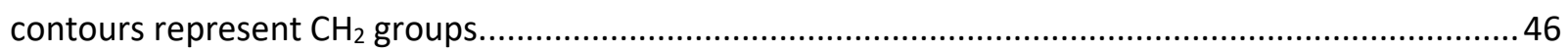

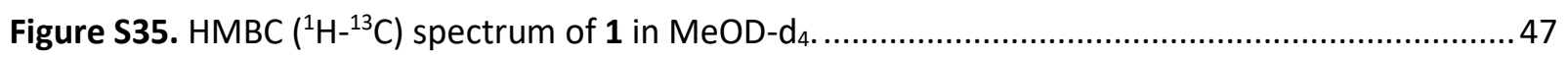

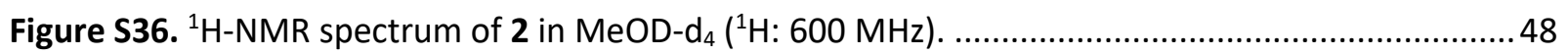

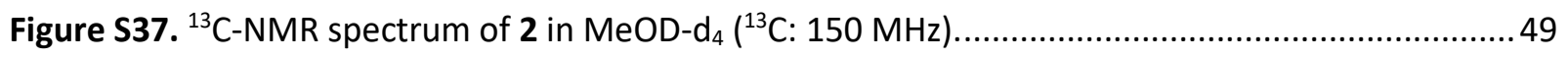

Figure S38. ${ }^{13} \mathrm{C}-\mathrm{NMR}$ spectrum of $\mathbf{2}$ in $\mathrm{MeOD}-\mathrm{d}_{4}\left({ }^{13} \mathrm{C}: 150 \mathrm{MHz}\right)$, illustrating important methyl peaks

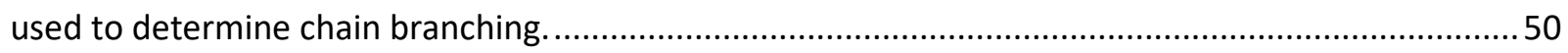

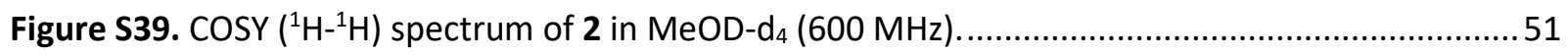

Figure S40. HSQC $\left({ }^{1} \mathrm{H}_{-}{ }^{13} \mathrm{C}\right)$ spectrum of 2 in MeOD- $\mathrm{d}_{4}$. Red contours represent $\mathrm{CH}$ and $\mathrm{CH}_{3}$ groups, blue

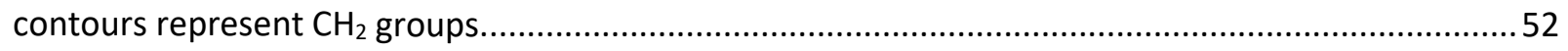

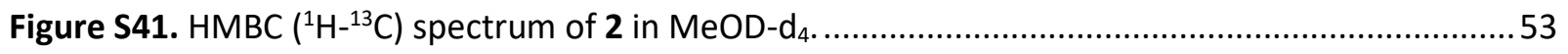

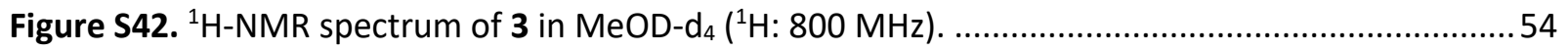

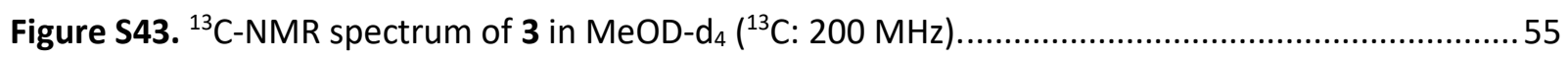

Figure S44. ${ }^{13} \mathrm{C}-\mathrm{NMR}$ spectrum of 3 in MeOD-d $\left({ }^{13} \mathrm{C}: 200 \mathrm{MHz}\right)$, illustrating important methyl peaks

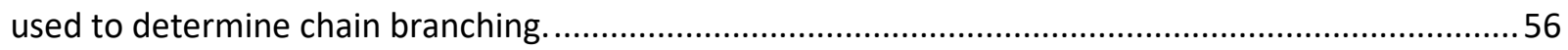

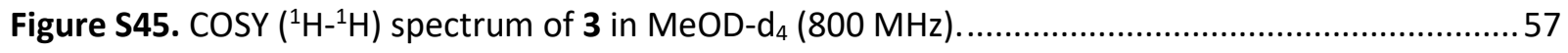

Figure S46. HSQC $\left({ }^{1} \mathrm{H}_{-}{ }^{13} \mathrm{C}\right)$ spectrum of 3 in MeOD- $\mathrm{d}_{4}$. Red contours represent $\mathrm{CH}$ and $\mathrm{CH}_{3}$ groups, blue

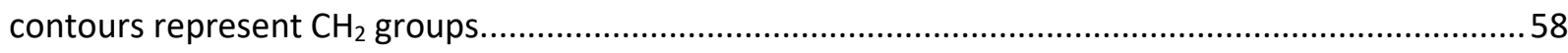

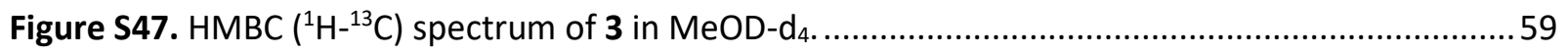

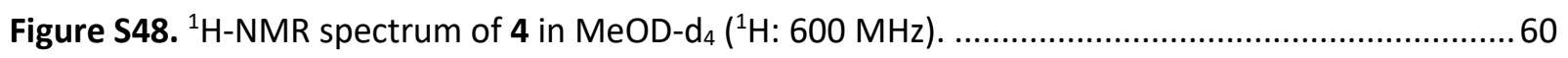

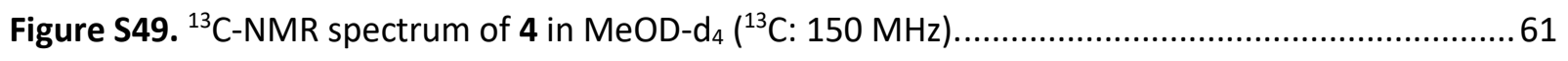

Figure S50. ${ }^{13} \mathrm{C}-\mathrm{NMR}$ spectrum of 4 in $\mathrm{MeOD}-\mathrm{d}_{4}\left({ }^{13} \mathrm{C}: 150 \mathrm{MHz}\right)$, illustrating important methyl peaks

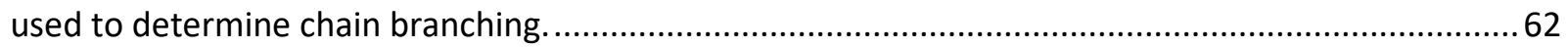

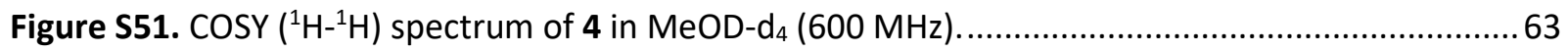


Figure S52. $\mathrm{HSQC}\left({ }^{1} \mathrm{H}^{-13} \mathrm{C}\right)$ spectrum of 4 in MeOD- $\mathrm{d}_{4}$. Red contours represent $\mathrm{CH}$ and $\mathrm{CH}_{3}$ groups, blue

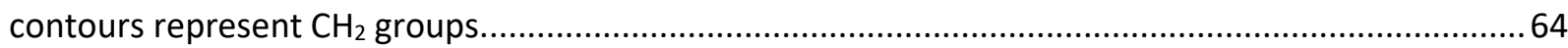

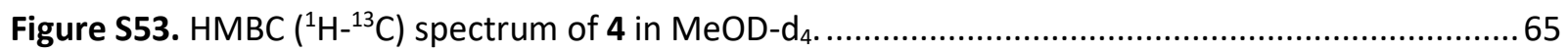

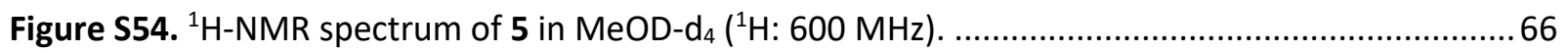

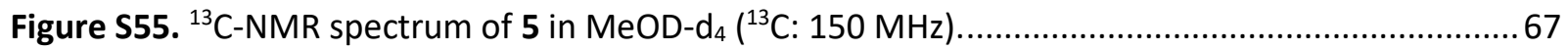

Figure S56. ${ }^{13} \mathrm{C}-\mathrm{NMR}$ spectrum of 5 in MeOD- $\mathrm{d}_{4}\left({ }^{13} \mathrm{C}: 150 \mathrm{MHz}\right)$, illustrating important methyl peaks

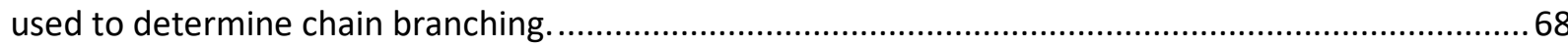

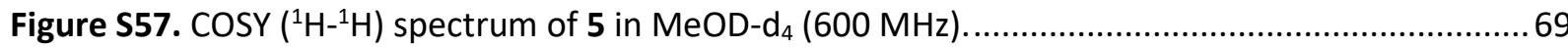

Figure S58. $\mathrm{HSQC}\left({ }^{1} \mathrm{H}^{13} \mathrm{C}\right)$ spectrum of 5 in MeOD- $\mathrm{d}_{4}$. Red contours represent $\mathrm{CH}$ and $\mathrm{CH}_{3}$ groups, blue

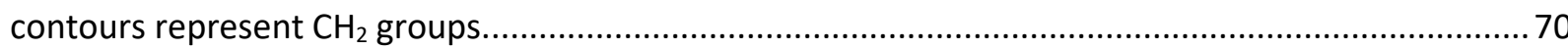

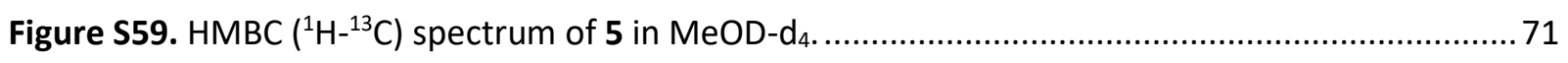

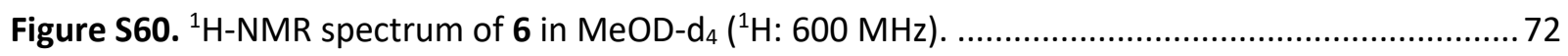

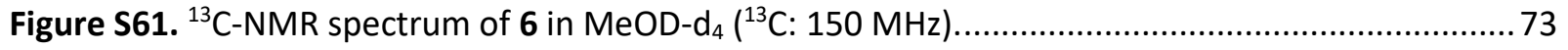

Figure S62. ${ }^{13} \mathrm{C}-\mathrm{NMR}$ spectrum of 6 in MeOD- $\mathrm{d}_{4}\left({ }^{13} \mathrm{C}: 150 \mathrm{MHz}\right)$, illustrating important methyl peaks

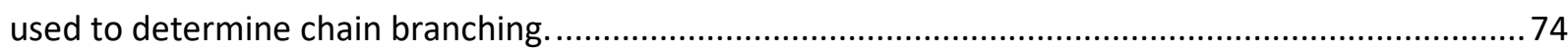

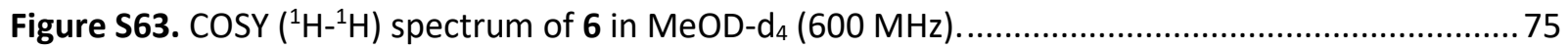

Figure S64. $\mathrm{HSQC}\left({ }^{1} \mathrm{H}^{-13} \mathrm{C}\right)$ spectrum of 6 in MeOD- $\mathrm{d}_{4}$. Red contours represent $\mathrm{CH}$ and $\mathrm{CH}_{3}$ groups, blue

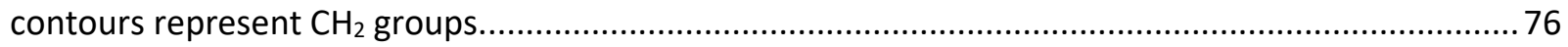

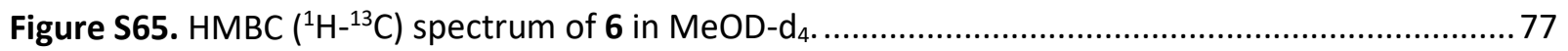

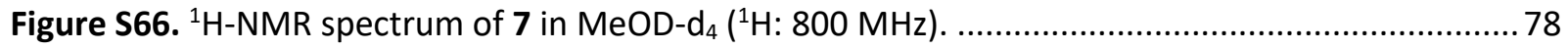

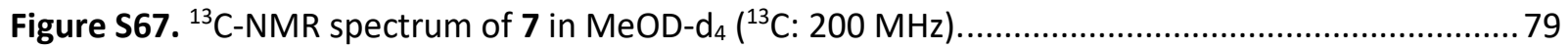

Figure S68. ${ }^{13} \mathrm{C}-\mathrm{NMR}$ spectrum of $\mathbf{7}$ in $\mathrm{MeOD}-\mathrm{d}_{4}\left({ }^{13} \mathrm{C}: 200 \mathrm{MHz}\right)$, illustrating important methyl peaks

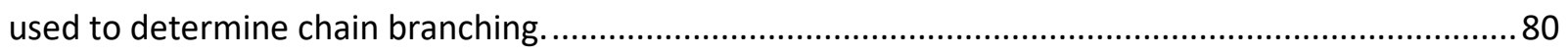

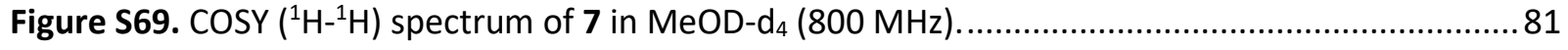

Figure S70. HSQC $\left({ }^{1} \mathrm{H}_{-}{ }^{13} \mathrm{C}\right)$ spectrum of 7 in MeOD- $\mathrm{d}_{4}$. Red contours represent $\mathrm{CH}$ and $\mathrm{CH}_{3}$ groups, blue

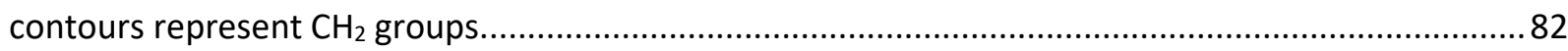

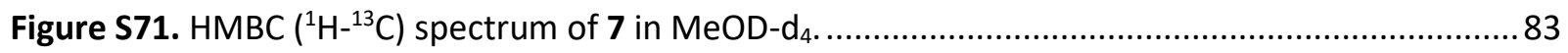

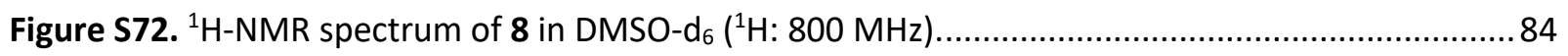

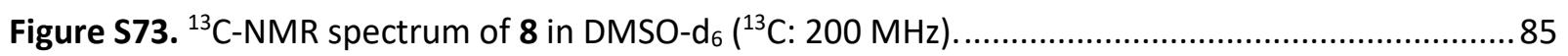

Figure S74. ${ }^{13} \mathrm{C}-\mathrm{NMR}$ spectrum of 8 in DMSO- $\mathrm{d}_{6}\left({ }^{13} \mathrm{C}: 200 \mathrm{MHz}\right)$, illustrating important methyl peaks

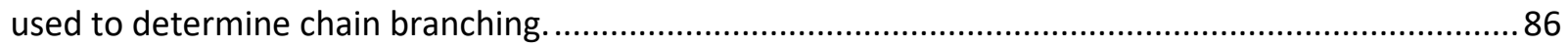

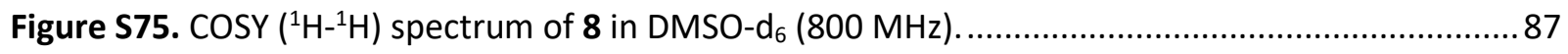

Figure S76. HSQC $\left({ }^{1} \mathrm{H}_{-}{ }^{13} \mathrm{C}\right)$ spectrum of 8 in DMSO- $\mathrm{d}_{6}$. Red contours represent $\mathrm{CH}$ and $\mathrm{CH}_{3}$ groups, blue

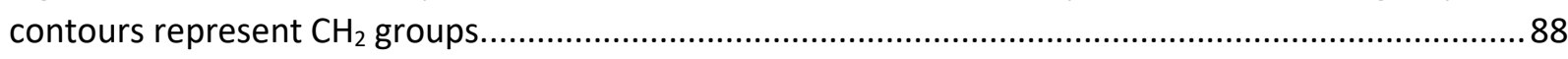

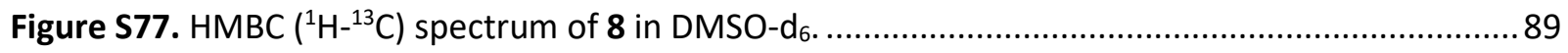




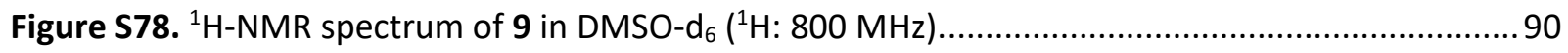

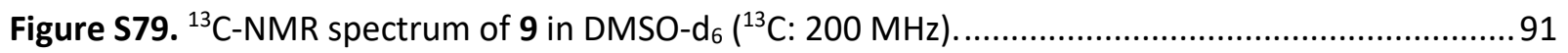

Figure S80. ${ }^{13} \mathrm{C}-\mathrm{NMR}$ spectrum of 9 in DMSO- $\mathrm{d}_{6}\left({ }^{13} \mathrm{C}: 200 \mathrm{MHz}\right)$, illustrating important methyl peaks

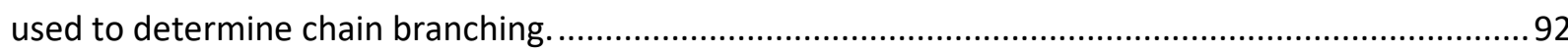

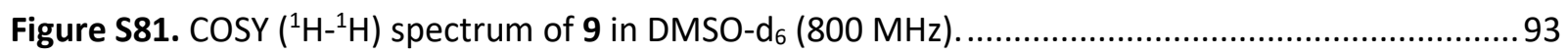

Figure S82. $\mathrm{HSQC}\left({ }^{1} \mathrm{H}_{-}{ }^{13} \mathrm{C}\right)$ spectrum of 9 in DMSO- $\mathrm{d}_{6}$. Red contours represent $\mathrm{CH}$ and $\mathrm{CH}_{3}$ groups, blue

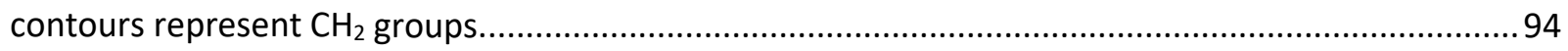

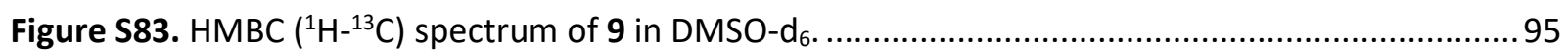

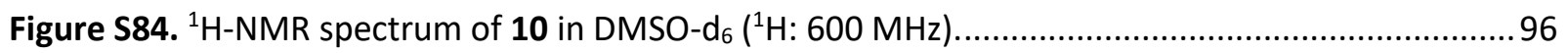

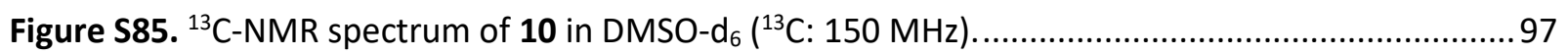

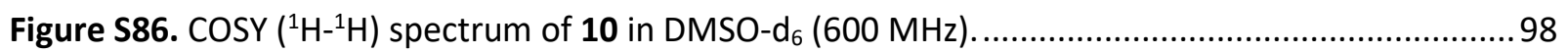

Figure S87. $\mathrm{HSQC}\left({ }^{1} \mathrm{H}_{-}{ }^{13} \mathrm{C}\right)$ spectrum of 10 in DMSO- $\mathrm{d}_{6}$. Blue contours represent $\mathrm{CH}$ and $\mathrm{CH}_{3}$ groups,

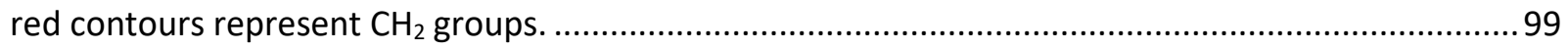

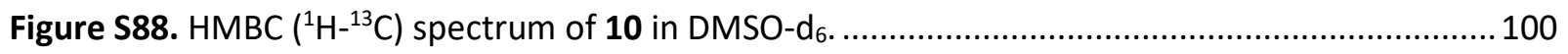

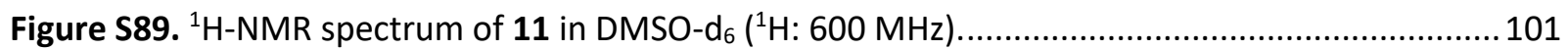

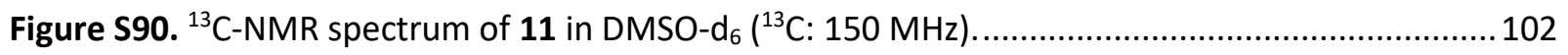

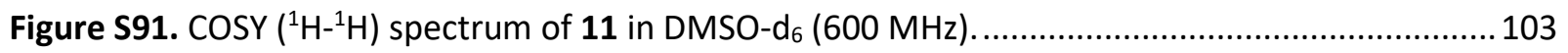

Figure S92. $\mathrm{HSQC}\left({ }^{1} \mathrm{H}_{-}{ }^{13} \mathrm{C}\right)$ spectrum of $\mathbf{1 1}$ in DMSO- $\mathrm{d}_{6}$. Red contours represent $\mathrm{CH}$ and $\mathrm{CH}_{3}$ groups,

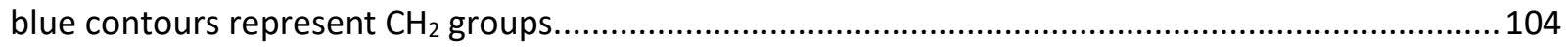

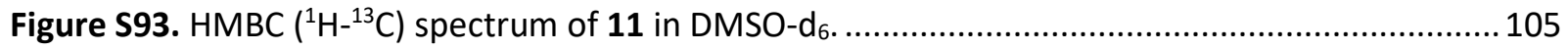

Figure S94. Activity of top 10 NPEs identified from cat-ELCCA screening for inhibiting pre-miR-21 processing by Dicer. \% inhibition at $75 \mathrm{~g} / \mathrm{mL}$ is shown. For all assays, pre-let-7d was used as a control to determine selectivity. (A) HTS data. (B) Tabulated \% inhibitions. Surfactin-producing strain $\mathbf{8 2 3 7 9}$ is

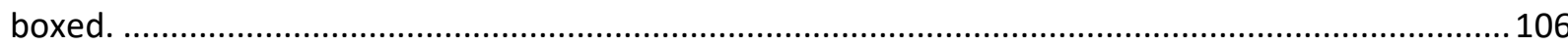

Figure S95. Direct binding of surfactins 3-6 (A-D) to pre-miR-21 measured via SPR. ..................... 107

Figure S96. Direct binding of surfactins 3-6 (A-D) to pre-let-7d measured via SPR. ….................. 107

Figure S97. Electrophoretic mobility shift assay (EMSA) analysis of pre-miR-21 binding to Dicer in the presence of surfactin 6. Surfactin 6 was tested from 10-120 $\mu \mathrm{M}$. Control Lane $1=$ pre-miR-21 + Dicer + buffer. Control Lane 2 = pre-miR-21 + Dicer + DMSO. Control Lane 3 = pre-miR-21 + buffer. Control Lane 4 = pre-miR-21 + DMSO.. 108

Figure S98. Single concentration $(200 \mu \mathrm{M})$ comparative analysis of compounds 1-11 inhibiting premiR-21 maturation. 108

Figure S99. Single concentration $(200 \mu \mathrm{M})$ comparative analysis of compounds 1-11 inhibiting pre-let$7 d$ maturation.

Figure S100. Impact of surfactin $6(100 \mu \mathrm{M})$ on HeLa cell growth. TritonX-100 was used as a control compound due to its role as a detergent-based membrane disruptor. (A) Cell viability as measured using the CellTiter Glo assay. (B) Cell cytotoxicity as measured using the CellTox Green assay..........109 
Figure S101. Activity of crude fractions from C18 reverse-phase flash chromatography in the catELCCA, illustrating fraction 7 (F7) as the fraction of interest..... 110

\section{SI Materials and Methods}

\subsection{General Experimental Procedures}

NMR spectra were collected using an Agilent $600 \mathrm{NMR}$ spectrometer $\left({ }^{1} \mathrm{H}: 600 \mathrm{MHz}, 13 \mathrm{C}: 150 \mathrm{MHz}\right)$ equipped with a $5 \mathrm{~mm}$ DB AUTOX PFG broadband probe and a Varian NMR System console, or a Bruker 800 NMR spectrometer $\left.\left({ }^{1} \mathrm{H}: 800 \mathrm{MHz}\right),{ }^{13} \mathrm{C}: 200 \mathrm{MHz}\right)$ with an Ascend magnet, a Bruker NEO console and equipped with $5 \mathrm{~mm}$ Triple resonance inverse detection $\mathrm{TCl}$ cryoprobe with automatic tuning and matching. All data analysis was performed using MestReNova NMR software. All chemical shifts were referenced to residual solvent peaks [ ${ }^{1} \mathrm{H}$ (MeOD- $d_{4}$ ): $3.31 \mathrm{ppm}$; $\left.{ }^{13} \mathrm{C}\left(\mathrm{MeOD}-d_{6}\right): 49.0 \mathrm{ppm}\right]$.

LC-HRMS analysis of compounds 1-6 was performed using an Agilent LC-MS system composed of an Agilent 1290 Infinity II UHPLC coupled to an Agilent 6545 LC/Q-TOF-MS system operating in positive mode, monitoring a mass range of 100 to 1700 amu. Chromatography was performed using a Phenomenex Kinetex $5 \mu \mathrm{m}$ Phenyl-Hexyl $100 \AA ̊$ column $(100 \times 4.6 \mathrm{~mm})$. Compound elution was accomplished utilizing a gradient starting with a $1 \mathrm{~min}$ isocratic step consisting of $40 \% \mathrm{~A}$ (A: $95 \% \mathrm{H} 2 \mathrm{O} / \mathrm{MeCN}+0.1 \%$ formic acid) followed by a 9 min linear gradient elution to $95 \% \mathrm{~B}(100 \%$ $\mathrm{MeCN}+0.1 \%$ formic acid), followed by an isocratic plateau step consisting of $95 \%$ B for 5 min (flow rate of $\left.0.4 \mathrm{mLmin}^{-1}\right)$. The divert valve was set to waste for the first $1 \mathrm{~min}$. Samples were injected at a concentration of $100 \mu \mathrm{gmL}^{-1}(3 \mu \mathrm{L})$, elution was detected by ESI-MS, and UV 195-400 $\mathrm{nm}$. All reagents were purchased from commercial sources and used without further purification. All solvents used for compound purification were HPLC grade or better unless otherwise stated. Maintenance and propagation of cultures was performed using standard media and protocols. ${ }^{1,2}$

\subsection{Natural product extract library}

The NPE library at the University of Michigan Center for Chemical Genomics contains 30,000 extracts derived from terrestrial and marine microorganisms collected from various locations throughout the world, including but not limited to, Costa Rica, Panama and Papua New Guinea. Samples include those from isolated monoculture microbes $(n=19,055)$, and those derived from field-collected biomass ('macrosamples,' $n=800$ ). Previous literature describes how these extracts were prepared. ${ }^{1,2}$

\section{3 cat-ELCCA}

NPE library screening, follow-up screening and testing of purified NPs was conducted using catELCCA as previously described (Lorenz, D. A.; Vander Roest, S.; Larsen, M. J.; Garner, A. L. "Development and Implementation of an HTS-Compatible Assay for the Discovery of Selective Small Molecule Ligands for pre-microRNAs." SLAS Discovery 2018, 23, 47-54; Garner, A. L.; Lorenz, D. A.; Gallagher, E. E. "A Click Chemistry Assay to Identify Natural Product Ligands for premicroRNAs." Methods Enzymol. 2019, 623, 85-99.).

\subsection{Strain Maintenance and Fermentation.}

Streptomyces sp. 82379-N6R was isolated from marine sediments collected from Hermosa Beach Costa Rica (protected area: $9^{\circ} 52^{\prime} 30.6^{\prime \prime} \mathrm{N},-83^{\circ} 18^{\prime} 05.5^{\prime \prime} \mathrm{W}$ ). A $500 \mathrm{mg}$ sample of wet sediment was diluted in $10 \mathrm{~mL}$ of sterile water and vortexed for $10 \mathrm{~min}$. Then, $1 \mathrm{~mL}$ of this suspension was applied directly to the top of the discontinuous sucrose gradient and centrifuged for 30 min at 
$300 \mathrm{~g}{ }^{3}$ From this suspension, $500 \mu \mathrm{L}$ aliquots of the $20 \%, 30 \%$, and $40 \%$ layers were then plated onto HVA agar ${ }^{4}$ supplemented with chlortetracycline $\left(10 \mu \mathrm{gmL}^{-1}\right)$, cycloheximide $\left(25 \mu \mathrm{gmL}^{-1}\right)$ and nalidixic acid $\left(25 \mu \mathrm{gmL}^{-1}\right)$. The plates were then incubated at $28^{\circ} \mathrm{C}$ for 1 month. Single colonies were picked off plates and re-streaked repetitively onto oatmeal agar until pure monocultures were obtained. Spore stocks were stored at $-80^{\circ} \mathrm{C}$ in $20 \%(\mathrm{v} / \mathrm{v})$ glycerol solution.

For the purposes of fermentation, S. sp. 82379-N6R was maintained on oatmeal agar (6\% oatmeal, $1.25 \%$ agar and $3 \% \mathrm{NaCl}$ ). ${ }^{2}$ Plates were grown at $28{ }^{\circ} \mathrm{C}$ for 1 week (or until obvious sporulation had occurred). Seed cultures were grown in $14 \mathrm{~mL}$ dual-position cap tubes containing $3 \mathrm{~mL}(20 \mathrm{x})$ of ISP2 media ( $1 \%$ malt extract, $0.4 \%$ yeast extract, $0.4 \%$ dextrose and $3 \% \mathrm{NaCl}$ ) were inoculated with a loop-full of vegetative cells from an oatmeal plate culture of Streptomyces sp. $82379-N 6 R$ and incubated on a rotary shaker (200 r.p.m.) at $28^{\circ} \mathrm{C}$ for 5 days. Following incubation, the $3 \mathrm{~mL}$ seed cultures $(20 \mathrm{x})$ were combined and centrifuged to reduce heterogeneity. Seed culture $(3 \mathrm{~mL})$ was poured into a $250-\mathrm{mL}$ baffled flask containing $100 \mathrm{~mL}$ of ISP2 $(20 \mathrm{x})$ and grown for 7 days on a rotary shaker at 200 r.p.m. The new $100 \mathrm{~mL}$ seed cultures were again combined and centrifuged to reduce heterogeneity and $100 \mathrm{~mL}$ was transferred into a $2.8 \mathrm{~L}$ baffled Fernbach flask containing $1.2 \mathrm{~L}(20 \mathrm{x})$ of A3M media ( $0.5 \%$ glucose, $2 \%$ glycerol, $0.5 \%$ soluble starch, $0.2 \%$ pharma-media, and $0.3 \%$ yeast extract) and fermentation was carried out for 9 days total on a rotary shaker at 200 r.p.m. On day 2 of growth, a $12 \mathrm{~mL}$ rhodococcus spike was added to each 2.8 $\mathrm{L}$ flask. Then, on day 3 of incubation, $22 \mathrm{~g}$ of Amberlite XAD16 resin contained within a polypropylene mesh bag was added to each $1.2 \mathrm{~L}$ culture and incubated for the final 7 days on the rotary shaker at 200 r.p.m. On day 9 the resin bags were removed and washed with copious amounts of $\mathrm{H}_{2} \mathrm{O}$ to remove any water-soluble media components. The washed resin bags were then placed into $500 \mathrm{~mL}$ of $\mathrm{MeOH}$, followed by $500 \mathrm{~mL}$ of acetone and $500 \mathrm{~mL}$ of ethyl acetate (EtOAc). The organic fractions were combined and dried in vacuo, then reconstituted with minimal methanol ( $50 \mathrm{~mL}$ ). The solution was filtered through glass wool and the filtrate was loaded onto C18 resin and dried extensively prior to C18 fractionation.

Streptomyces sp. R312_4 was isolated from soil sediments collected from Israel at the City of David, site 5 ( $\left.31^{\circ} 76^{\prime} 30^{\prime \prime} \mathrm{N}, 35^{\circ} 24^{\prime} 15^{\prime \prime} \mathrm{E}\right)$. A $200 \mathrm{mg}$ sample of dry sediment was diluted in $1 \mathrm{~mL}$ of sterile water and was briefly vortexed. This was then serially diluted into sterile water to produce four dilutions from $1 / 10$ to $1 / 1000$. These were then plated onto R2YE supplemented with nalidixic acid $\left(25 \mu \mathrm{g} \mathrm{m}^{-1}\right)$ and benomyl $\left(10 \mu \mathrm{g} \mathrm{mL}^{-1}\right)$. These were grown at $28^{\circ} \mathrm{C}$ for 2 weeks. Single colonies were picked off the plate until monocultures were obtained.

For the purposes of fermentation, S. sp. R312_4 was maintained on R2YE media. Plates were grown at $28{ }^{\circ} \mathrm{C}$ for 1 week (or until obvious sporulation had occurred). Seed cultures in a $250 \mathrm{~mL}$ baffled flask containing $100 \mathrm{~mL}$ of TSB media were inoculated with a $1 \times 1 \mathrm{~cm}^{2}$ area of cells via an inoculating loop and incubated on a rotary shaker $\left(200\right.$ r.p.m.) at $28^{\circ} \mathrm{C}$ for 3 days. Following incubation, $30 \mathrm{~mL}$ was transferred to $2.8 \mathrm{~L}$ baffled Fernbach flask containing $1 \mathrm{~L}$ of TSB and fermentation carried out for 7 days at $28{ }^{\circ} \mathrm{C}$ on a rotary shaker at 200 r.p.m. On day 7 the culture was pelleted via centrifugation at $6,000 \mathrm{x} g$ for $30 \mathrm{~min}$. To the supernatant was added $20 \mathrm{~g}$ of activated XAD16 resin (washed successively with water, methanol, acetone, and water) and incubated with gentle agitation overnight. Simultaneously, the cells were placed into $500 \mathrm{~mL}$ of methanol and incubated overnight. The cell extract was subsequently filtered and dried in vacuo. The resin was subsequently filtered out, placed in a $1 \mathrm{~L}$ beaker and incubated with methanol $(2 \mathrm{x}$ $400 \mathrm{~mL}$ ). The organic fractions were combined and dried in vacuo, then reconstituted with minimal methanol ( $50 \mathrm{~mL}$ ). The solution was filtered through glass wool and the filtrate was loaded onto C18 resin and dried extensively prior to $\mathrm{C} 18$ fractionation. 
Paenibacillus sp. PAP203 was isolated from soil collected on the campus of Eastern Michigan University as part of the Tiny Earth Educational Program (Hurley et al., 2021 - in press). Paenibacillus sp. PAP203 was grown on ASM agar plates [0.5 g/L dextrose, $0.5 \mathrm{~g} / \mathrm{L}$ peptone, $0.5 \mathrm{~g} / \mathrm{L}$ yeast extract, $0.5 \mathrm{~g} / \mathrm{L}$ tryptone, 0.5 $\mathrm{mM} \mathrm{KH}_{2} \mathrm{PO}_{4}(\mathrm{pH} 7.0), 0.25 \mathrm{mM} \mathrm{MgSO}_{4}, 0.25 \mathrm{mM} \mathrm{CaCl} \cdot 2 \mathrm{H}_{2} \mathrm{O}, 1 \mathrm{~mL} / \mathrm{L}$ of a minor salts solution $(1000 \times$ minor salts [per liter] $=9.5 \mathrm{~g} \mathrm{Na}_{2}-\mathrm{EDTA} \cdot 2 \mathrm{H}_{2} \mathrm{O}, 7 \mathrm{~g} \mathrm{FeSO} \cdot 7 \mathrm{H}_{2} \mathrm{O}, 1 \mathrm{~g} \mathrm{H}_{3} \mathrm{BO}_{3}, 250 \mathrm{mg} \mathrm{MnSO}{ }_{4} \cdot \mathrm{H}_{2} \mathrm{O}, 50 \mathrm{mg} \mathrm{ZnSO} \cdot 7 \mathrm{H}_{2} \mathrm{O}$, $50 \mathrm{mg} \mathrm{Na} 2 \mathrm{MoO}_{4} \cdot 2 \mathrm{H}_{2} \mathrm{O}, 50 \mathrm{mg} \mathrm{CuSO}$, and $10 \mathrm{mg} \mathrm{CoCl}$ ), $100 \mu \mathrm{g} / \mathrm{mL}$ D-alanine, and $12 \mathrm{~g} / \mathrm{L}$ agar] together with a D-alanine auxotrophic mutant of Escherichia coli (Dorandish et al., 2021 - in review). Culture tubes containing $10 \mathrm{~mL}$ of TYME-D medium $[0.5 \mathrm{~g} / \mathrm{L}$ peptone, $0.5 \mathrm{~g} / \mathrm{L}$ yeast extract, $0.5 \mathrm{~g} / \mathrm{L}$ tryptone, $0.5 \mathrm{mM}$ $\mathrm{KH}_{2} \mathrm{PO}_{4}(\mathrm{pH} 7.0), 0.25 \mathrm{mM} \mathrm{MgSO}_{4}, 0.25 \mathrm{mM} \mathrm{CaCl}_{2} \cdot 2 \mathrm{H}_{2} \mathrm{O}$, and $1 \mathrm{ml} / \mathrm{L}$ of the minor salts solution] were then inoculated with Paenibacillus sp. PAP203 colonies that yielded a zone of inhibition in the $E$. coli and grown for 3 days at $300 \mathrm{rpm}$ at $30^{\circ} \mathrm{C}$. Finally, $10 \mathrm{~mL}$ of culture were transferred to $1 \mathrm{~L}$ of EARM media [5 g/l arrowroot starch (Bob's Red Mill, Milwaukie, OR, USA), $0.5 \mathrm{~g} / \mathrm{l}$ peptone, $0.5 \mathrm{~g} / \mathrm{l}$ yeast extract, $0.5 \mathrm{~g} / \mathrm{l}$ tryptone, $0.5 \mathrm{mM} \mathrm{KH}_{2} \mathrm{PO}_{4}(\mathrm{pH} 7.0), 0.25 \mathrm{mM} \mathrm{MgSO}_{4}, 0.25 \mathrm{mM} \mathrm{CaCl}_{2} \cdot 2 \mathrm{H}_{2} \mathrm{O}$, and $1 \mathrm{~mL} / \mathrm{L}$ of the minor salts solution] in a $2800-\mathrm{mL}$ fernbach flask (no baffles) and grown for 7 days at $200 \mathrm{rpm}$ at room temperature $\left(\sim 22^{\circ} \mathrm{C}\right)$. On day four, $20 \mathrm{~g}$ of sterilized Amberlite XAD $16 \mathrm{~N}$ resin sealed in a semi-porous membrane was added to each flask. On day 7, the Amberlite XAD16N resin was extracted with $200 \mathrm{~mL}$ of 1:1 methanol:ethyl acetate mixture and dried in a RotoVap.

\subsection{Mass spectrometry analysis (MSMS for Molecular Networking)}

Aliquots $(1 \mu \mathrm{L})$ of the crude extracts $\left(1 \mathrm{mgmL}^{-1}\right.$ in $\left.\mathrm{MeOH}\right)$ of $82379-\mathrm{N} 6 \mathrm{R}$, Streptomyces sp. R312_4, Paenibacillus sp. PAP203, and A3M medium blank were analysed using an Agilent LC-MS system composed of an Agilent 1290 Infinity II UHPLC coupled to an Agilent 6545 ESI-Q-TOF-MS operating in positive mode. A Kinetex phenyl-hexyl $1.7 \mu \mathrm{m}, 2.1 \times 50 \mathrm{~mm}$ column was utilised with $1 \mathrm{~min}$ isocratic elution of $90 \% \mathrm{~A}(\mathrm{~A}: 95 \% \mathrm{H} 2 \mathrm{O} / \mathrm{MeCN}+0.1 \%$ formic acid) followed by 6 min linear gradient elution to $100 \% \mathrm{~B}\left(100 \% \mathrm{MeCN}+0.1 \%\right.$ formic acid) with a flow rate of $0.4 \mathrm{mLmin}^{-1}$.

ESI conditions were set with the capillary temperature at $320^{\circ} \mathrm{C}$, source voltage at $3.5 \mathrm{kV}$, and a sheath gas flow rate of $11 \mathrm{~L} / \mathrm{min}$. The divert valve was set to waste for the first $1 \mathrm{~min}$. Ions detected in the full scan at an intensity above 1000 counts at 3 scans/s, with an isolation width of $1.3 \sim \mathrm{m} / \mathrm{z}$, a maximum of two selected precursors per cycle, and using three fixed collision energies $(10,20$, and $40 \mathrm{eV})$. Purine $\mathrm{C}_{5} \mathrm{H}_{4} \mathrm{~N}_{4}[\mathrm{M}+\mathrm{H}]^{+}$ion $(\mathrm{m} / \mathrm{z} 121.050873)$ and hexakis $(1 \mathrm{H}, 1 \mathrm{H}, 3 \mathrm{H}$-tetrafluoropropoxy)-phosphazene $\mathrm{C}_{18} \mathrm{H}_{18} \mathrm{~F}_{24} \mathrm{~N}_{3} \mathrm{O}_{6} \mathrm{P}_{3}[\mathrm{M}+\mathrm{H}]^{+}$ion $(\mathrm{m} / \mathrm{z} 922.009798)$ were used as internal lock masses.

The acquired MS/MS data were converted from Agilent MassHunter data files (.d) to mzXML file format using MSConvert software ${ }^{5}$, part of the ProteoWizard package and transferred to the Global Natural Products Social Molecular Networking (GNPS) server (gnps.ucsd.edu).

\subsection{Molecular Networking}

A Molecular network was created using the GNPS data analysis workflow. ${ }^{6}$ The data was filtered by removing all MS/MS fragment ions within +/- $17 \mathrm{Da}$ of the precursor $\mathrm{m} / \mathrm{z}$. MS/MS spectra were window filtered by choosing only the top 6 fragment ions in the +/-50Da window throughout the spectrum. The precursor ion mass tolerance was set to $0.05 \mathrm{Da}$ and a MS/MS fragment ion tolerance of $0.05 \mathrm{Da}$. A network was then created where edges were filtered to have a cosine score above 0.7 and more than 6 matched peaks. Further, edges between two nodes were kept in the network if and only if each of the nodes appeared in each other's respective top 10 most similar nodes. Finally, the maximum size of a molecular family was set to 100 , and the lowest scoring edges were removed from molecular families until the molecular family size was below this threshold. The spectra in the network were then searched against GNPS' spectral libraries. 
The library spectra were filtered in the same manner as the input data. All matches kept between network spectra and library spectra were required to have a score above 0.7 and at least 6 matched peaks. The resulting spectral network was imported into Cytoscape (version 3.5.1) ${ }^{7}$, where nodes corresponding to media components and solvent were subtracted. Remaining nodes represented parent $(+) \mathrm{m} / \mathrm{z}$ of metabolites detected in analysed extracts, with node size indicating metabolite abundance and edge thickness corresponding to cosine scores (Figures S1 and S2)

\subsection{Purification (Compounds 1-6)}

Flash chromatography was performed using an Isolera One (Biotage ${ }^{\circledR}$ ) utilizing a pre-packed SiliCycle ${ }^{\circledR}$ reversed-phase C18 column (40 g). Material was eluted with a flow rate of $50 \mathrm{mLmin}^{-1}$ collecting $120 \mathrm{~mL}$ fractions. Material was eluted using a 3-solvent gradient system, consisting of $\mathrm{H}_{2} \mathrm{O}$ (solvent A), methanol (solvent $\mathrm{B}$ ) and acetonitrile (solvent $\mathrm{C}$ ). The column was first washed with $10 \%$ methanol in $\mathrm{H}_{2} \mathrm{O}$ for $1 \mathrm{CV}$, followed by a linear increasing gradient from $10 \%$ to $100 \%$ methanol over $12 \mathrm{CV}$. An isocratic gradient of $100 \%$ methanol was then applied for $5 \mathrm{CV}$, followed finally by an additional isocratic gradient of $100 \%$ acetonitrile for $5 \mathrm{CV}$. Fractions were dried into pre-weighed vials using a V10-touch evaporator (Biotage ${ }^{\circledR}$ ) coupled with a Gilson GX-271 Liquid Handler. The individual fractions were sent for bioactivity assessment, which identified fraction 7 (F7) as possessing the majority of activity.

\subsection{Purification (Compounds 7-9)}

Flash chromatography was performed using an automated chromatography system (Isolera Selekt, Biotage ${ }^{\circledast}$ ) utilizing a pre-packed Phenomenex ${ }^{\circledR}$ reversed-phase C18 column (10 g). Material was eluted with a flow rate of $20 \mathrm{mLmin}^{-1}$ collecting $68 \mathrm{~mL}$ fractions. Material was eluted using a 3-solvent step gradient system, consisting of $\mathrm{H}_{2} \mathrm{O}$ (solvent $A$ ), methanol (solvent $B$ ) and acetonitrile (solvent $\mathrm{C}$ ). The column was first washed with $10 \%$ methanol in $\mathrm{H}_{2} \mathrm{O}$ for $3 \mathrm{CV}$, followed by a 4 step gradient consisting of $10 \%, 40 \%, 70 \%$ and $100 \%$ methanol in water, each run for 4 column volumes followed by an additional isocratic gradient of $100 \%$ acetonitrile for 4 column volumes. Fractions were dried into pre-weighed vials using a V10-touch evaporator (Biotage ${ }^{\circledR}$ ) coupled with a Gilson GX-271 Liquid Handler. The individual fractions were then screened by MS/MS (see mass spectrometry analysis for details) indicating the production of surfactin like molecules of interest in both F4 and the cell extract. These were combined and subjected to further HPLC purification.

\subsection{HPLC Purification (Compounds 10-11)}

The crude extract of Paenibacillus sp. PAP203 (200 mg) was dissolved in HPLC grade MeOH (1 mL) and subjected to chromatographic fractionation using preparative reversed phase HPLC (Phenomenex kinetex $\mathrm{C}_{18} 100 \AA$, $21.2 \times 250 \mathrm{~mm} .5 \mu \mathrm{m}, 30 \mathrm{~mL} / \mathrm{min}$, isocratic elution with $90 \% \mathrm{H}_{2} \mathrm{O} / \mathrm{MeCN}$ for 2 minutes followed by gradient elution from $90 \% \mathrm{H}_{2} \mathrm{O} / \mathrm{MeCN}$ to $100 \% \mathrm{MeCN}$ over 30 min including $0.01 \%$ TFA as modifier) to yield 18 fractions. Fractions 9 and 10 were combined based on similar UV profiles.

Final purification of F9-10 (58 mg) was subjected to chromatographic purification using a semipreparative reversed-phase HPLC (Zorbax Eclipse XDB- $C_{8}, 9.4 \times 250 \mathrm{~mm}, 5 \mu \mathrm{m}, 4 \mathrm{~mL} / \mathrm{min}$, isocratic elution with $75 \% \mathrm{H}_{2} \mathrm{O} / \mathrm{MeCN}$ for 3 minutes followed by gradient elution from $75 \% \mathrm{H}_{2} \mathrm{O} / \mathrm{MeCN}$ to $50 \% \mathrm{H}_{2} \mathrm{O} / \mathrm{MeCN}$ over 40 min including $0.01 \%$ TFA as modifier) to yield pure compounds fusaricidin A (10) $(6.2 \mathrm{mg})$ and fusaricidin $B(\mathbf{1 1})(5.7 \mathrm{mg})$

\subsection{HPLC Purification (Compounds 1-6)}

Initial fractionation of metabolites from F7 was accomplished utilizing preparative HPLC (Shimadzu LC-20AT), using a reversed-phase Phenomenex Kinetex 5 um C18 $100 \AA$ Å column (250× 
$21.2 \mathrm{~mm}$ ) run at a flow rate of $9 \mathrm{mLmin}^{-1}$. Compound elution was monitored using a Shimadzu diode array detector (SPD-M20A) monitoring specifically at 195 and $200 \mathrm{~nm}$. Samples were brought up in HPLC grade $\mathrm{MeOH}\left(\sim 100 \mathrm{mgmL}^{-1}\right.$ ), and injected in $500 \mu \mathrm{L}$ to $1 \mathrm{~mL}$ aliquots (using a 1 $\mathrm{mL}$ loop). Elution was accomplished using an isocratic gradient of $23 \% \mathrm{H}_{2} \mathrm{O}+0.1 \%$ formic acid (solvent A) and 77\% acetonitrile (solvent B) over $140 \mathrm{~min}$. Fractions were collected based on similar UV profiles between peaks, yielding eight fractions in total F7.0 - F7.7 eluting between 40 and $120 \mathrm{~min}$. Masses of each fraction from a combined $72 \mathrm{~L}$ fermentation $(3 \times 24 \mathrm{~L})$ were determined: F7.0 (15.6 mg), F7.1 (25.2 mg), F7.2 (18.8 mg), F7.3 (53 .1 mg), F7.4 (74.8 mg), F7.5 (6.4 mg), F7.6 (126.4 mg), and F7.7 (7.3 mg). Fractions F7.0-F7.4 and F7.6 were subjected to further HPLC purification.

Final purification of F7.0-F7.4 and F7.6 was accomplished utilizing preparative HPLC (Shimadzu LC-20AT), using a reversed-phase Phenomenex Luna $5 \mu \mathrm{m}$ Phenyl-Hexyl $100 \AA ̊$ column $(250 \times 10.00$ $\mathrm{mm}$ ) run at a flow rate of $4 \mathrm{~mL} / \mathrm{min}$. Compound elution was monitored using a Shimadzu diode array detector (SPD-M20A) monitoring specifically at 195 and $200 \mathrm{~nm}$. Samples were brought up in HPLC grade $\mathrm{MeOH}$ ( $100 \mathrm{mgmL}-1$ ), and injected in $100 \mu \mathrm{L}$ aliquots (using a $200 \mu \mathrm{L}$ loop). In all cases, elution was accomplished using a linear increasing gradient consisting of $\mathrm{H}_{2} \mathrm{O}+0.1 \%$ formic acid (solvent $A$ ) and acetonitrile (solvent $B$ ). The gradient was started at $65 \%$ solvent $B$, increasing to $70 \%$ solvent $B$ over $40 \mathrm{~min}$. The column was then re-equilibrated with a isocratic gradient of $65 \%$ acetonitrile for an additional $10 \mathrm{~min}$ (50 min total). This yielded pure compounds 1-6 from F7.0 (1, 1.6 mg), F7.1 (2, 6.8 mg), F7.2 (3, $2.7 \mathrm{mg})$, F7.3 (4, 11.4 mg), F7.4 (5, $26.2 \mathrm{mg})$ and F7.6 (6, $44.1 \mathrm{mg})$.

\subsection{HPLC Purification (Compounds 7-9)}

Initial fractionation of metabolites from F4/Cell Extract was accomplished utilizing preparative HPLC (Shimadzu LC-20AT), using a reversed-phase Phenomenex Luna $5 \mu \mathrm{m} \mathrm{C18}(250 \times 21.2 \mathrm{~mm})$ run at a flow rate of $4 \mathrm{mLmin}^{-1}$. Compound elution was monitored using a Shimadzu diode array detector (SPD-M20A) monitoring specifically at 195 and $200 \mathrm{~nm}$. Samples were brought up in HPLC grade $\mathrm{MeOH}\left(\sim 50 \mathrm{mgmL}^{-1}\right.$ ) and injected in $100 \mathrm{uL}$ aliquots (using a $500 \mathrm{uL}$ loop). Elution was accomplished using a twostep, isocratic gradient of first $52 \% \mathrm{H}_{2} \mathrm{O}+0.1 \%$ formic acid (solvent $\mathrm{A}$ ) and $48 \%$ acetonitrile (solvent $\mathrm{B}$ ) over $20 \mathrm{~min}$, then switching to $22 \% \mathrm{H}_{2} \mathrm{O}+0.1 \%$ formic acid (solvent A) and $78 \%$ acetonitrile (solvent B) over another $65 \mathrm{~min}$. Fractions were collected based on similar UV profiles between peaks, yielding eight fractions in total F4.1 - F4.8, with the first two fractions eluting in the first step eluting between 10 and $12 \mathrm{~min}$, and Fractions F4.3 -4.8 eluting in the second step between 30 and $80 \mathrm{~min}$. Further LC/MS and NMR analysis led to the identification of another surfactin molecule (F4.8) as well as two mycosubtilin molecules (F4.1 and F4.2).

\subsection{Depsipetide Hydrolysis}

Due to poor fragmentation of the cyclized products, compounds 1-6 were subjected to base hydrolysis according to literature precedent. ${ }^{8}$ Approximately $0.5 \mathrm{mg}$ of 1-6 were treated with $1 \mathrm{~N}$ $\mathrm{KOH}(500 \mu \mathrm{L})$ at room temperature for $2 \mathrm{~h}$. The reaction mixtures were diluted by adding a $5 \mathrm{~mL}$ of a phosphate buffered saline solution $(\mathrm{pH}=7.4)$. The mixtures were then applied to Chromabond prepacked C18 SPE cartridges $(1 \mathrm{~g})$ washed with $25 \mathrm{~mL} \mathrm{H} \mathrm{H}_{2} \mathrm{O}$ to remove water soluble salts and impurities. Hydrolysed material was eluted with $100 \%$ methanol $(10 \mathrm{~mL})$ yielding crude samples of the linearized peptides (1a-6a). These solutions were dried in vacuo, weighed, and reconstituted in methanol to a concentration of $\sim 250 \mathrm{\mu gmL}^{-1}$. These mixtures were used for MSMS analysis without further purification. 


\subsection{MSMS Analysis for Compound Fragmentation}

LC-MSMS analysis of hydrolyzed compounds 1a-6a was performed using an Agilent a 6545 LC/QTOF system operating in positive mode, monitoring a mass range of 200 to $1200 \mathrm{amu}$. Chromatography was performed using a Phenomenex Kinetex $5 \mu \mathrm{m}$ Phenyl-Hexyl $100 \AA$ column $(100 \times 4.6 \mathrm{~mm})$. Compound elution was accomplished using the same gradient utilized for LC-MS analysis of compounds 1-6. Crude samples were injected at a concentration of $250 \mu \mathrm{gmL}^{-1}(5 \mu \mathrm{L})$, elution was detected by ESI-MS, and UV 195-400 nm. ESI conditions were set with the capillary temperature at $320^{\circ} \mathrm{C}$, source voltage at $3.5 \mathrm{kV}$, and a sheath gas flow rate of $11 \mathrm{Lmin}^{-1}$. The divert valve was set to waste for the first $1 \mathrm{~min}$. Ions of interest, in each case corresponded to the [M + $\mathrm{H}]^{+},[\mathrm{M}+\mathrm{Na}]^{+}$and the $[\mathrm{M}+\mathrm{K}]^{+}$of each hydrolysed analogues, were selectively targeted (see Table $\mathrm{SX}$ for a full list of targeted masses) within a retention time window $(\Delta \pm 0.5 \mathrm{~min})$ around the peak retention time as determined by UV analysis (195 $\mathrm{nm}$ ). Fragmentation was accomplished with an isolation width of $1.3 \sim \mathrm{m} / \mathrm{z}$ and using a fixed collision energy of either 15 or $30 \mathrm{eV}$.

\subsection{SPR}

Direct binding to pre-miR-21 and pre-let-7d was conducted via SPR as previously described by our group (Garner, A. L.; Lorenz, D. A.; Gallagher, E. E. "A Click Chemistry Assay to Identify Natural Product Ligands for pre-microRNAs." Methods Enzymol. 2019, 623, 85-99; Garner, A. L.; Lorenz, D. A.; Sandoval, J.; Gallagher, E. E.; Kerk, S. A.; Kaur, T.; Menon, A. "Tetracyclines as Inhibitors of pre-microRNA Maturation: A Disconnection Between RNA Binding and Inhibition." ACS Med. Chem. Lett. 2019, 10, 816-821.). 9999

\subsection{EMSA}

EMSA conditions were adapted from those previously reported for Dicer. ${ }^{10}$ Chemically synthesized 5' phosphorylated pre-miR-21 (Dharmacon) was dissolved in $100 \mathrm{mM}$ phosphate buffer (pH 8) and diluted to make a $50 \mathrm{mM}$ stock solution. The RNA was refolded by heating and snap-cooling prior to use. A 2X RNA Master Mix was then prepared as follows for the assay: $3.2 \mu \mathrm{L}$ of $50 \mathrm{mM}$ RNA, $1.6 \mu \mathrm{L}$ of $10 \% \mathrm{NP}-40,0.6 \mu \mathrm{L}$ of $1 \mathrm{M} \mathrm{DTT}$, and $74.6 \mu \mathrm{L}$ of ultrapure water. Human Dicer was expressed and purified as previously reported by our. ${ }^{9}$ Dicer was then diluted to a stock concentration of 1.6 $\mathrm{mg} / \mathrm{mL}$ in EMSA buffer (100 mM Tris (pH 7.6), $100 \mathrm{mM} \mathrm{NaCl}, 20 \%$ glycerol, $1 \mathrm{mM}$ EDTA). Binding was initiated by addition of 2 X RNA Master Mix $(5.0 \mu \mathrm{L})$ to Dicer stock $(10.0 \mu \mathrm{L})$ in the presence or absence of compound dissolved in DMSO $(5.0 \mu \mathrm{L})$. Samples were incubated at $4{ }^{\circ} \mathrm{C}$ for $40 \mathrm{~min}$ before addition of $10 \mathrm{uL}$ of loading dye. The samples were then loaded on a $5 \%$ TBE gel and run in 1X TBE buffer before being stained with SYBR Green II. Gels were then imaged on a gel imager.

\subsection{6 pmiRgLO Assay}

HeLa cells were transfected with 100 nanograms of various pmiRGLO contructs using Lipofectamine LTX with PLUS reagent (Invitrogen 15338100). $5 \mathrm{~h}$ after transfection, cells were treated with $100 \mu \mathrm{M}$ of surfactin or the corresponding amount of DMSO. $48 \mathrm{~h}$ after transfection, cells were analyzed using the Dual-Glo luciferase reagent (Promega E2920) according to the manufacturer's recommendation. pmirGLO vector was ordered from Promega, and miR-21, miR-21 mismatch and let-7d was cloned in with oligos recommended by Promega.

\subsection{Cell Viability Assay}

HeLa cells were transfected and treated as described for the pmiRGLO assay. The CellTiter-Glo assay kit was purchased from Promega and was performed according to the manufacturer's instructions. $48 \mathrm{~h}$ after transfection, the cell culture media was replaced with $100 \mu \mathrm{L}$ of OptiMEM and then lysed with $100 \mu \mathrm{L}$ of 
CellTiter-Glo reagent. Total luminescence was read within $1 \mathrm{~h}$ using a BioTek Cytation 3 reader. Data was processed in GraphPad Prism.

\subsection{Cytotoxicity Assay}

HeLa cells were transfected and treated as described for the pmiRGLO assay. CellTox Green cytotoxicity kit was purchased from Promega. $48 \mathrm{~h}$ after transfection, the cell culture media was replaced with a 1:1000 dilution of the CellTox Green reagent in OptiMEM. Fluorescence at was read at $485 / 528 \mathrm{~nm}$ within 20 min in a BioTek Cytation 3 reader. Data was processed in GraphPad. 

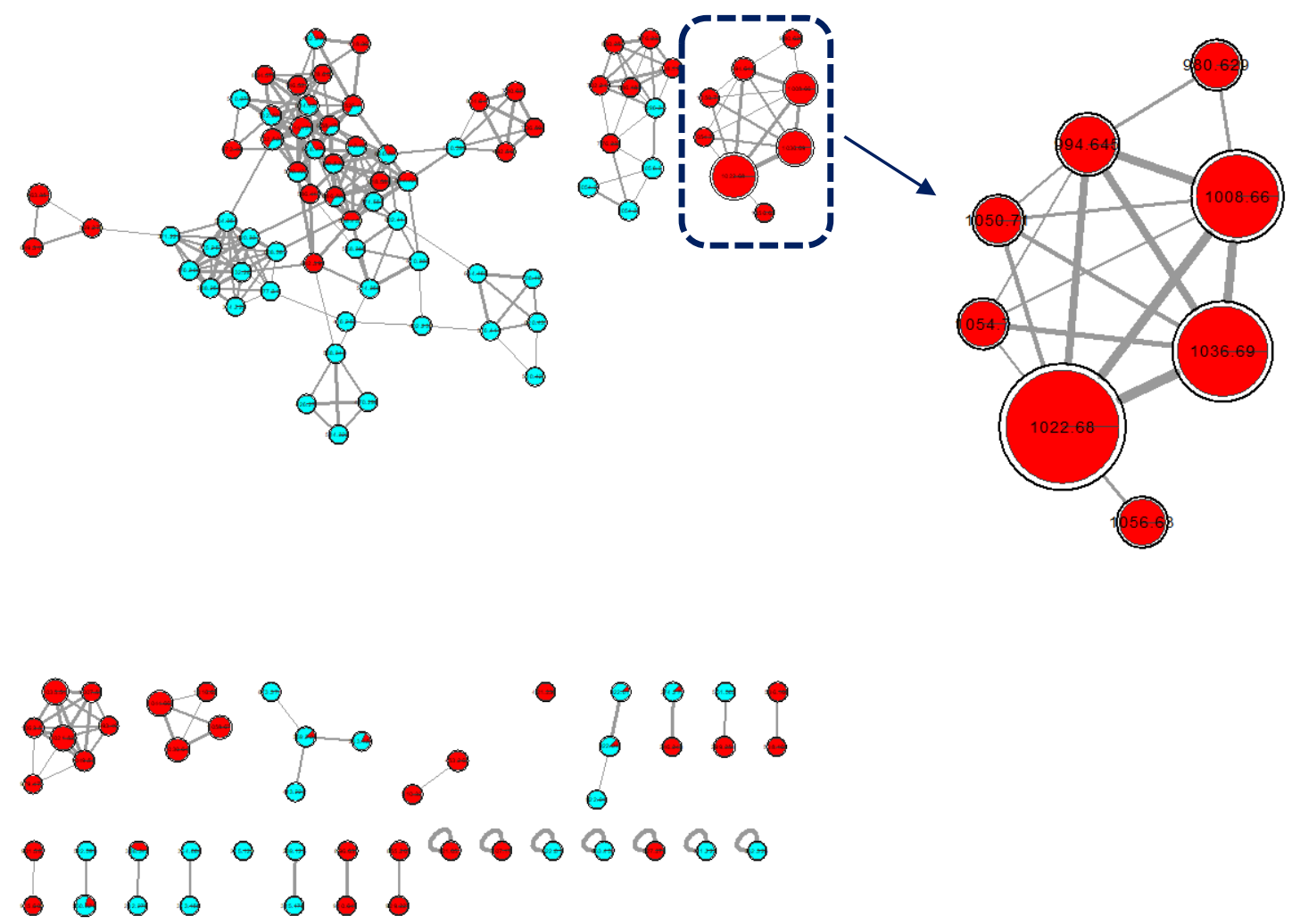

480808088888608

- $88 \theta 000800000$

- 800000000000

8080980000080

680800

Figure S1. Complete GNPS molecular network for surfactins detected in 82379-N6R crude extract. 82379$\mathrm{N} 6 \mathrm{R}$ red nodes, and $\mathrm{A} 3 \mathrm{M}$ medium blue nodes.

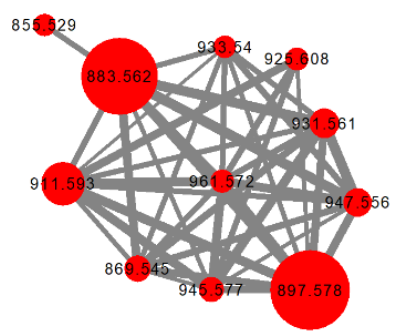

Figure S2. GNPS molecular network for fusaricidin family detected in Paenibacillus sp. PAP203 crude extract. 


\section{Purification}

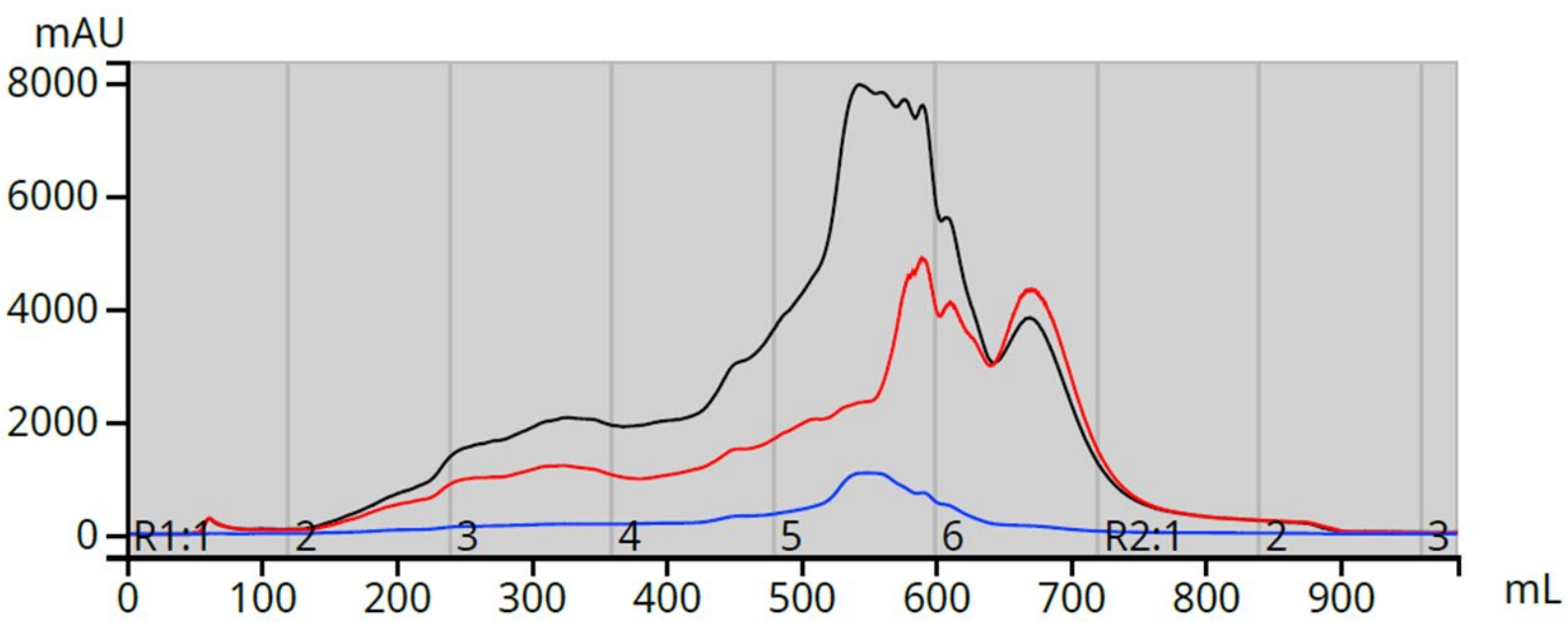

Figure S3. Initial Biotage fractionation of crude extract from sp. 82379-N6R. Solvent $\mathrm{A}_{\mathrm{H}} \mathrm{H}_{2} \mathrm{O}$; solvent $\mathrm{B}$ : $\mathrm{MeOH}$; solvent C: $\mathrm{ACN}$; $\mathrm{C} 18(40 \mathrm{~g})$, flow rate $40 \mathrm{mLmin}$. . Elution was monitored at $200 \mathrm{~nm}$ (red), $254 \mathrm{~nm}$ (blue), and $\lambda$-all (black, 198-400 $\mathrm{nm}$ ).

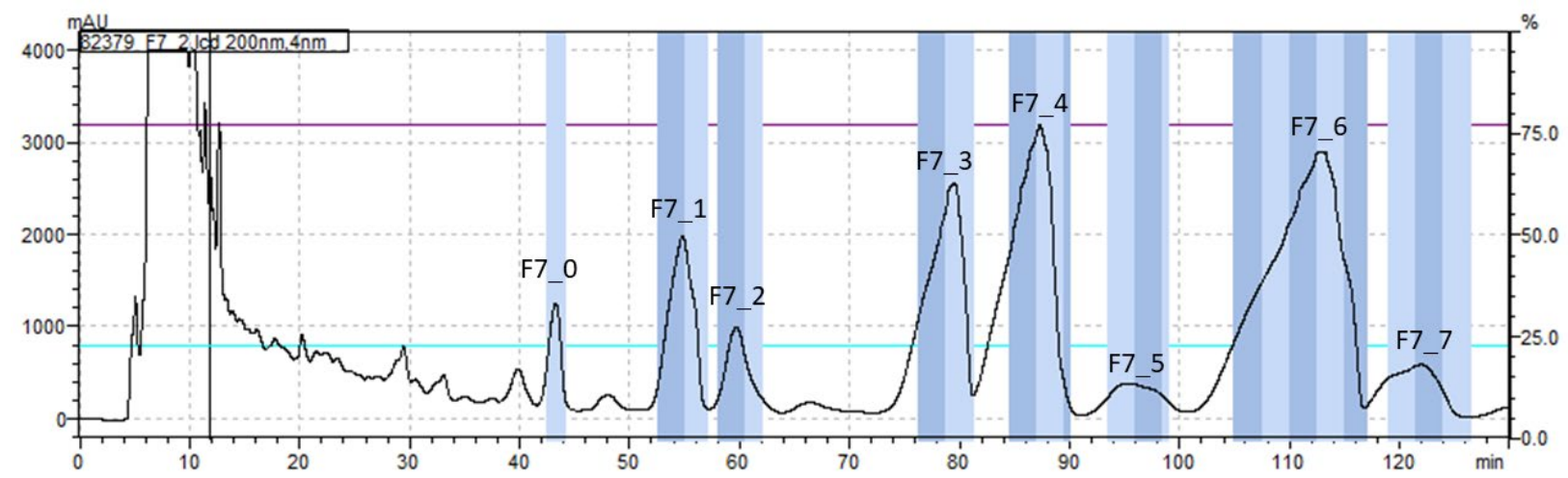

Figure S4. Initial HPLC fractionation of F7 (Figure S2) from Biotage cleanup. Solvent $A: \mathrm{H}_{2} \mathrm{O}+0.1 \%$ FA (33\%); solvent B: ACN (77\%); C18 $(250 \times 21.2)$ flow rate $9 \mathrm{mLmin}^{-1}$. 

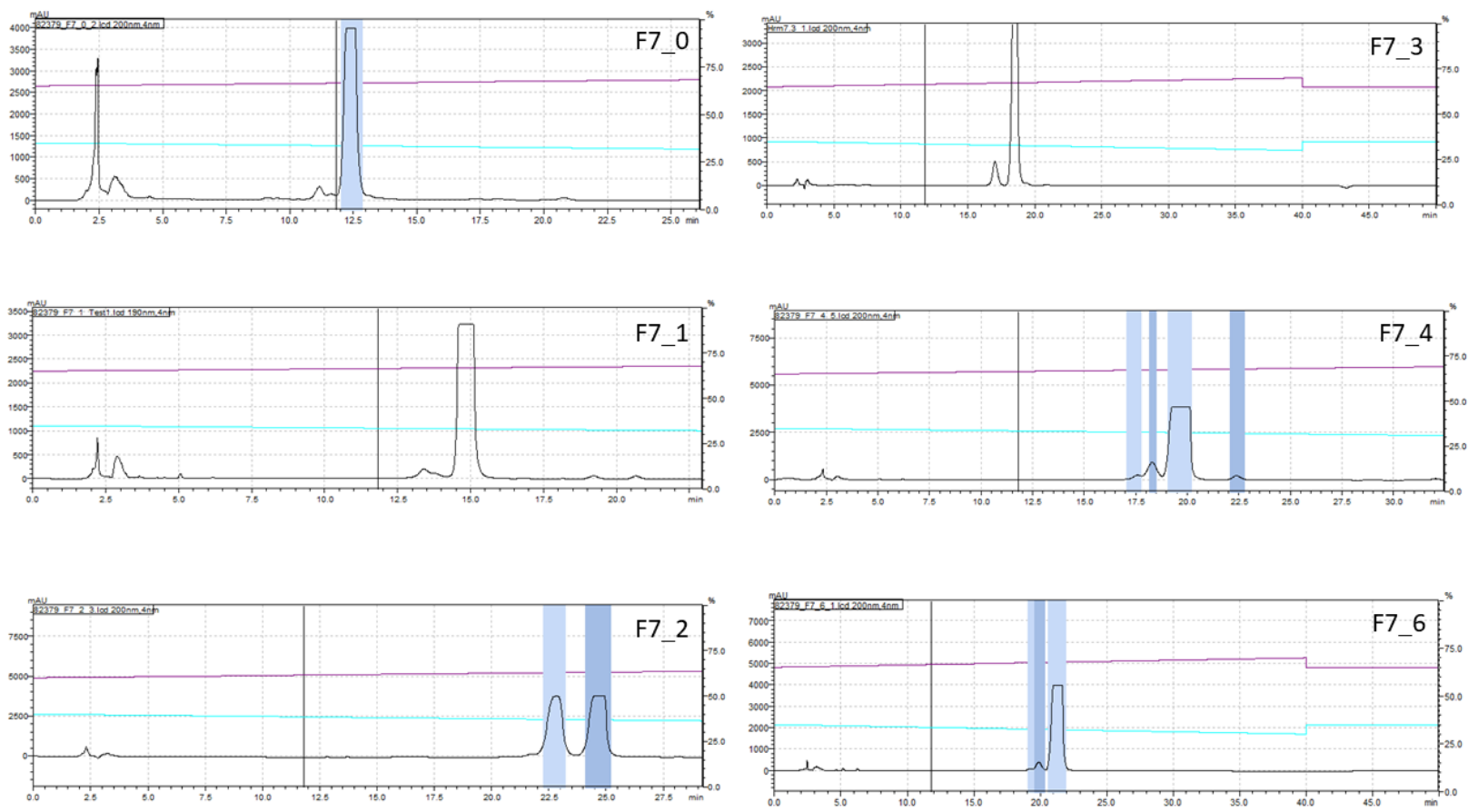

Figure S5. Final HPLC purification of F7_0 through F7_6 (compounds 1-6 respectively) monitoring at 200 $\mathrm{nm}$. All final purifications were accomplished using a Phenomenex phenyl-hexyl column $(250 \times 10 \mathrm{~mm})$; solvent $A: \mathrm{H}_{2} \mathrm{O}+0.1 \% \mathrm{FA}$; solvent $\mathrm{B}$ : $\mathrm{ACN} ; 4 \mathrm{mLmin}^{-1}$, linear increasing gradient from $65 \% \mathrm{~B}$ to $70 \% \mathrm{~B}$ over $40 \mathrm{~min}$. 


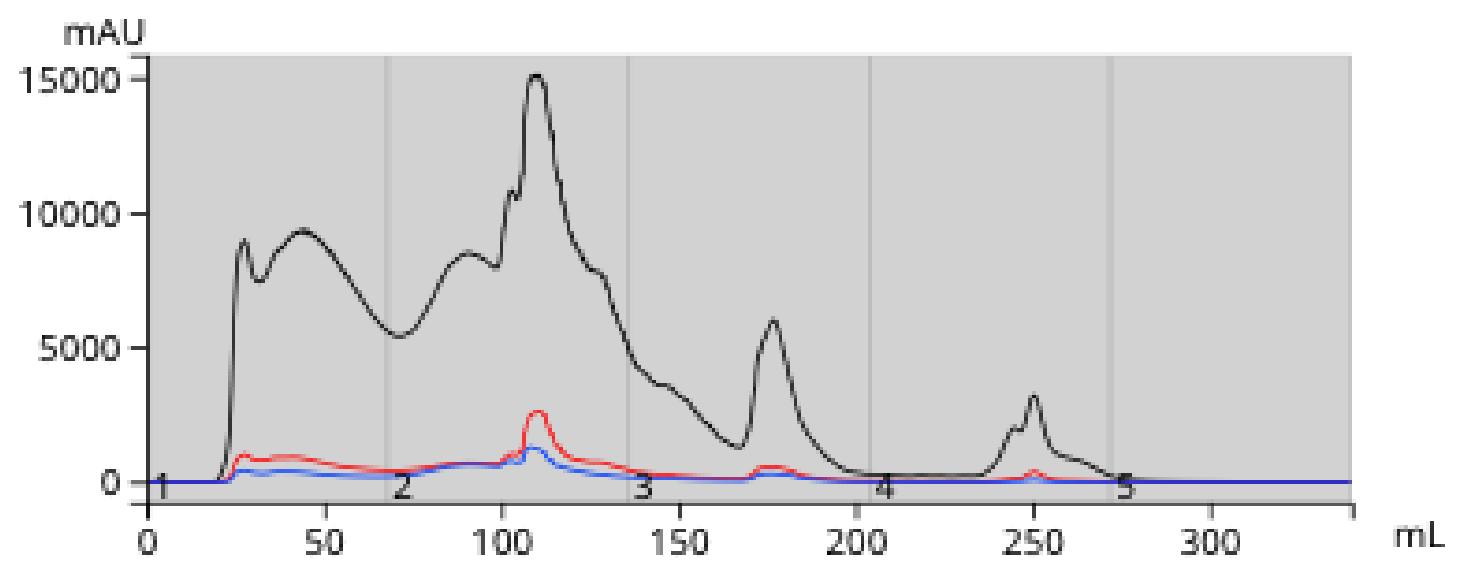

Figure S6. Initial Biotage fractionation of crude extract from sp. R312_4. Solvent A: $\mathrm{H}_{2} \mathrm{O}$; solvent B: $\mathrm{MeOH}$; solvent C: ACN; $C 18(12 \mathrm{~g})$, flow rate $20 \mathrm{mLmin}^{-1}$. Elution was monitored at $200 \mathrm{~nm}$ (red), $254 \mathrm{~nm}$ (blue), and $\lambda$-all (black, 198-400 nm).

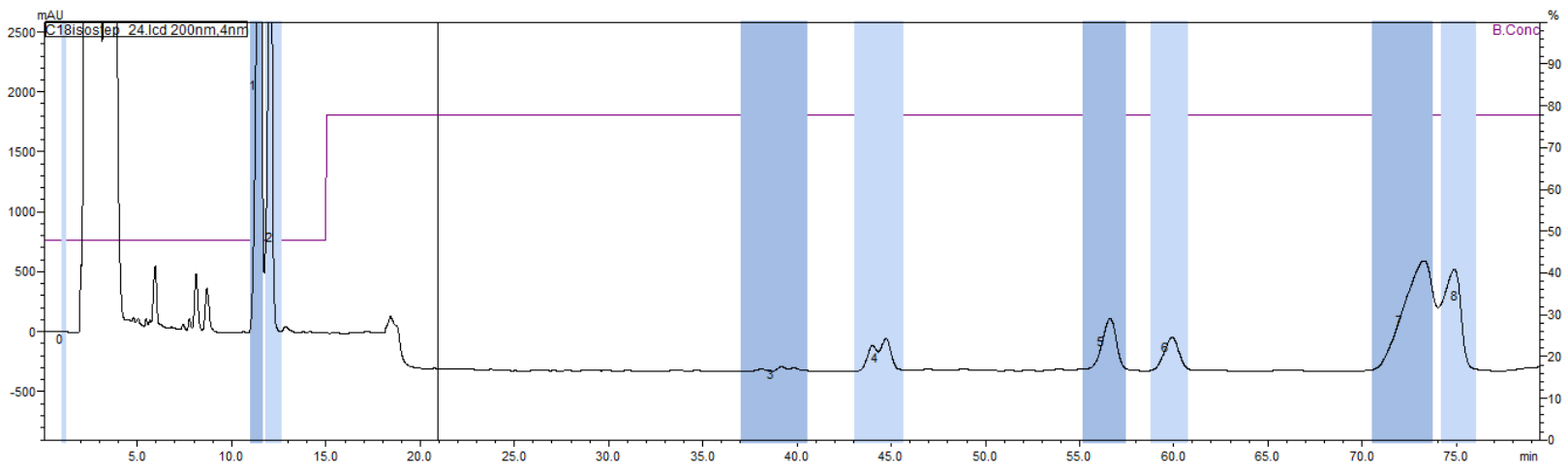

Figure S7. HPLC fractionation of F4/Cell extract from Biotage cleanup (see figure S5). Step 1: Solvent $A$ $\mathrm{H}_{2} \mathrm{O}+0.1 \%$ FA (53\%); solvent B: $\mathrm{ACN}(47 \%)$ 0-15 min; Step 2: Solvent $\mathrm{A} \mathrm{H}_{2} \mathrm{O}+0.1 \%$ FA (22\%); solvent B: ACN (78\%) 15-80 min Phenomenex Luna $5 \mu \mathrm{m}$ C18 $(250 \times 21.2 \mathrm{~mm})$ flow rate $4 \mathrm{mLmin}^{-1}$. 


\section{LC-MS Analysis}

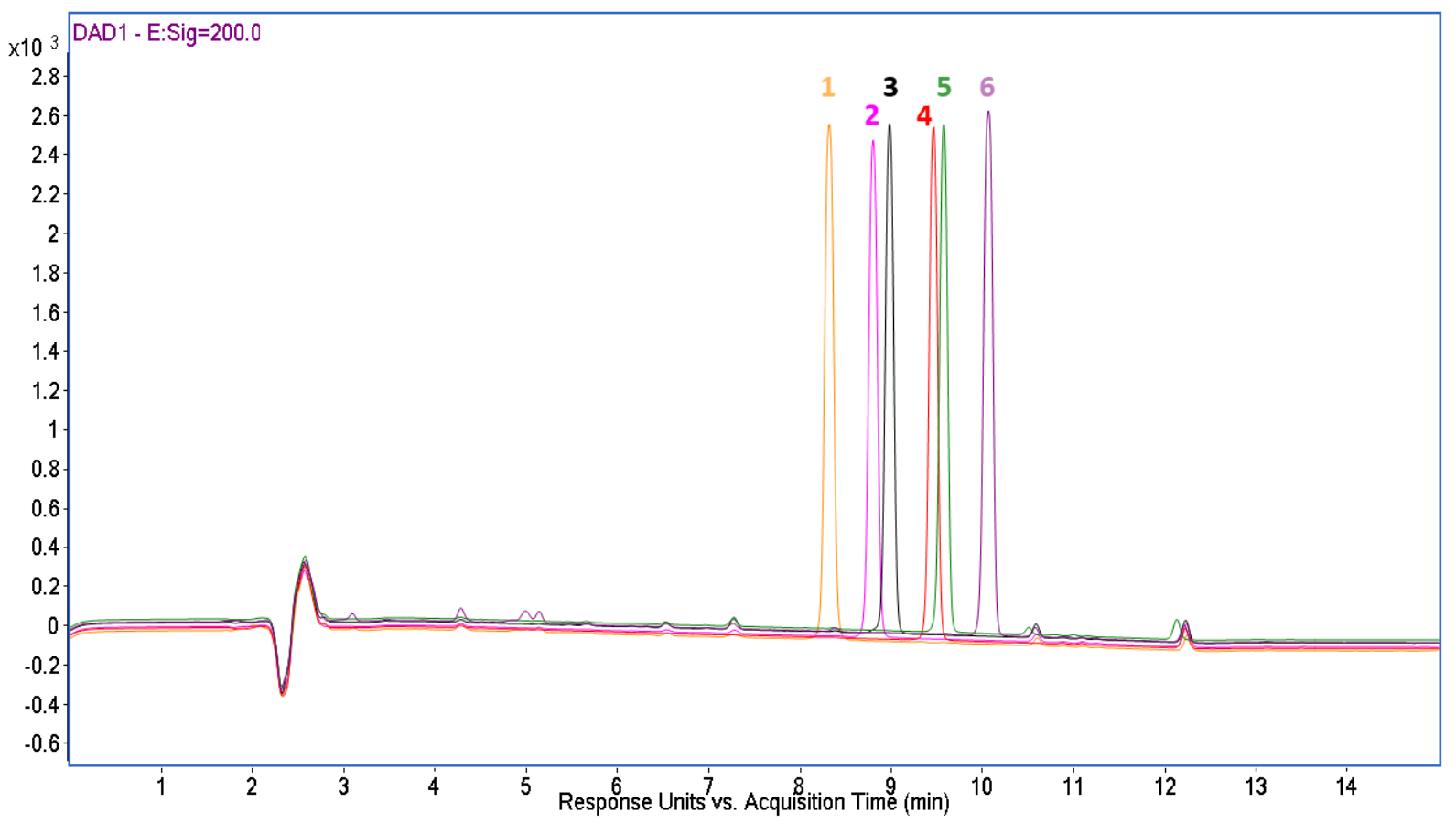

Figure S8. Overlaid LC-MS trace of surfactins 1-6, monitored at $200 \mathrm{~nm}$. Samples were analyzed using a

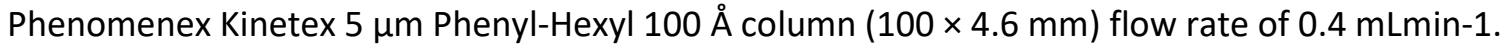

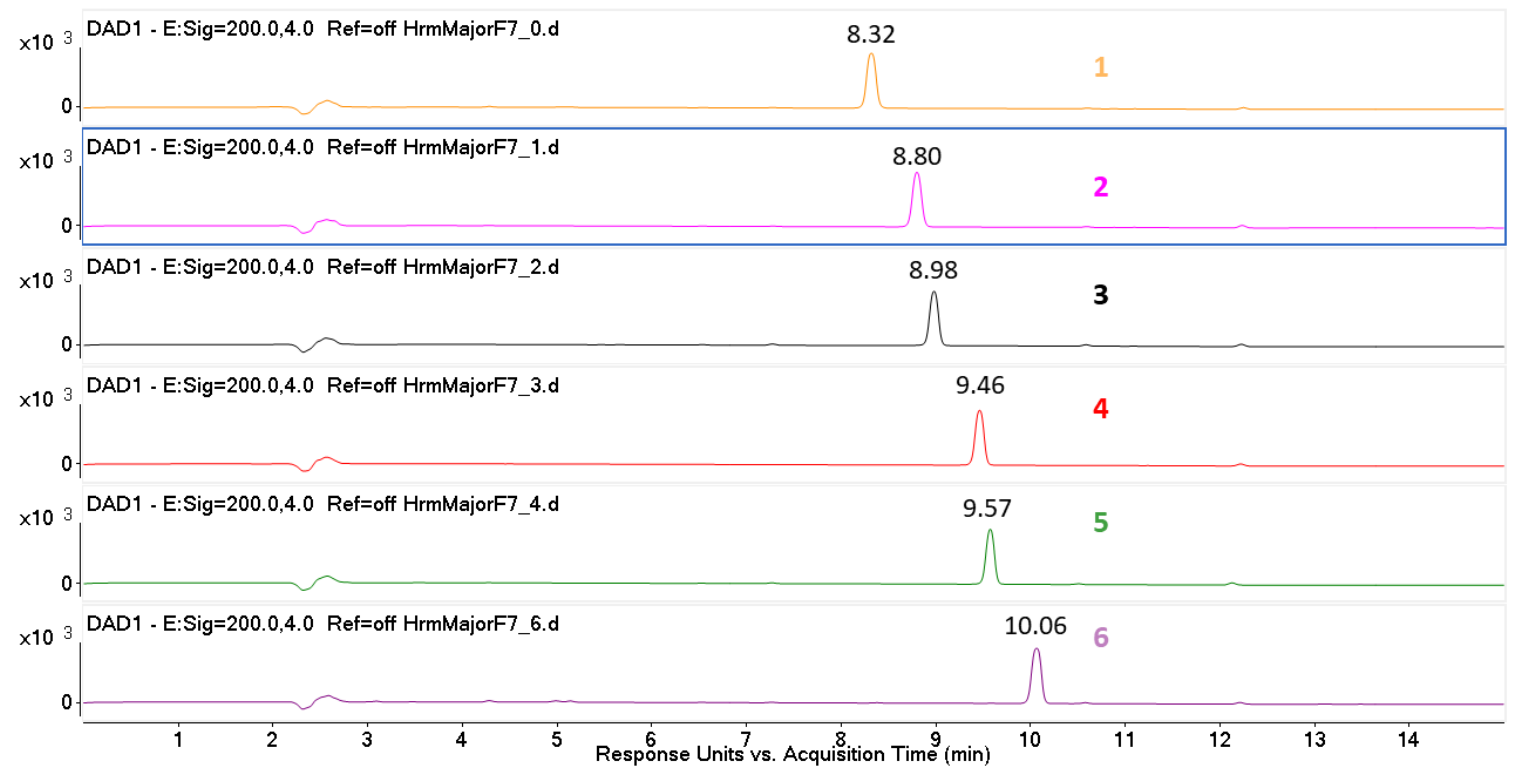

Figure S9. Single LC-MS traces of surfactins 1-6, monitored at $200 \mathrm{~nm}$, with retention times (min). 


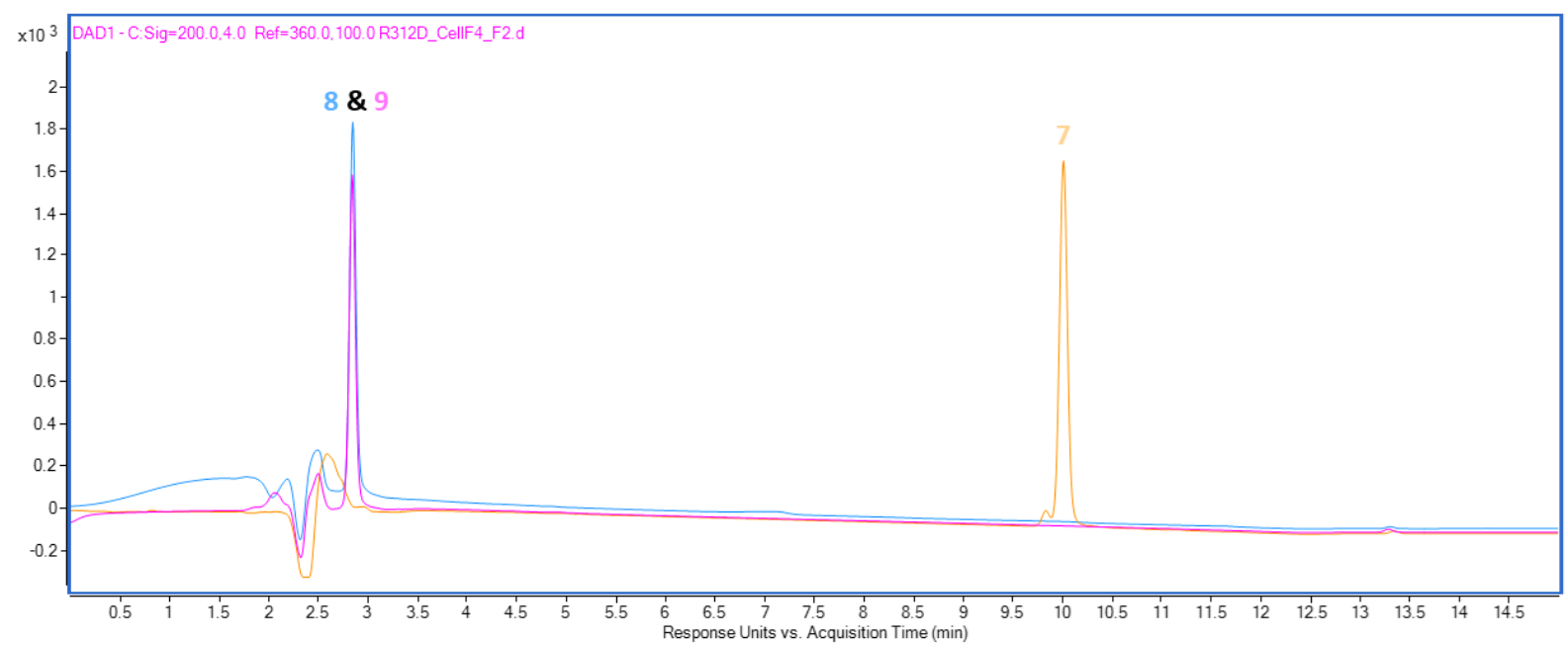

Figure S10. Overlaid LC-MS trace of surfactins and mycosubtilins 7-9, monitored at $200 \mathrm{~nm}$. Samples were analyzed using a Phenomenex Kinetex 5 mm Phenyl-Hexyl 100 Å column $(100 \times 4.6$ mm) flow rate of 0.4 $\mathrm{mLmin}^{-1}$.

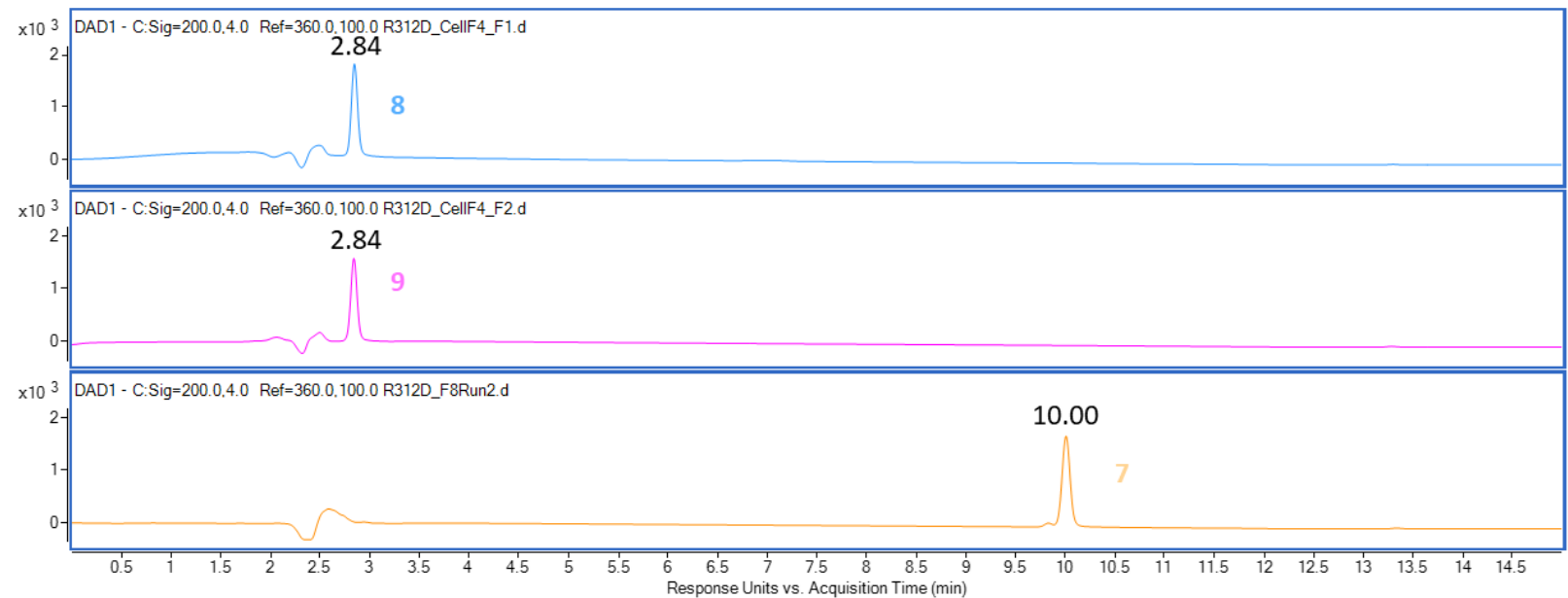

Figure S11. Single LC-MS traces of surfactins and mycosubtilins 7-9, monitored at $200 \mathrm{~nm}$, with retention times (min). 


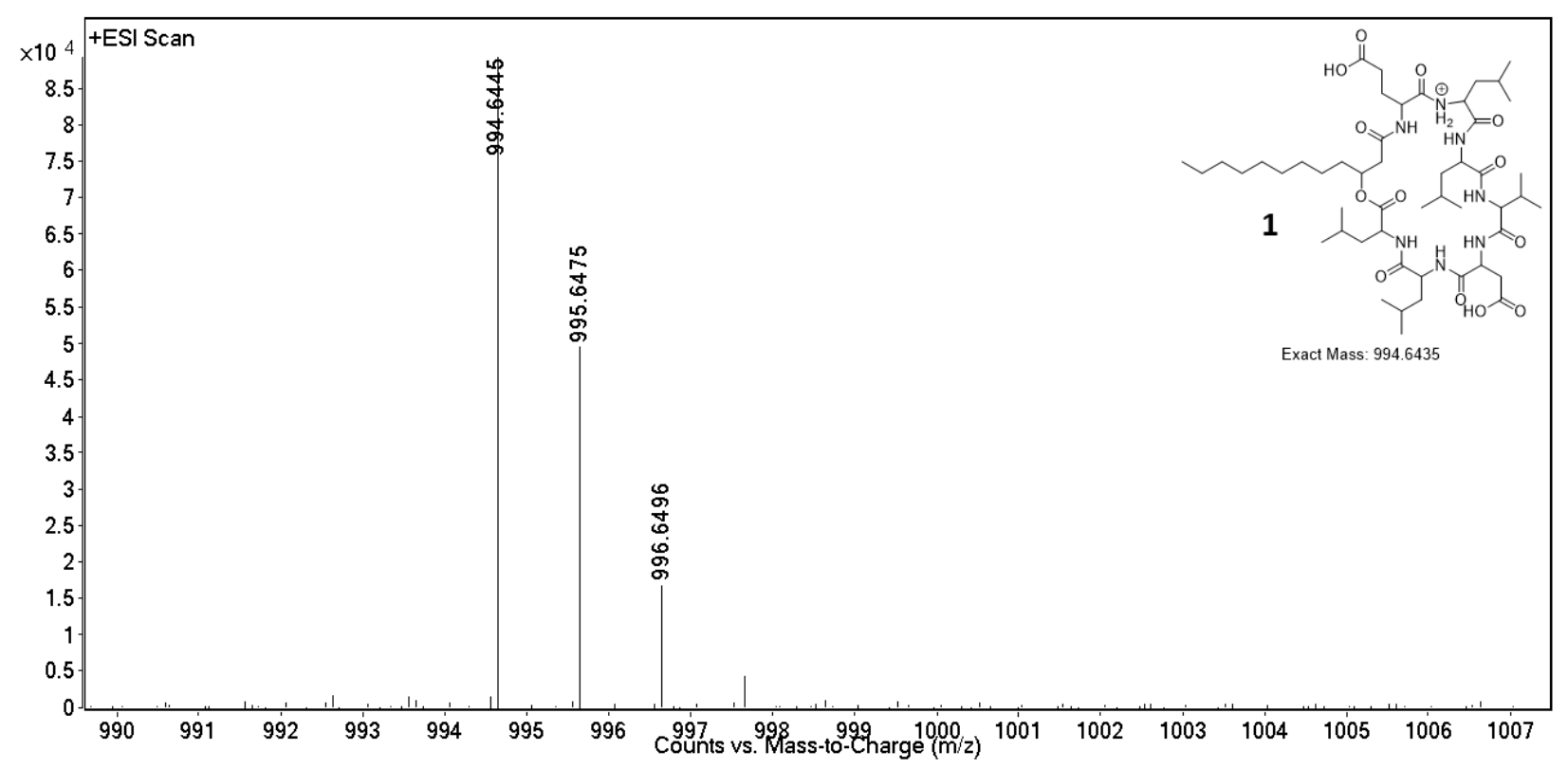

Figure S12. Mass spectrum of compound 1.

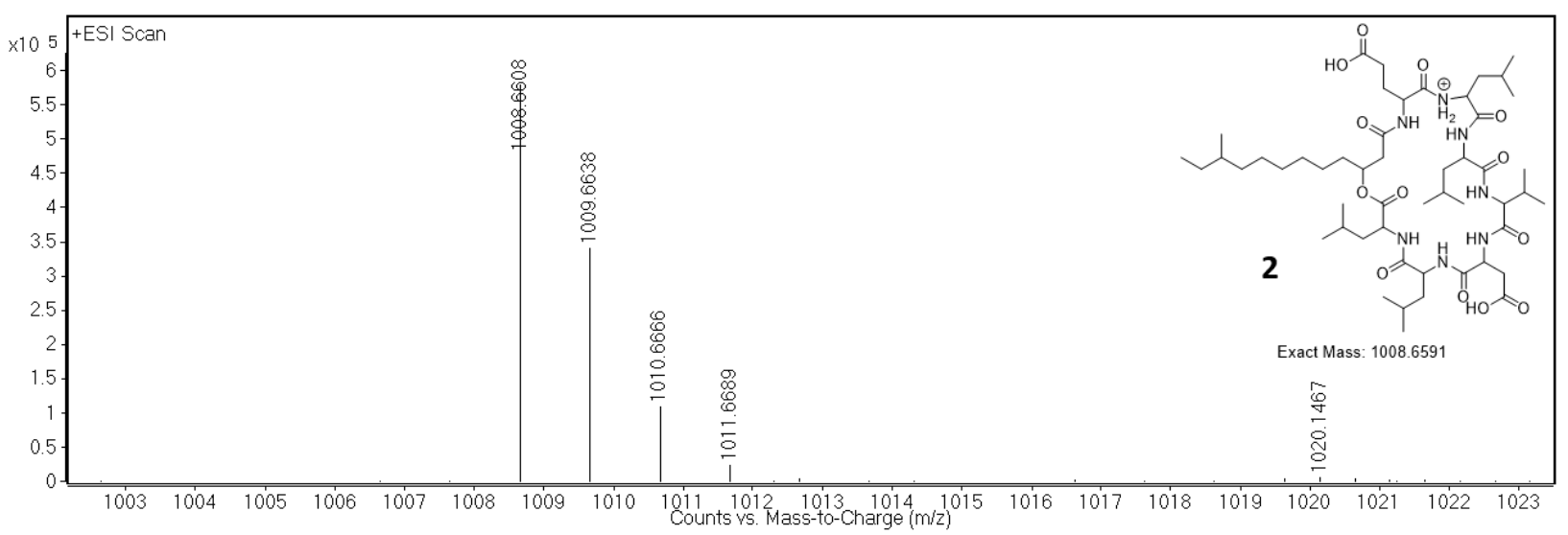

Figure S13. Mass spectrum of compound 2. 


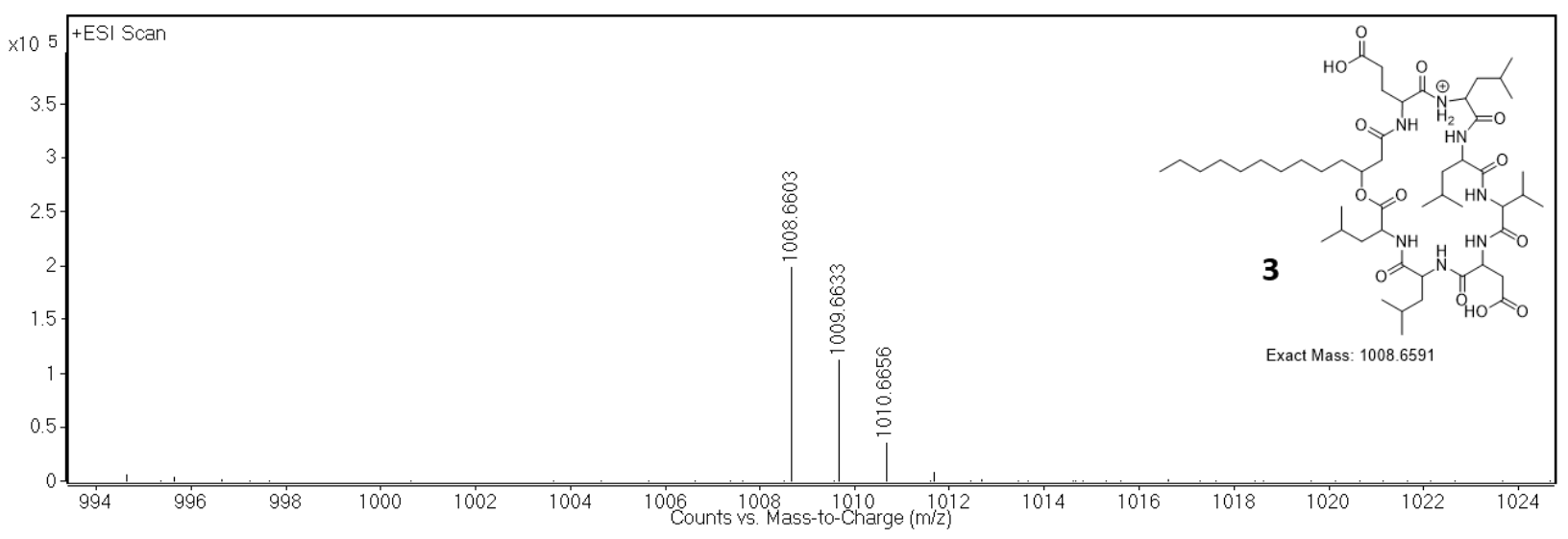

Figure S14. Mass spectrum of compound 3.

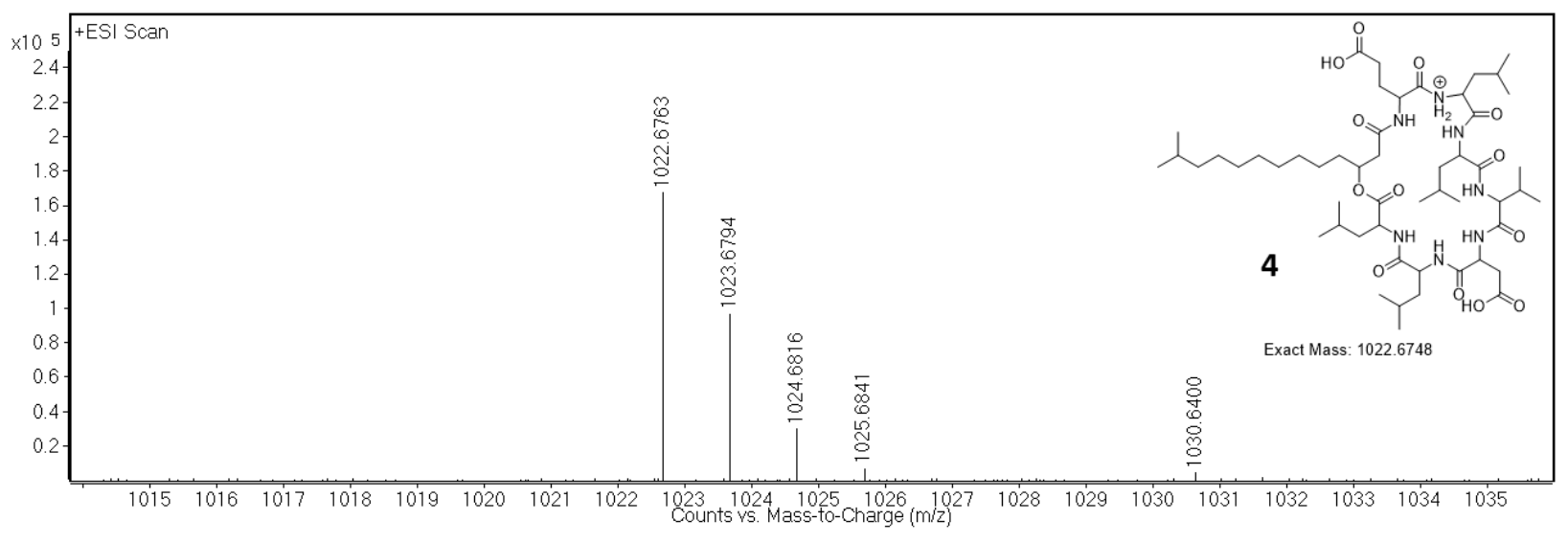

Figure S15. Mass spectrum of compound 4. 


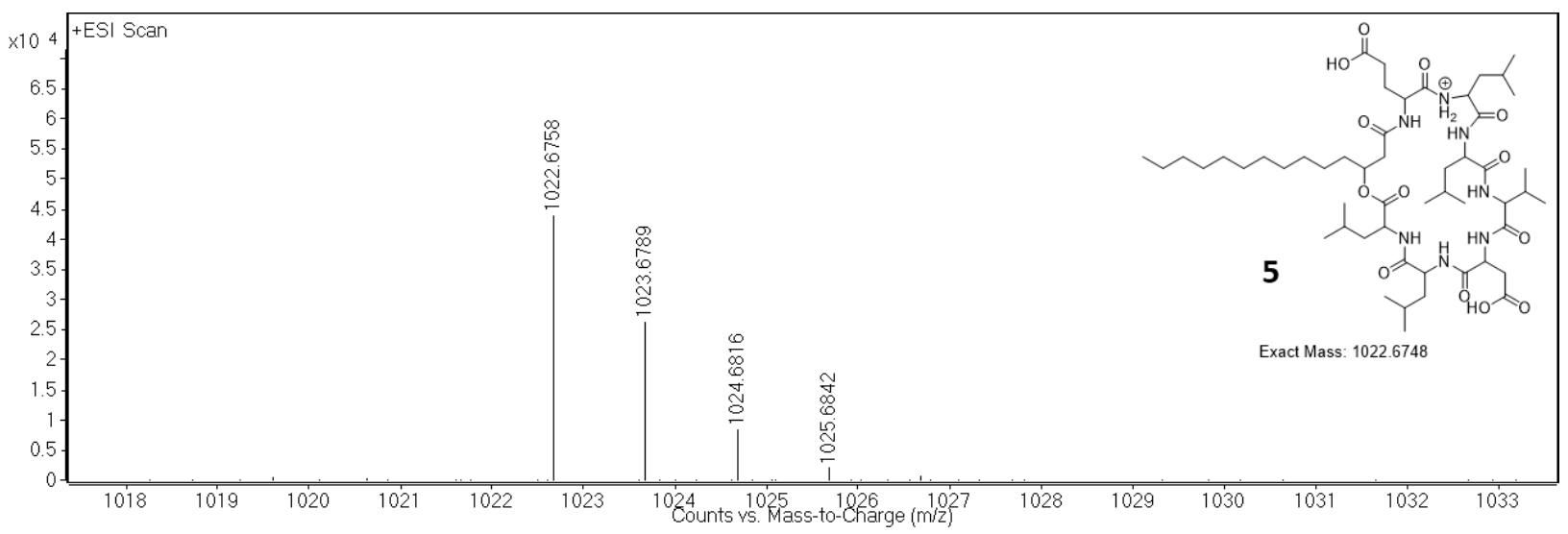

Figure S16. Mass spectrum of compound 5.

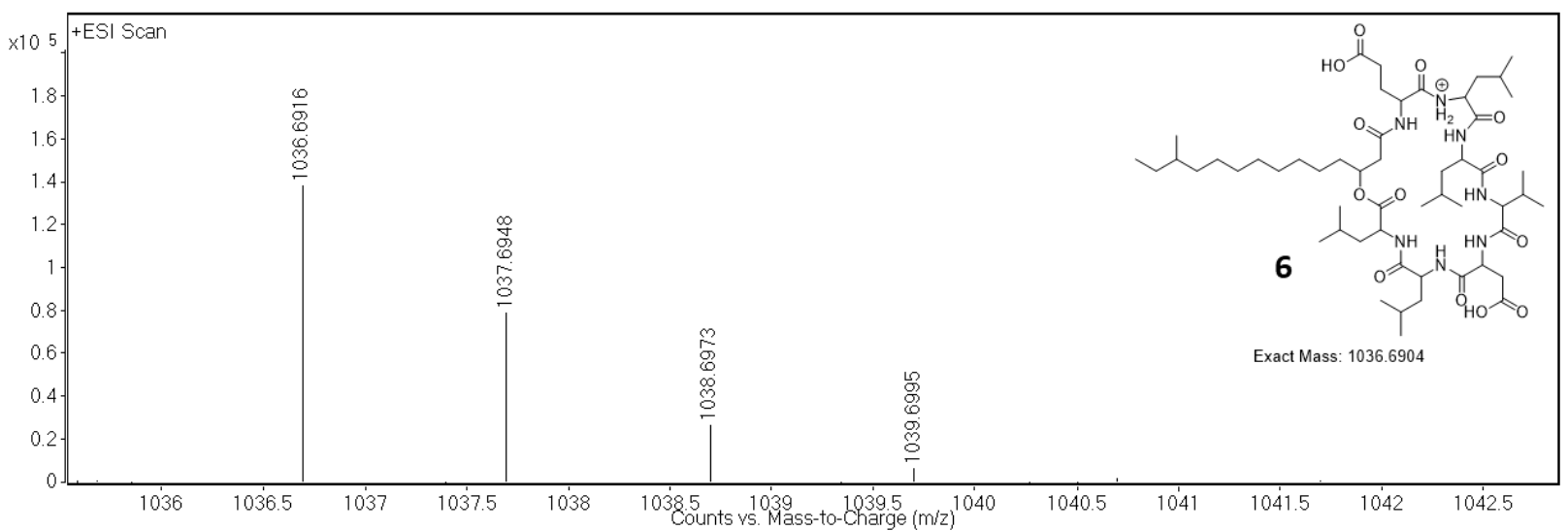

Figure S17. Mass spectrum of compound 6. 


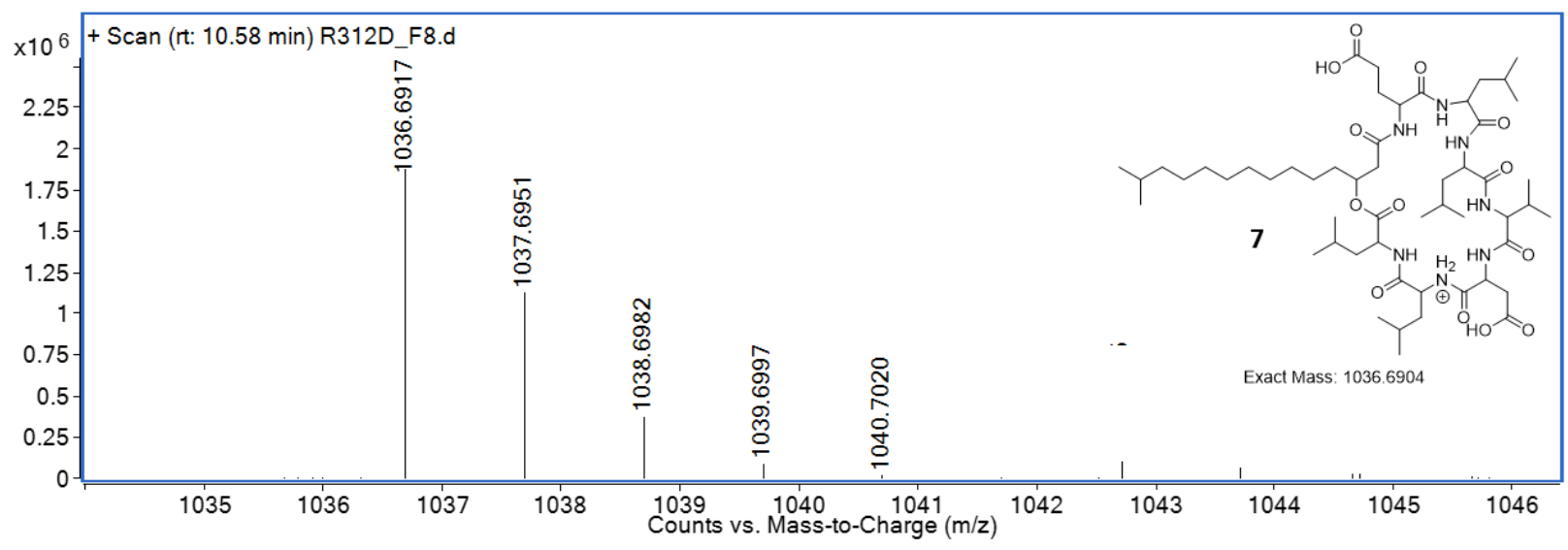

Figure S18. Mass spectrum of compound 7.

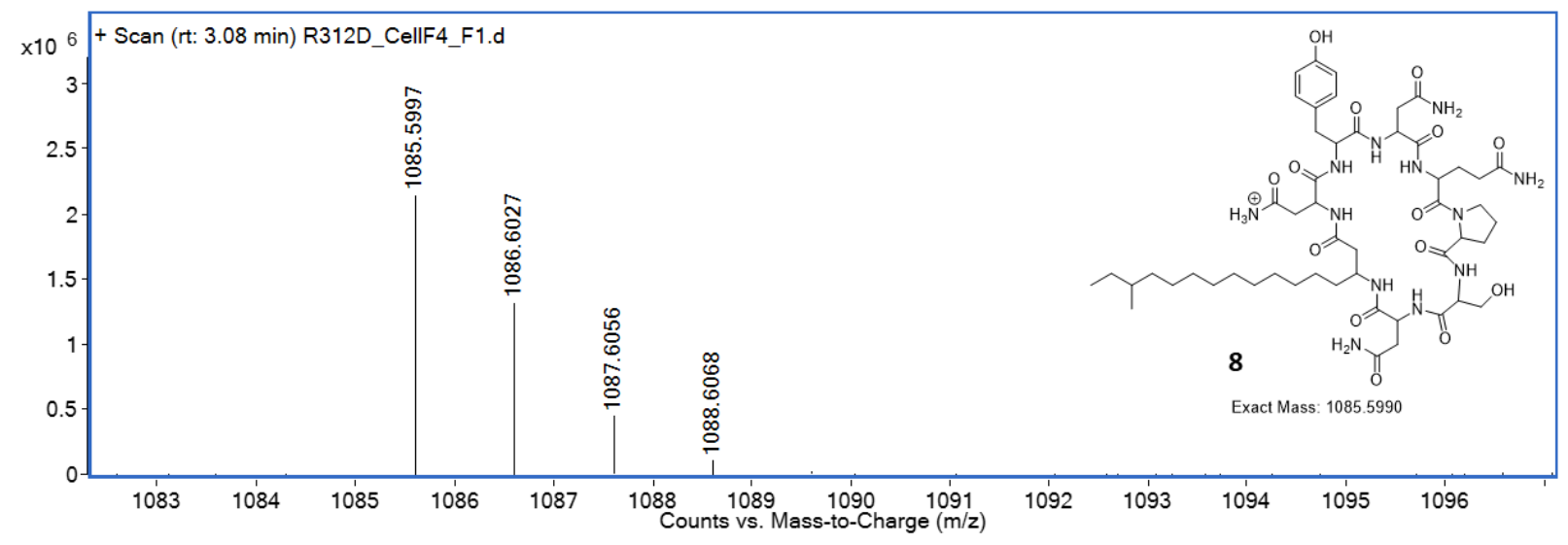

Figure S19. Mass spectrum of compound 8.

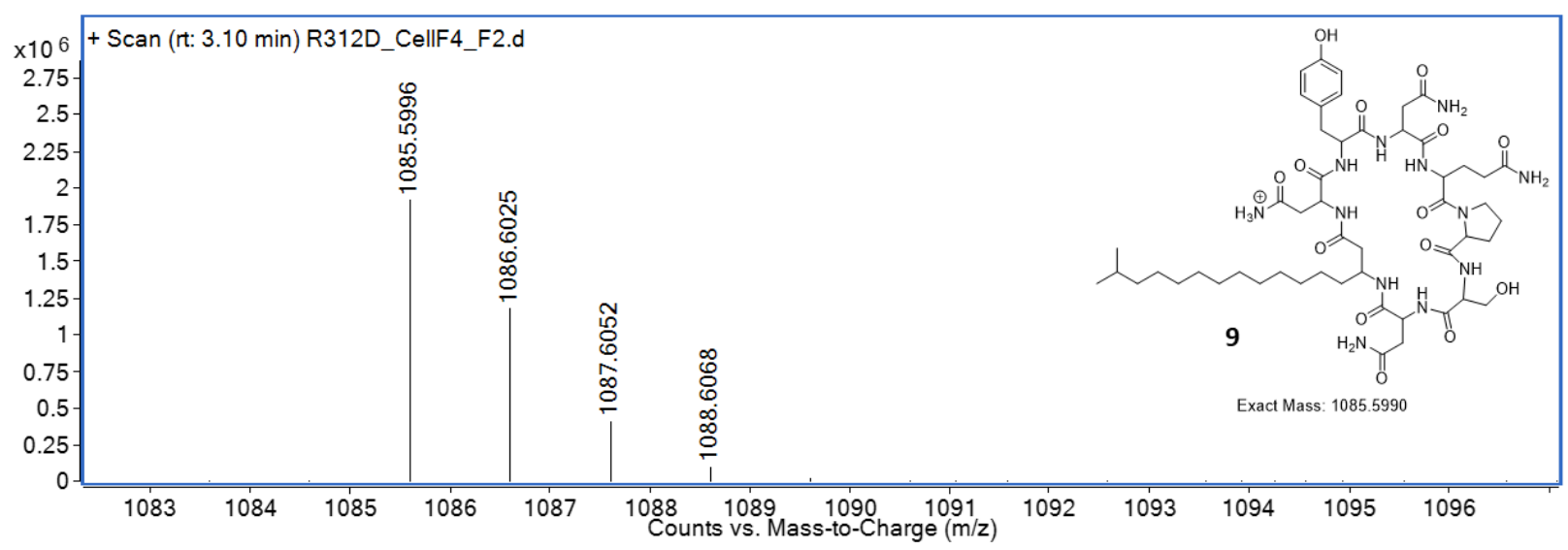

Figure S20. Mass spectrum of compound $\mathbf{9}$. 


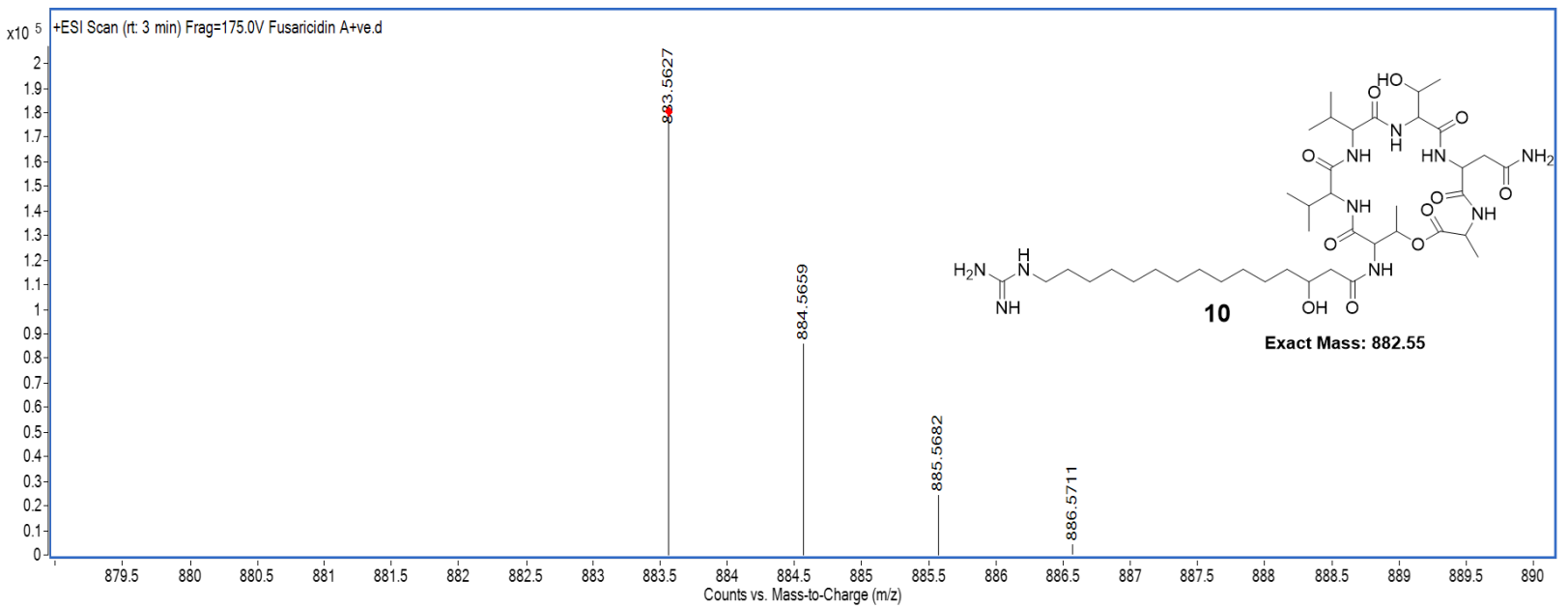

Figure S21. Mass spectrum of compound $\mathbf{1 0 .}$

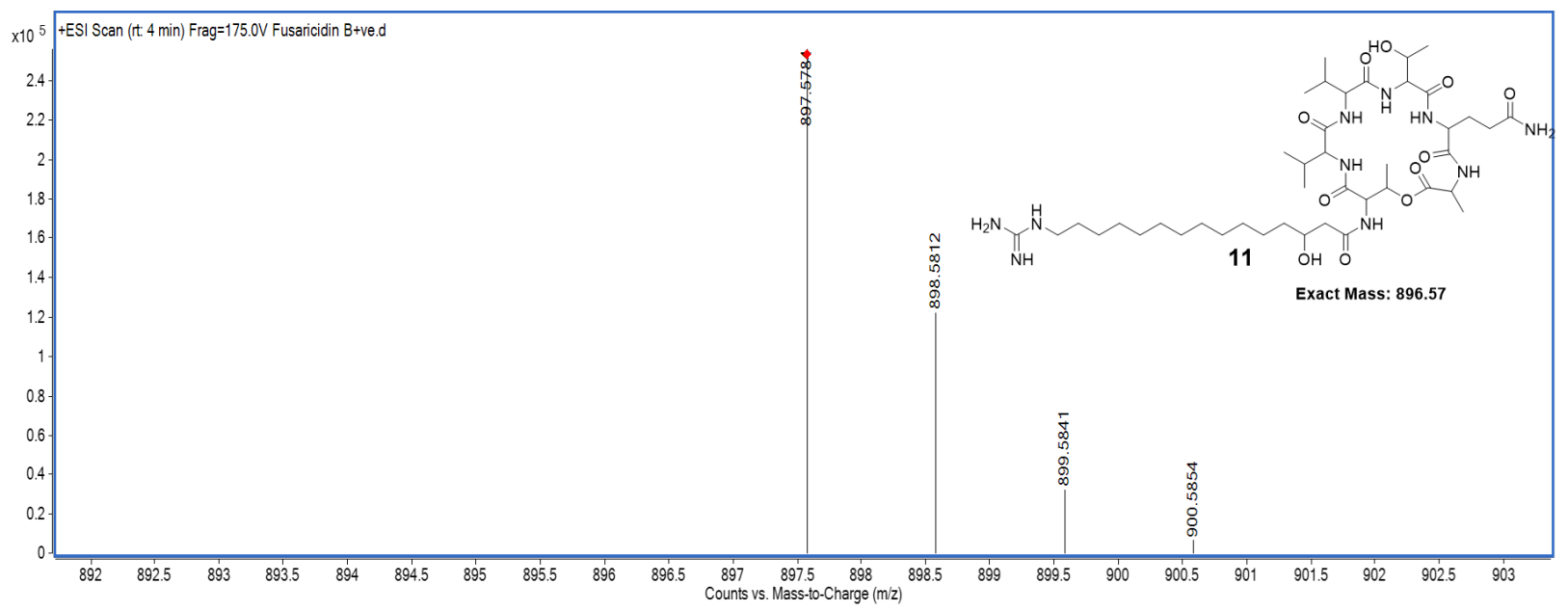

Figure S22. Mass spectrum of compound 11. 


\section{MSMS Analysis}

1a

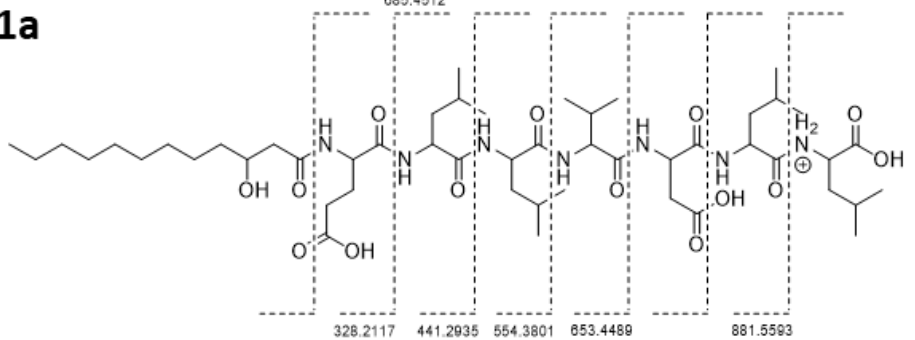

$2 a$

(1)

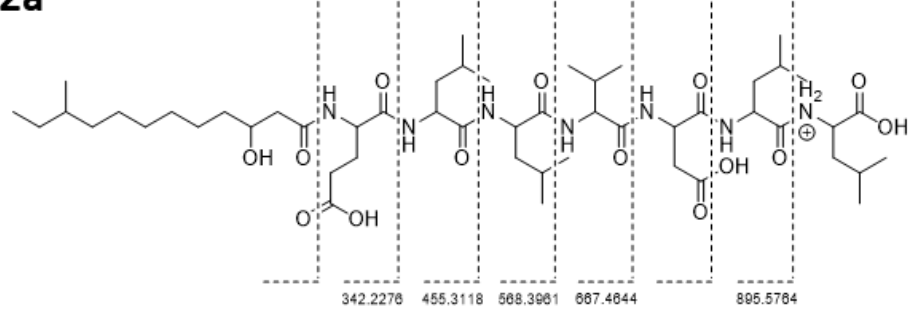

$3 a$

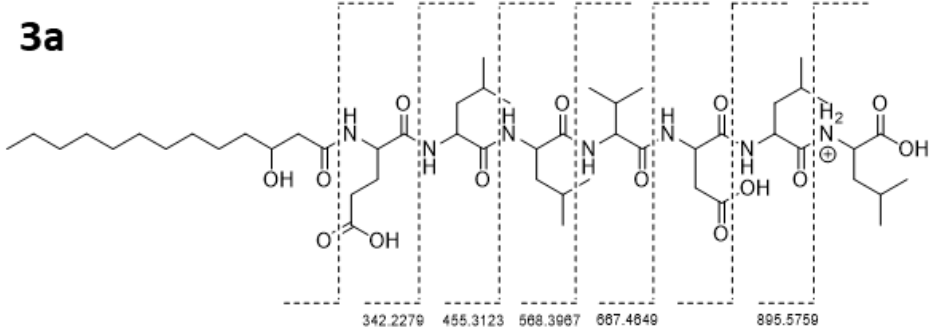

4a

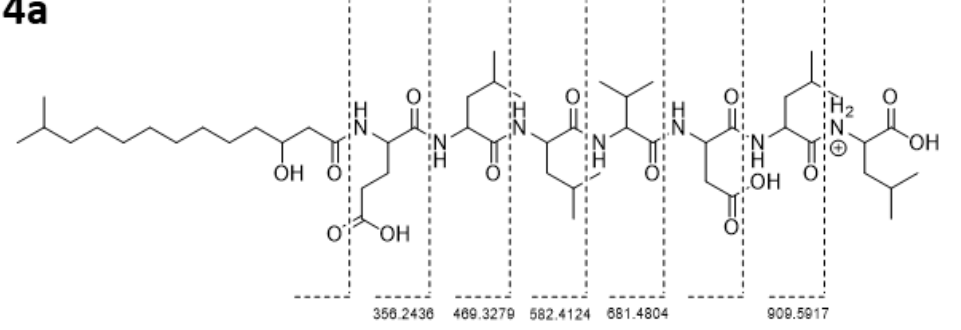

$5 a$

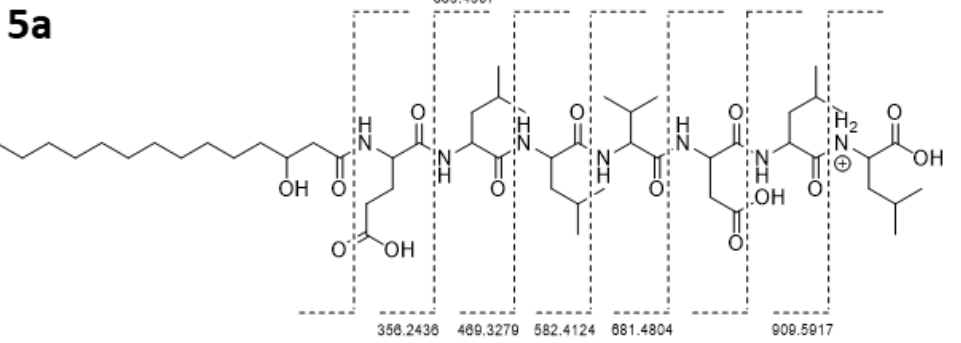

$6 a$

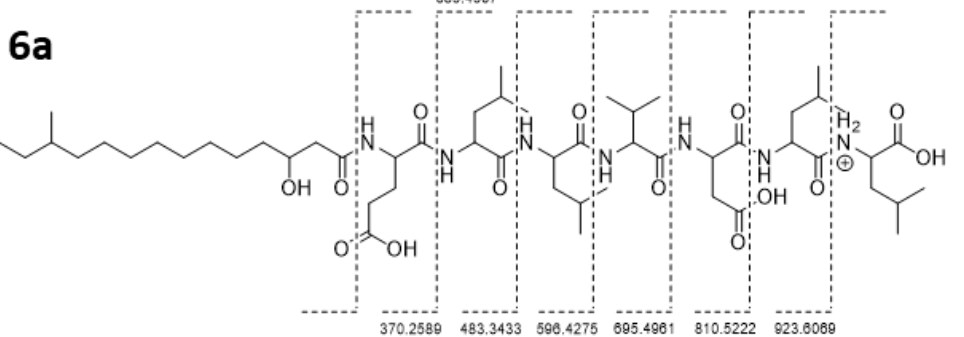

Figure S23. Characteristic fragments of linearized 1a-6a in tandem MS experiments. Dashed lines through amide linkages illustrate " $\mathrm{y}$ " and " $\mathrm{b}$ " fragments obtained. 

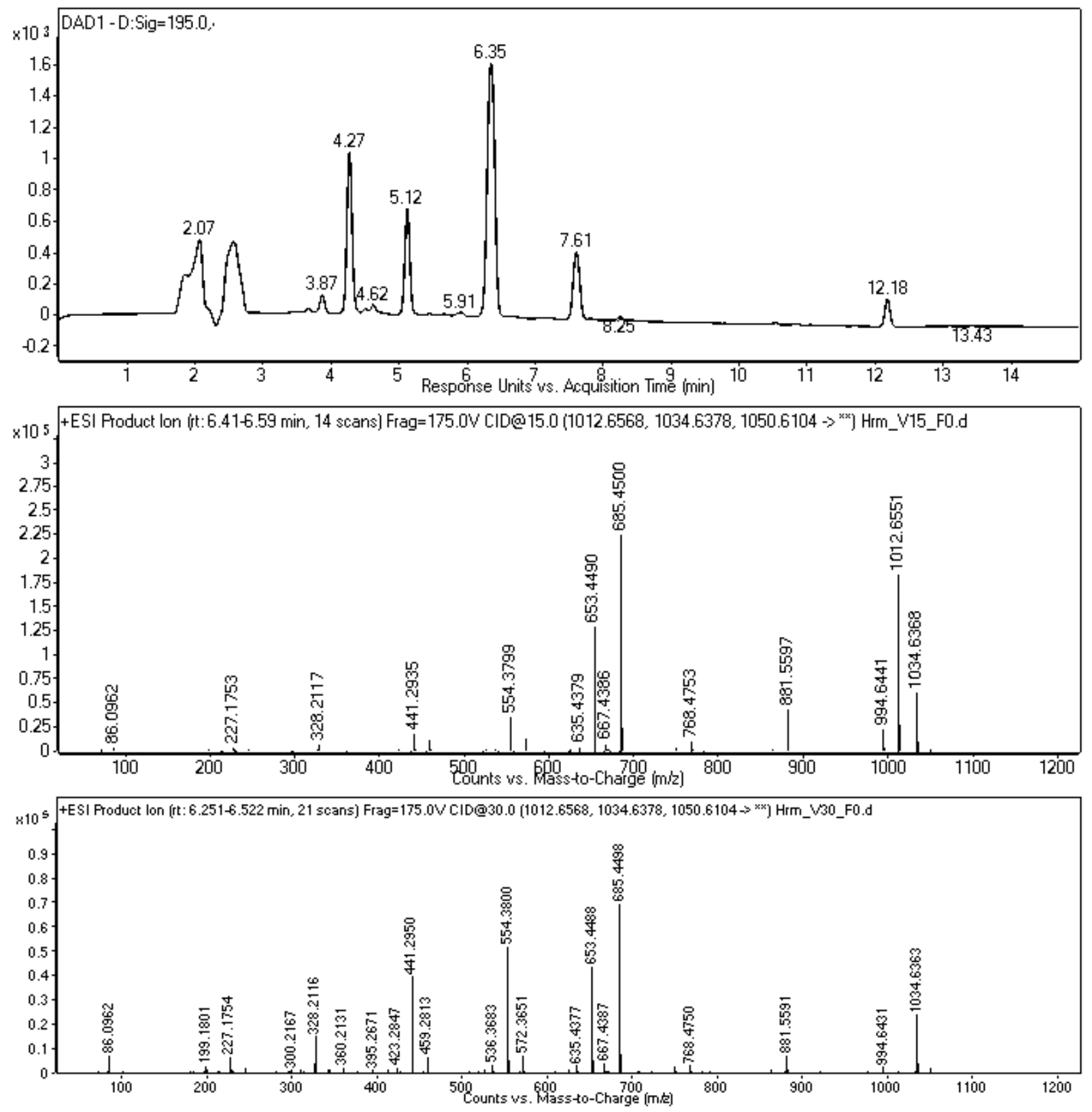

Figure S24. LC-MSMS trace of compound 1a, illustrating (Top) LC-trace of hydrolyzed material (1a at 6.35 min); (middle) MSMS spectrum illustrating MS2 of 1012@cid15; (bottom) MSMS spectrum illustrating MS2 of 1012@cid30. 

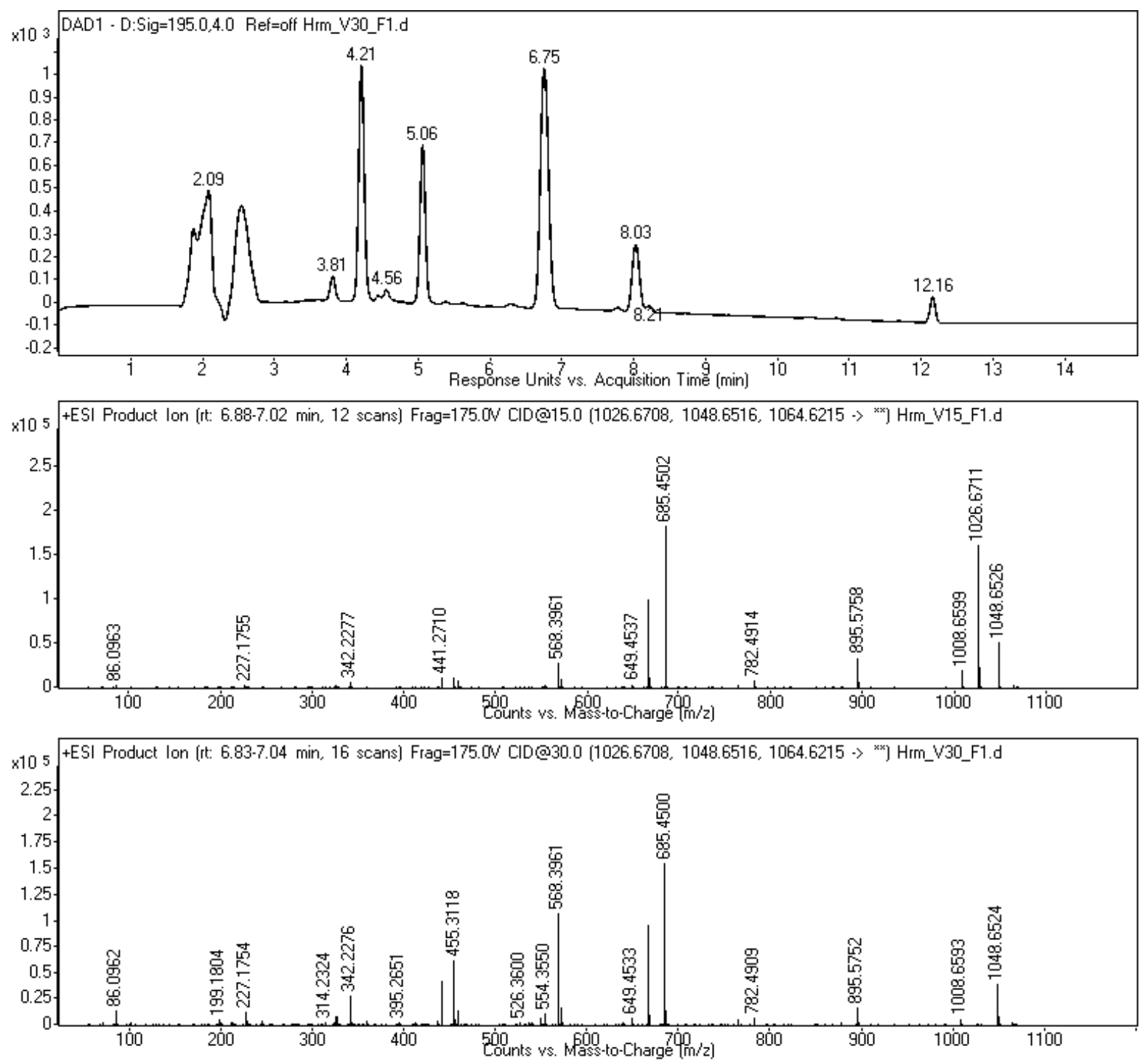

Figure S25. LC-MSMS trace of compound 2a, illustrating (Top) LC-trace of hydrolyzed material (2a at 6.75 min); (middle) MSMS spectrum illustrating MS2 of 1026@cid15; (bottom) MSMS spectrum illustrating MS2 of 1026@cid30. 

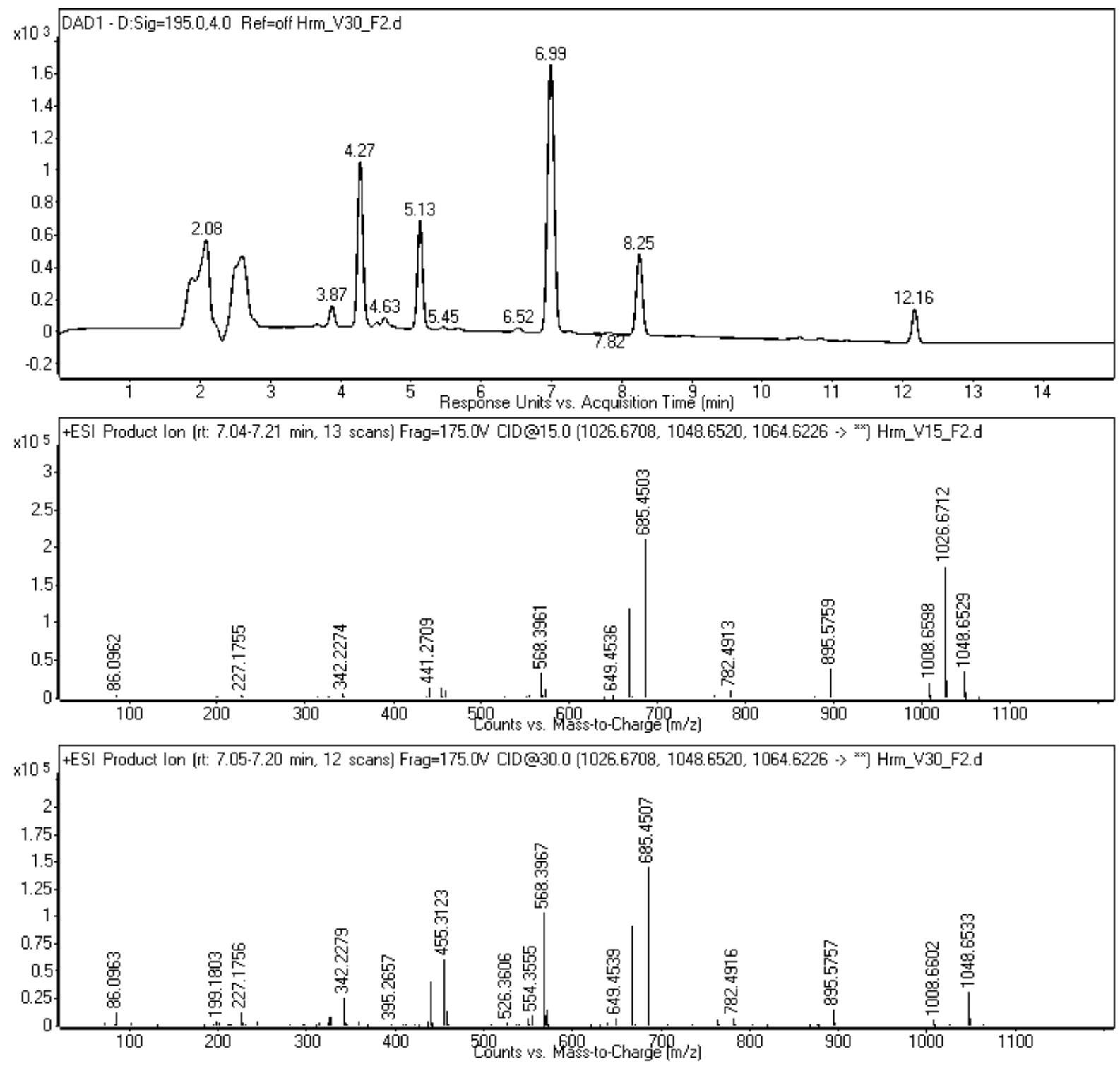

Figure S26. LC-MSMS trace of compound 3a, illustrating (Top) LC-trace of hydrolyzed material (3a at 6.99 min); (middle) MSMS spectrum illustrating MS2 of 1026@cid15; (bottom) MSMS spectrum illustrating MS2 of 1026@cid30. 

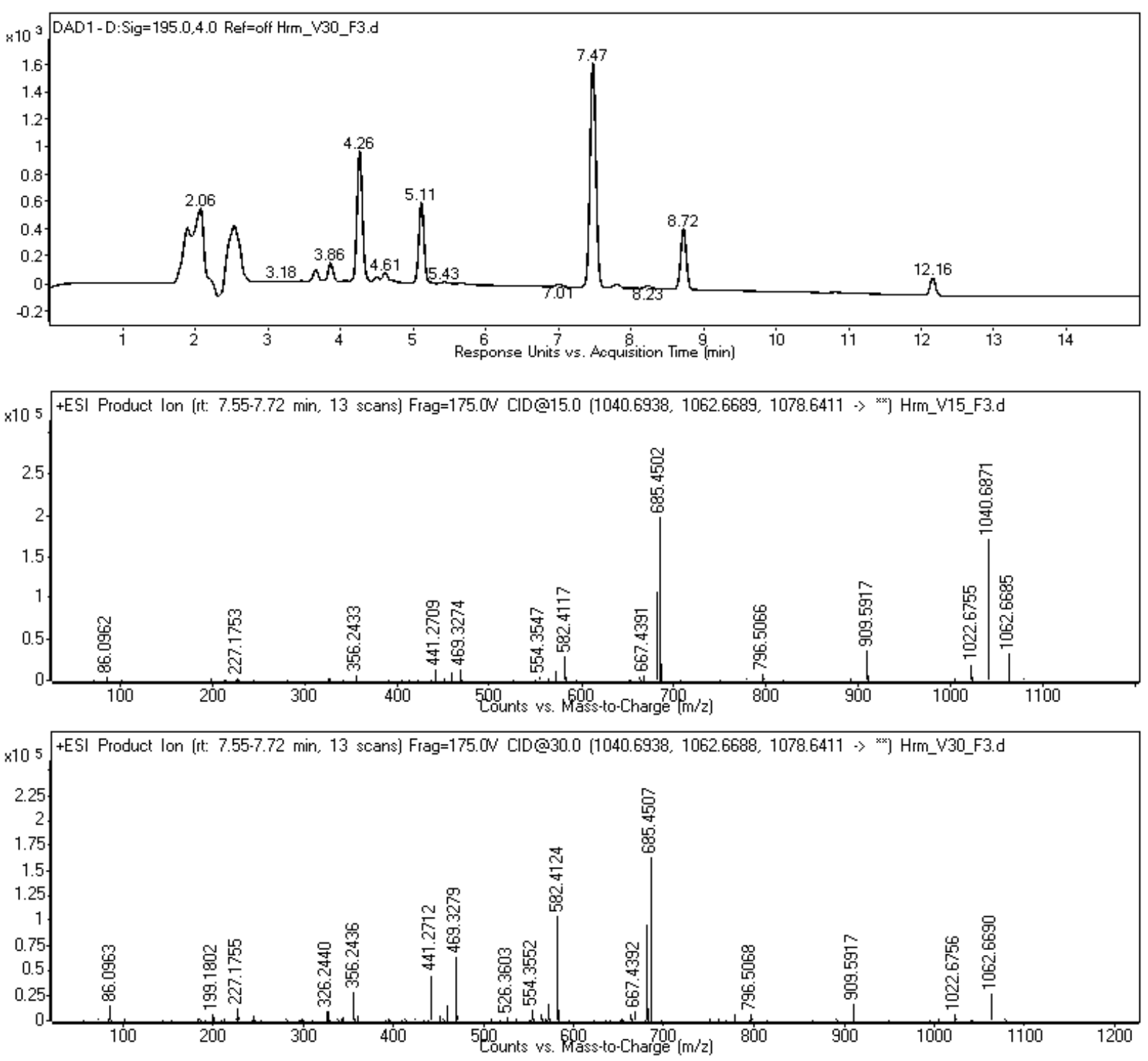

Figure S27. LC-MSMS trace of compound 4a, illustrating (Top) LC-trace of hydrolyzed material (4a at 7.47 min); (middle) MSMS spectrum illustrating MS2 of 1040@cid15; (bottom) MSMS spectrum illustrating MS2 of 1040@cid30. 

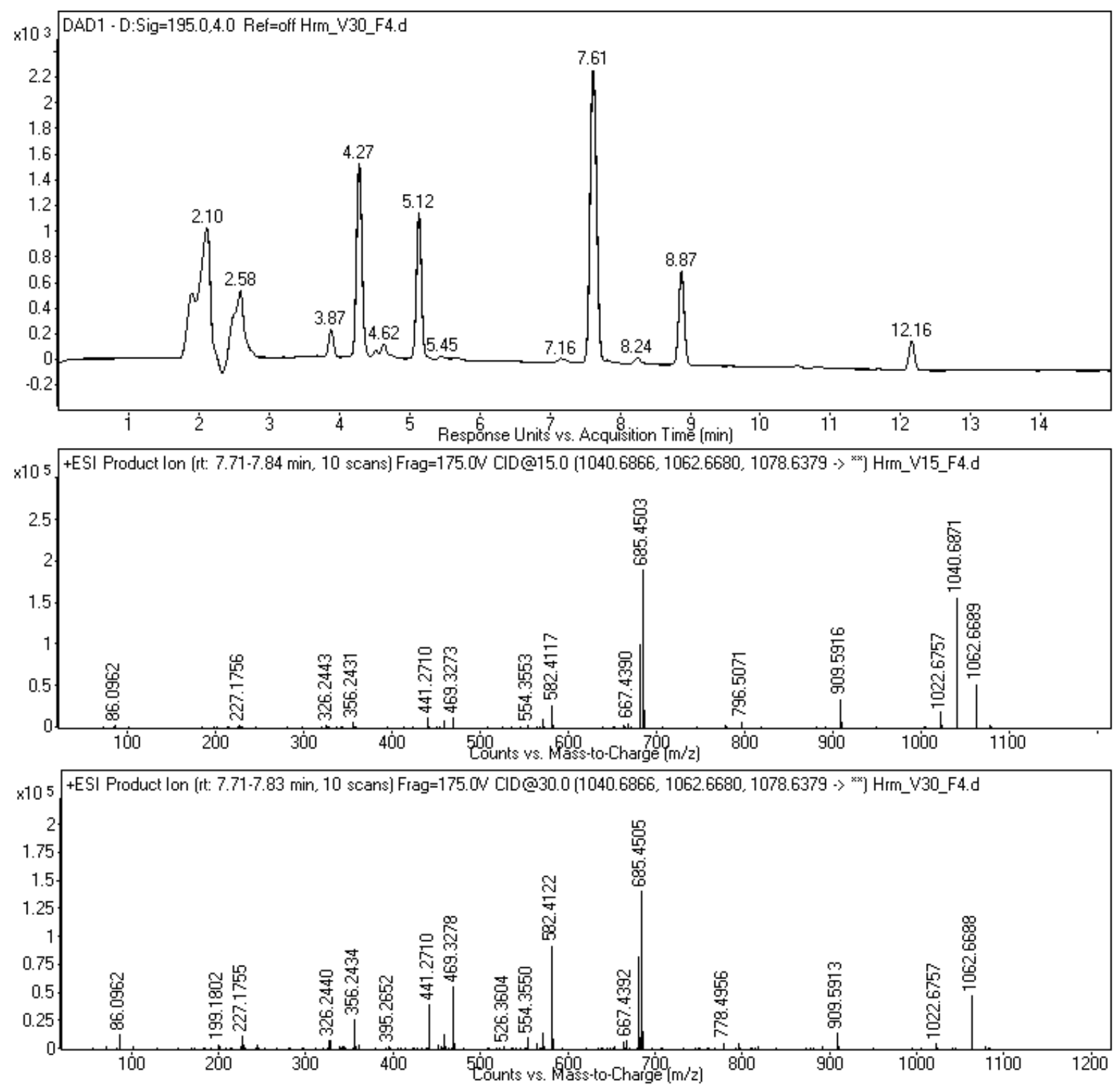

Figure S28. LC-MSMS trace of compound 5a, illustrating (Top) LC-trace of hydrolyzed material (5a at 7.61 min); (middle) MSMS spectrum illustrating MS2 of $1040 @$ cid15; (bottom) MSMS spectrum illustrating MS2 of 1040@cid30. 

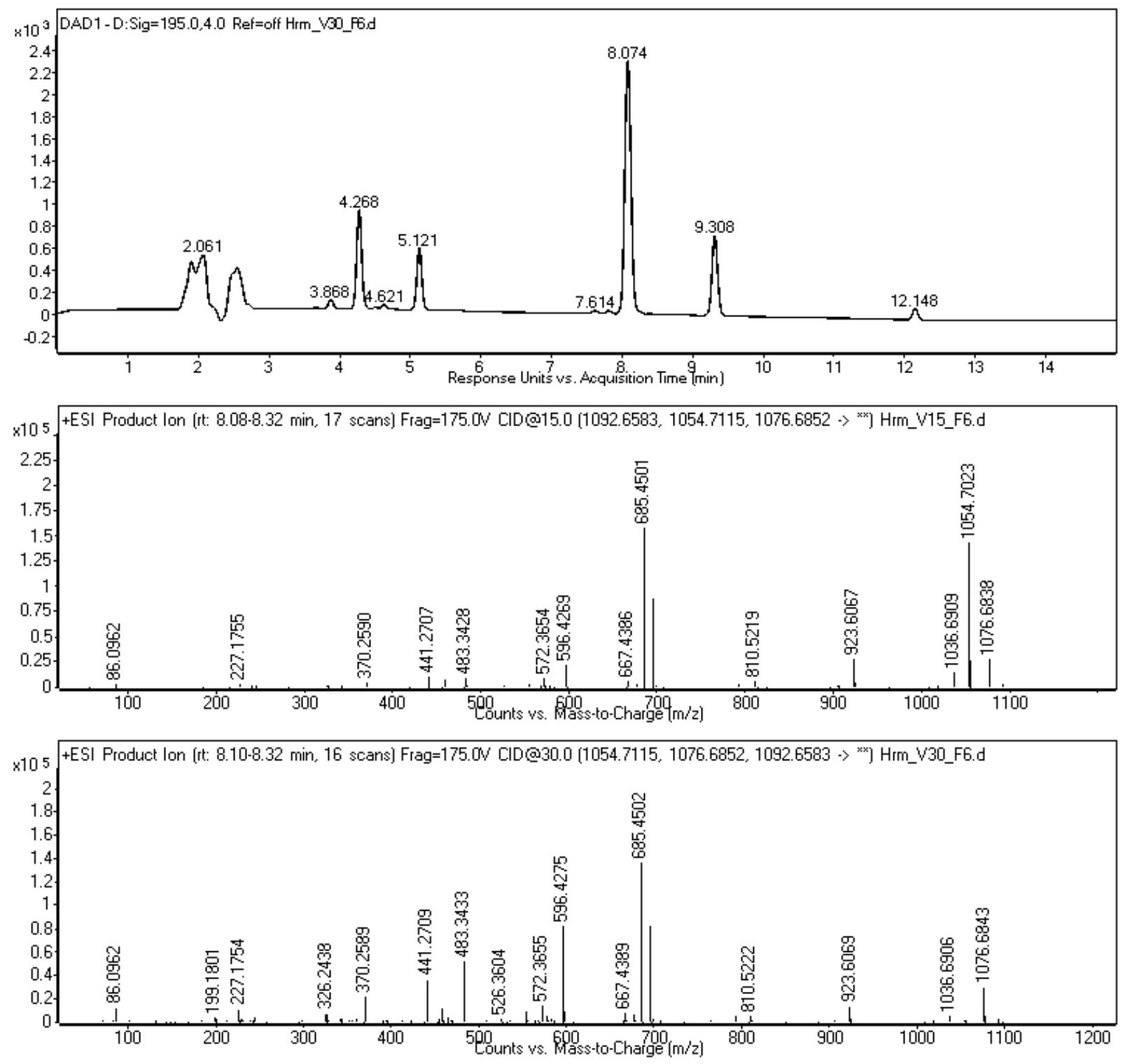

Figure S29. LC-MSMS trace of compound 6a, illustrating (Top) LC-trace of hydrolyzed material (6a at 8.07 min); (middle) MSMS spectrum illustrating MS2 of 1054@cid15; (bottom) MSMS spectrum illustrating MS2 of 1054@cid30. 


\section{Compound Data}

[Leu ${ }^{7}$ ] surfactin $n-\mathrm{C}_{12}$ (1): off-white solid; ${ }^{1} \mathrm{H}$ and ${ }^{13} \mathrm{C}$ NMR data, Table S1; HRESIMS $\mathrm{m} / z$ found 994.6435 [M + H] ${ }^{+}$(calcd for $\left.\mathrm{C}_{50} \mathrm{H}_{88} \mathrm{~N}_{7} \mathrm{O}_{13}, 994.6435\right) ; \Delta p p m=1.00$.

Linear [Leu $]$ ] surfactin $n-\mathrm{C}_{12}(1 \mathrm{a})$ : HRESIMS $\mathrm{m} / \mathrm{z}$ found $1012.6551[\mathrm{M}+\mathrm{H}]^{+}\left(\right.$calcd for $\left.\mathrm{C}_{50} \mathrm{H}_{90} \mathrm{~N}_{7} \mathrm{O}_{14}, 1012.6540\right) ; \Delta \mathrm{ppm}=$ 1.08 .

[Leu ${ }^{7}$ ] surfactin anteiso- $\mathrm{C}_{13}(\mathbf{2})$ : off-white solid; ${ }^{1} \mathrm{H}$ and ${ }^{13} \mathrm{C}$ NMR data, Table S2; HRESIMS $\mathrm{m} / \mathrm{z}$ found 1008.6608 [M + H] ${ }^{+}$ (calcd for $\mathrm{C}_{51} \mathrm{H}_{90} \mathrm{~N}_{7} \mathrm{O}_{13}, 1008.6591$ ); $\Delta \mathrm{ppm}=1.68$.

Linear [Leu'] surfactin anteiso- $\mathrm{C}_{13}(2 \mathrm{a})$ : HRESIMS $\mathrm{m} / \mathrm{z}$ found $1026.6708[\mathrm{M}+\mathrm{H}]^{+}$(calcd for $\mathrm{C}_{51} \mathrm{H}_{92} \mathrm{~N}_{7} \mathrm{O}_{14}, 1026.6697$ ); $\Delta \mathrm{ppm}=1.07$.

[Leu ${ }^{7}$ ] surfactin $n-\mathrm{C}_{13}$ (3): off-white solid; ${ }^{1} \mathrm{H}$ and ${ }^{13} \mathrm{C}$ NMR data, Table S3; HRESIMS $\mathrm{m} / z$ found 1008.6603 [M $\left.+\mathrm{H}\right]^{+}$(calcd for $\mathrm{C}_{51} \mathrm{H}_{90} \mathrm{~N}_{7} \mathrm{O}_{13}, 1008.6591$ ); $\Delta \mathrm{ppm}=1.19$.

Linear [Leu $]$ surfactin $n-\mathrm{C}_{13}(3 \mathrm{a})$ : HRESIMS $m / z$ found $1026.6712[\mathrm{M}+\mathrm{H}]^{+}$(calcd for $\left.\mathrm{C}_{51} \mathrm{H}_{92} \mathrm{~N}_{7} \mathrm{O}_{14}, 1026.6697\right) ; \Delta \mathrm{ppm}=$ 1.46 .

[ Leu $^{7}$ ] surfactin iso- $\mathrm{C}_{14}$ (4): off-white solid; ${ }^{1} \mathrm{H}$ and ${ }^{13} \mathrm{C}$ NMR data, Table S4; HRESIMS $\mathrm{m} / \mathrm{z}$ found 1022.6763 [M + H] ${ }^{+}$(calcd for $\left.\mathrm{C}_{52} \mathrm{H}_{92} \mathrm{~N}_{7} \mathrm{O}_{13}, 1022.6748\right) ; \Delta \mathrm{ppm}=1.47$.

Linear [ Leu $^{7}$ ] surfactin iso- $\mathrm{C}_{14}$ (4a): HRESIMS $m / z$ found $1040.6871[\mathrm{M}+\mathrm{H}]^{+}\left(\right.$calcd for $\left.\mathrm{C}_{52} \mathrm{H}_{94} \mathrm{~N}_{7} \mathrm{O}_{14}, 1040.6853\right) ; \Delta \mathrm{ppm}=$ 1.73 .

[ Leu $^{7}$ ] surfactin $n-\mathrm{C}_{14}$ (5): off-white solid; ${ }^{1} \mathrm{H}$ and ${ }^{13} \mathrm{C}$ NMR data, Table S5; HRESIMS $\mathrm{m} / z$ found $1022.6758[\mathrm{M}+\mathrm{H}]^{+}(\mathrm{calcd}$ for $\left.\mathrm{C}_{52} \mathrm{H}_{92} \mathrm{~N}_{7} \mathrm{O}_{13}, 1022.6748\right) ; \Delta p p m=0.98$.

Linear [Leu $\left.{ }^{7}\right]$ surfactin $n-\mathrm{C}_{14}(5 \mathrm{a})$ : HRESIMS $m / z$ found $1040.6871[\mathrm{M}+\mathrm{H}]^{+}$(calcd for $\left.\mathrm{C}_{52} \mathrm{H}_{94} \mathrm{~N}_{7} \mathrm{O}_{14}, 1040.6853\right) ; \Delta \mathrm{ppm}=$ 1.73 .

[ Leu $^{7}$ ] surfactin anteiso- $\mathrm{C}_{15}$ (6): off-white solid; ${ }^{1} \mathrm{H}$ and ${ }^{13} \mathrm{C}$ NMR data, Table S6; HRESIMS $\mathrm{m} / z$ found 1036.6916 [M + H] (calcd for $\mathrm{C}_{53} \mathrm{H}_{94} \mathrm{~N}_{7} \mathrm{O}_{13}, 1036.6904$ ); $\Delta \mathrm{ppm}=1.15$.

Linear [Leu $]$ s surfactin anteiso- $\mathrm{C}_{15}(6 \mathrm{6a})$ : HRESIMS $\mathrm{m} / \mathrm{z}$ found $1054.7023[\mathrm{M}+\mathrm{H}]^{+}$(calcd for $\mathrm{C}_{53} \mathrm{H}_{96} \mathrm{~N}_{7} \mathrm{O}_{14}, 1054.7010$ ); $\Delta \mathrm{ppm}=1.23$.

[ Leu $^{7}$ ] surfactin iso- $\mathrm{C}_{15}$ (7): off-white solid; ${ }^{1} \mathrm{H}$ and ${ }^{13} \mathrm{C}$ NMR data, Table S7; HRESIMS $\mathrm{m} / \mathrm{z}$ found 1036.6917 [M + H] ${ }^{+}$(calcd for $\left.\mathrm{C}_{53} \mathrm{H}_{94} \mathrm{~N}_{7} \mathrm{O}_{13}, 1036.6904\right) ; \Delta p p m=1.25$.

Mycosubtilin anteiso- $\mathrm{C}_{17}(8)$ : off-white solid; ${ }^{1 \mathrm{H}}$ and ${ }^{13} \mathrm{C}$ NMR data, Table S8; HRESIMS $\mathrm{m} / z$ found 1085.5997 [M + H] (calcd for $\mathrm{C}_{51} \mathrm{H}_{81} \mathrm{~N}_{12} \mathrm{O}_{14}, 1085.5990$ ); $\Delta \mathrm{ppm}=0.64$.

[Mycosubtilin iso- $\mathrm{C}_{17}$ (9): off-white solid; ${ }^{1} \mathrm{H}$ and ${ }^{13} \mathrm{C}$ NMR data, Table S9; HRESIMS $\mathrm{m} / \mathrm{z}$ found 1085.5996 [M + H] ${ }^{+}$(calcd for $\left.\mathrm{C}_{51} \mathrm{H}_{81} \mathrm{~N}_{12} \mathrm{O}_{14}, 1085.5990\right) ; \Delta p p m=0.55$.

Fusaricidin A (10): off-white solid; ${ }^{1} \mathrm{H}$ and ${ }^{13} \mathrm{C}$ NMR data, Table S10; HRESIMS $\mathrm{m} / z$ found 883.5627 [M $\left.+\mathrm{H}\right]^{+}$(calcd for $\left.\mathrm{C}_{41} \mathrm{H}_{75} \mathrm{~N}_{10} \mathrm{O}_{11}, 883.5611\right) ; \Delta \mathrm{ppm}=1.81$.

Fusaricidin B (11): off-white solid; HRESIMS $m / z$ found $897.5784[\mathrm{M}+\mathrm{H}]^{+}\left(\right.$calcd for $\left.\mathrm{C}_{42} \mathrm{H}_{77} \mathrm{~N}_{10} \mathrm{O}_{11}, 897.5768\right) ; \Delta \mathrm{ppm}=$ 1.78 . 


\section{Tabulated NMR Data}

Table S1. [Leu $\left.{ }^{7}\right]$ surfactin $n-C_{12}(\mathbf{1})$ NMR data.

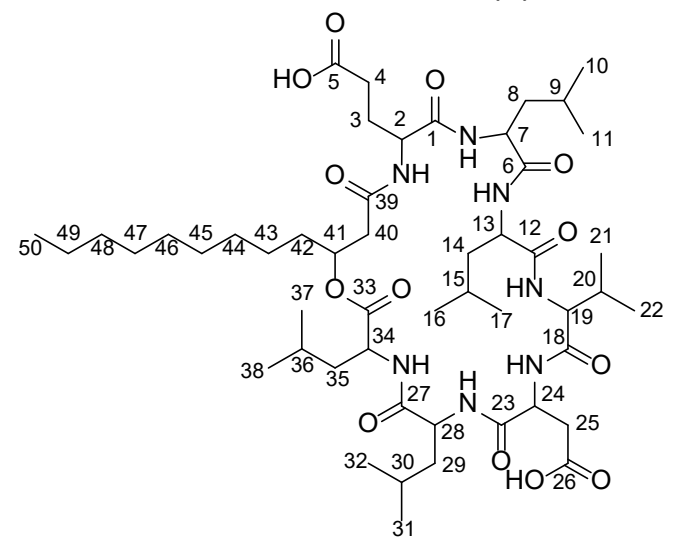

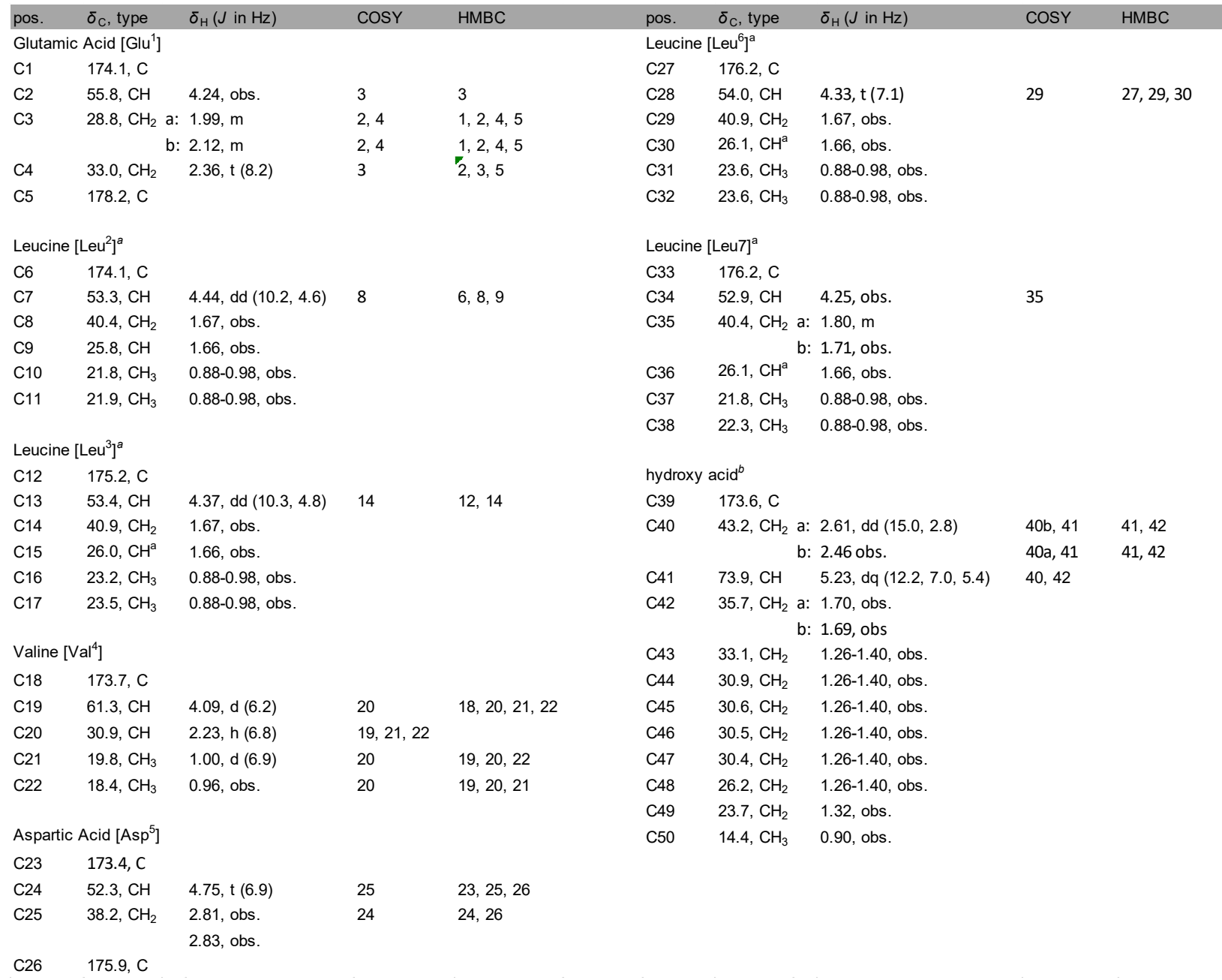

${ }^{a}$ Chemical shifts for leucine residues were assigned without taking into account configuration and are thus interchangeable. ${ }^{b}$ Chemical shifts of carbons C-43 through C-48 were arbitrarily assigned and are interchangeable. 
Table S2. [Leu $]$ surfactin anteiso- $\mathrm{C}_{13}(2) \mathrm{NMR}$ data.

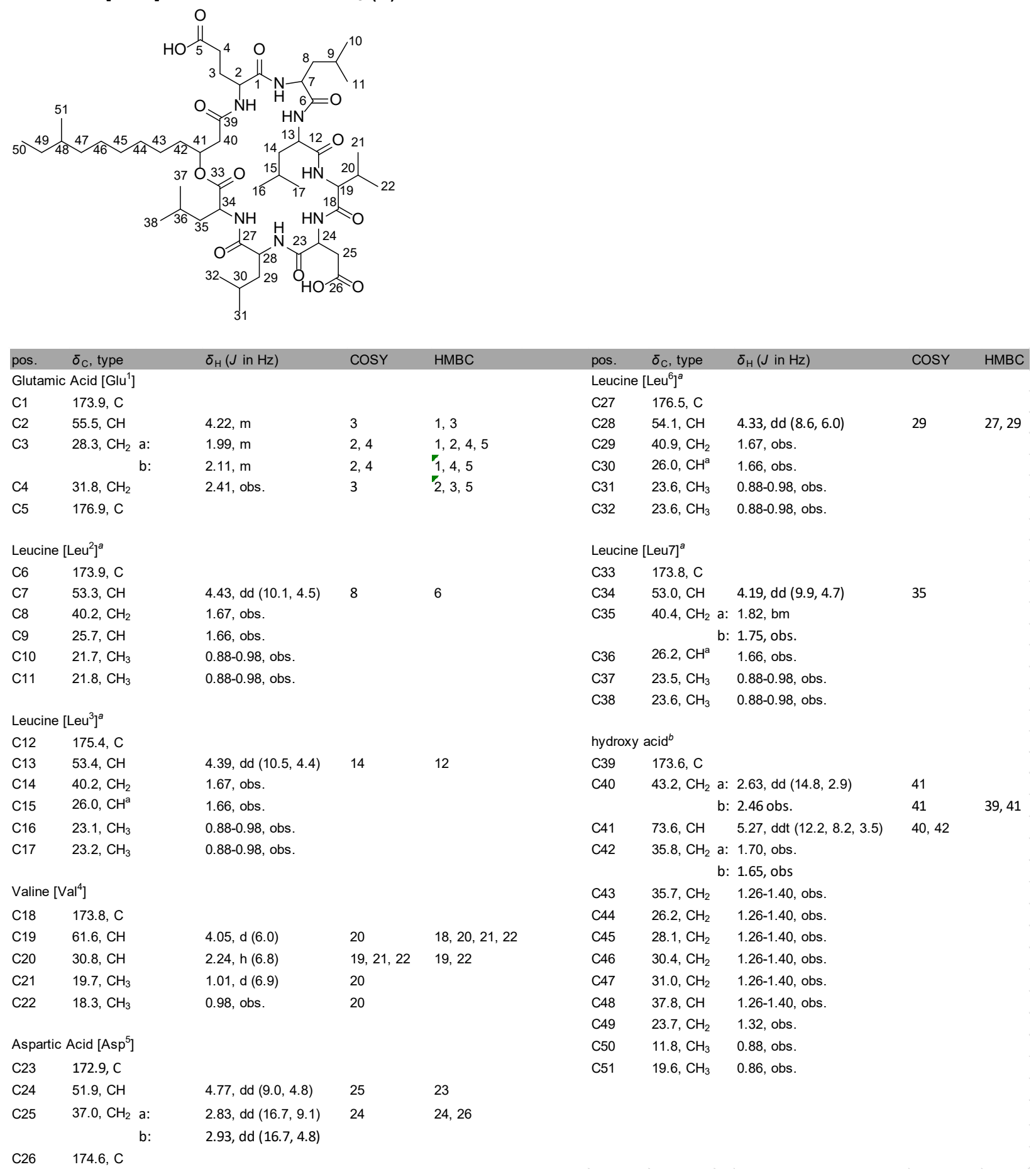

${ }^{a}$ Chemical shifts for leucine residues were assigned without taking into account configuration and are thus interchangeable. ${ }^{b}$ Chemical shifts of carbons C-43 through C-47 were arbitrarily assigned and are interchangeable. 
Table S3. [Leu $]$ surfactin $n-C_{13}$ (3) NMR data.

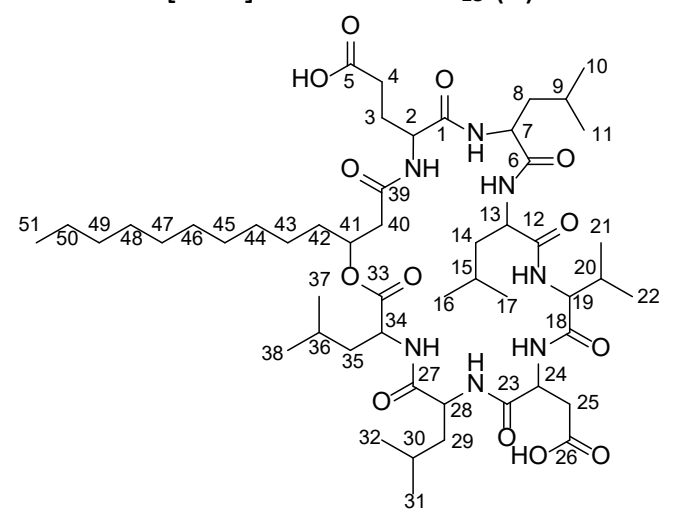

\begin{tabular}{|c|c|c|c|c|c|c|c|c|c|}
\hline pos. & $\delta_{\mathrm{C}}$, type & $\delta_{\mathrm{H}}(J$ in $\mathrm{Hz})$ & COSY & HMBC & pos. & $\delta_{\mathrm{C}}$, type & $\delta_{\mathrm{H}}(\mathrm{J}$ in $\mathrm{Hz})$ & cosy & HMBC \\
\hline \multicolumn{5}{|c|}{ Glutamic Acid [Glu $\left.{ }^{1}\right]$} & \multicolumn{5}{|c|}{ Leucine $\left[\text { Leu }^{6}\right]^{a}$} \\
\hline $\mathrm{C} 1$ & 174.1, C & & & & $\mathrm{C} 27$ & 176.1, C & & & \\
\hline $\mathrm{C} 2$ & $55.8, \mathrm{CH}$ & 4.24 , obs. & 3 & 1,3 & $\mathrm{C} 28$ & $54.0, \mathrm{CH}$ & 4.33, bt $(7.0)$ & 29 & $27,29,30$ \\
\hline \multirow[t]{2}{*}{$\mathrm{C} 3$} & 28.9, $\mathrm{CH}_{2} \mathrm{a}$ & : $1.99, \mathrm{~m}$ & 2,4 & $1,2,4,5$ & $\mathrm{C} 29$ & $40.9, \mathrm{CH}_{2}$ & 1.63 , obs. & & \\
\hline & \multicolumn{2}{|c|}{ b: $2.12, \mathrm{~m}$} & 2,4 & $1,2,4,5$ & $\mathrm{C} 30$ & $26.0, \mathrm{CH}^{\mathrm{a}}$ & 1.66 , obs. & & \\
\hline $\mathrm{C} 4$ & $33.2, \mathrm{CH}_{2}$ & 2.36, bt $(7.7)$ & 3 & $2,3,5$ & C31 & 23.2, $\mathrm{CH}_{3}$ & $0.88-0.98$, obs. & & \\
\hline C5 & $178.4, \mathrm{C}$ & & & & $\mathrm{C} 32$ & $23.5, \mathrm{CH}_{3}$ & $0.88-0.98$, obs. & & \\
\hline \multicolumn{5}{|c|}{ Leucine $\left[\mathrm{Leu}^{2}\right]^{a}$} & \multicolumn{5}{|c|}{ Leucine [Leu7] ${ }^{a}$} \\
\hline $\mathrm{C} 6$ & 174.1, C & & & & C33 & 173.5, C & & & \\
\hline $\mathrm{C} 7$ & $53.3, \mathrm{CH}$ & $4.44, \mathrm{dd}(10.1,4.6)$ & 8 & $6,8,9$ & C34 & $52.9, \mathrm{CH}$ & 4.26 , obs. & 35 & 33,35 \\
\hline $\mathrm{C} 8$ & 42.6, $\mathrm{CH}_{2}$ & 1.67, obs. & & & C35 & 40.3, $\mathrm{CH}_{2}$ & $\mathrm{a}: 1.80, \mathrm{bm}$ & & \\
\hline $\mathrm{C9}$ & $25.8, \mathrm{CH}$ & 1.66 , obs. & & & & & b: 1.71 , obs. & & \\
\hline $\mathrm{C} 10$ & $21.8, \mathrm{CH}_{3}$ & $0.88-0.98$, obs. & & & C36 & $26.1, \mathrm{CH}^{\mathrm{a}}$ & 1.66 , obs. & & \\
\hline \multirow[t]{2}{*}{ C11 } & $21.9, \mathrm{CH}_{3}$ & $0.88-0.98$, obs. & & & C37 & 23.6, $\mathrm{CH}_{3}$ & $0.88-0.98$, obs. & & \\
\hline & & & & & C38 & 23.6, $\mathrm{CH}_{3}$ & $0.88-0.98$, obs. & & \\
\hline \multicolumn{10}{|c|}{ Leucine $\left[\text { Leu }^{3}\right]^{a}$} \\
\hline $\mathrm{C} 12$ & $175.3, \mathrm{C}$ & & & & \multicolumn{5}{|c|}{ hydroxy acid $^{b}$} \\
\hline $\mathrm{C} 13$ & $53.4, \mathrm{CH}$ & $4.36, \mathrm{dd}(10.5,4.7)$ & 14 & $12,14,15$ & C39 & 173.6, C & & & \\
\hline $\mathrm{C} 14$ & $40.4, \mathrm{CH}_{2}$ & 1.70 , obs. & & & $\mathrm{C} 40$ & 43.2, $\mathrm{CH}_{2}$ & a: 2.61 , dd $(14.5,3.0)$ & 41 & $39,41,42$ \\
\hline C15 & $26.1, \mathrm{CH}^{\mathrm{a}}$ & 1.66 , obs. & & & & & b: $2.46, \mathrm{dd}(14.5,9.1)$ & 41 & $39,41,42$ \\
\hline $\mathrm{C} 16$ & $21.9, \mathrm{CH}_{3}$ & $0.88-0.98$, obs. & & & C41 & $74.0, \mathrm{CH}$ & $5.22, \mathrm{bm}$ & 40,42 & \\
\hline $\mathrm{C} 17$ & $22.4, \mathrm{CH}_{3}$ & $0.88-0.98$, obs. & & & $\mathrm{C} 42$ & 35.7, $\mathrm{CH}_{2}$ & $\begin{array}{l}\text { a: } 1.71 \text {, obs. } \\
\text { b: } 1.65 \text {, obs }\end{array}$ & & \\
\hline \multicolumn{5}{|c|}{ Valine $\left[\left.V\right|^{4}\right]$} & $\mathrm{C} 43$ & 33.1, $\mathrm{CH}_{2}$ & 1.29 , obs. & & \\
\hline C18 & 173.7, C & & & & $\mathrm{C} 44$ & $30.8, \mathrm{CH}_{2}$ & 1.26-1.40, obs. & & \\
\hline C19 & $61.3, \mathrm{CH}$ & $4.09, \mathrm{~d}(6.2)$ & 20 & $18,20,21,22$ & C45 & $30.7, \mathrm{CH}_{2}$ & 1.26-1.40, obs. & & \\
\hline $\mathrm{C} 20$ & $30.9, \mathrm{CH}$ & $2.24, \mathrm{~h}(6.9)$ & $19,21,22$ & $19,21,22$ & C46 & $30.6, \mathrm{CH}_{2}$ & 1.26-1.40, obs. & & \\
\hline $\mathrm{C} 21$ & $19.9, \mathrm{CH}_{3}$ & $1.00, \mathrm{~d}(6.9)$ & 20 & $19,20,22$ & $\mathrm{C} 47$ & $30.5, \mathrm{CH}_{2}$ & 1.26-1.40, obs. & & \\
\hline \multirow[t]{2}{*}{$\mathrm{C} 22$} & $18.4, \mathrm{CH}_{3}$ & 0.98, obs. & 20 & $19,20,21$ & $\mathrm{C} 48$ & $30.4, \mathrm{CH}_{2}$ & 1.26-1.40, obs. & & \\
\hline & & & & & C49 & $26.2, \mathrm{CH}_{2}$ & 1.26-1.40, obs. & & \\
\hline \multicolumn{5}{|c|}{ Aspartic Acid $\left[\mathrm{Asp}^{5}\right]$} & C50 & 23.7, $\mathrm{CH}_{2}$ & 1.26-1.40, obs. & & \\
\hline $\mathrm{C} 23$ & 173.6, C & & & & C51 & $14.4, \mathrm{CH}_{3}$ & 0.90 , obs. & & \\
\hline $\mathrm{C} 24$ & $52.4, \mathrm{CH}$ & 4.75, bt $(6.7)$ & 25 & $23,25,26$ & & & & & \\
\hline $\mathrm{C} 25$ & $38.4, \mathrm{CH}_{2} \mathrm{a}$ & $\begin{array}{l}2.80, \text { obs. } \\
: 2.81, \text { obs. }\end{array}$ & 24 & $23,24,26$ & & & & & \\
\hline $\mathrm{C} 26$ & 176.1, C & & & & & & & & \\
\hline
\end{tabular}

${ }^{a}$ Chemical shifts for leucine residues were assigned without taking into account configuration and are thus interchangeable. ${ }^{b}$ Chemical shifts of carbons C-43 through C-50 were arbitrarily assigned and are interchangeable. 
Table S4. $\left[\right.$ Leu $\left.^{7}\right]$ surfactin iso- $\mathrm{C}_{14}(4)$ NMR data.

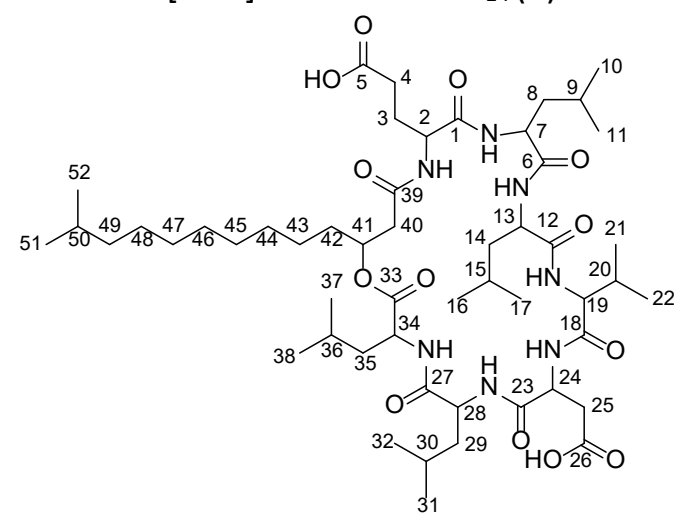

\begin{tabular}{|c|c|c|c|c|c|c|c|c|c|}
\hline pos. & $\delta_{\mathrm{C}}$, type & $\delta_{\mathrm{H}}(J$ in $\mathrm{Hz})$ & COSY & HMBC & pos. & $\delta_{\mathrm{C}}$, type & $\delta_{\mathrm{H}}(J$ in $\mathrm{Hz})$ & COSY & HMBC \\
\hline \multicolumn{5}{|c|}{ Glutamic Acid $\left[\mathrm{Glu}^{1}\right]$} & \multicolumn{5}{|c|}{ Leucine $\left[\text { Leu }^{6}\right]^{a}$} \\
\hline $\mathrm{C} 1$ & 173.8, C & & & & $\mathrm{C} 27$ & 176.4, C & & & \\
\hline $\mathrm{C} 2$ & $55.3, \mathrm{CH}$ & $4.23, \mathrm{~m}$ & 3 & $1,3,4$ & $\mathrm{C} 28$ & $54.1, \mathrm{CH}$ & $4.33, \mathrm{dd}(8.6,4.8)$ & 29 & $27,29,30$ \\
\hline \multirow[t]{2}{*}{$\mathrm{C} 3$} & 28.5, $\mathrm{CH}_{2}$ a: & $1.98, \mathrm{~m}$ & 2,4 & $1,2,4,5$ & $\mathrm{C} 29$ & $40.9, \mathrm{CH}_{2}$ & 1.67 , obs. & & \\
\hline & b: & $2.11, \mathrm{~m}$ & 2,4 & $1,2,4,5$ & $\mathrm{C} 30$ & $26.0, \mathrm{CH}^{\mathrm{a}}$ & 1.66 , obs. & & \\
\hline $\mathrm{C} 4$ & $31.8, \mathrm{CH}_{2}$ & 2.41 , obs. & 3 & $2,3,5$ & C31 & 23.2, $\mathrm{CH}_{3}$ & $0.88-0.98$, obs. & & \\
\hline C5 & 176.9, C & & & & $\mathrm{C} 32$ & 23.5, $\mathrm{CH}_{3}$ & $0.88-0.98$, obs. & & \\
\hline \multicolumn{5}{|c|}{ Leucine $\left[\operatorname{Leu}^{2}\right]^{\mathrm{a}}$} & \multicolumn{5}{|c|}{ Leucine [Leu7] $^{a}$} \\
\hline C6 & 173.9, C & & & & $\mathrm{C} 33$ & 173.9, C & & & \\
\hline $\mathrm{C} 7$ & $53.3, \mathrm{CH}$ & $4.43, \mathrm{dd}(10.0,4.9)$ & 8 & $6,8,9$ & $\mathrm{C} 34$ & $53.0, \mathrm{CH}$ & $4.19, \mathrm{dd}(9.9,4.7)$ & 35 & \\
\hline \multirow[t]{2}{*}{$\mathrm{C} 8$} & 42.8, $\mathrm{CH}_{2}$ a: & 1.57 , obs. & & & C35 & $40.4, \mathrm{CH}_{2}$ & $\mathrm{a}: 1.80, \mathrm{bm}$ & & \\
\hline & $b:$ & 1.70, obs. & & & & & b: 1.75 , obs. & & \\
\hline $\mathrm{C9}$ & $25.7, \mathrm{CH}$ & 1.66, obs. & & & $\mathrm{C} 36$ & $26.1, \mathrm{CH}^{\mathrm{a}}$ & 1.66 , obs. & & \\
\hline $\mathrm{C} 10$ & $21.8, \mathrm{CH}_{3}$ & $0.88-0.98$, obs. & & & $\mathrm{C} 37$ & 23.6, $\mathrm{CH}_{3}$ & $0.88-0.98$, obs. & & \\
\hline C11 & $21.8, \mathrm{CH}_{3}$ & $0.88-0.98$, obs. & & & C38 & 23.6, $\mathrm{CH}_{3}$ & $0.88-0.98$, obs. & & \\
\hline \multicolumn{5}{|c|}{ Leucine $\left[\operatorname{Leu}^{3}\right]^{a}$} & \multicolumn{5}{|c|}{ hydroxy $\operatorname{acid}^{b}$} \\
\hline $\mathrm{C} 12$ & $175.4, \mathrm{C}$ & & & & C39 & 173.6, C & & & \\
\hline $\mathrm{C} 13$ & $53.3, \mathrm{CH}$ & $4.38, \mathrm{dd}(9.9,4.7)$ & 14 & 12,14 & $\mathrm{C} 40$ & 43.2, $\mathrm{CH}_{2}$ & a: 2.62 , dd $(14.8,3.0)$ & 41 & 39,41 \\
\hline C14 & $40.2, \mathrm{CH}_{2}$ & 1.67 , obs. & & & & & b: 2.46 obs. & 41 & $39,41,42$ \\
\hline C15 & $26.0, \mathrm{CH}^{\mathrm{a}}$ & 1.66, obs. & & & $\mathrm{C} 41$ & 73.7, $\mathrm{CH}$ & $5.25, \mathrm{dt}(8.7,4.5)$ & 40,42 & \\
\hline C16 & $21.9, \mathrm{CH}_{3}$ & $0.88-0.98$, obs. & & & $\mathrm{C} 42$ & $35.7, \mathrm{CH}_{2}$ & a: 1.68, obs. & & \\
\hline \multirow[t]{2}{*}{$\mathrm{C} 17$} & $22.3, \mathrm{CH}_{3}$ & $0.88-0.98$, obs. & & & & & b: 1.68, obs & & \\
\hline & & & & & $\mathrm{C} 43$ & 33.3, $\mathrm{CH}_{2}$ & 1.26-1.40, obs. & & \\
\hline \multicolumn{5}{|c|}{ Valine $\left[\mathrm{Val}^{4}\right]$} & $\mathrm{C} 44$ & $30.8, \mathrm{CH}_{2}$ & 1.26-1.40, obs. & & \\
\hline C18 & 173.8, C & & & & C45 & $30.7, \mathrm{CH}_{2}$ & 1.26-1.40, obs. & & \\
\hline C19 & $61.5, \mathrm{CH}$ & $4.06, d(6.1)$ & 20 & $18,20,21,22$ & $\mathrm{C} 46$ & $30.3, \mathrm{CH}_{2}$ & 1.26-1.40, obs. & & \\
\hline $\mathrm{C} 20$ & $30.6, \mathrm{CH}$ & $2.24, \mathrm{~h}(6.8)$ & $19,21,22$ & 19,22 & $\mathrm{C} 47$ & 28.3, $\mathrm{CH}_{2}$ & $1.26-1.40$, obs. & & \\
\hline $\mathrm{C} 21$ & 19.7, $\mathrm{CH}_{3}$ & $1.00, \mathrm{~d}(6.9)$ & 20 & $19,20,22$ & C48 & $31.0, \mathrm{CH}_{2}$ & 1.26-1.40, obs. & & \\
\hline \multirow[t]{2}{*}{$\mathrm{C} 22$} & $18.4, \mathrm{CH}_{3}$ & 0.97 , obs. & 20 & $19,20,21$ & $\mathrm{C} 49$ & $40.2, \mathrm{CH}_{2}$ & 1.17 , obs. & 50 & $48,50,51$ \\
\hline & & & & & $\mathrm{C} 50$ & $29.1, \mathrm{CH}$ & $1.52, \mathrm{~m}$ & $49,51,52$ & $49,51,52$ \\
\hline \multicolumn{5}{|c|}{ Aspartic Acid $\left[\mathrm{Asp}^{5}\right]$} & $\mathrm{C} 51$ & 23.1, $\mathrm{CH}_{3}$ & $0.88, d(6.6)$ & 50 & $49,50,52$ \\
\hline $\mathrm{C} 23$ & $172.9, \mathrm{C}$ & & & & $\mathrm{C} 52$ & $23.1, \mathrm{CH}_{3}$ & $0.88, d(6.6)$ & 50 & $49,50,51$ \\
\hline $\mathrm{C} 24$ & $51.9, \mathrm{CH}$ & $4.76, \mathrm{dd}(9.0,4.8)$ & 25 & $23,25,26$ & & & & & \\
\hline \multirow[t]{2}{*}{$\mathrm{C} 25$} & 37.0, $\mathrm{CH}_{2}$ a: & $2.83, \mathrm{dd}(16.7,9.0)$ & 24 & $23,24,26$ & & & & & \\
\hline & $\mathrm{b}:$ & $2.93, \mathrm{dd}(16.7,4.8)$ & 24 & $23,24,26$ & & & & & \\
\hline $\mathrm{C} 26$ & 174.6, C & & & & & & & & \\
\hline
\end{tabular}

${ }^{a}$ Chemical shifts for leucine residues were assigned without taking into account configuration and are thus interchangeable. ${ }^{b}$ Chemical shifts of carbons C-43 through C-48 were arbitrarily assigned and are interchangeable. 
Table S5. [Leu $]$ surfactin $n-C_{14}(5)$ NMR data.

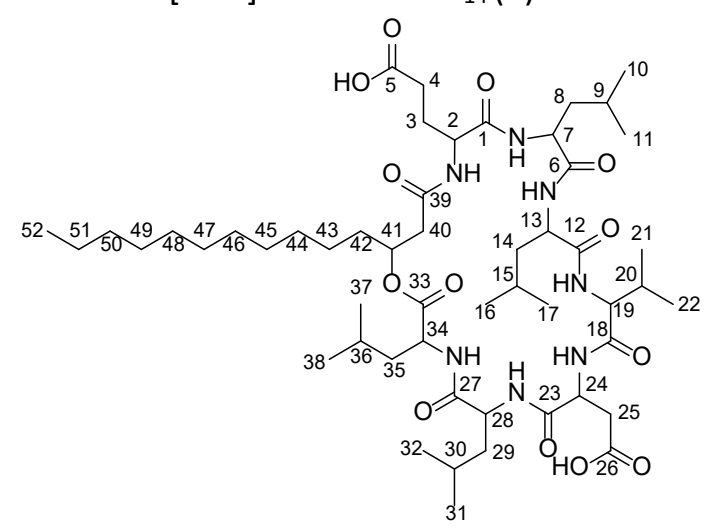

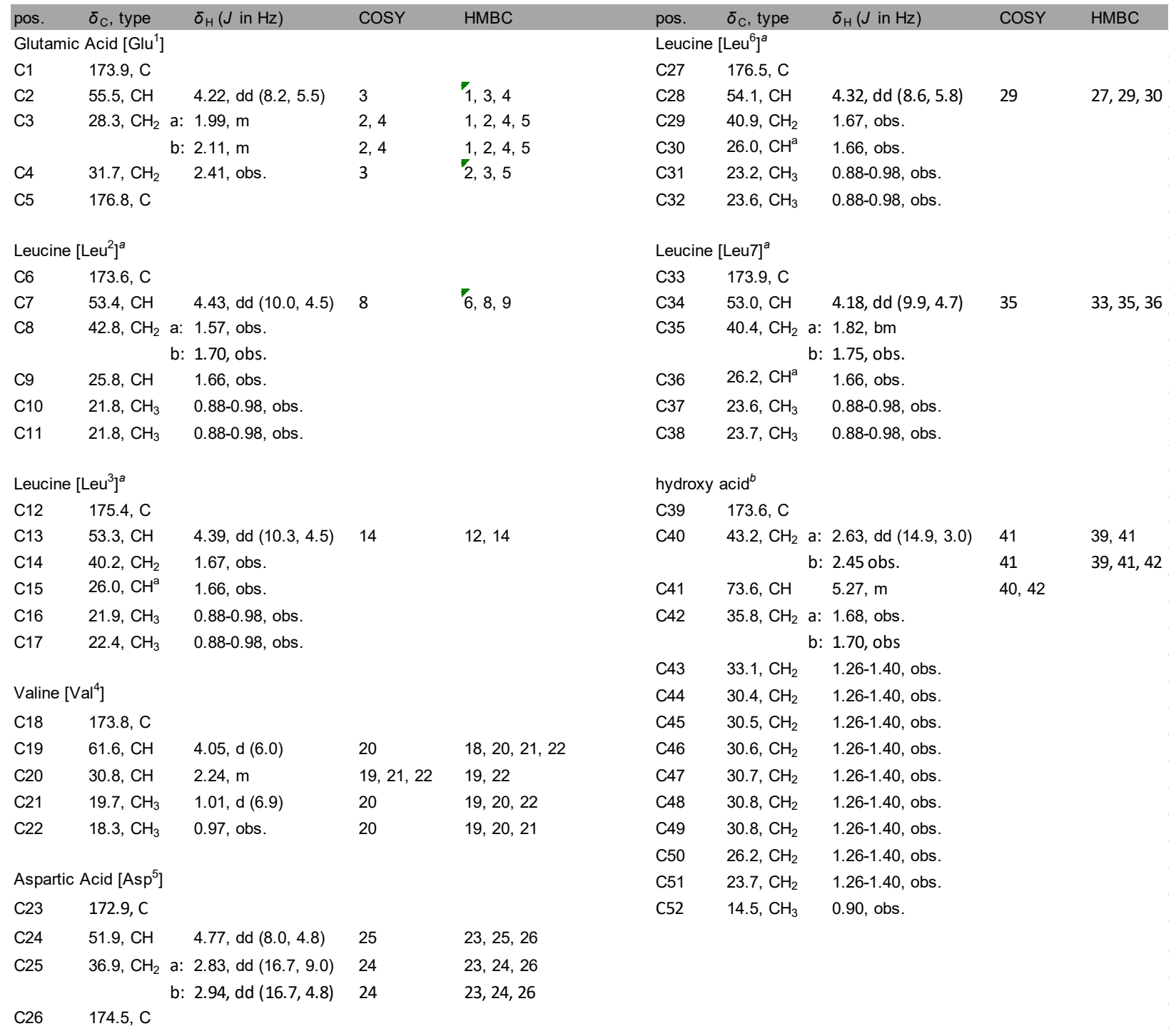

${ }^{a}$ Chemical shifts for leucine residues were assigned without taking into account configuration and are thus interchangeable. ${ }^{b}$ Chemical shifts of carbons C-43 through C-50 were arbitrarily assigned and are interchangeable. 
Table S6. [Leu $]$ surfactin anteiso- $\mathrm{C}_{15}(\mathbf{6})$ NMR data.

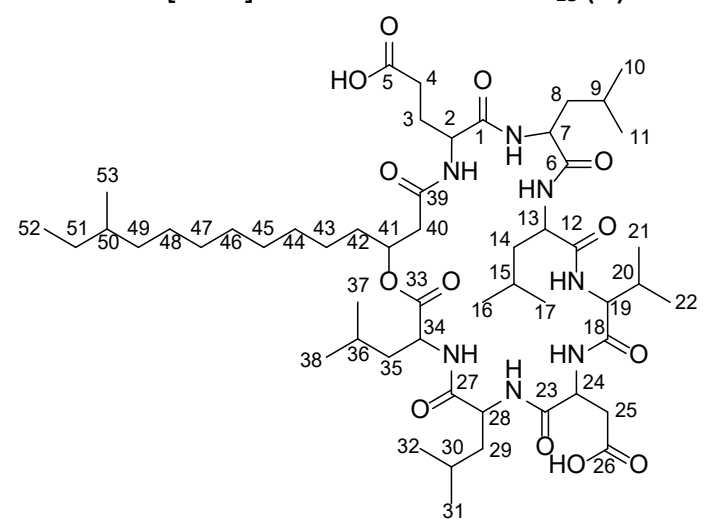

\begin{tabular}{|c|c|c|c|c|c|c|c|c|c|}
\hline pos. & $\delta_{C}$, type & $\delta_{\mathrm{H}}(\mathrm{J}$ in $\mathrm{Hz})$ & COSY & HMBC & pos. & $\delta_{\mathrm{C}}$, type & $\delta_{\mathrm{H}}(\mathrm{J}$ in $\mathrm{Hz})$ & cosy & HMBC \\
\hline \multicolumn{5}{|c|}{ Glutamic Acid [Glu $\left.{ }^{1}\right]$} & \multicolumn{5}{|c|}{ Leucine $\left[\mathrm{Leu}^{6}\right]^{a}$} \\
\hline $\mathrm{C} 1$ & $174.1, \mathrm{C}$ & & & & $\mathrm{C} 27$ & 175.3, C & & & \\
\hline $\mathrm{C} 2$ & $55.8, \mathrm{CH}$ & 4.23 , obs. & 3 & & $\mathrm{C} 28$ & $54.0, \mathrm{CH}$ & 4.34 , obs. & 29 & $27,29,30$ \\
\hline \multirow[t]{2}{*}{ C3 } & $29.0, \mathrm{CH}_{2} \mathrm{a}$ & a: $1.98, \mathrm{~m}$ & 2,4 & 2 & $\mathrm{C} 29$ & $40.8, \mathrm{CH}_{2}$ & 1.67 , obs. & & \\
\hline & & b: $2.12, \mathrm{~m}$ & 2,4 & 2 & $\mathrm{C} 30$ & $26.2, \mathrm{CH}^{\mathrm{a}}$ & 1.66, obs. & & \\
\hline $\mathrm{C} 4$ & 33.3, $\mathrm{CH}_{2}$ & 2.35 , obs. & 3 & $2,3,5$ & C31 & 23.1, $\mathrm{CH}_{3}$ & $0.88-0.98$, obs. & & \\
\hline C5 & $178.4, \mathrm{C}$ & & & & $\mathrm{C} 32$ & 23.2, $\mathrm{CH}_{3}$ & $0.88-0.98$, obs. & & \\
\hline \multicolumn{5}{|c|}{ Leucine $\left[\mathrm{Leu}^{2}\right]^{a}$} & \multicolumn{5}{|c|}{ Leucine [Leu7] $^{a}$} \\
\hline C6 & $174.1, \mathrm{C}$ & & & & C33 & 173.7, C & & & \\
\hline $\mathrm{C} 7$ & $53.4, \mathrm{CH}$ & $4.45, \mathrm{dd}(10.0,4.5)$ & 8 & 6 & C34 & $52.9, \mathrm{CH}$ & 4.26 , obs. & 35 & \\
\hline \multirow[t]{2}{*}{$\mathrm{C} 8$} & 42.6, $\mathrm{CH}_{2}$ & a: 1.57 , obs. & & & C35 & $40.4, \mathrm{CH}_{2}$ & a: $1.80, \mathrm{bm}$ & & \\
\hline & & b: 1.70, obs. & & & & & b: 1.71 , obs. & & \\
\hline C9 & $25.8, \mathrm{CH}$ & 1.66 , obs. & & & C36 & $26.1, \mathrm{CH}^{\mathrm{a}}$ & 1.66, obs. & & \\
\hline $\mathrm{C} 10$ & 21.7, $\mathrm{CH}_{3}$ & $0.88-0.98$, obs. & & & $\mathrm{C} 37$ & $23.5, \mathrm{CH}_{3}$ & $0.88-0.98$, obs. & & \\
\hline C11 & $21.9, \mathrm{CH}_{3}$ & $0.88-0.98$, obs. & & & $\mathrm{C} 38$ & 23.6, $\mathrm{CH}_{3}$ & $0.88-0.98$, obs. & & \\
\hline \multicolumn{5}{|c|}{ Leucine $\left[\mathrm{Leu}^{3}\right]^{a}$} & \multicolumn{5}{|c|}{ hydroxy acid ${ }^{b}$} \\
\hline C12 & 175.3, C & & & & C39 & 173.6, C & & & \\
\hline $\mathrm{C} 13$ & $53.3, \mathrm{CH}$ & $4.36, \mathrm{dd}(10.3,4.5)$ & 14 & 14 & $\mathrm{C} 40$ & 43.2, $\mathrm{CH}_{2}$ & a: 2.61 , dd $(14.5,3.0)$ & 41 & 39 \\
\hline C14 & 40.3, $\mathrm{CH}_{2}$ & 1.67 , obs. & & & & & b: $2.45, \mathrm{dd}(14.5,9.0)$ & 41 & 39 \\
\hline C15 & 26.0, $\mathrm{CH}^{\mathrm{a}}$ & 1.66, obs. & & & $\mathrm{C} 41$ & $73.9, \mathrm{CH}$ & $5.22, \mathrm{~m}$ & 40,42 & \\
\hline C16 & $21.9, \mathrm{CH}_{3}$ & $0.88-0.98$, obs. & & & $\mathrm{C} 42$ & $35.7, \mathrm{CH}_{2}$ & a: 1.65 , obs. & & \\
\hline \multirow[t]{2}{*}{ C17 } & $22.4, \mathrm{CH}_{3}$ & $0.88-0.98$, obs. & & & & & b: 1.68, obs & & \\
\hline & & & & & $\mathrm{C} 43$ & $35.7, \mathrm{CH}_{2}$ & 1.26-1.40, obs. & & \\
\hline \multicolumn{3}{|c|}{ Valine $\left[\mathrm{Val}^{4}\right]$} & & & $\mathrm{C} 44$ & $30.4, \mathrm{CH}_{2}$ & 1.26-1.40, obs. & & \\
\hline C18 & 173.7, C & & & & $\mathrm{C} 45$ & $30.6, \mathrm{CH}_{2}$ & 1.26-1.40, obs. & & \\
\hline C19 & $61.3, \mathrm{CH}$ & $4.09, \mathrm{~d}(6.2)$ & 20 & $18,20,21,22$ & $\mathrm{C} 46$ & $30.6, \mathrm{CH}_{2}$ & 1.26-1.40, obs. & & \\
\hline $\mathrm{C} 20$ & $30.9, \mathrm{CH}$ & $2.23, \mathrm{~m}$ & $19,21,22$ & 19,22 & $\mathrm{C} 47$ & $30.7, \mathrm{CH}_{2}$ & 1.26-1.40, obs. & & \\
\hline $\mathrm{C} 21$ & $19.9, \mathrm{CH}_{3}$ & $1.00, d(6.9)$ & 20 & $19,20,22$ & $\mathrm{C} 48$ & $31.1, \mathrm{CH}_{2}$ & 1.26-1.40, obs. & & \\
\hline \multirow[t]{2}{*}{$\mathrm{C} 22$} & $18.4, \mathrm{CH}_{3}$ & 0.95, obs. & 20 & $19,20,21$ & $\mathrm{C} 49$ & 28.2, $\mathrm{CH}_{2}$ & 1.26-1.40, obs. & & \\
\hline & & & & & C50 & $35.7, \mathrm{CH}$ & 1.26-1.40, obs. & & \\
\hline \multicolumn{5}{|c|}{ Aspartic Acid $\left[\mathrm{Asp}^{5}\right]$} & C51 & 23.6, $\mathrm{CH}_{2}$ & 1.26-1.40, obs. & & \\
\hline $\mathrm{C} 23$ & $173.5, \mathrm{C}$ & & & & C52 & $11.8, \mathrm{CH}_{3}$ & 0.86, obs. & & \\
\hline $\mathrm{C} 24$ & $52.4, \mathrm{CH}$ & $4.75, \mathrm{t}(6.8)$ & 25 & $23,25,26$ & C53 & $19.6, \mathrm{CH}_{3}$ & 0.84, obs. & & \\
\hline $\mathrm{C} 25$ & $38.4, \mathrm{CH}_{2}$ & $2.80, \mathrm{~m}$ & 24 & $23,24,26$ & & & & & \\
\hline $\mathrm{C} 26$ & 176.1, C & & & & & & & & \\
\hline
\end{tabular}

${ }^{a}$ Chemical shifts for leucine residues were assigned without taking into account configuration and are thus interchangeable. ${ }^{b}$ Chemical shifts of carbons C-43 through C-51 were arbitrarily assigned and are interchangeable. 
Table S7. [Leu $\left.{ }^{7}\right]$ surfactin iso- $\mathrm{C}_{15}$ (7) NMR data.

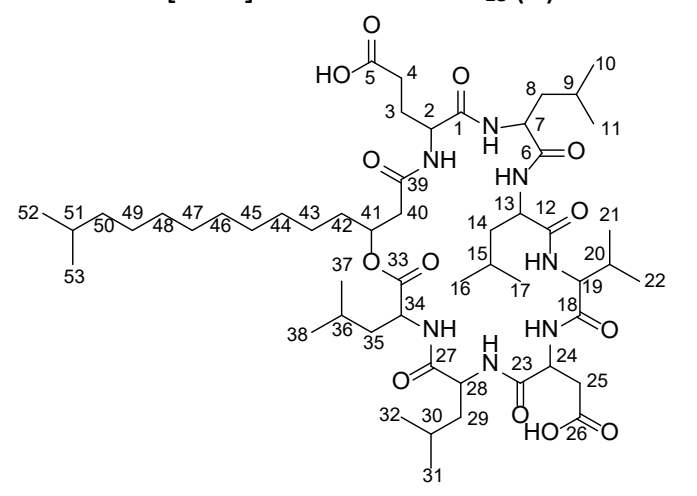

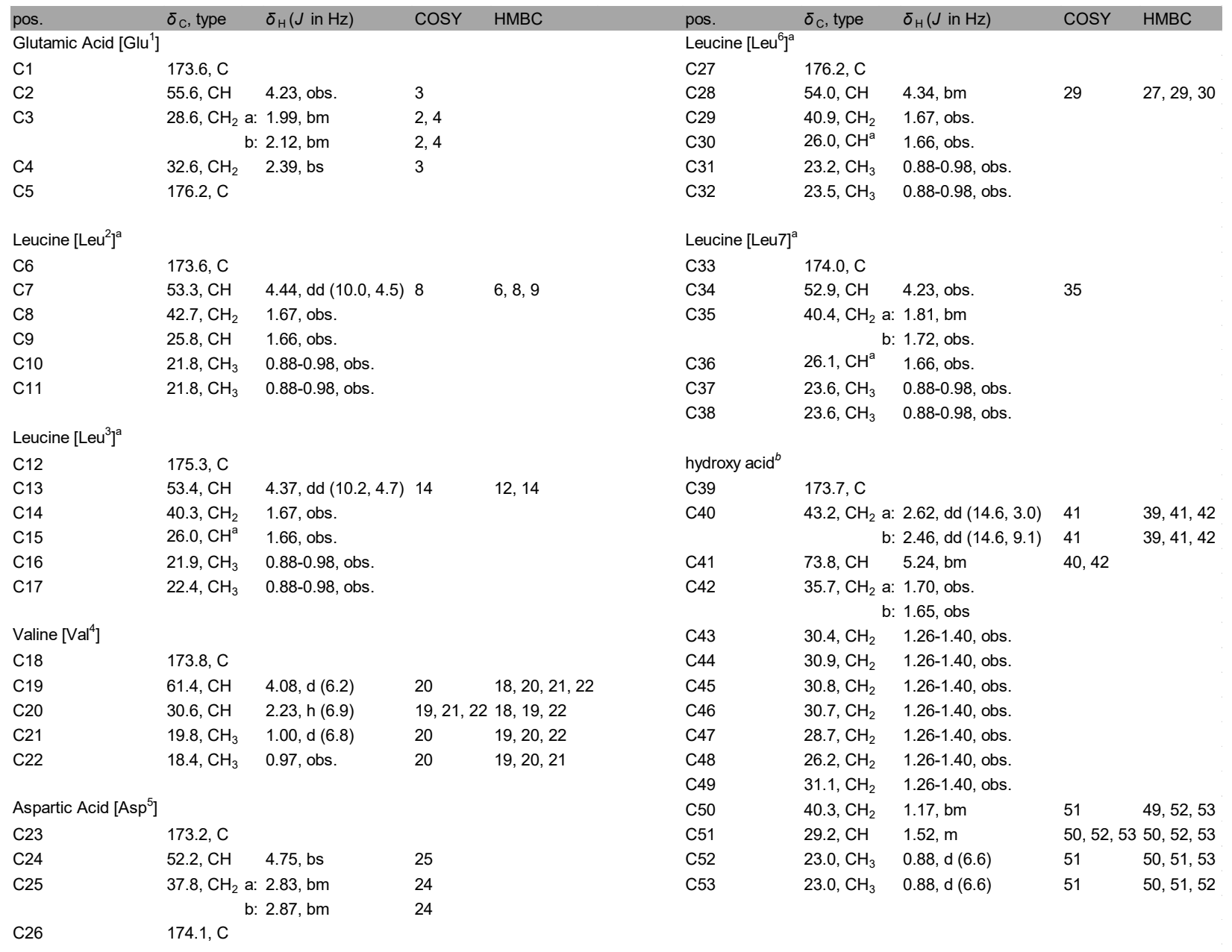

${ }^{a}$ Chemical shifts for leucine residues were assigned without considering configuration and are thus interchangeable. ${ }^{b}$ Chemical shifts of carbons C-43 through C-49 were arbitrarily assigned and are interchangeable. 
Table S8. Mycosubtilin anteiso- $\mathrm{C}_{17}(8)$ NMR data.

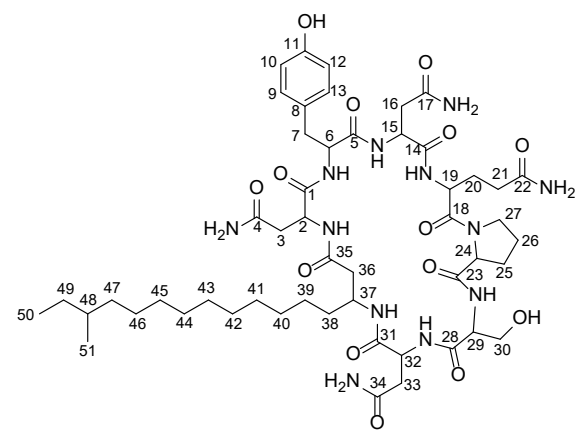

\begin{tabular}{|c|c|c|c|c|c|c|c|c|c|}
\hline pos. & $\delta_{\mathrm{C}}$, type & $\delta_{H}(J$ in $\mathrm{Hz})$ & COSY & $\mathrm{HMBC}$ & pos. & $\delta_{\mathrm{C}}$, type & $\delta_{H}(J$ in $\mathrm{Hz})$ & cosY & $\mathrm{HMBC}$ \\
\hline Asparagine $\left[\operatorname{Asn}^{1}\right]^{a}$ & & & & & Serine [S & & & & \\
\hline $\mathrm{C} 1$ & 173.0, C & & & & $\mathrm{C} 28$ & 170.0, C & & & \\
\hline $\mathrm{C} 2$ & $50.8, \mathrm{CH}$ & 4.40, obs. & 3 & 3 & $\mathrm{C} 29$ & $54.7, \mathrm{CH}$ & $4.19, q(6.5)$ & 30 & $23,28,30$ \\
\hline C3 & $36.2, \mathrm{CH}_{2}$ & $2.53, \mathrm{~m}$ & 2 & 2,4 & $\mathrm{C} 30$ & $60.5, \mathrm{CH}_{2}$ a: & 3.60, obs. & 29 & 28,29 \\
\hline $\mathrm{C} 4$ & $171.3, \mathrm{CH}$ & & & & & $\mathrm{b}$ : & 3.64, obs. & 29 & 28,29 \\
\hline $\mathrm{NH}-2$ & & 8.09, obs. & 2 & & $\mathrm{NH}-29$ & & 8.75, bs & 29 & \\
\hline \multirow[t]{2}{*}{$\mathrm{NH}_{2}-4$} & & $7.29,6.93$ & & & & & & & \\
\hline & & & & & \multicolumn{3}{|c|}{ Asparagine $\left[\mathrm{Asn}^{7}\right]^{a}$} & & \\
\hline Tyrosine $\left[\right.$ Tyr $\left.^{2}\right]$ & & & & & $\mathrm{C} 31$ & 170.6, C & & & \\
\hline C5 & $171.2, \mathrm{C}$ & & & & $\mathrm{C} 32$ & $50.1, \mathrm{CH}$ & $4.60, \operatorname{td}(8.2,6.0)$ & $33, \mathrm{NH}-32$ & 31,33 \\
\hline C6 & $56.5, \mathrm{CH}$ & $4.02, \mathrm{dt}(10.0,4.4)$ & 7 & 5,7 & C33 & 37.3, $\mathrm{CH}_{2}$ a: & $2.64, \mathrm{dd}(15.5,6.0)$ & $32,33 b$ & 32,34 \\
\hline \multirow[t]{2}{*}{$\mathrm{C7}$} & 35.1, $\mathrm{CH}_{2}$ a: & $2.76, \mathrm{dd}(14.2,10.0)$ & 6 & $5,6,8,9,13$ & & $\mathrm{~b}$ & 2.26, obs. & $32,33 a$ & 32,34 \\
\hline & b: & $2.92, \mathrm{dd}(14.2,4.4)$ & & $5,6,8,9,14$ & $\mathrm{C} 34$ & $171.3, \mathrm{C}$ & & & \\
\hline C8 & $127.9, \mathrm{C}$ & & & & $\mathrm{NH}-32$ & & $7.84, \mathrm{~d}(8.2)$ & 32 & 28 \\
\hline C9 & $129.8, \mathrm{CH}$ & $7.01, \mathrm{~d}(8.2)$ & 10 & $7,11,13$ & $\mathrm{NH}_{2}-34$ & & $7.24,6.88$ & & 33,34 \\
\hline $\mathrm{C} 10$ & $115.1, \mathrm{CH}$ & $6.65, \mathrm{~d}(8.2)$ & 9 & $8,11,12$ & & & & & \\
\hline C11 & $155.9, \mathrm{C}$ & & & & lipid tail ${ }^{b}$ & & & & \\
\hline $\mathrm{C} 12$ & $115.1, \mathrm{CH}$ & $6.65, \mathrm{~d}(8.2)$ & 13 & $8,10,11$ & $\mathrm{C} 35$ & $171.2, \mathrm{C}$ & & & \\
\hline $\mathrm{C} 13$ & $129.8, \mathrm{CH}$ & $7.01, \mathrm{~d}(8.2)$ & 12 & $7,9,11$ & C36 & 41.3, $\mathrm{CH}_{2}$ & 2.32, obs. & 37 & 35 \\
\hline \multirow[t]{2}{*}{$\mathrm{NH}-6$} & & 8.60, bd & 6 & 1 & $\mathrm{C} 37$ & $46.4, \mathrm{CH}$ & $3.94, \mathrm{~m}$ & $36,38, \mathrm{NH}-37$ & \\
\hline & & & & & C38 & $34.5, \mathrm{CH}_{2}$ a: & $1.42, \mathrm{~m}$ & 37 & \\
\hline \multicolumn{2}{|l|}{ Asparagine $\left[\mathrm{Asn}^{3}\right]^{a}$} & & & & & $\mathrm{~b}:$ & $1.38, \mathrm{~m}$ & 37 & 37 \\
\hline C14 & $171.2, \mathrm{C}$ & & & & C39 & 25.6, $\mathrm{CH}_{2}$ & 1.12-1.28, obs & & \\
\hline C15 & $50.5, \mathrm{CH}$ & 4.40, obs. & & & $\mathrm{C} 40$ & $28.9, \mathrm{CH}_{2}$ & 1.12-1.28, obs & & \\
\hline \multirow[t]{2}{*}{ C16 } & $36.5, \mathrm{CH}_{2}$ a: & 2.31, obs. & & & $\mathrm{C} 41$ & $29.5, \mathrm{CH}_{2}$ & 1.12-1.28, obs & & \\
\hline & $\mathrm{b}:$ & 2.25, obs. & & & $\mathrm{C} 42$ & $29.2, \mathrm{CH}_{2}$ & $1.12-1.28$, obs & & \\
\hline C17 & 173.0, C & & & & $\mathrm{C} 43$ & 28.9, $\mathrm{CH}_{2}$ & 1.12-1.28, obs & & \\
\hline $\mathrm{NH}-15$ & & 8.06, obs. & & & $\mathrm{C} 44$ & $29.1, \mathrm{CH}_{2}$ & $1.12-1.28$, obs & & \\
\hline \multirow[t]{2}{*}{$\mathrm{NH}_{2}-17$} & & $7.27,6.90$ & & & $\mathrm{C} 45$ & 29.2, $\mathrm{CH}_{2}$ & 1.12-1.28, obs & & \\
\hline & & & & & $\mathrm{C} 46$ & $29.2, \mathrm{CH}_{2}$ & 1.12-1.28, obs & & \\
\hline Glutamine $\left[G \ln ^{4}\right]^{a}$ & & & & & $\mathrm{C} 47$ & $36.0, \mathrm{CH}_{2}$ a: & 1.26, obs. & & \\
\hline C18 & $171.2, \mathrm{C}$ & & & & & b: & 1.06, obs. & & \\
\hline C19 & $50.1, \mathrm{CH}$ & 4.40, obs. & 20 & & $\mathrm{C} 48$ & $33.8, \mathrm{CH}$ & 1.28, obs. & 51 & \\
\hline \multirow[t]{2}{*}{$\mathrm{C} 20$} & 26.5, $\mathrm{CH}_{2}$ a: & 1.89, obs. & 19,21 & 21,22 & $\mathrm{C} 49$ & 28.9, $\mathrm{CH}_{2}$ a: & 1.30, obs. & 50 & $47,48,50,51$ \\
\hline & $\mathrm{b}$ : & 1.78, obs. & 19,21 & 21,22 & & $\mathrm{~b}$ : & 1.10, obs. & 50 & $47,48,50,51$ \\
\hline $\mathrm{C} 21$ & $30.7, \mathrm{CH}_{2}$ & $2.12, \mathrm{~m}$ & 20 & 22 & C50 & $11.2, \mathrm{CH}_{3}$ & 0.83, obs. & 49 & \\
\hline $\mathrm{C} 22$ & $174.2, \mathrm{C}$ & & & & C51 & $19.1, \mathrm{CH}_{3}$ & 0.82, obs. & 48 & \\
\hline $\mathrm{NH}-19$ & & 7.15, obs. & 19 & & $\mathrm{NH}-37$ & & 7.14, obs. & 37 & \\
\hline $\mathrm{NH}_{2}-22$ & & $7.23,6.83$ & & 22 & & & & & \\
\hline \multicolumn{10}{|l|}{ Proline $\left[\right.$ Pro $\left.{ }^{5}\right]$} \\
\hline $\mathrm{C} 23$ & $172.5, \mathrm{C}$ & & & & & & & & \\
\hline $\mathrm{C} 24$ & $60.0, \mathrm{CH}$ & $4.32, \mathrm{t}(7.2)$ & 25 & $23,25,26$ & & & & & \\
\hline \multirow[t]{2}{*}{$\mathrm{C} 25$} & 29.1, $\mathrm{CH}_{2}$ a: & 2.11, obs. & 24 & & & & & & \\
\hline & $\mathrm{b}:$ & 1.77, obs. & 24 & & & & & & \\
\hline \multirow[t]{2}{*}{$\mathrm{C} 26$} & 24.7, $\mathrm{CH}_{2}$ a: & $1.98, \mathrm{~m}$ & 27 & $24,25,27$ & & & & & \\
\hline & $\mathrm{b}:$ & 1.86, obs. & 27 & $24,25,27$ & & & & & \\
\hline \multirow[t]{2}{*}{$\mathrm{C} 27$} & 47.2, $\mathrm{CH}_{2}$ a: & $3.81, \mathrm{bm}$ & 26 & 25,26 & & & & & \\
\hline & $\mathrm{b}:$ & 3.62 , obs. & 26 & 25,26 & & & & & \\
\hline
\end{tabular}

${ }^{a}$ Chemical shifts of $\mathrm{NH}_{2}$ groups for asparagine and glutamine residues were assigned arbitrarily unless an HMBC correlation is noted. ${ }^{b}$ Chemical shifts of carbons C-39 through C-46 were arbitrarily assigned and are interchangeable. 
Table S9. Mycosubtilin iso- $\mathrm{C}_{17}$ (9) NMR data.

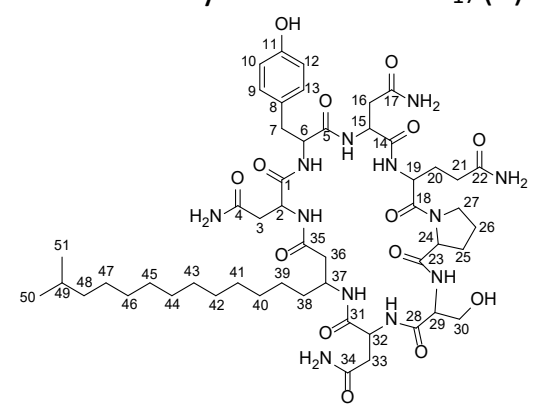

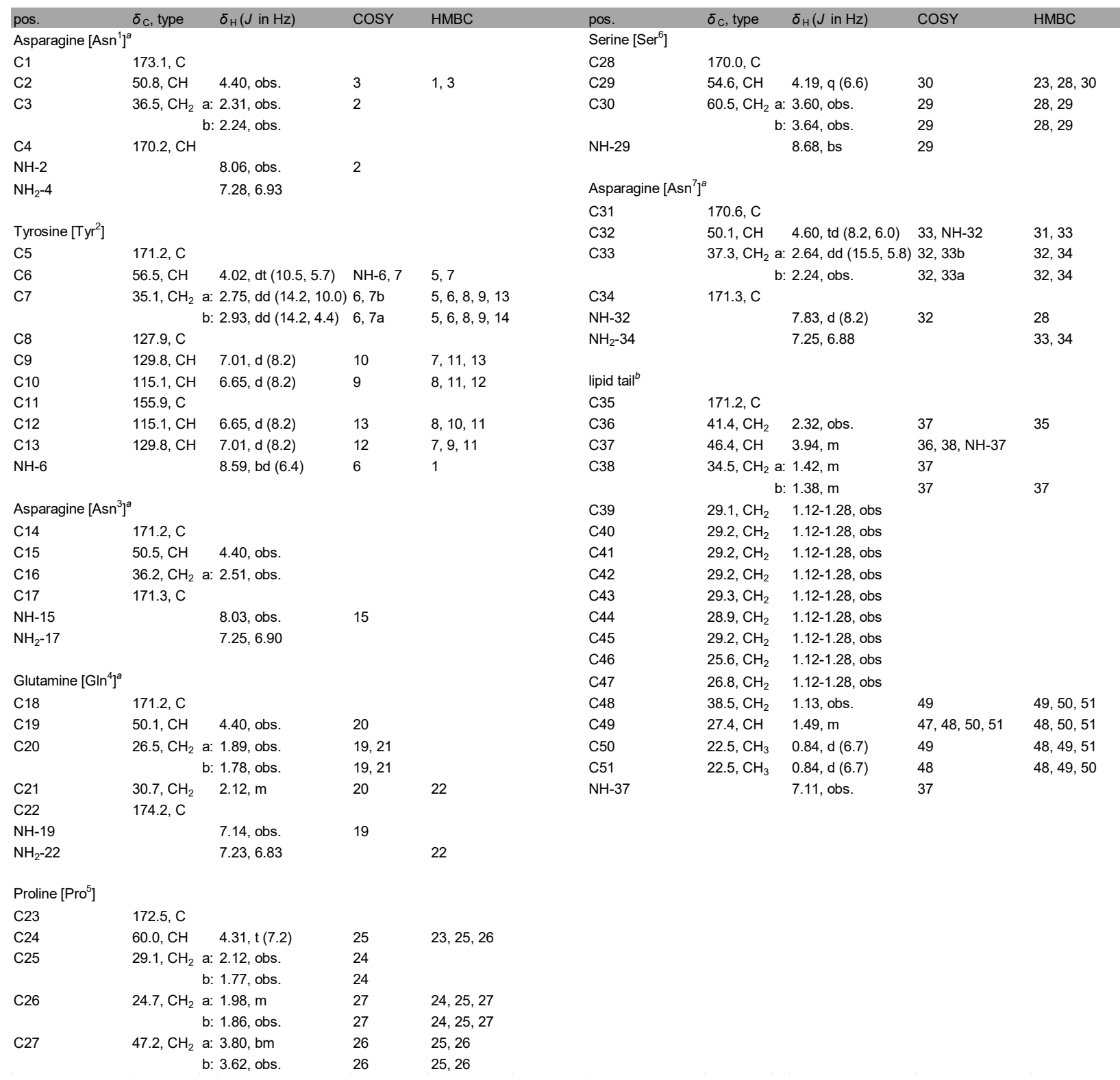

${ }^{a}$ Chemical shifts of $\mathrm{NH}_{2}$ groups for asparagine and glutamine residues were assigned arbitrarily unless an HMBC correlation is noted. ${ }^{b}$ Chemical shifts of carbons C-39 through C-47 were arbitrarily assigned and are interchangeable. 
Table S10. Fusaricidin A (10) NMR data.

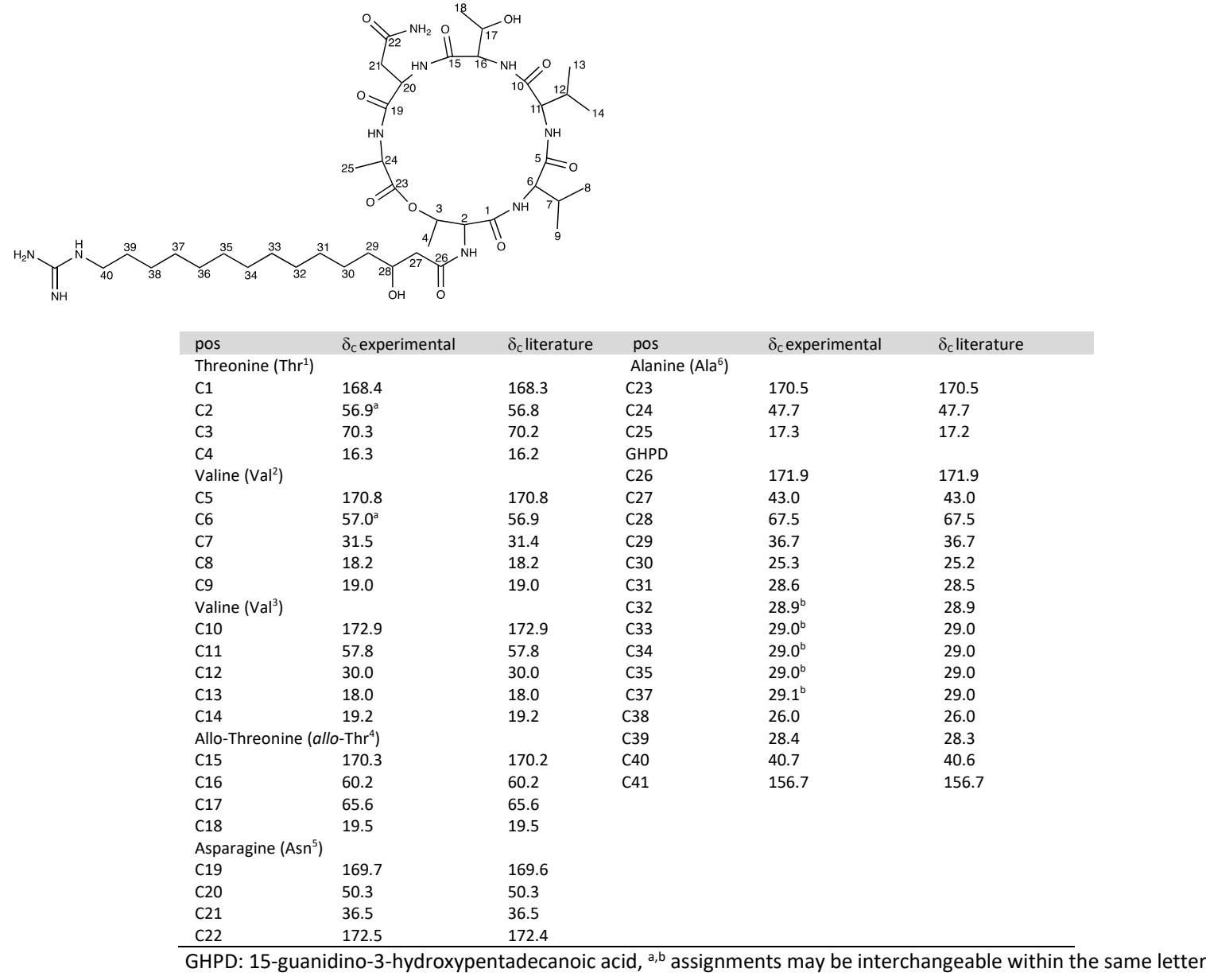




\section{NMR Spectra}

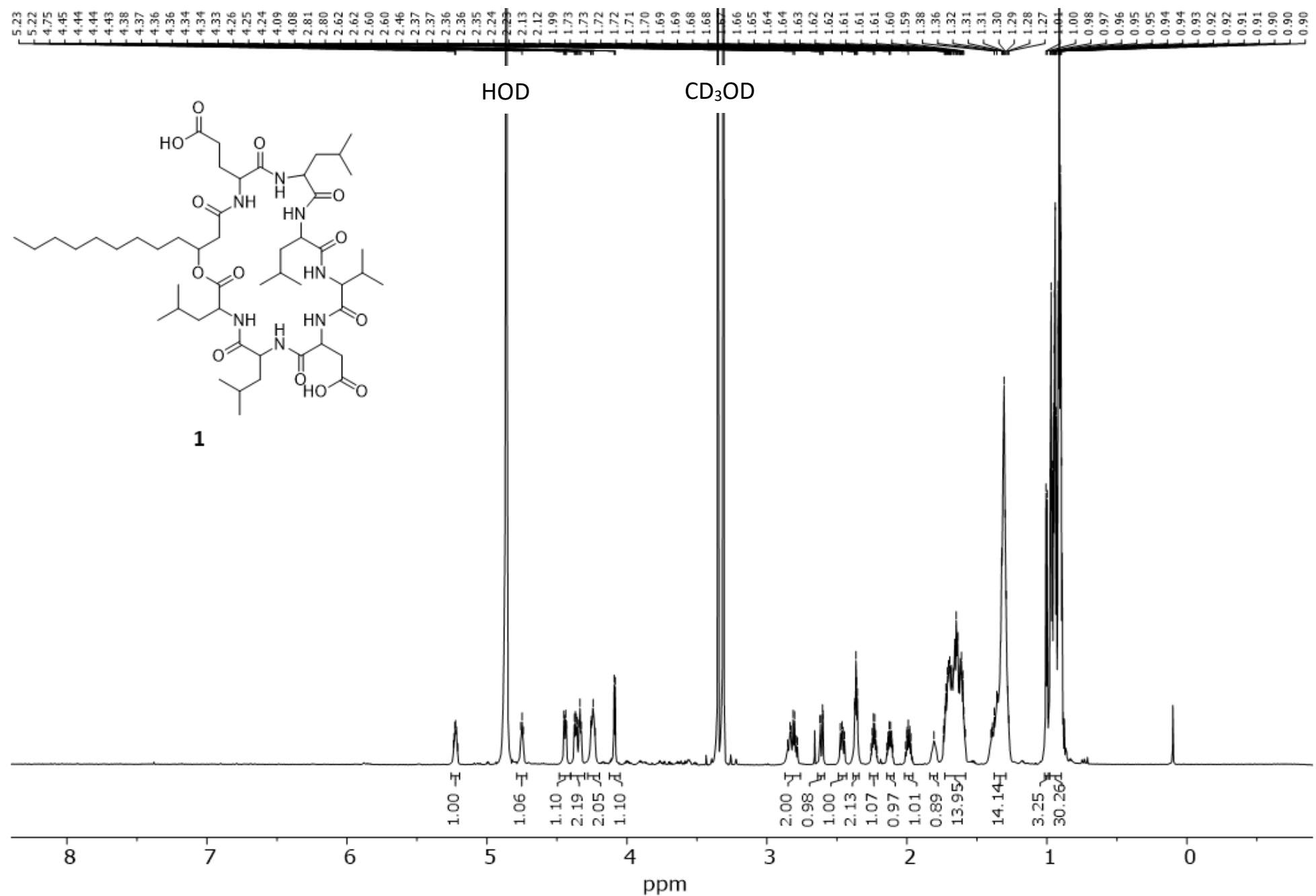

Figure S30. ${ }^{1} \mathrm{H}-\mathrm{NMR}$ spectrum of 1 in MeOD- $\mathrm{d}_{4}\left({ }^{1} \mathrm{H}: 600 \mathrm{MHz}\right)$. 
ஸ

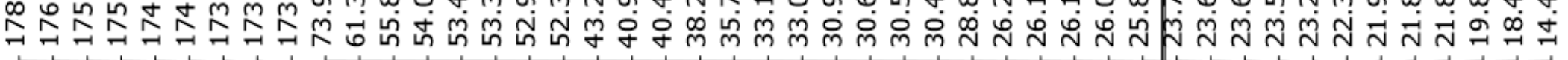

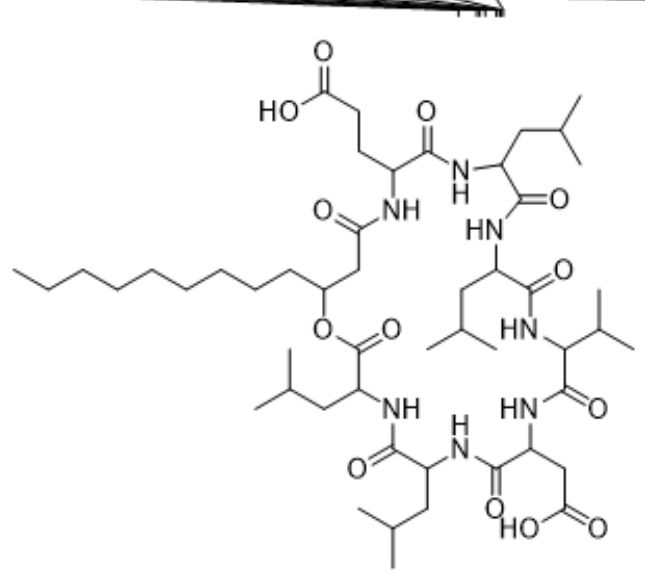

1
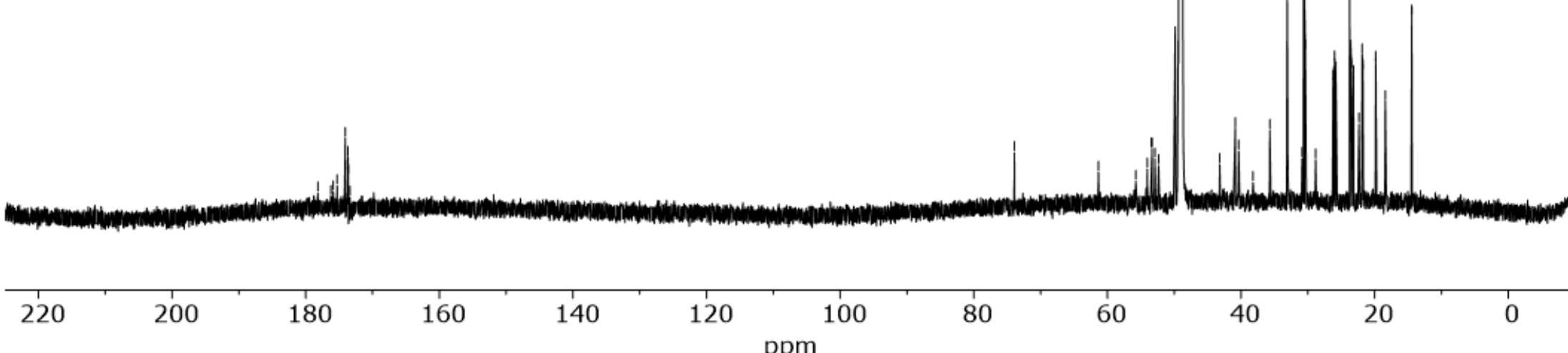

Figure S31. ${ }^{13} \mathrm{C}-\mathrm{NMR}$ spectrum of $\mathbf{1}$ in MeOD-d $\left({ }^{13} \mathrm{C}: 150 \mathrm{MHz}\right)$. 


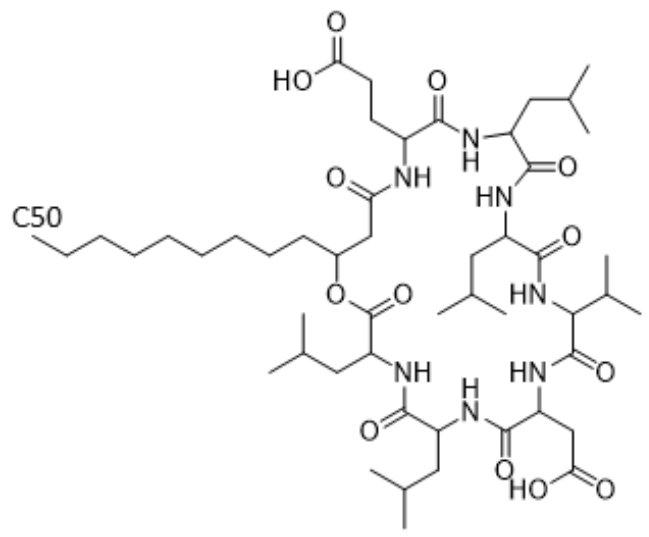

1

C50

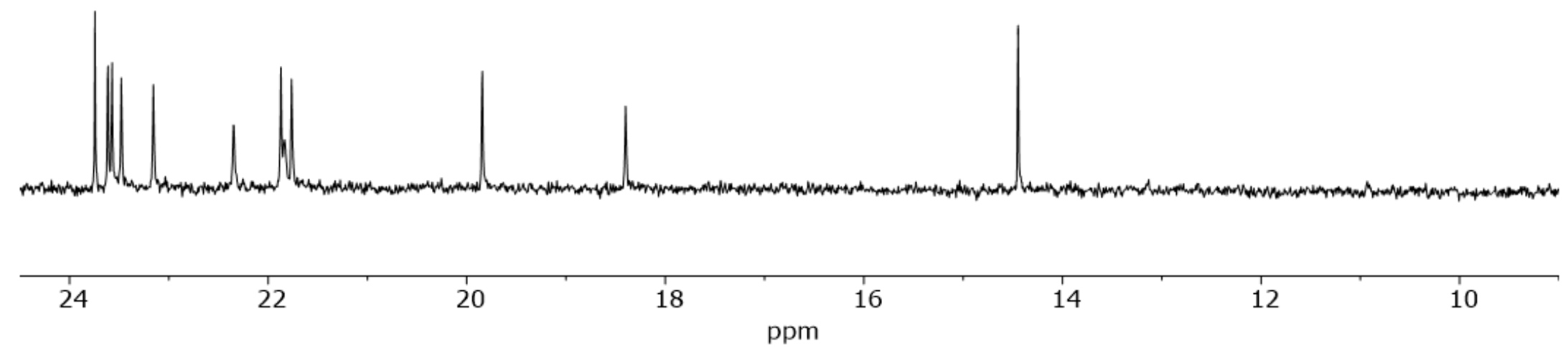

Figure S32. ${ }^{13} \mathrm{C}-\mathrm{NMR}$ spectrum of 1 in MeOD- $\mathrm{d}_{4}\left({ }^{13} \mathrm{C}: 150 \mathrm{MHz}\right)$, illustrating important methyl peaks used to determine chain branching. 


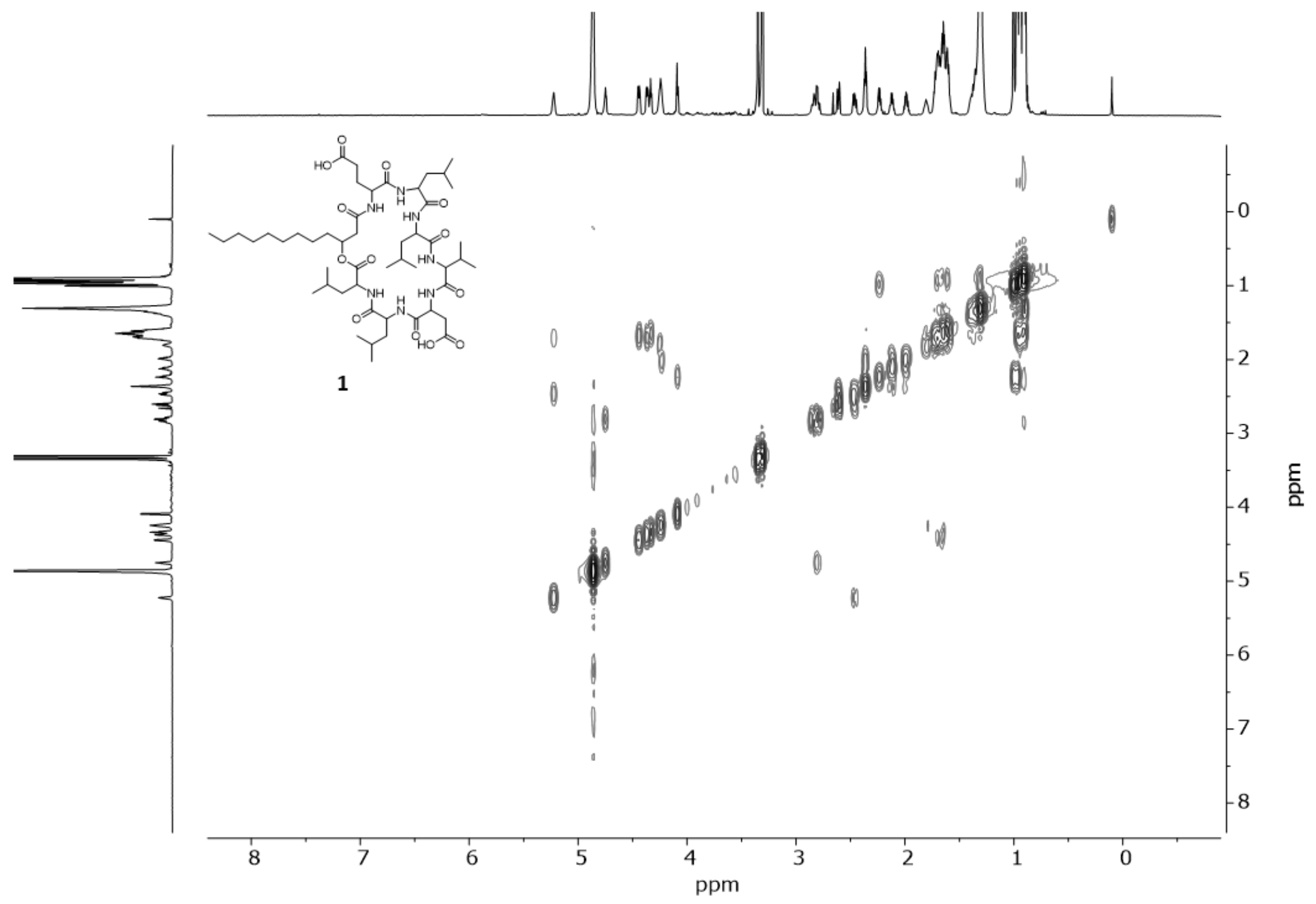

Figure S33. $\operatorname{COSY}\left({ }^{1} \mathrm{H}-{ }^{-1} \mathrm{H}\right)$ spectrum of 1 in MeOD- $\mathrm{d}_{4}(600 \mathrm{MHz})$. 


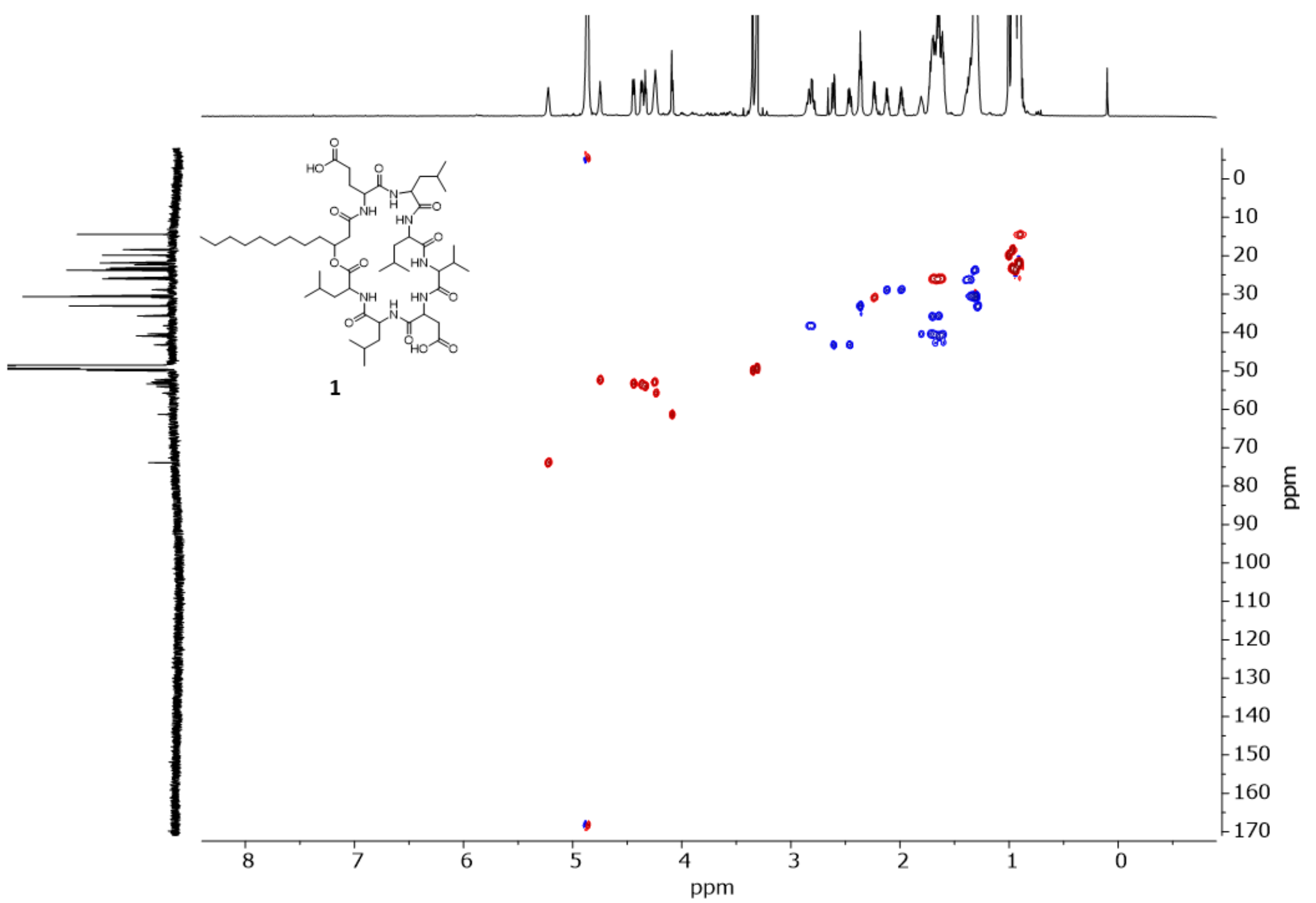

Figure S34. $\mathrm{HSQC}\left({ }^{1} \mathrm{H}-{ }^{13} \mathrm{C}\right)$ spectrum of 1 in MeOD- $\mathrm{d}_{4}$. Red contours represent $\mathrm{CH}$ and $\mathrm{CH}_{3}$ groups, blue contours represent $\mathrm{CH}_{2}$ groups. 


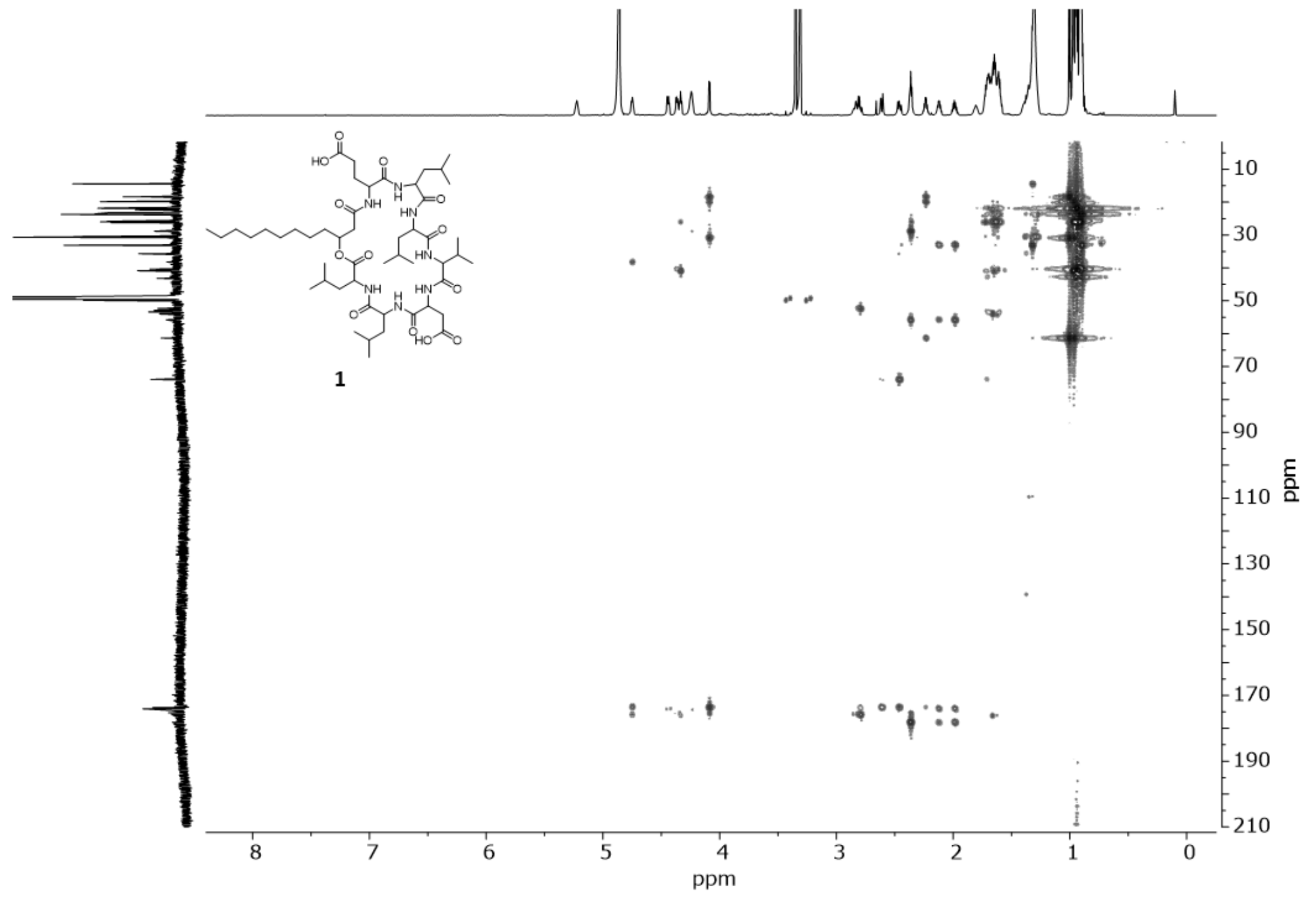

Figure S35. $\mathrm{HMBC}\left({ }^{1} \mathrm{H}-{ }^{13} \mathrm{C}\right)$ spectrum of $\mathbf{1}$ in $\mathrm{MeOD}-\mathrm{d}_{4}$. 


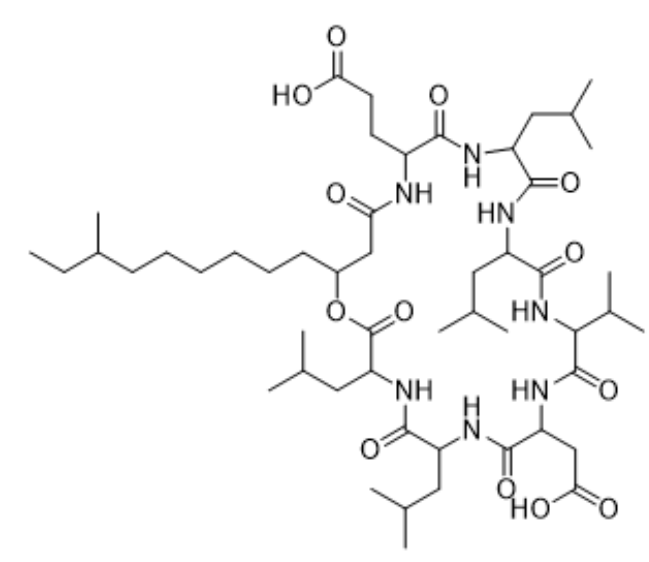

2

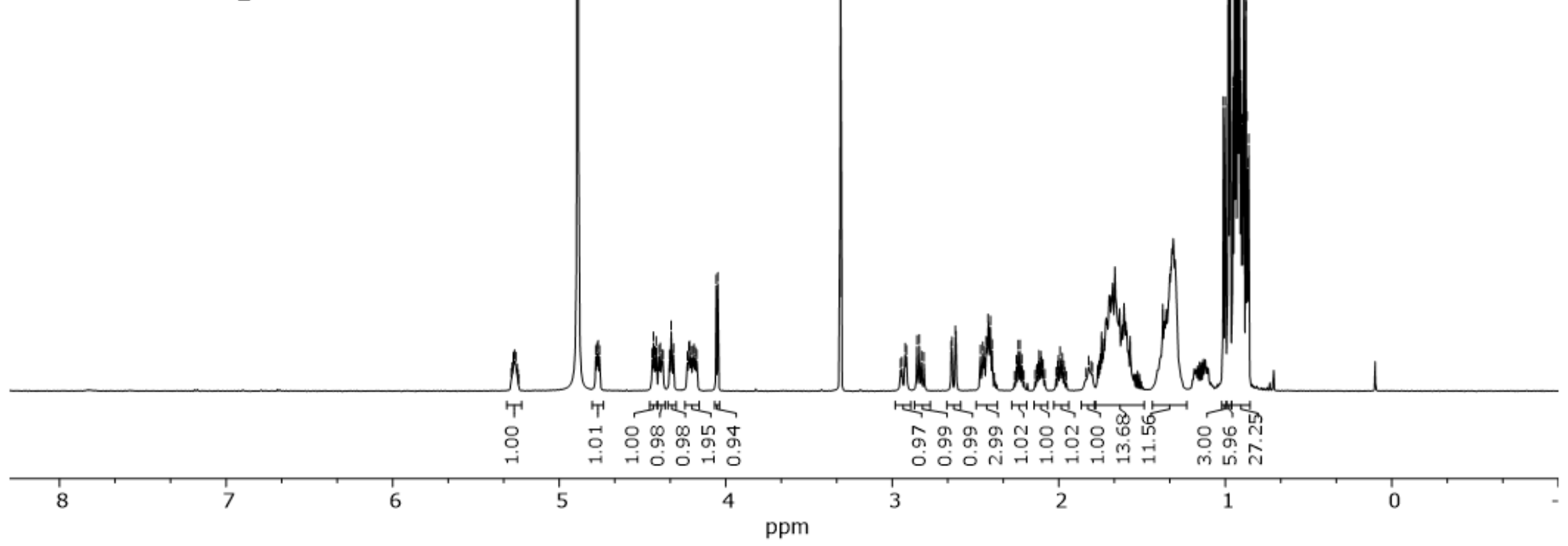

Figure S36. ${ }^{1} \mathrm{H}-\mathrm{NMR}$ spectrum of 2 in MeOD- $\mathrm{d}_{4}\left({ }^{1} \mathrm{H}: 600 \mathrm{MHz}\right)$. 


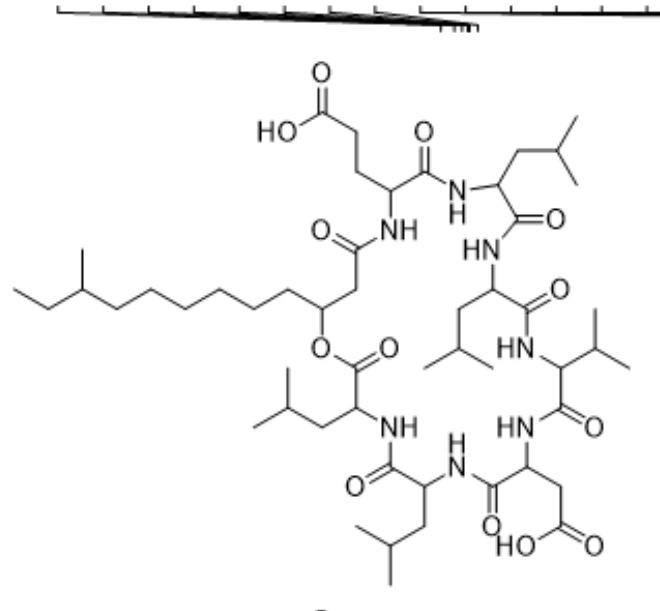

2
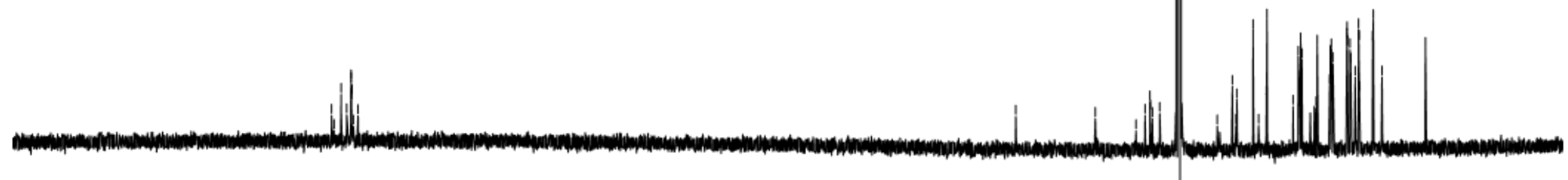

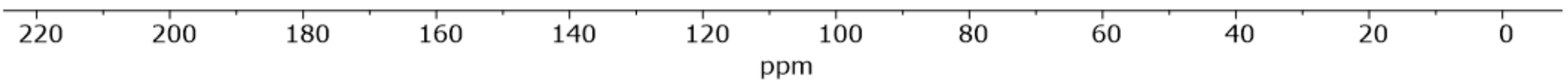

Figure S37. ${ }^{13} \mathrm{C}-\mathrm{NMR}$ spectrum of $\mathbf{2}$ in MeOD- $\mathrm{d}_{4}\left({ }^{13} \mathrm{C}: 150 \mathrm{MHz}\right)$. 


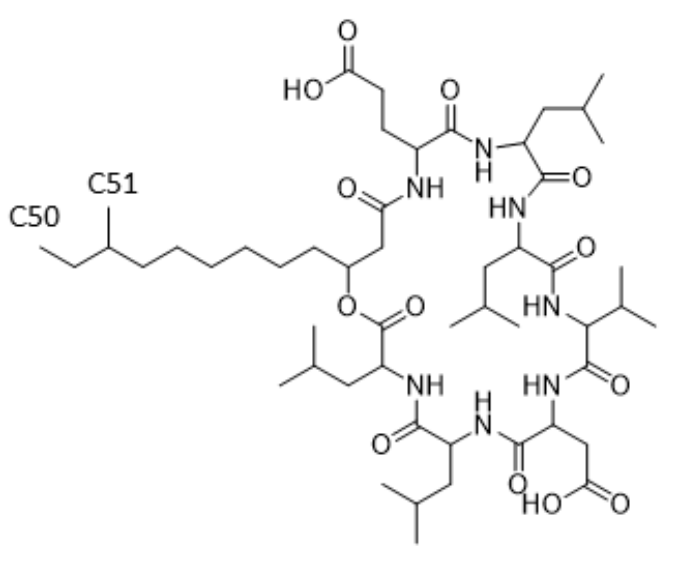

2

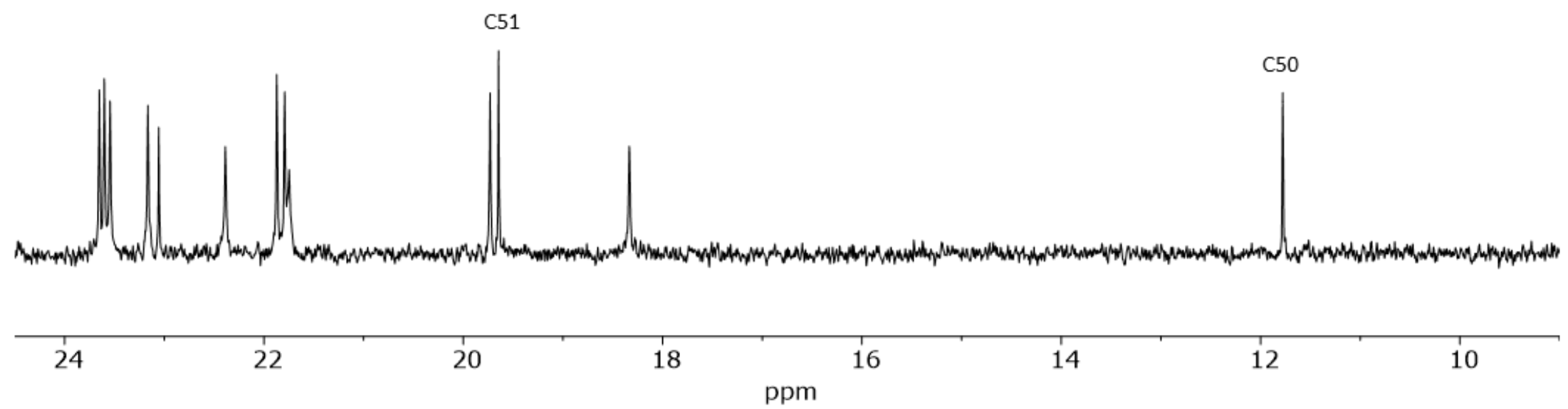

Figure S38. ${ }^{13} \mathrm{C}-\mathrm{NMR}$ spectrum of 2 in MeOD-d $\left({ }^{13} \mathrm{C}: 150 \mathrm{MHz}\right)$, illustrating important methyl peaks used to determine chain branching. 


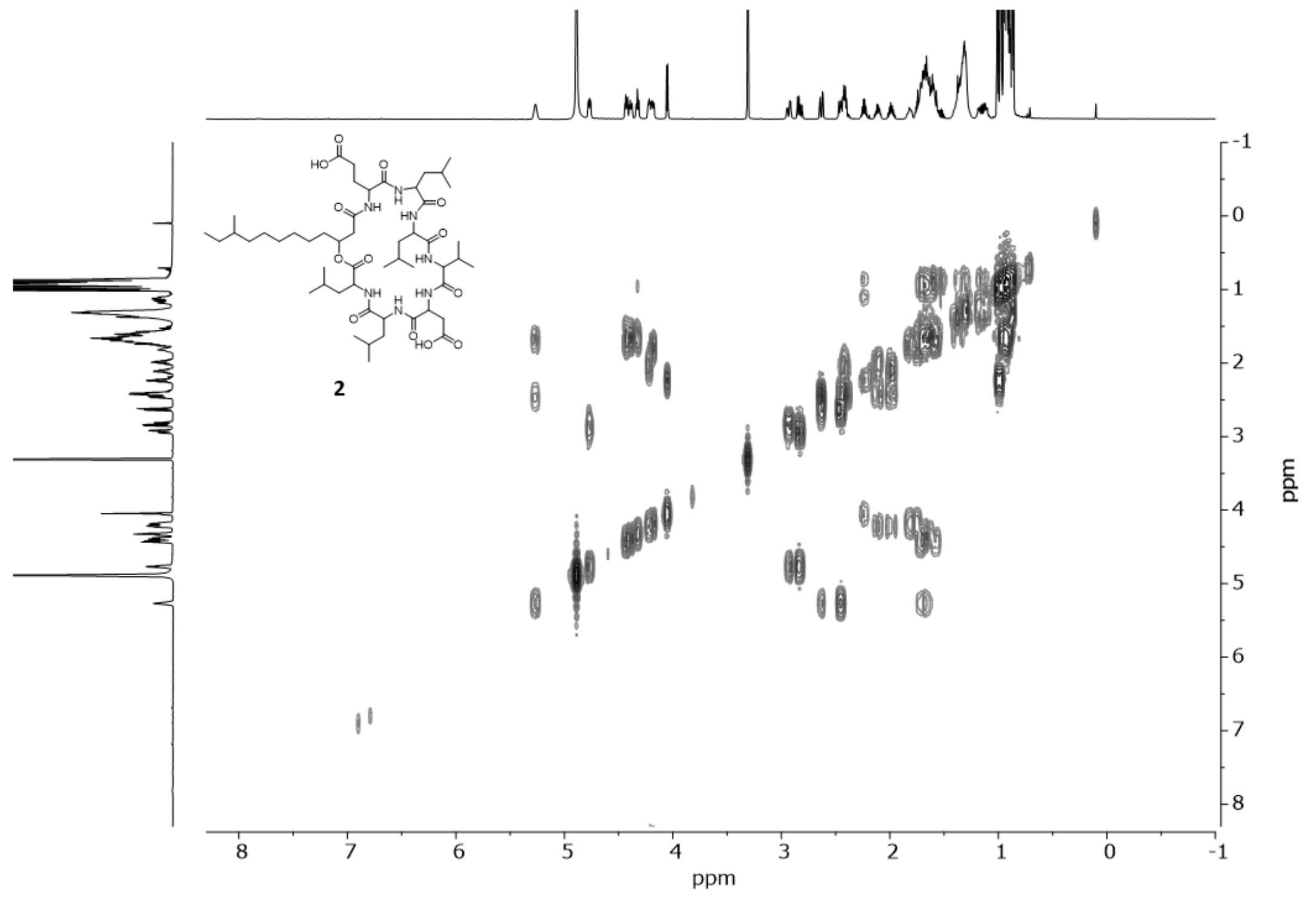

Figure S39. $\operatorname{COSY}\left({ }^{1} \mathrm{H}^{-1} \mathrm{H}\right)$ spectrum of 2 in MeOD- $\mathrm{d}_{4}(600 \mathrm{MHz})$. 


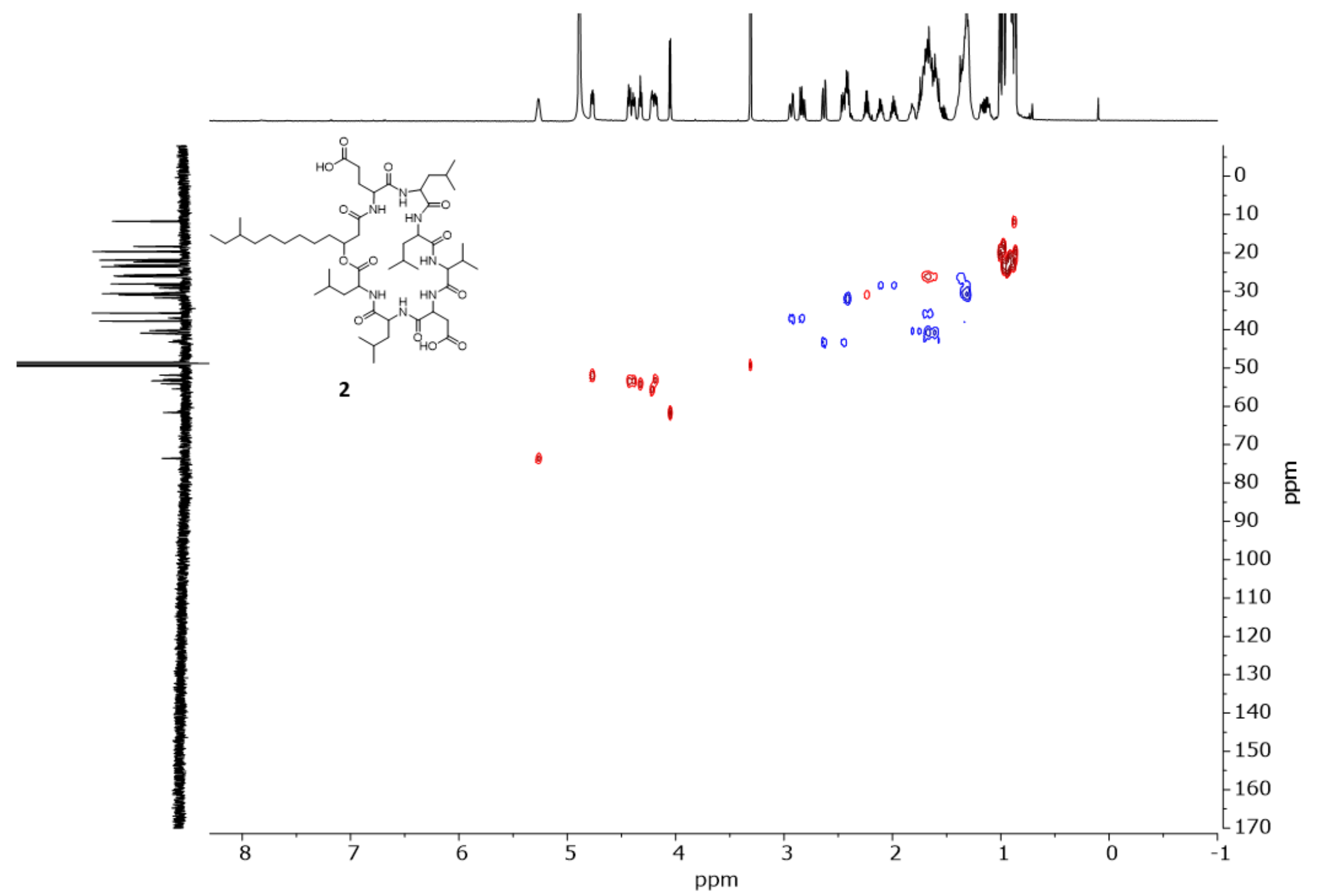

Figure S40. HSQC $\left({ }^{1} \mathrm{H}^{-13} \mathrm{C}\right)$ spectrum of 2 in MeOD- $\mathrm{d}_{4}$. Red contours represent $\mathrm{CH}$ and $\mathrm{CH}_{3}$ groups, blue contours represent $\mathrm{CH}_{2}$ groups. 


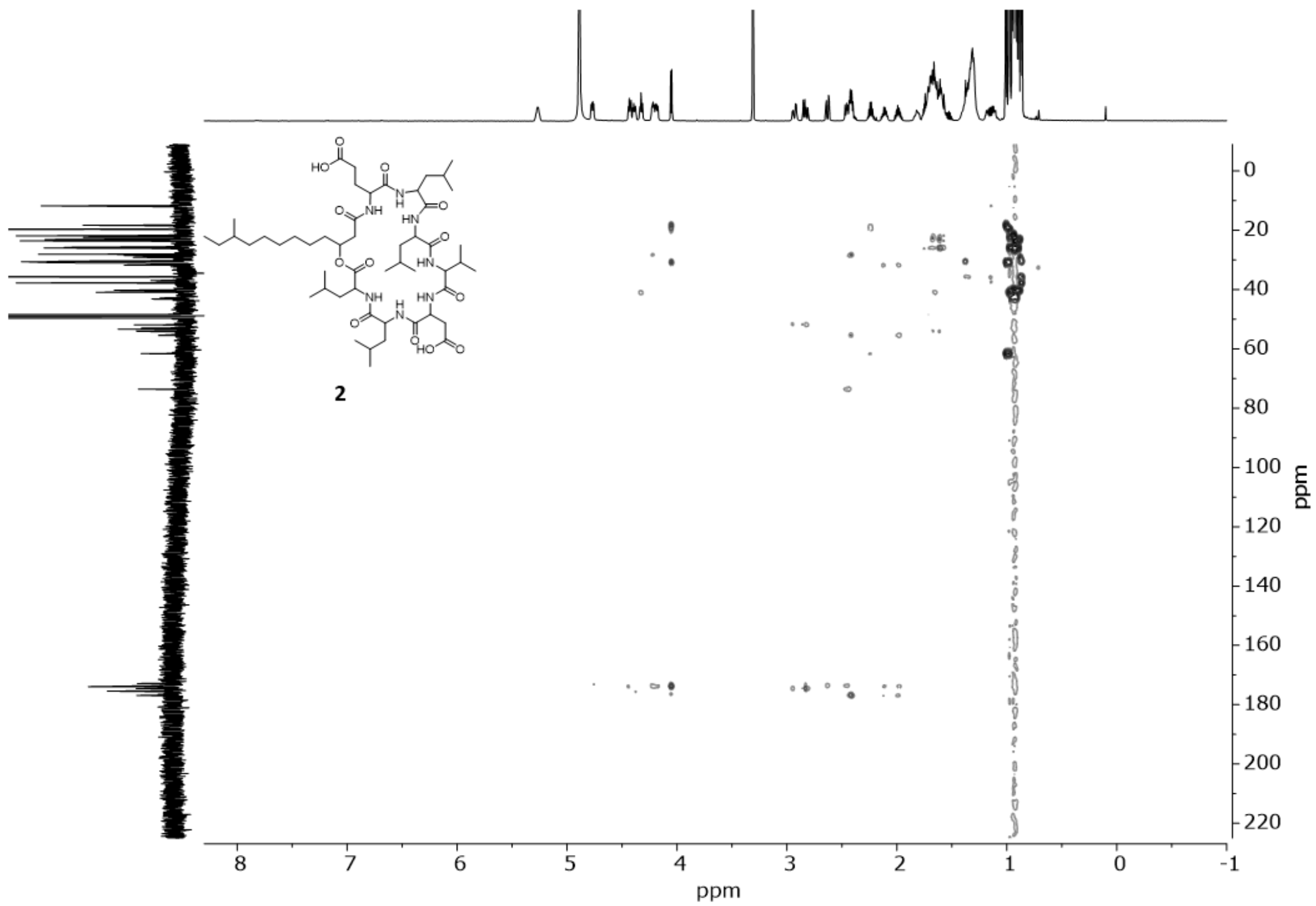

Figure S41. $\mathrm{HMBC}\left({ }^{1} \mathrm{H}_{-}{ }^{13} \mathrm{C}\right)$ spectrum of $\mathbf{2}$ in MeOD- $\mathrm{d}_{4}$.

S53 


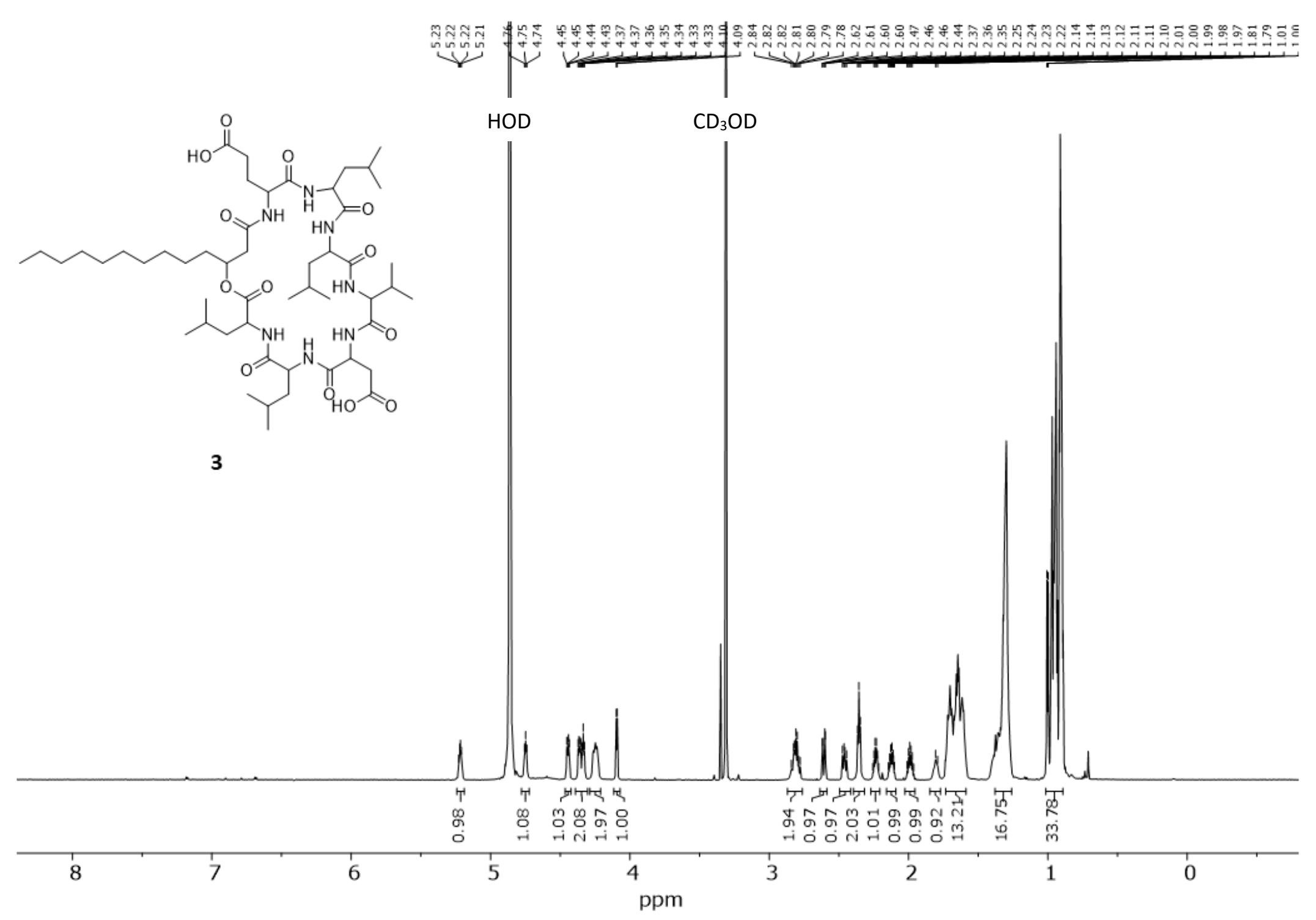

Figure S42. ${ }^{1} \mathrm{H}-\mathrm{NMR}$ spectrum of $\mathbf{3}$ in MeOD-d $\mathrm{d}_{4}\left({ }^{1} \mathrm{H}: 800 \mathrm{MHz}\right)$. 


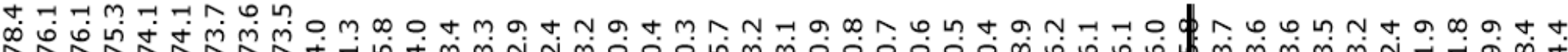

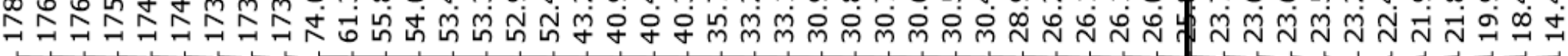

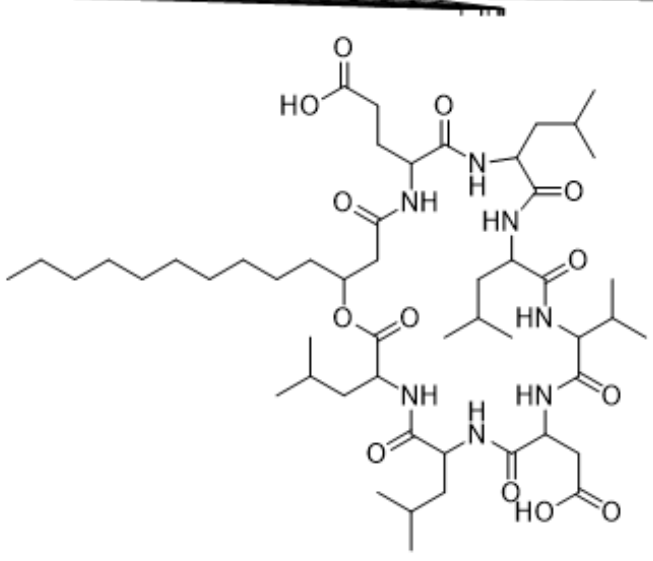

3

\section{$\mathrm{CD}_{3} \mathrm{OD}$}
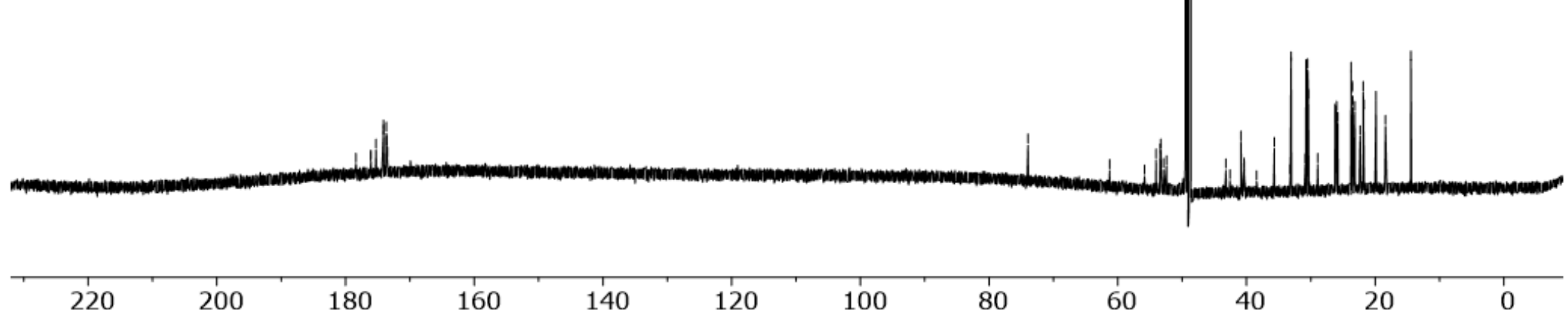

180

160

140

120

100

80

40

20

Figure S43. ${ }^{13} \mathrm{C}-\mathrm{NMR}$ spectrum of $\mathbf{3}$ in MeOD- $\mathrm{d}_{4}\left({ }^{13} \mathrm{C}: 200 \mathrm{MHz}\right)$. 


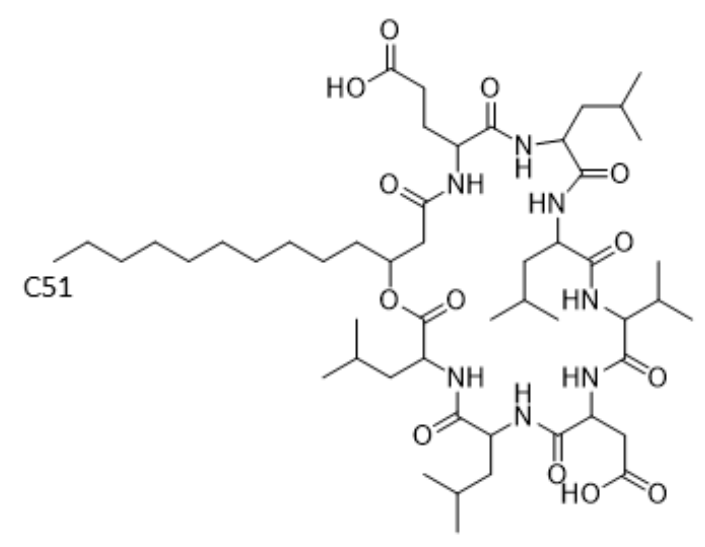

3

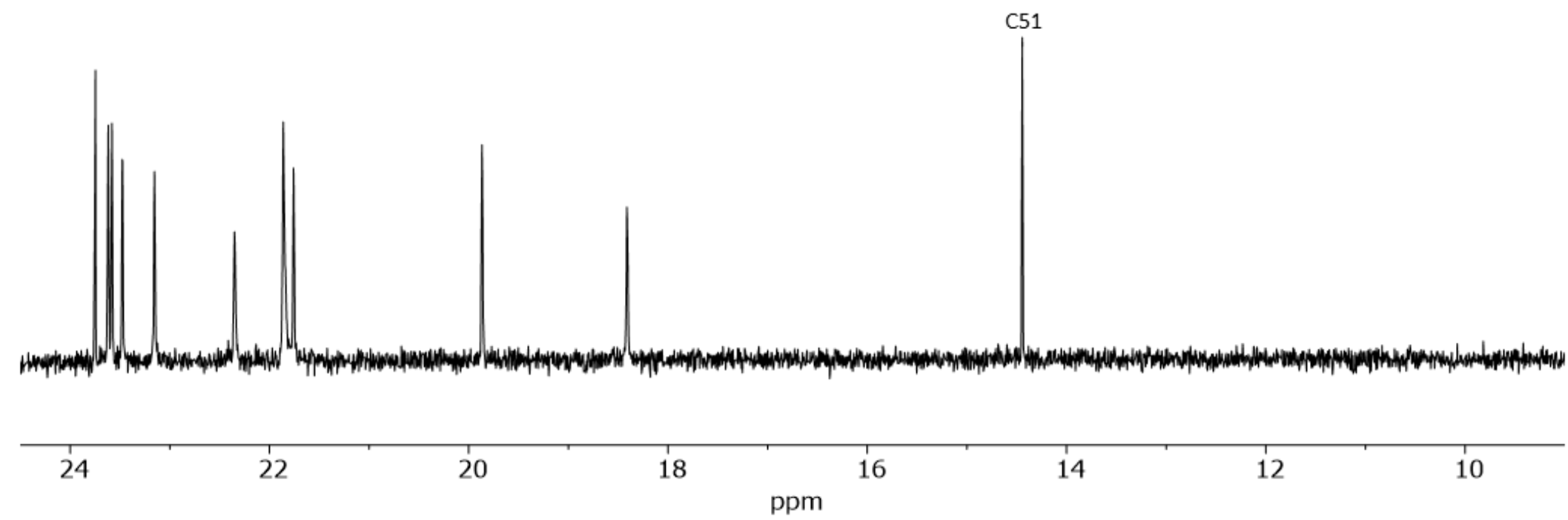

Figure S44. ${ }^{13} \mathrm{C}-\mathrm{NMR}$ spectrum of $\mathbf{3}$ in MeOD- $\mathrm{d}_{4}\left({ }^{13} \mathrm{C}: 200 \mathrm{MHz}\right)$, illustrating important methyl peaks used to determine chain branching. 


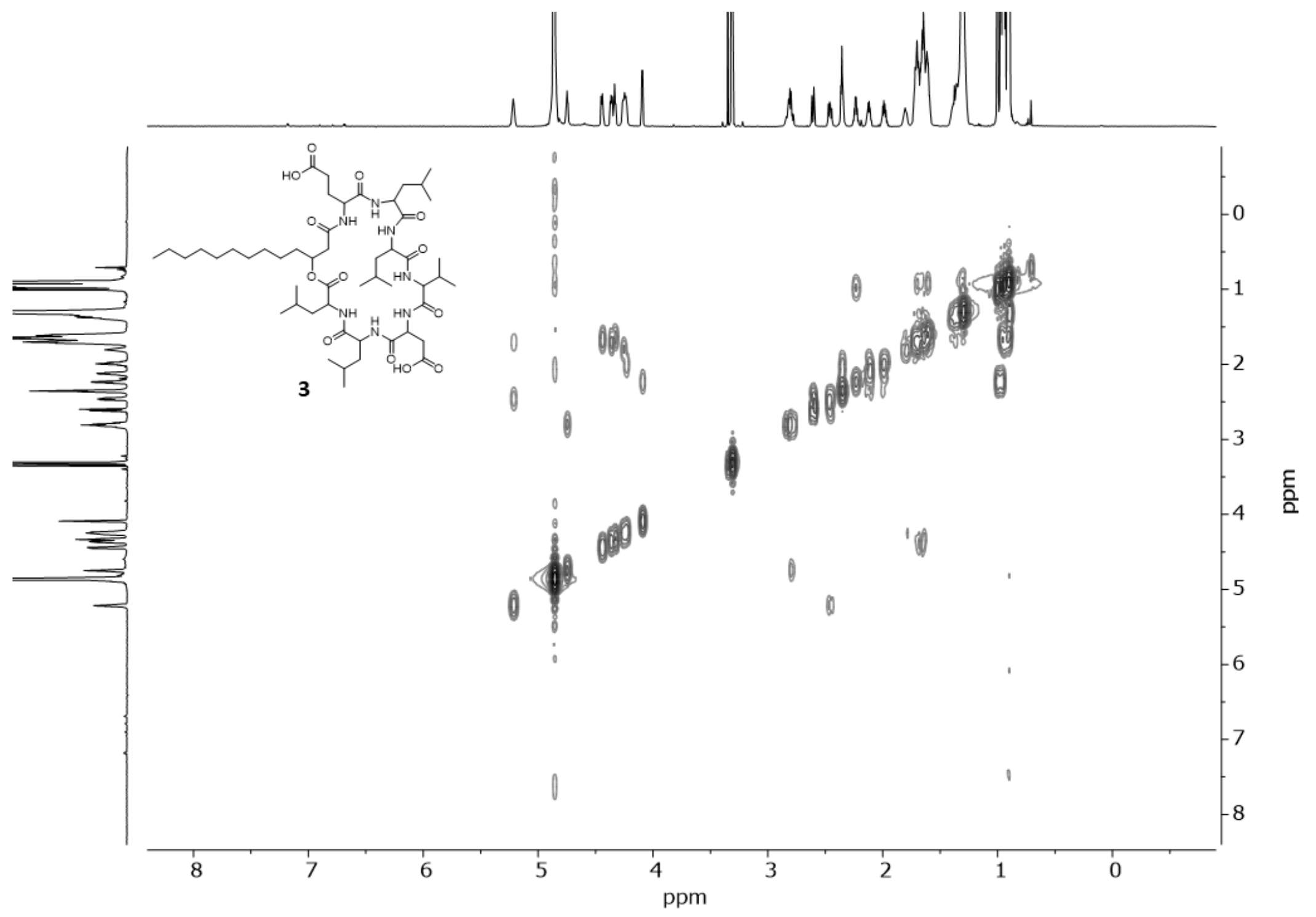

Figure S45. $\operatorname{COSY}\left({ }^{1} \mathrm{H}-{ }^{-1} \mathrm{H}\right)$ spectrum of $\mathbf{3}$ in MeOD- $\mathrm{d}_{4}(800 \mathrm{MHz})$. 


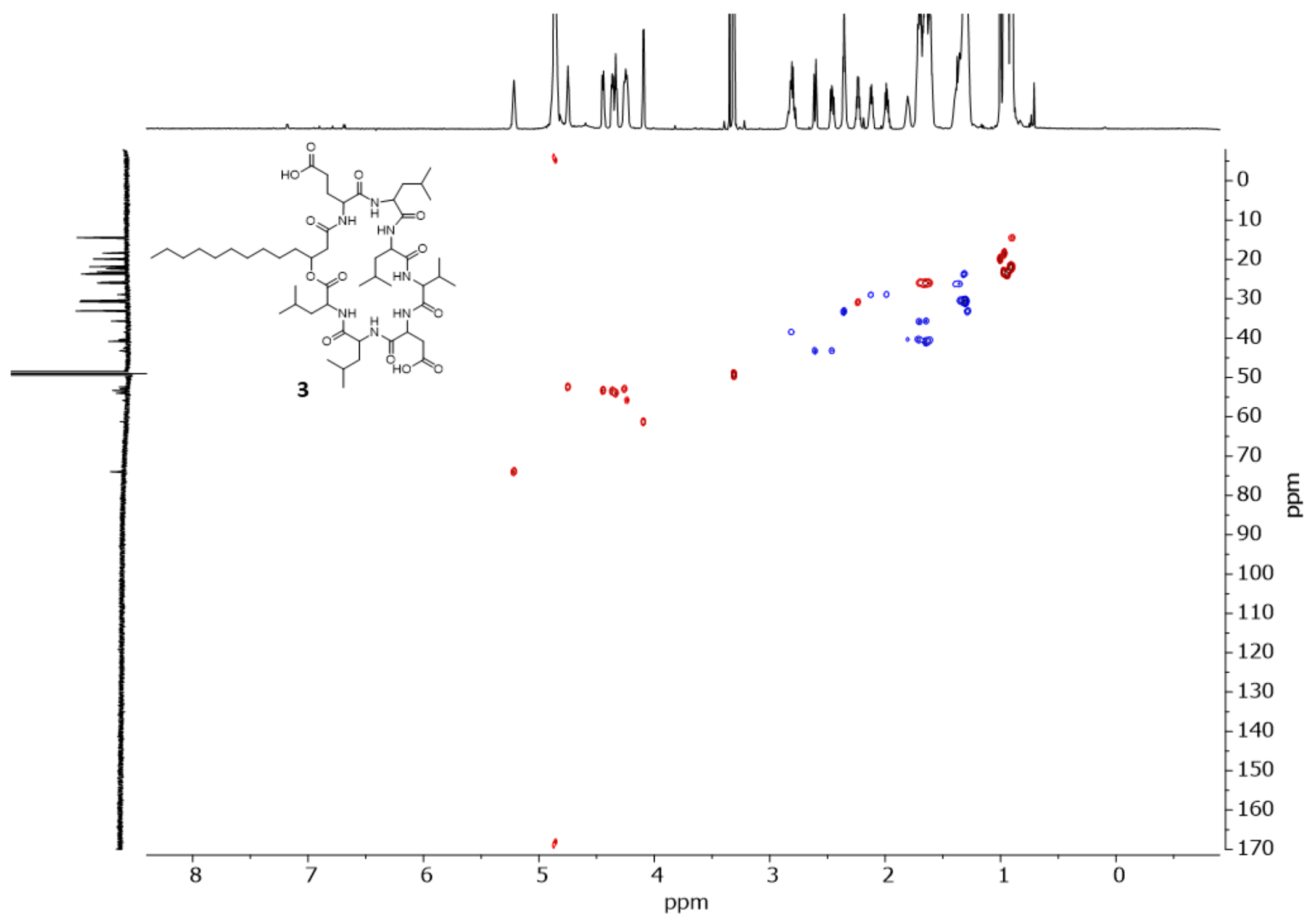

Figure S46. $\mathrm{HSQC}\left({ }^{1} \mathrm{H}_{-13}{ }^{13} \mathrm{C}\right)$ spectrum of 3 in MeOD- $\mathrm{d}_{4}$. Red contours represent $\mathrm{CH}$ and $\mathrm{CH}_{3}$ groups, blue contours represent $\mathrm{CH}_{2}$ groups. 


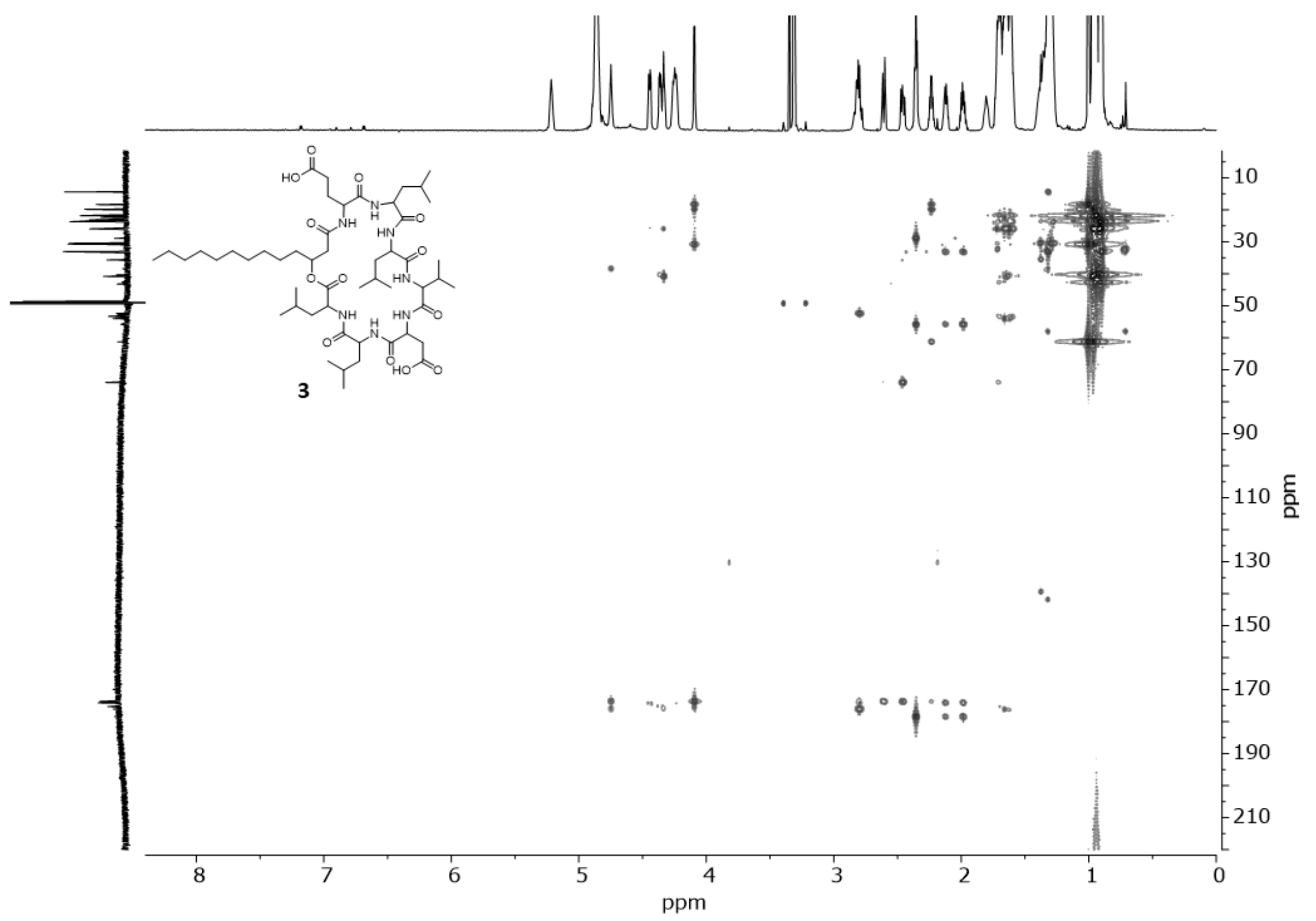

Figure S47. $\mathrm{HMBC}\left({ }^{1} \mathrm{H}_{-}{ }^{13} \mathrm{C}\right)$ spectrum of $\mathbf{3}$ in MeOD- $\mathrm{d}_{4}$. 


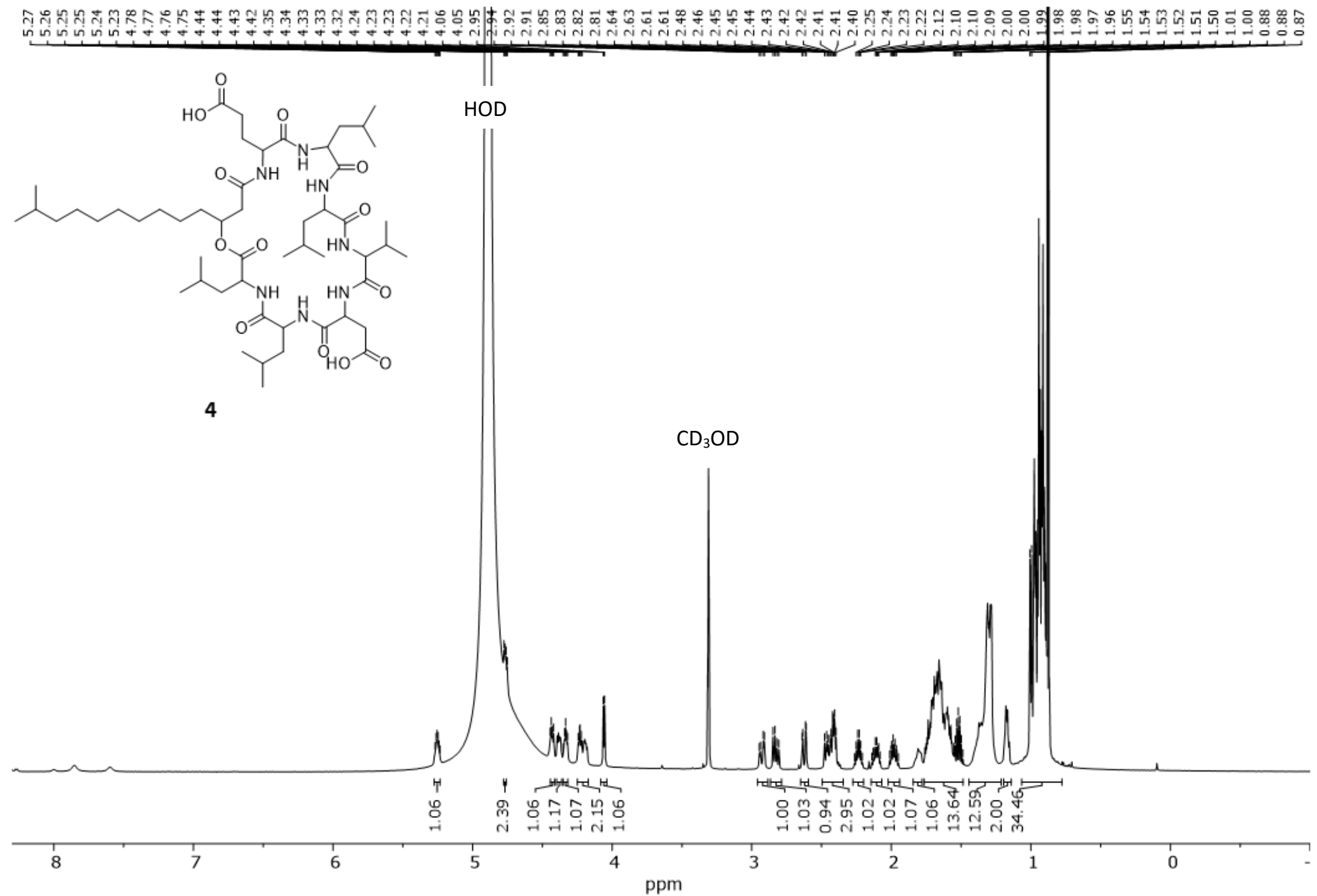

Figure S48. ${ }^{1} \mathrm{H}-\mathrm{NMR}$ spectrum of 4 in MeOD- $\mathrm{d}_{4}\left({ }^{1} \mathrm{H}: 600 \mathrm{MHz}\right)$. 


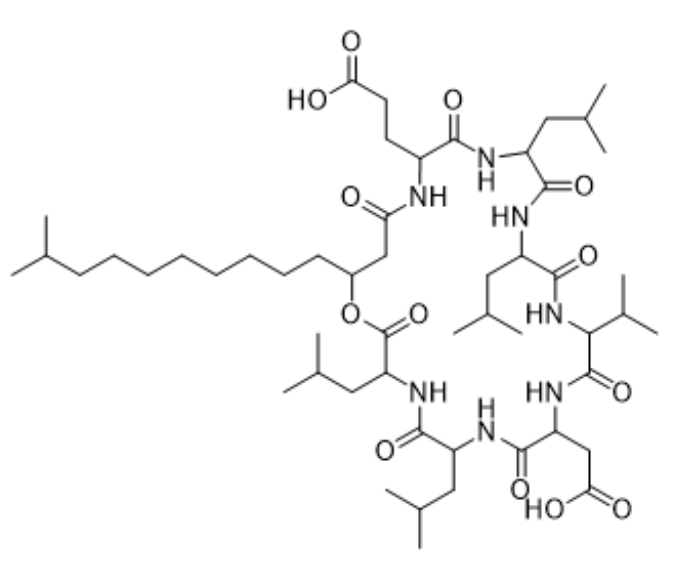

4

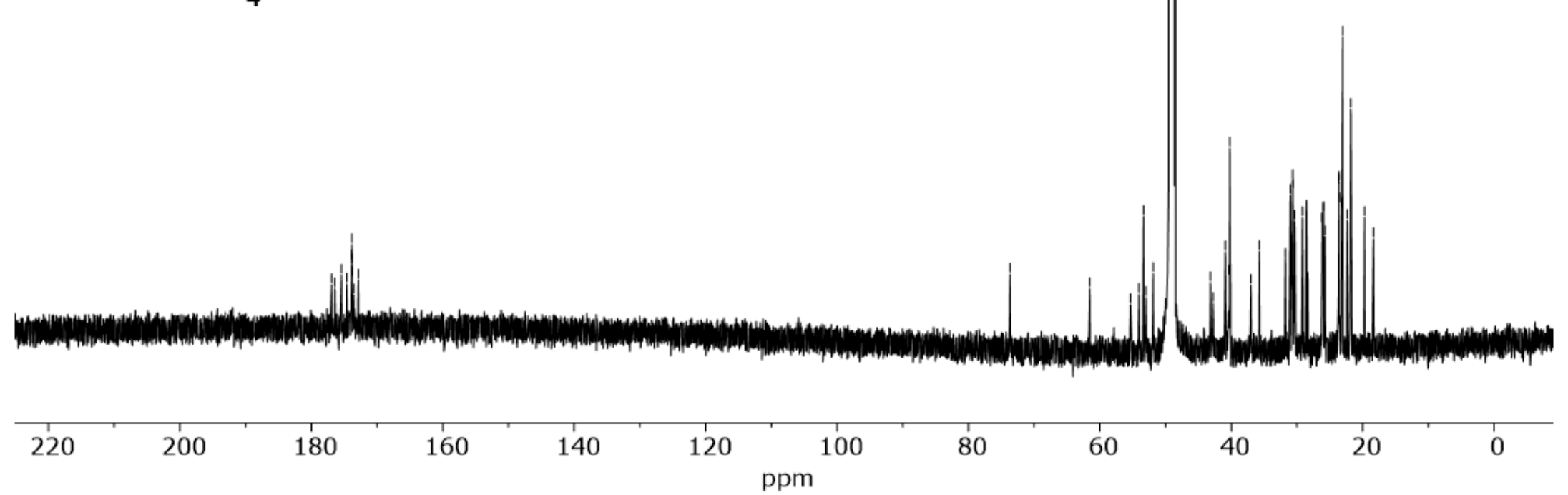

Figure S49. ${ }^{13} \mathrm{C}-\mathrm{NMR}$ spectrum of $\mathbf{4}$ in MeOD- $\mathrm{d}_{4}\left({ }^{13} \mathrm{C}\right.$ : $\left.150 \mathrm{MHz}\right)$. 


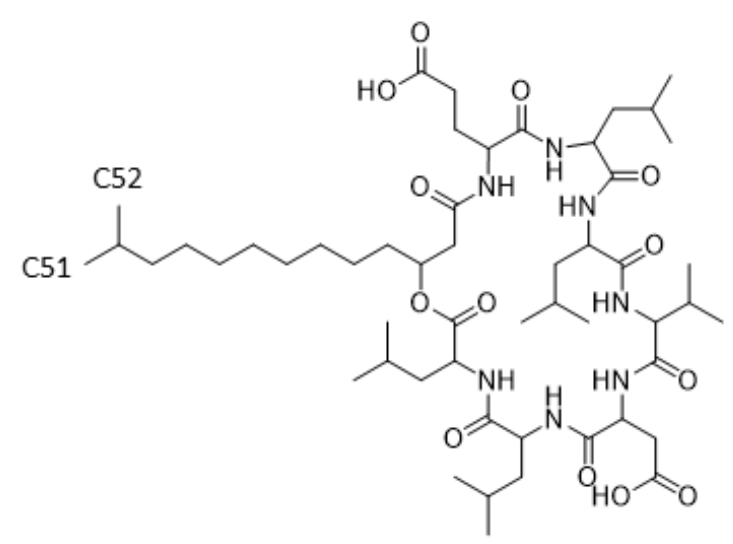

C51

C52

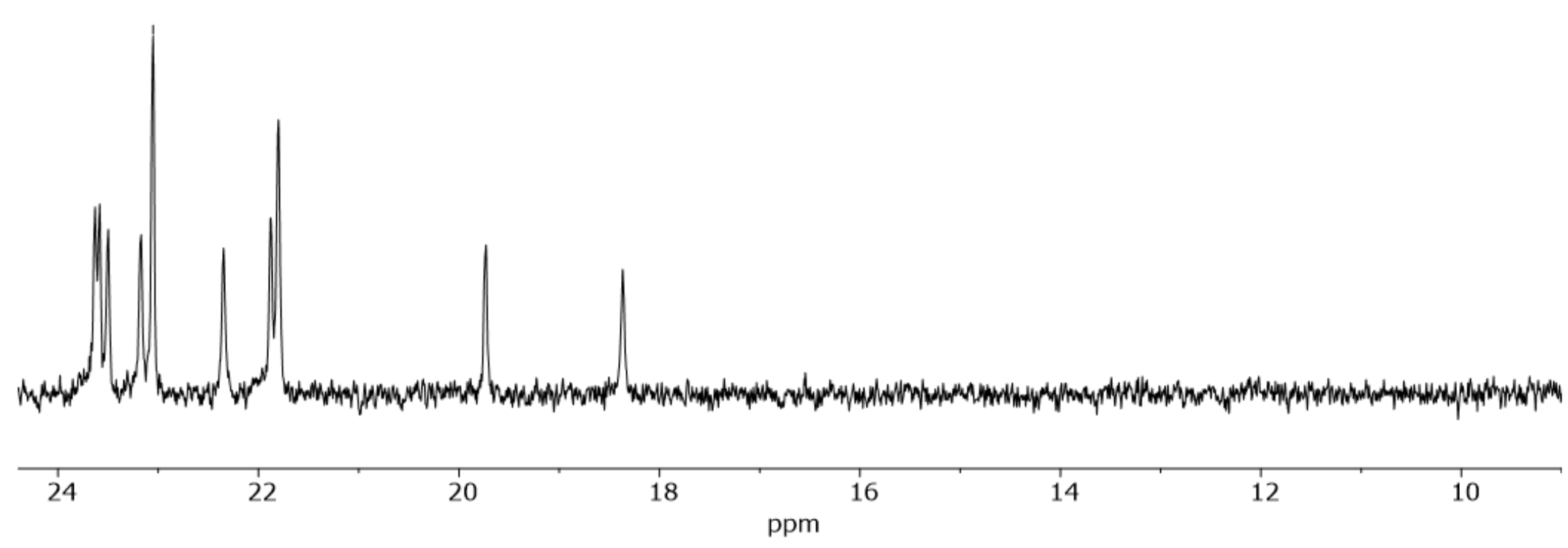

Figure S50. ${ }^{13} \mathrm{C}-\mathrm{NMR}$ spectrum of 4 in MeOD-d $\left({ }^{13} \mathrm{C}: 150 \mathrm{MHz}\right)$, illustrating important methyl peaks used to determine chain branching. 


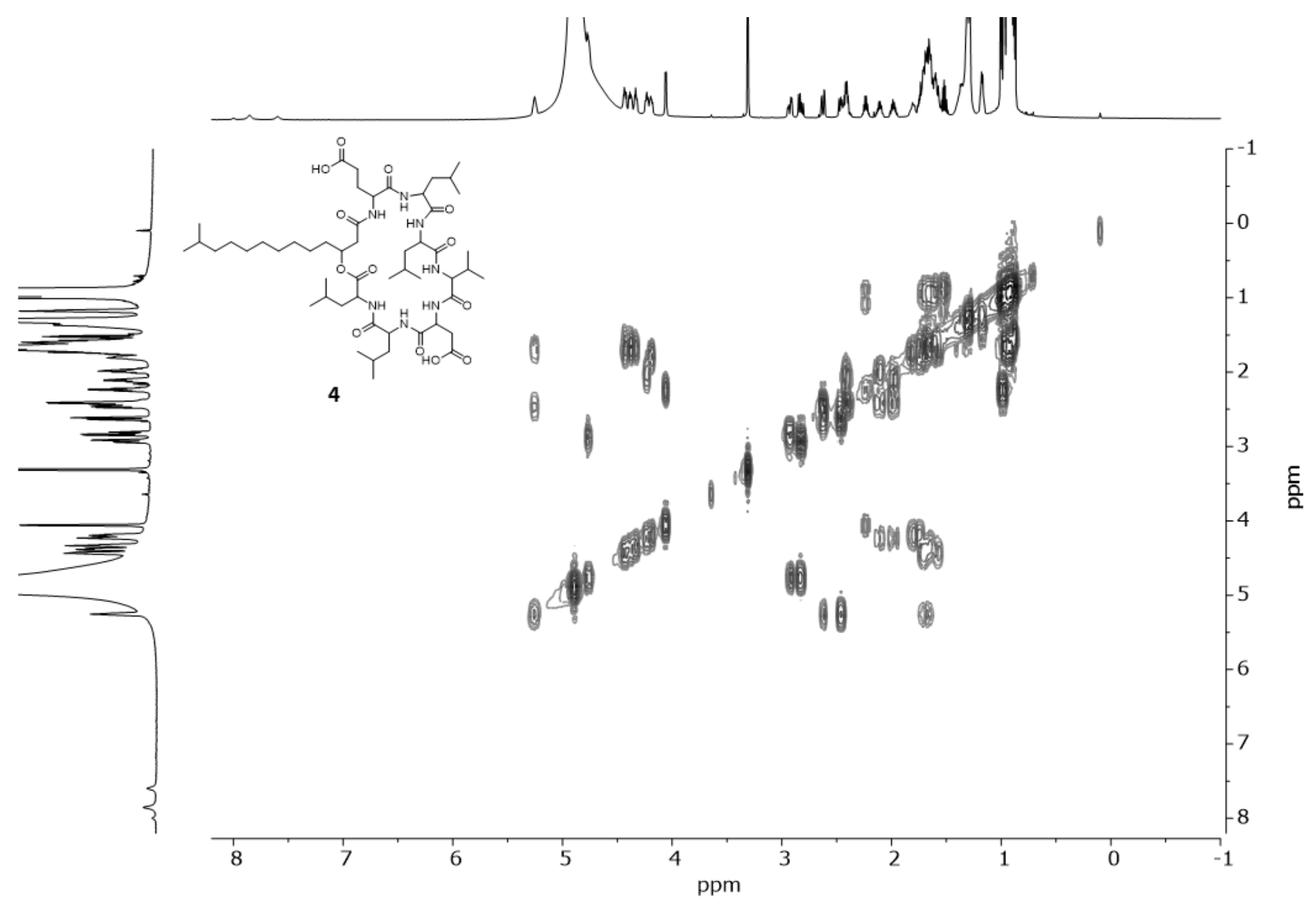

Figure S51. $\operatorname{COSY}\left({ }^{1} \mathrm{H}-{ }^{-1} \mathrm{H}\right)$ spectrum of $\mathbf{4}$ in MeOD- $\mathrm{d}_{4}(600 \mathrm{MHz})$. 


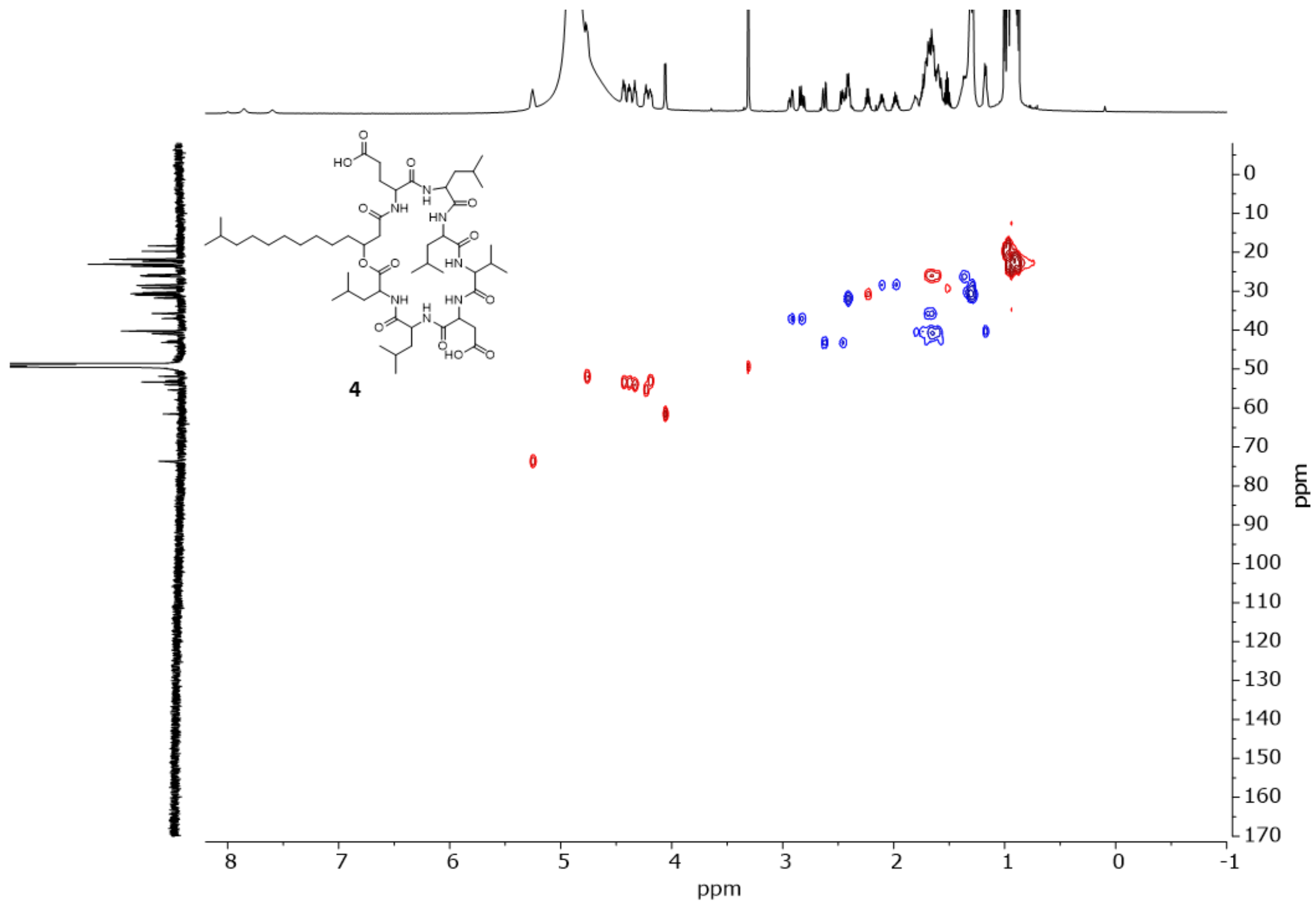

Figure S52. $\mathrm{HSQC}\left({ }^{1} \mathrm{H}_{-}{ }^{13} \mathrm{C}\right)$ spectrum of 4 in MeD- $\mathrm{d}_{4}$. Red contours represent $\mathrm{CH}$ and $\mathrm{CH}_{3}$ groups, blue contours represent $\mathrm{CH}_{2}$ groups.

S64 


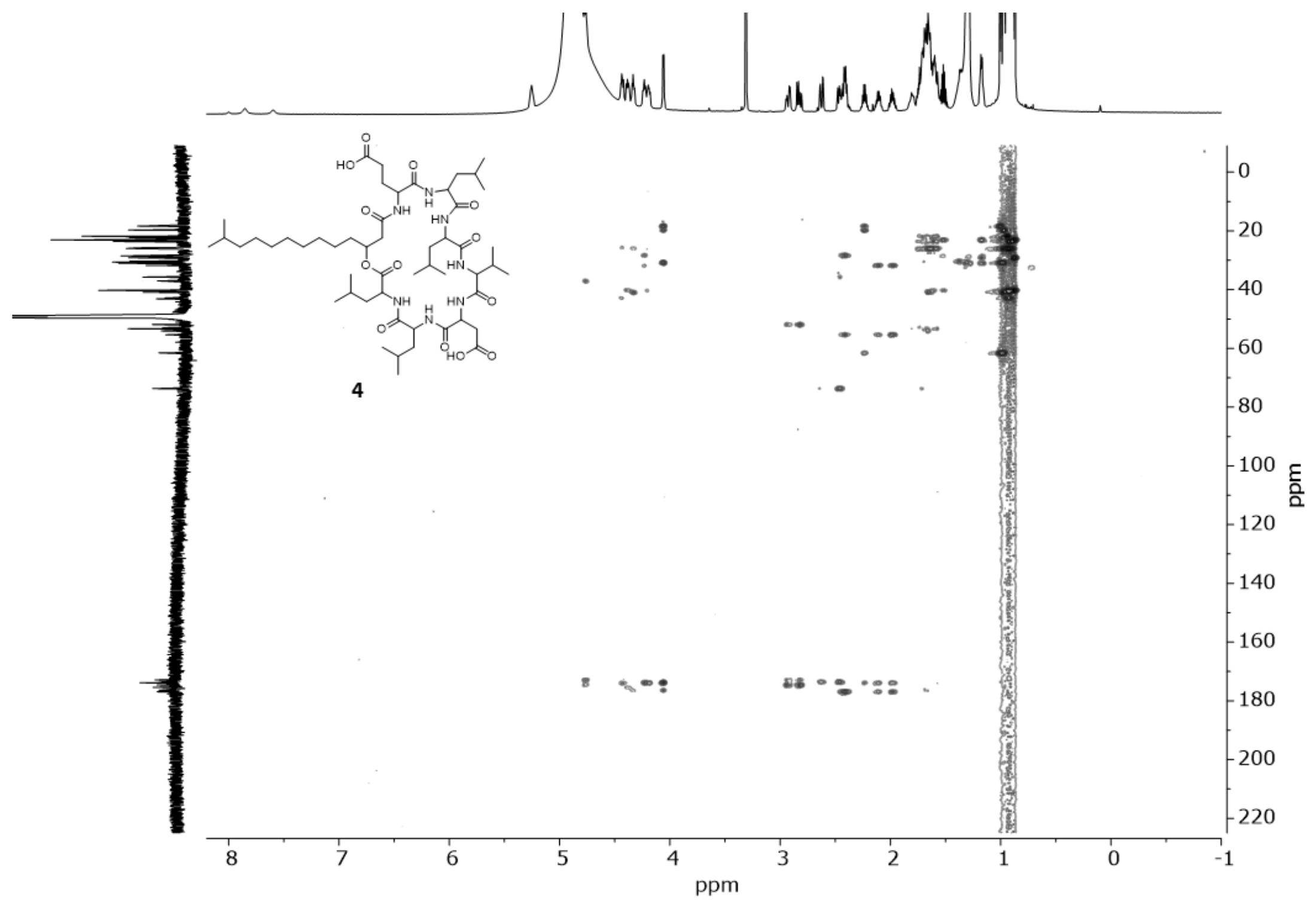

Figure S53. $\mathrm{HMBC}\left({ }^{1} \mathrm{H}-{ }^{13} \mathrm{C}\right)$ spectrum of $\mathbf{4}$ in $\mathrm{MeOD}-\mathrm{d}_{4}$. 


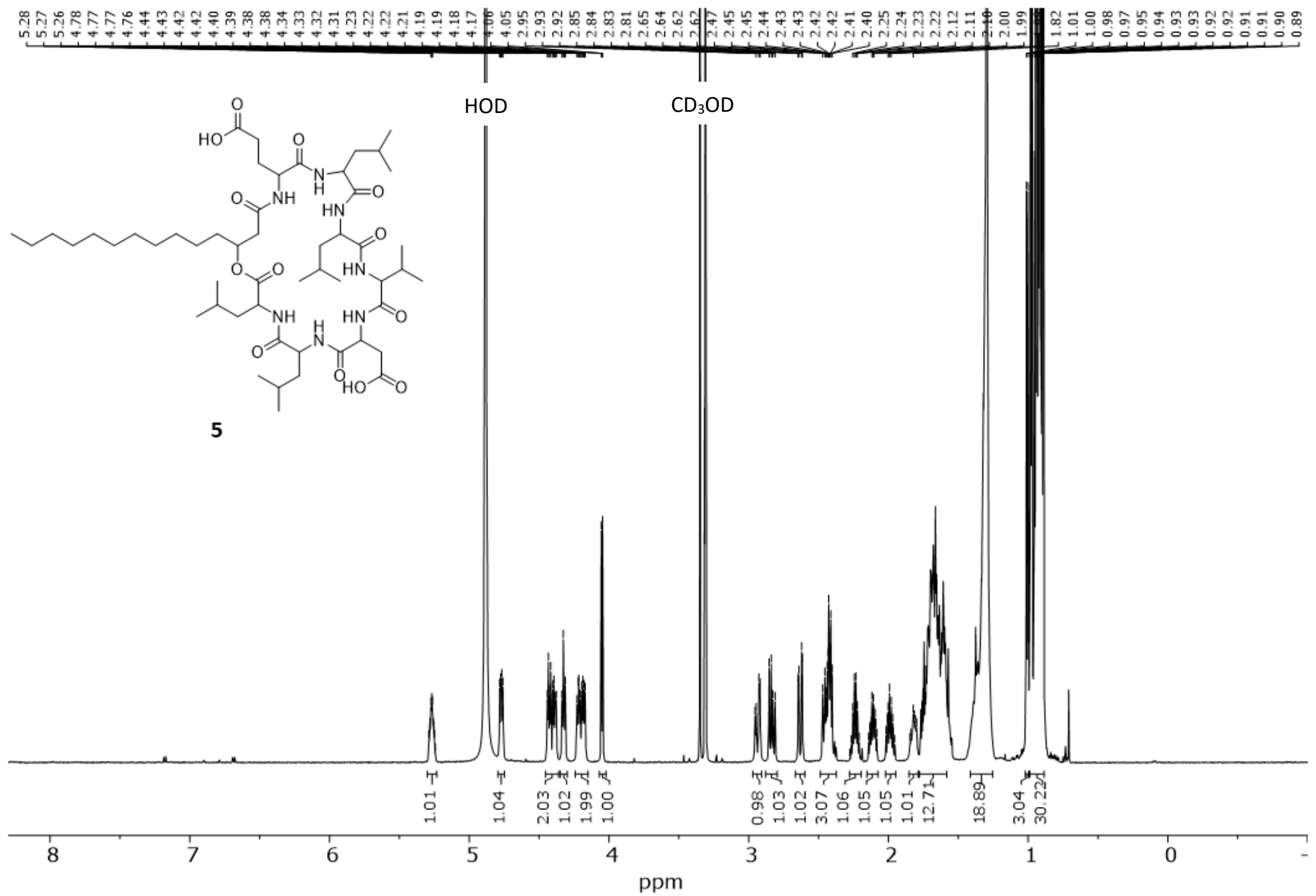

Figure S54. ${ }^{1} \mathrm{H}-\mathrm{NMR}$ spectrum of 5 in MeOD- $\mathrm{d}_{4}\left({ }^{1} \mathrm{H}: 600 \mathrm{MHz}\right)$. 
ம

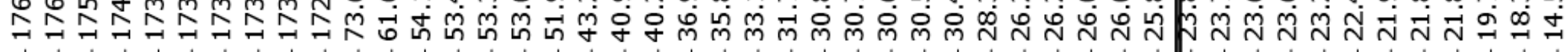

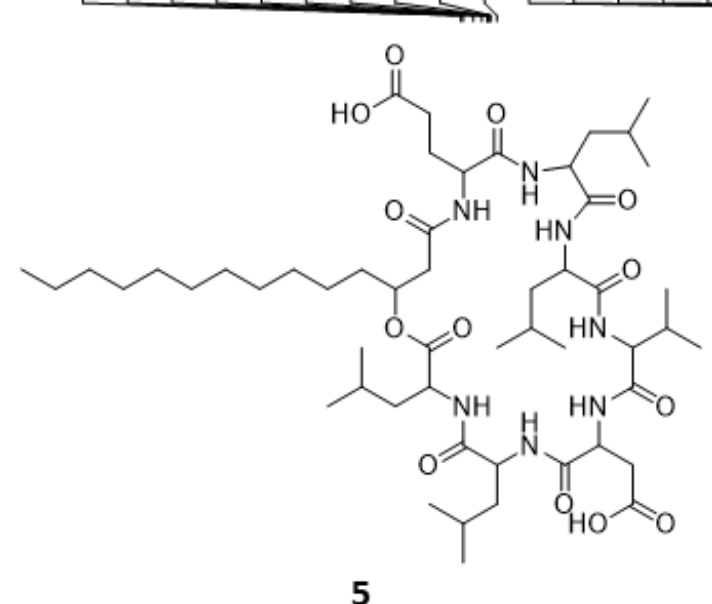

5

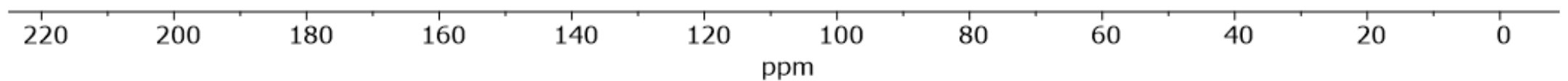

Figure S55. ${ }^{13} \mathrm{C}-\mathrm{NMR}$ spectrum of 5 in MeOD-d $\mathrm{d}_{4}\left({ }^{13} \mathrm{C}: 150 \mathrm{MHz}\right)$. 


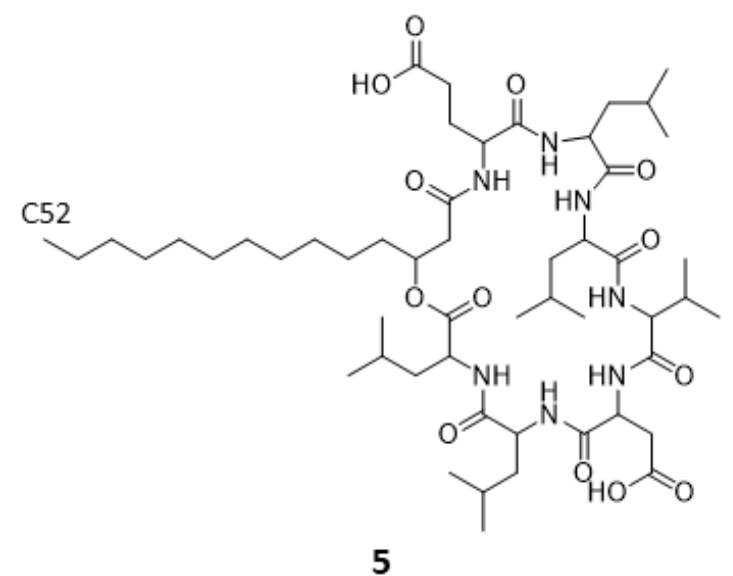

5

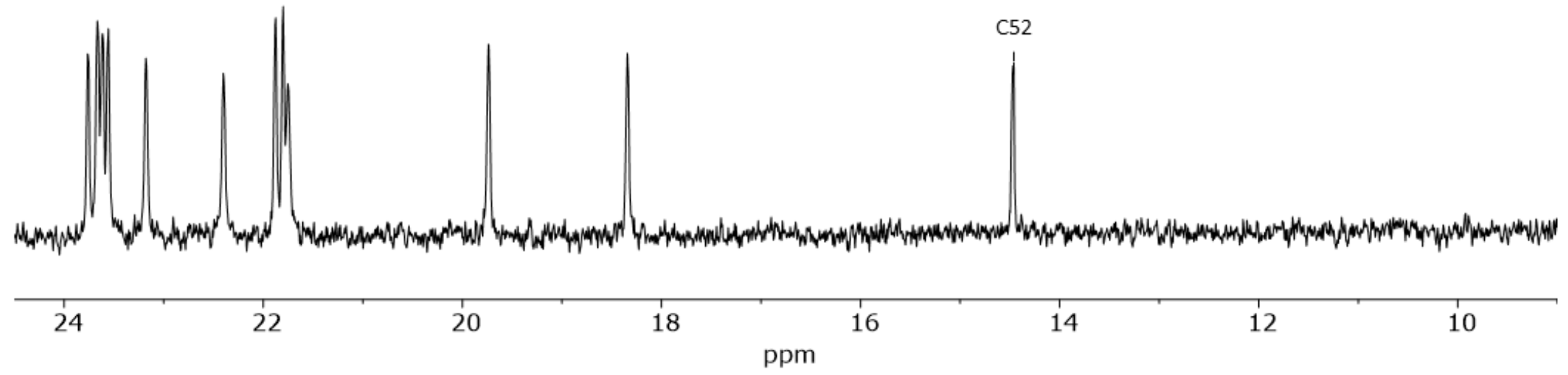

Figure S56. ${ }^{13} \mathrm{C}-\mathrm{NMR}$ spectrum of $\mathbf{5}$ in MeOD- $\mathrm{d}_{4}\left({ }^{13} \mathrm{C}: 150 \mathrm{MHz}\right)$, illustrating important methyl peaks used to determine chain branching. 


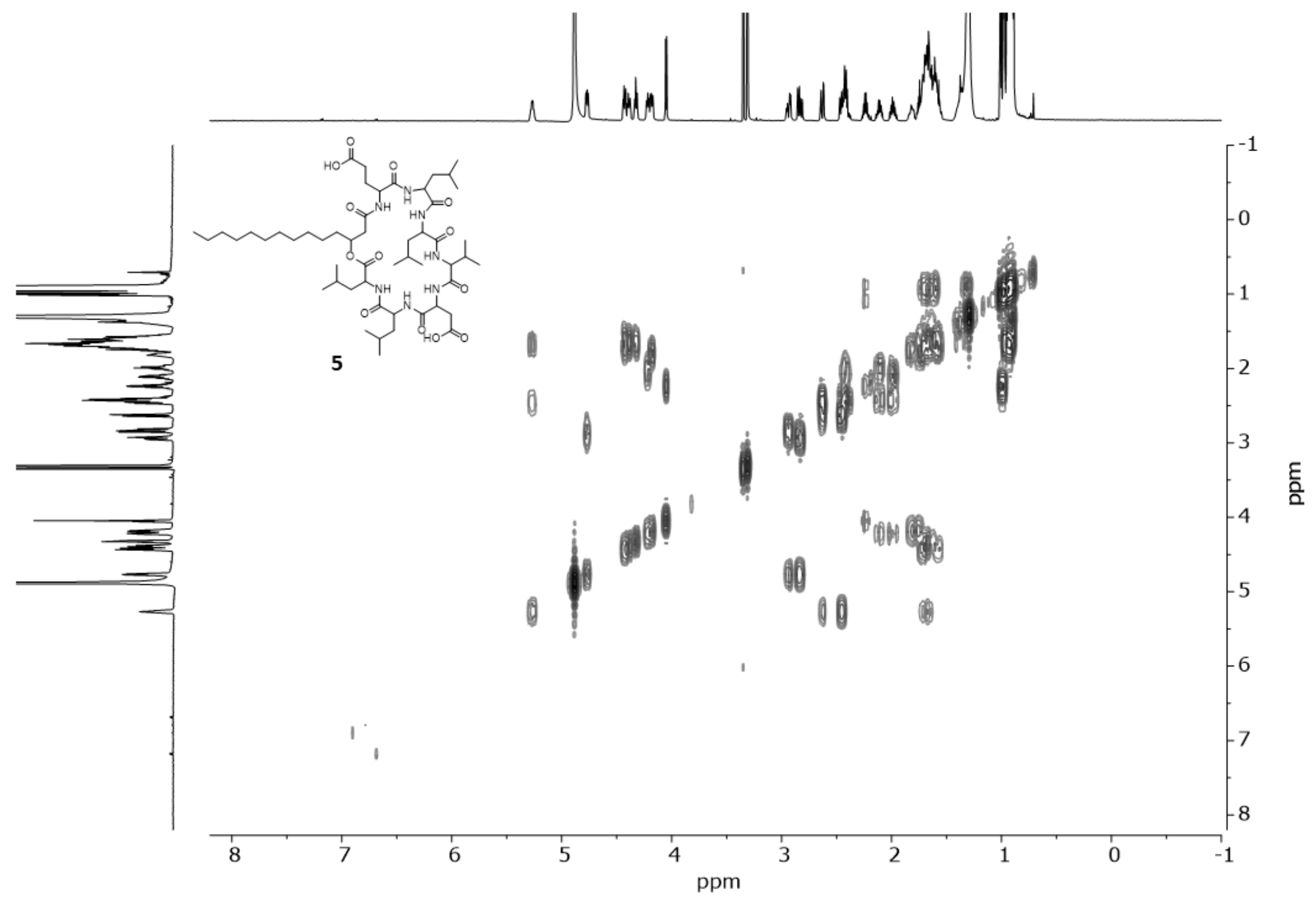

Figure S57. $\operatorname{COSY}\left({ }^{1} \mathrm{H}-{ }^{-1} \mathrm{H}\right)$ spectrum of 5 in MeOD-d $(600 \mathrm{MHz})$. 


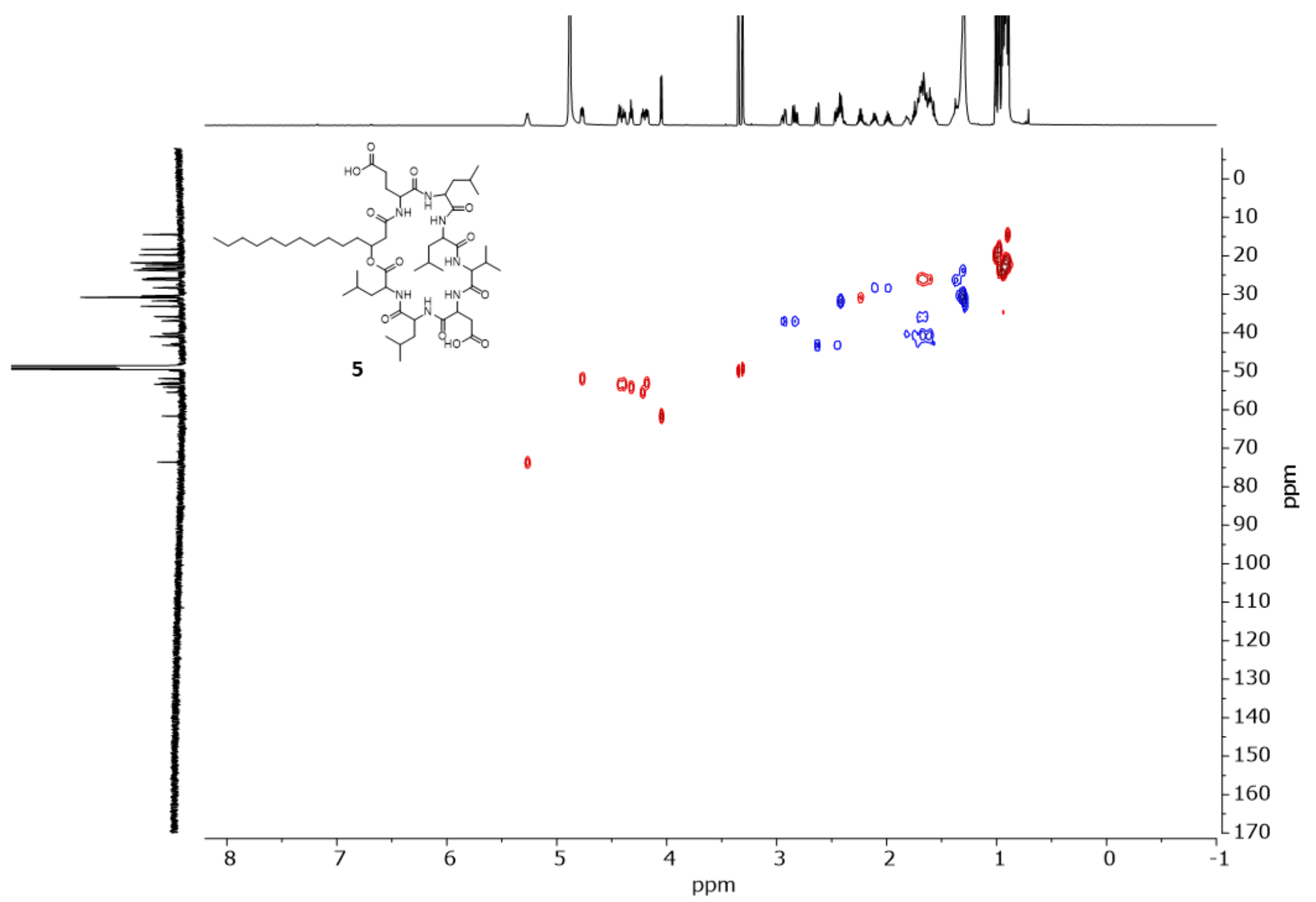

Figure S58. HSQC $\left({ }^{1} \mathrm{H}-{ }^{13} \mathrm{C}\right)$ spectrum of 5 in MeOD- $\mathrm{d}_{4}$. Red contours represent $\mathrm{CH}$ and $\mathrm{CH}_{3}$ groups, blue contours represent $\mathrm{CH}_{2}$ groups. 


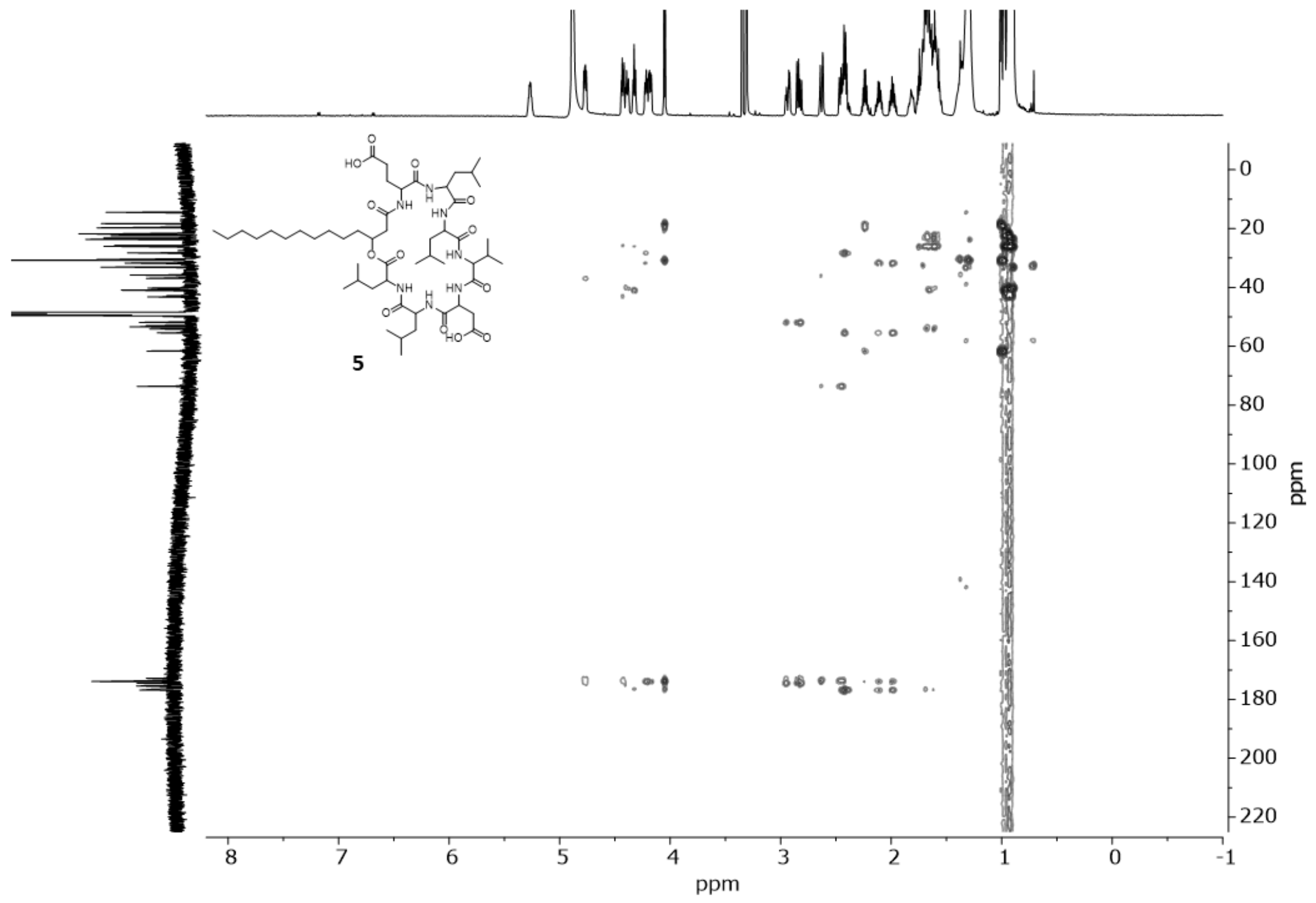

Figure S59. $\mathrm{HMBC}\left({ }^{1} \mathrm{H}-{ }^{13} \mathrm{C}\right)$ spectrum of 5 in MeOD- $\mathrm{d}_{4}$. 


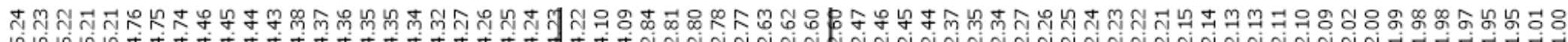

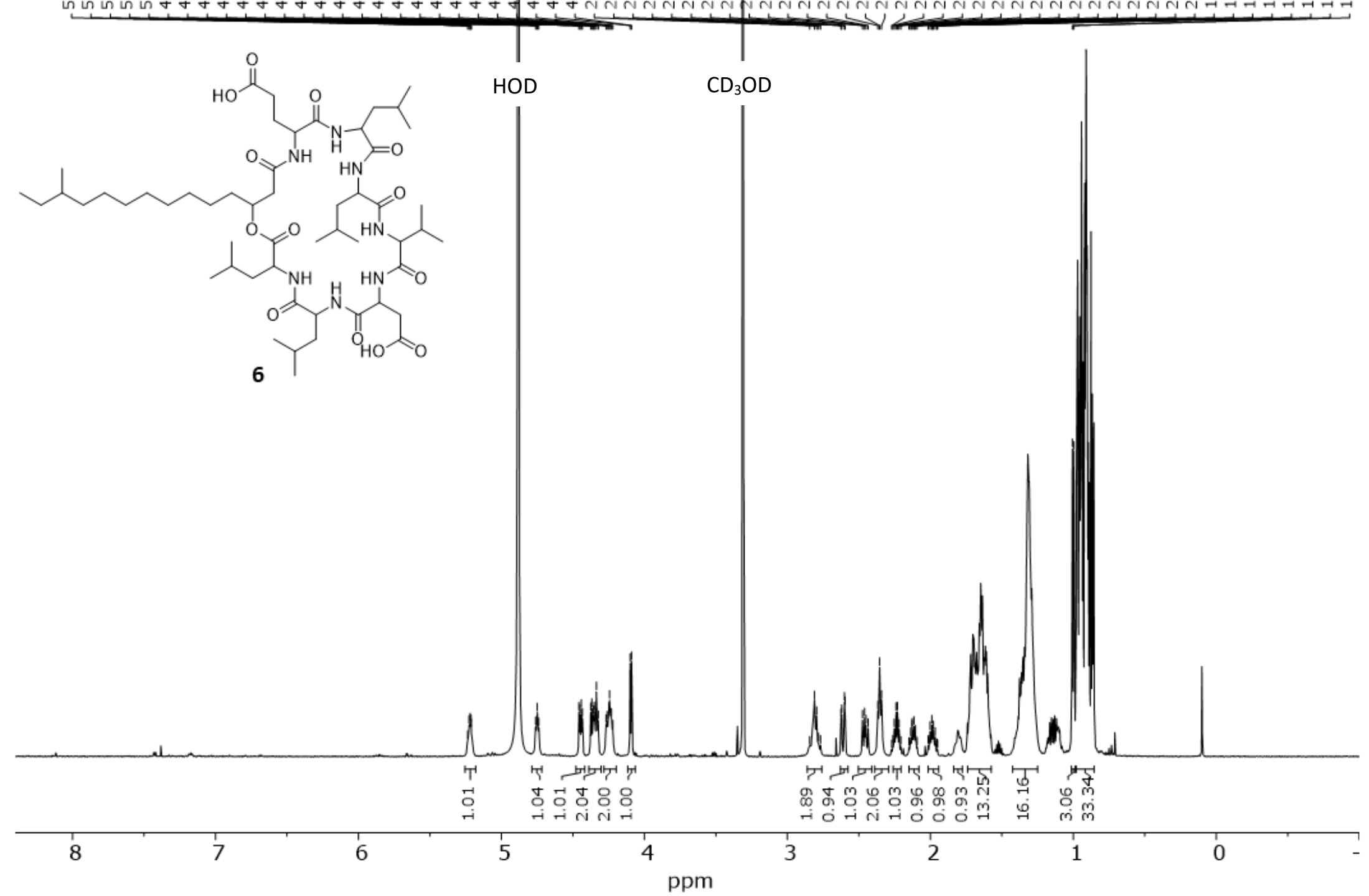

Figure S60. ${ }^{1} \mathrm{H}-\mathrm{NMR}$ spectrum of 6 in MeOD-d ${ }_{4}\left({ }^{1} \mathrm{H}: 600 \mathrm{MHz}\right)$. 

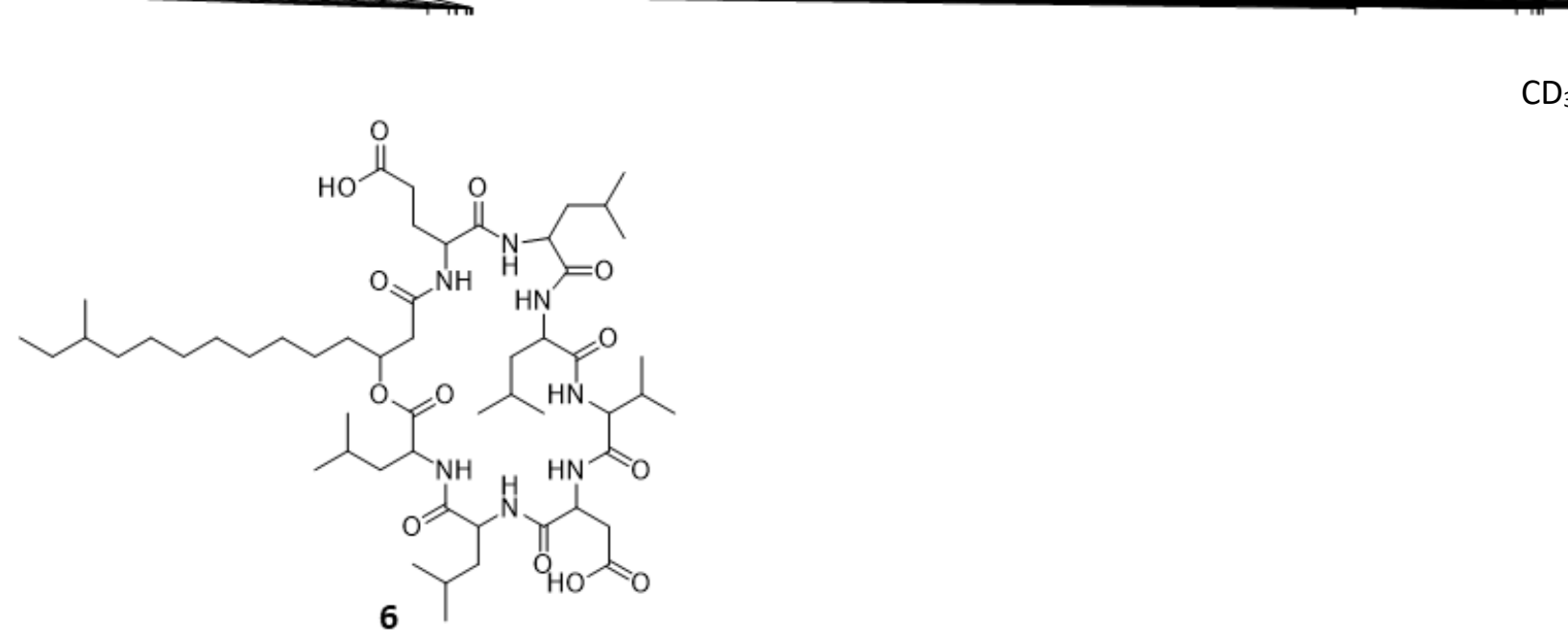

$\mathrm{CD}_{3} \mathrm{OD}$

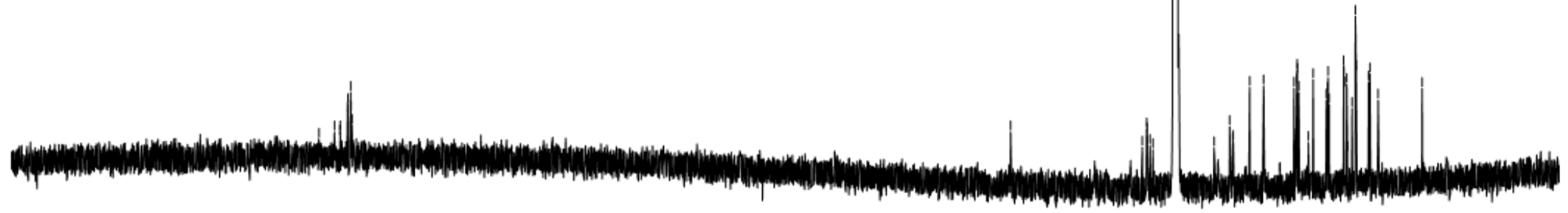

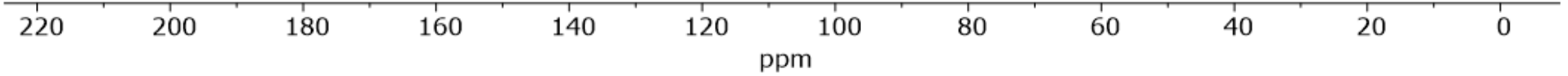

Figure S61. ${ }^{13} \mathrm{C}-\mathrm{NMR}$ spectrum of 6 in MeOD- $\mathrm{d}_{4}\left({ }^{13} \mathrm{C}: 150 \mathrm{MHz}\right)$. 

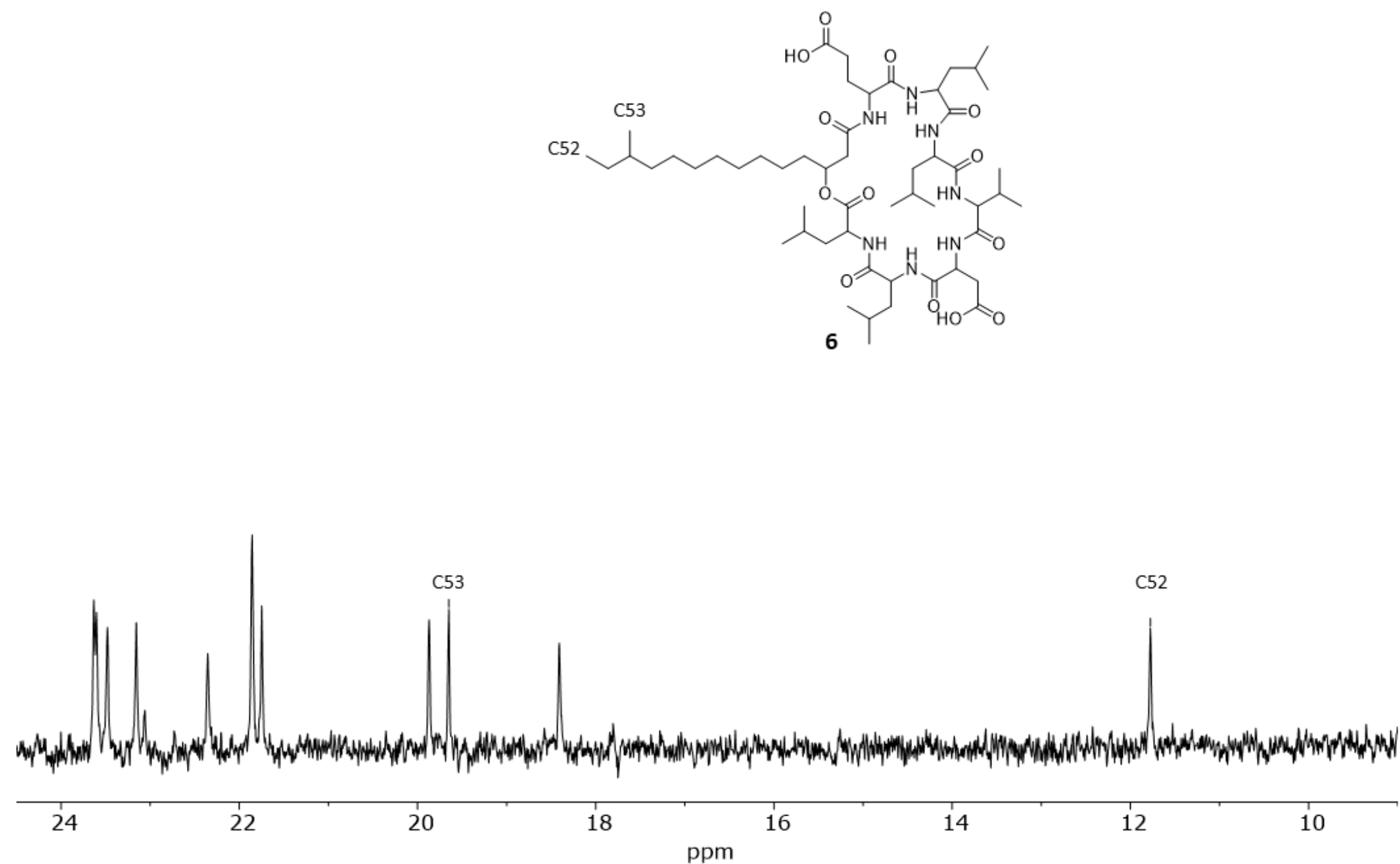

Figure S62. ${ }^{13} \mathrm{C}-\mathrm{NMR}$ spectrum of 6 in MeOD- $\mathrm{d}_{4}\left({ }^{13} \mathrm{C}: 150 \mathrm{MHz}\right)$, illustrating important methyl peaks used to determine chain branching. 


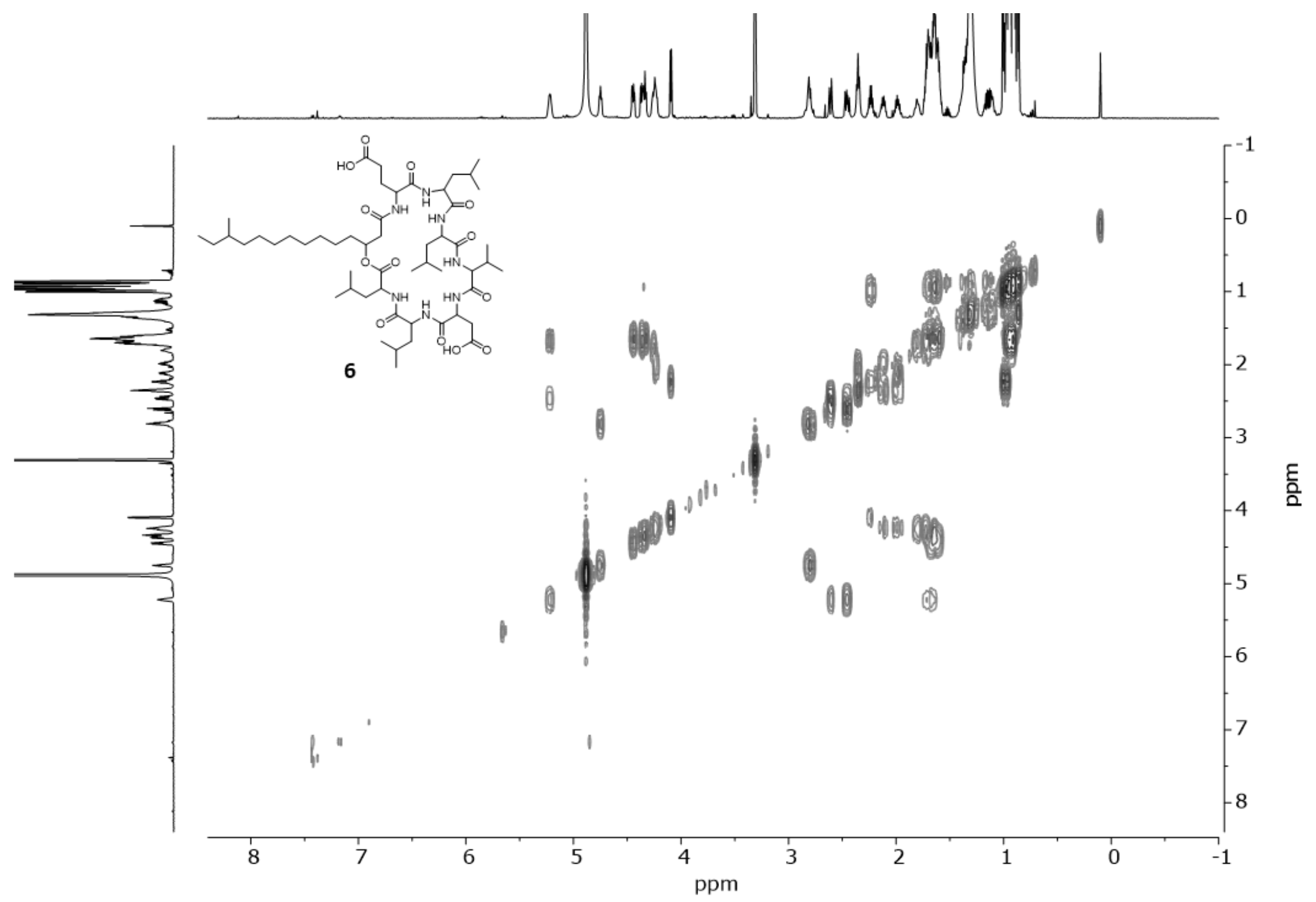

Figure S63. $\operatorname{COSY}\left({ }^{1} \mathrm{H}-{ }^{1} \mathrm{H}\right)$ spectrum of 6 in MeOD- $\mathrm{d}_{4}(600 \mathrm{MHz})$. 


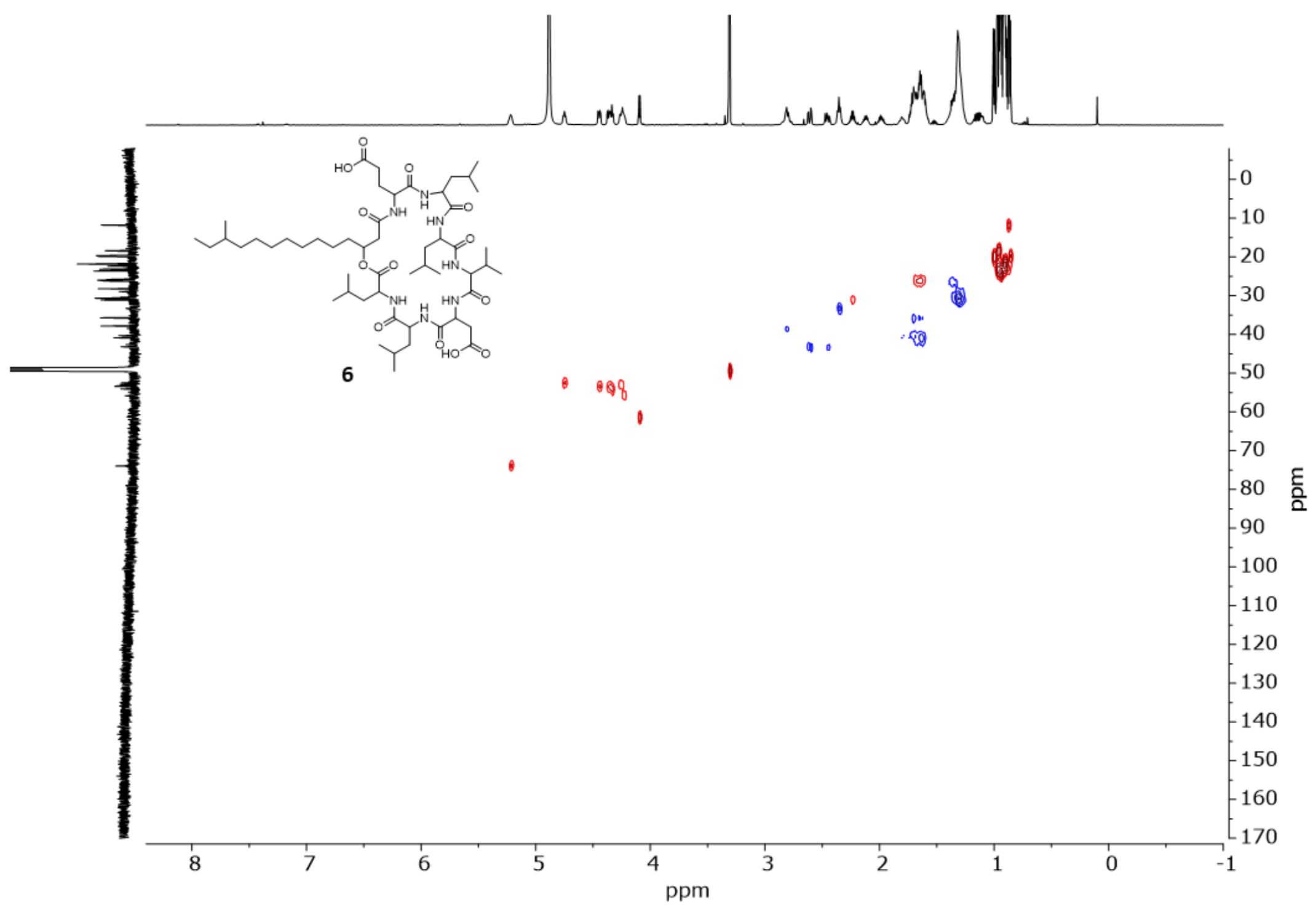

Figure S64. $\mathrm{HSQC}\left({ }^{1} \mathrm{H}-{ }^{13} \mathrm{C}\right)$ spectrum of 6 in MeOD- $\mathrm{d}_{4}$. Red contours represent $\mathrm{CH}$ and $\mathrm{CH}_{3}$ groups, blue contours represent $\mathrm{CH}_{2}$ groups. 


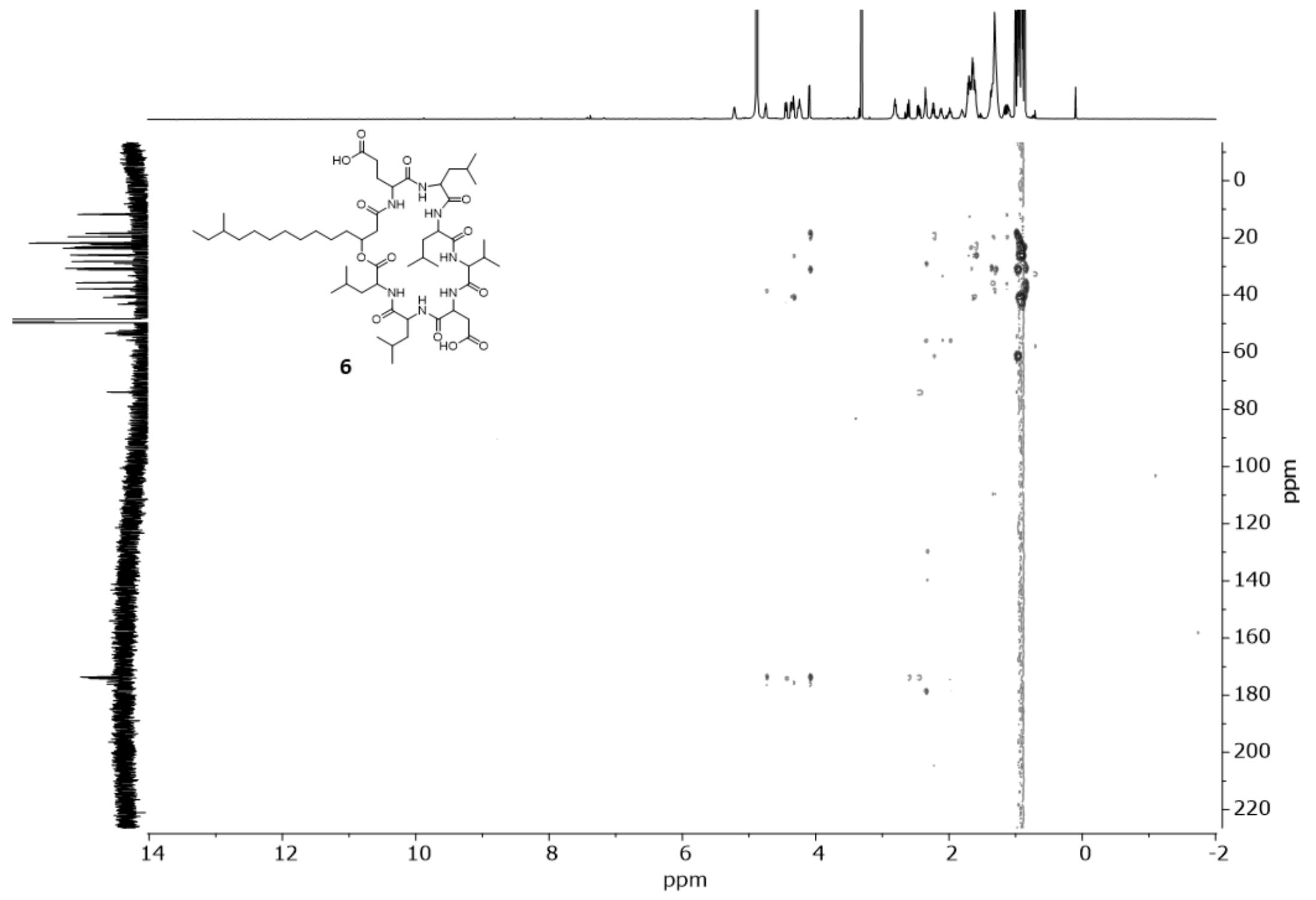

Figure S65. $\mathrm{HMBC}\left({ }^{1} \mathrm{H}-{ }^{13} \mathrm{C}\right)$ spectrum of 6 in MeOD- $\mathrm{d}_{4}$. 


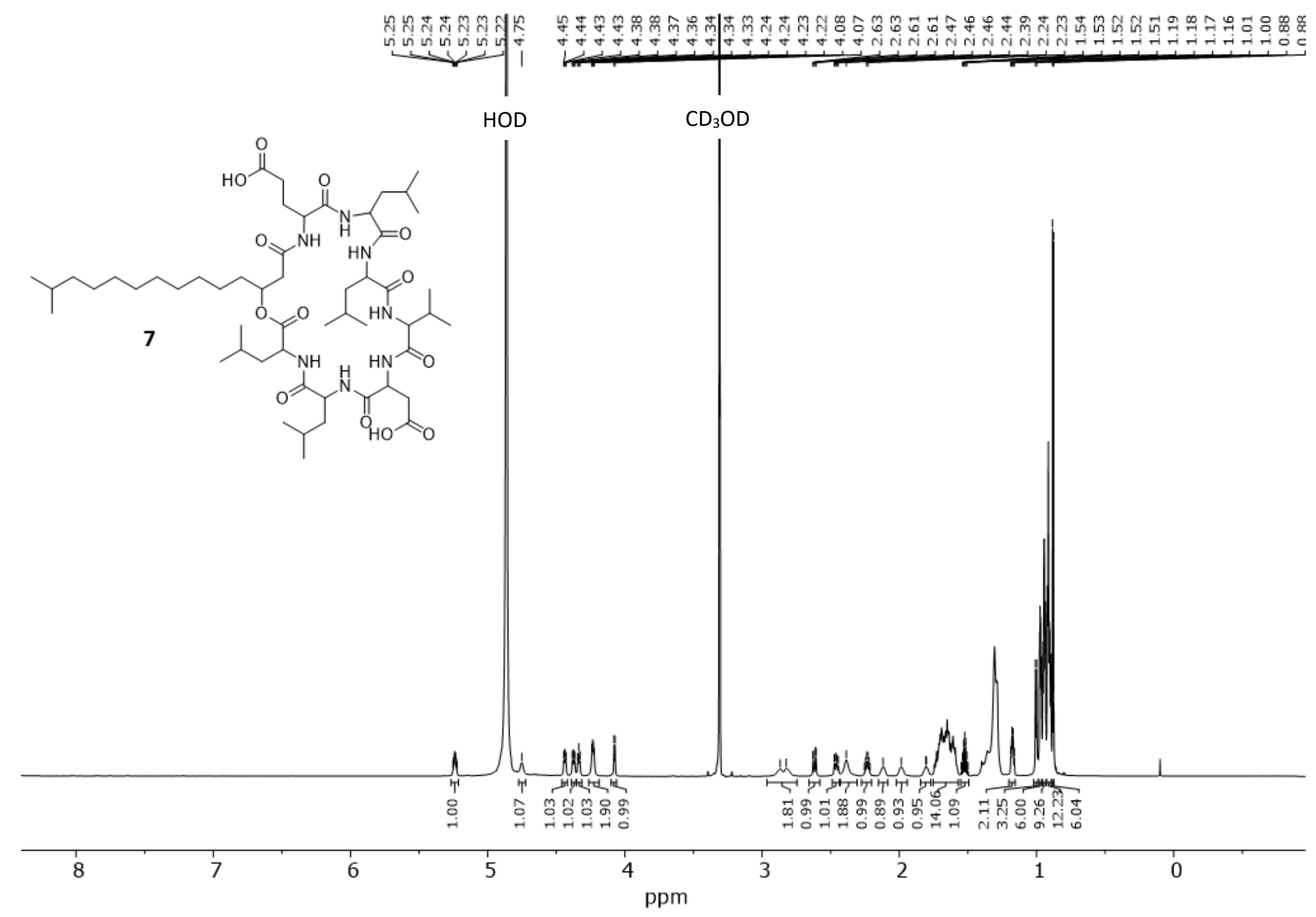

Figure S66. ${ }^{1} \mathrm{H}-\mathrm{NMR}$ spectrum of 7 in MeOD- $\mathrm{d}_{4}\left({ }^{1} \mathrm{H}: 800 \mathrm{MHz}\right)$. 


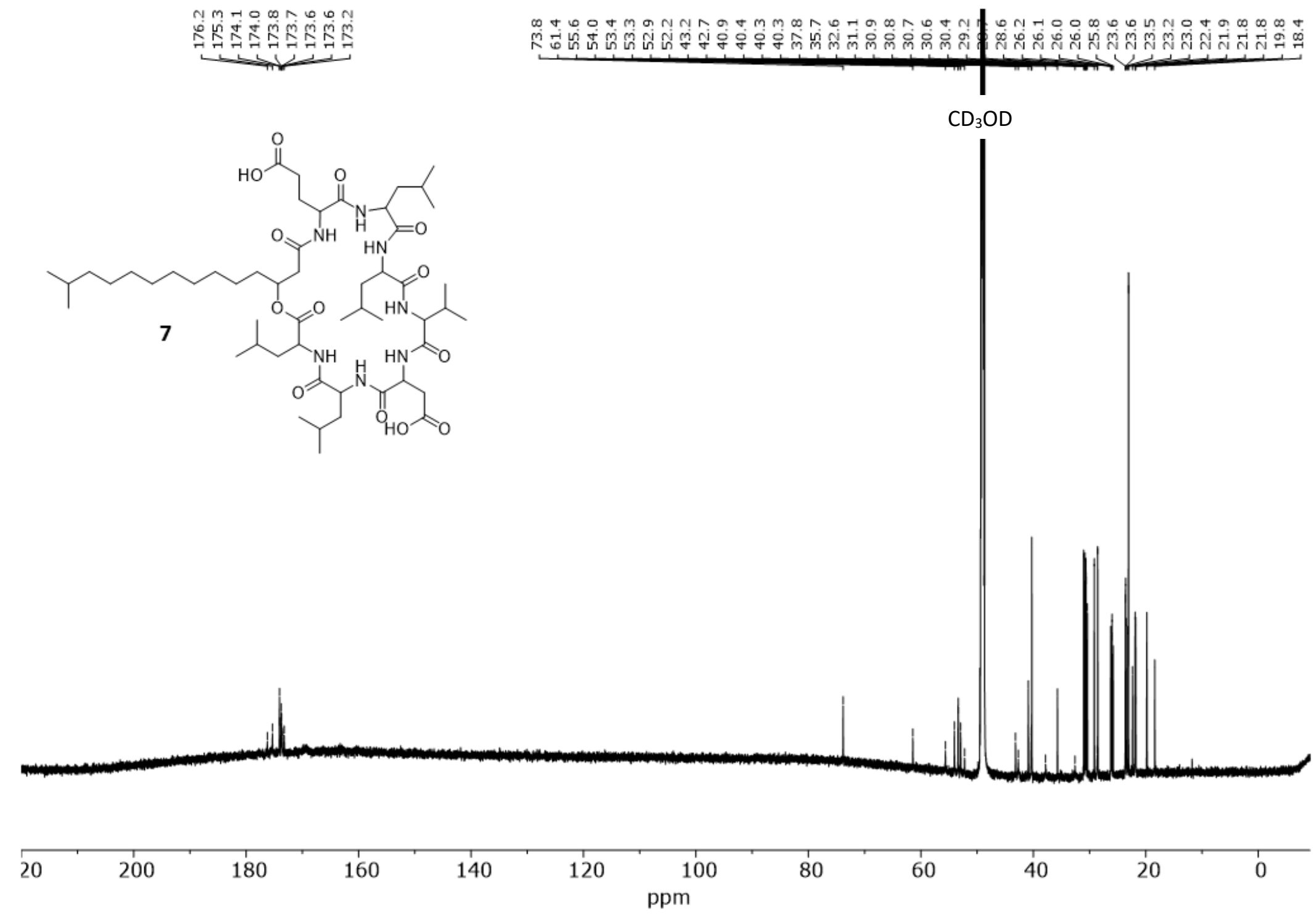

Figure S67. ${ }^{13} \mathrm{C}-\mathrm{NMR}$ spectrum of $\mathbf{7}$ in MeOD-d $\mathrm{d}_{4}\left({ }^{13} \mathrm{C}: 200 \mathrm{MHz}\right)$. 
$\stackrel{\circ}{\text { N }}$

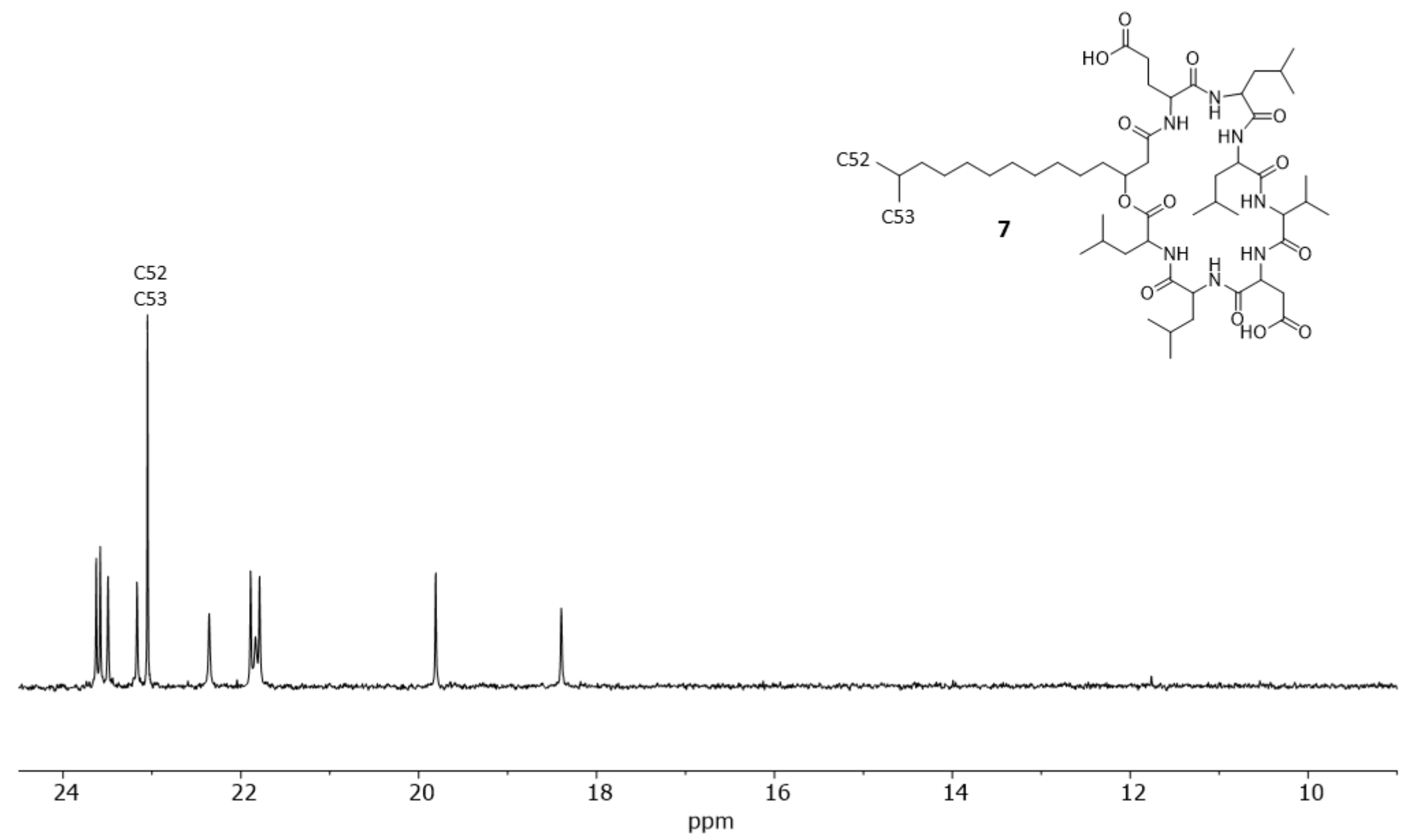

Figure S68. ${ }^{13} \mathrm{C}-\mathrm{NMR}$ spectrum of $\mathbf{7}$ in MeOD- $\mathrm{d}_{4}\left({ }^{13} \mathrm{C}: 200 \mathrm{MHz}\right)$, illustrating important methyl peaks used to determine chain branching. 


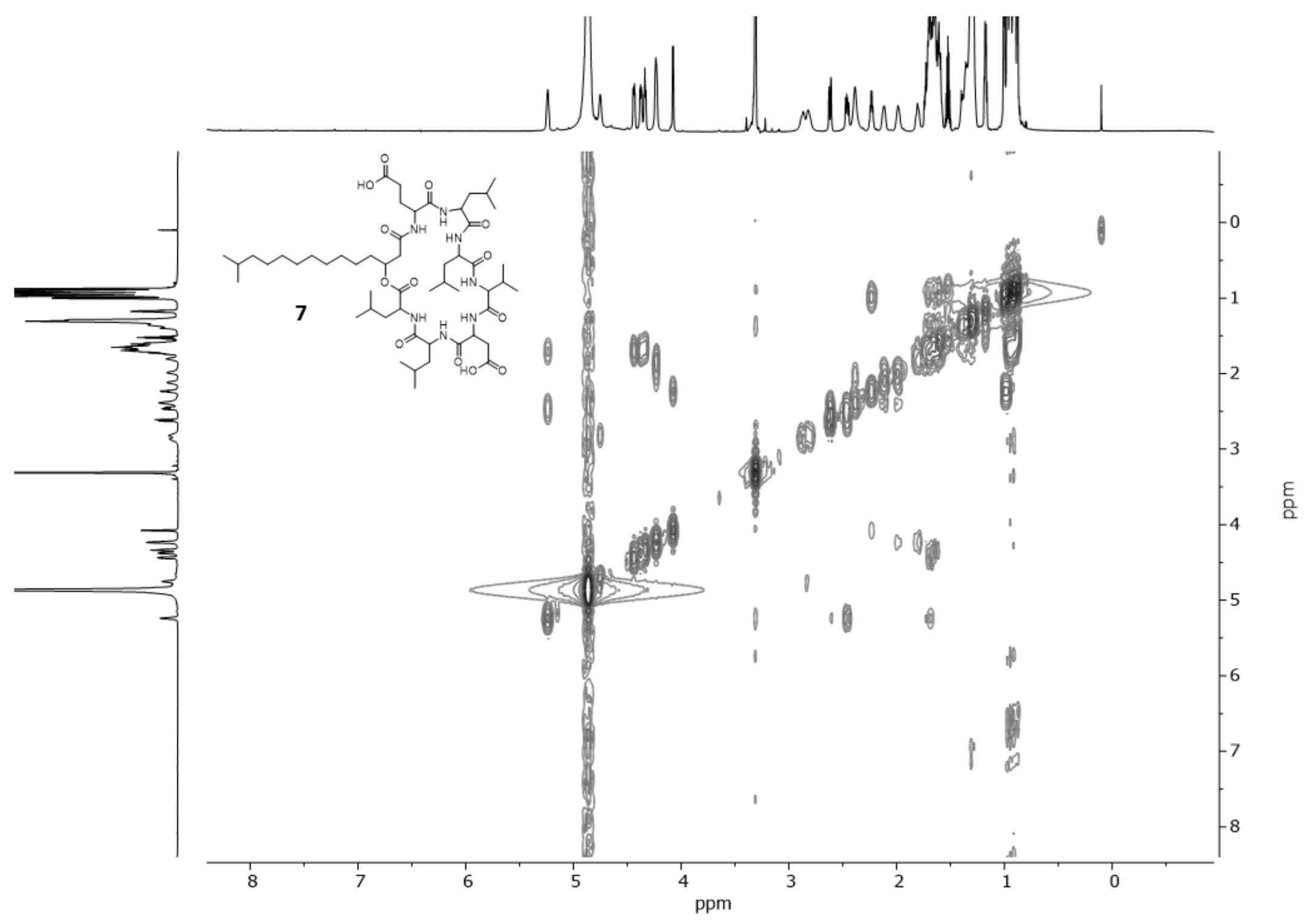

Figure S69. $\operatorname{COSY}\left({ }^{1} \mathrm{H}^{-1} \mathrm{H}\right)$ spectrum of $\mathbf{7}$ in $\mathrm{MeOD}-\mathrm{d}_{4}(800 \mathrm{MHz})$. 


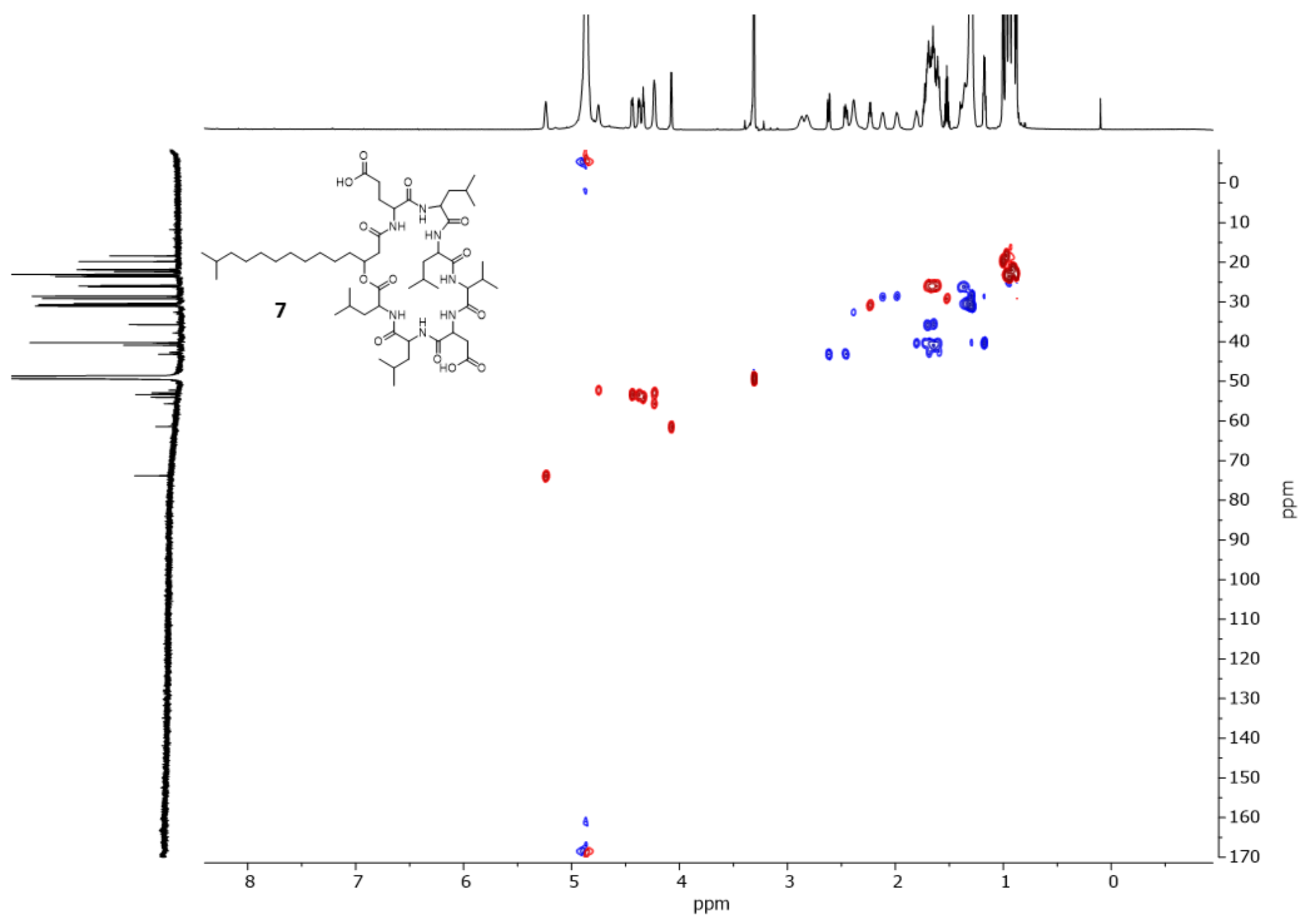

Figure S70. $\mathrm{HSQC}\left({ }^{1} \mathrm{H}^{13} \mathrm{C}\right)$ spectrum of 7 in MeOD- $\mathrm{d}_{4}$. Red contours represent $\mathrm{CH}$ and $\mathrm{CH}_{3}$ groups, blue contours represent $\mathrm{CH}_{2}$ groups. 


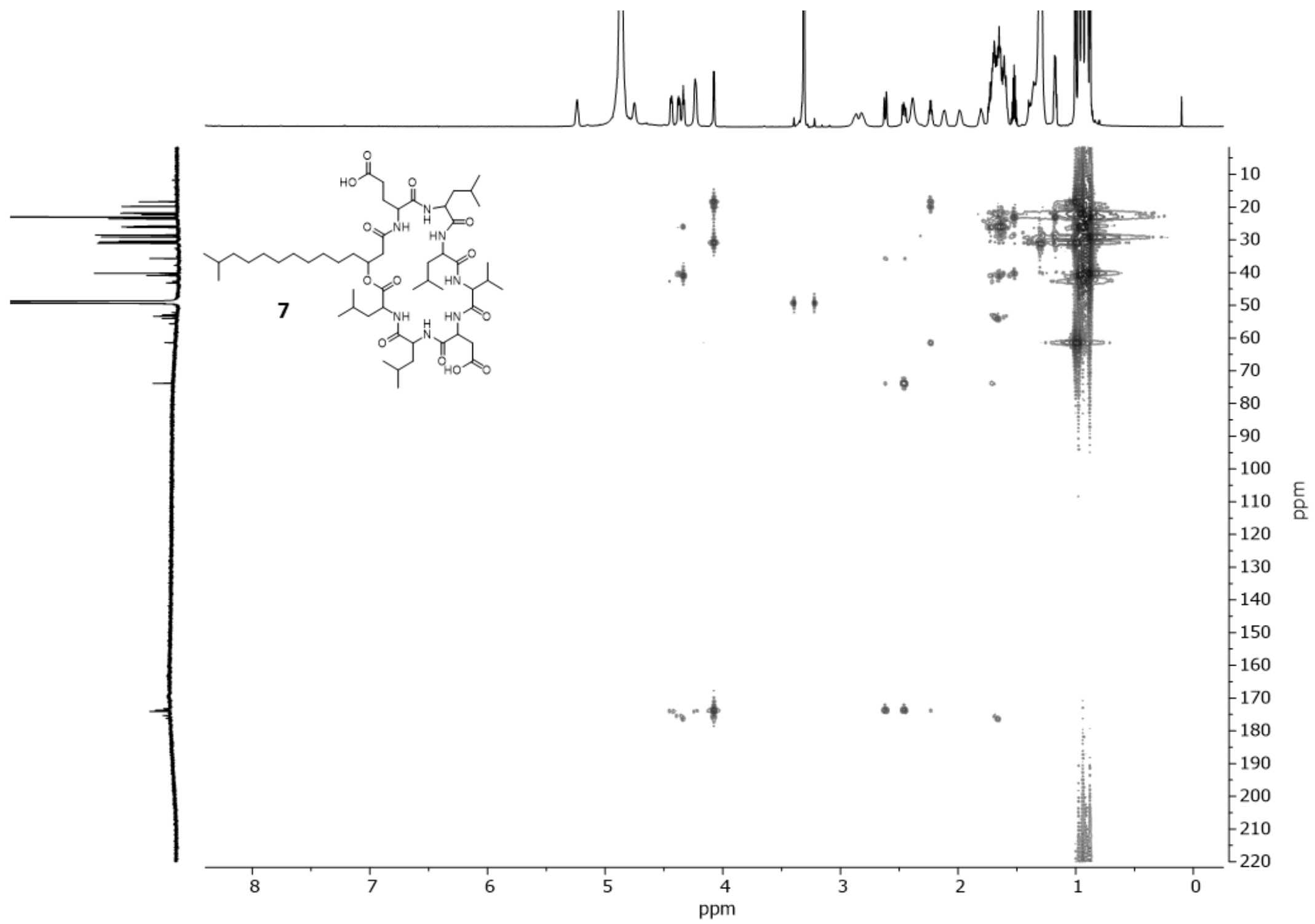

Figure S71. $\mathrm{HMBC}\left({ }^{1} \mathrm{H}^{-13} \mathrm{C}\right)$ spectrum of $\mathbf{7}$ in MeOD- $\mathrm{d}_{4}$.

S83 


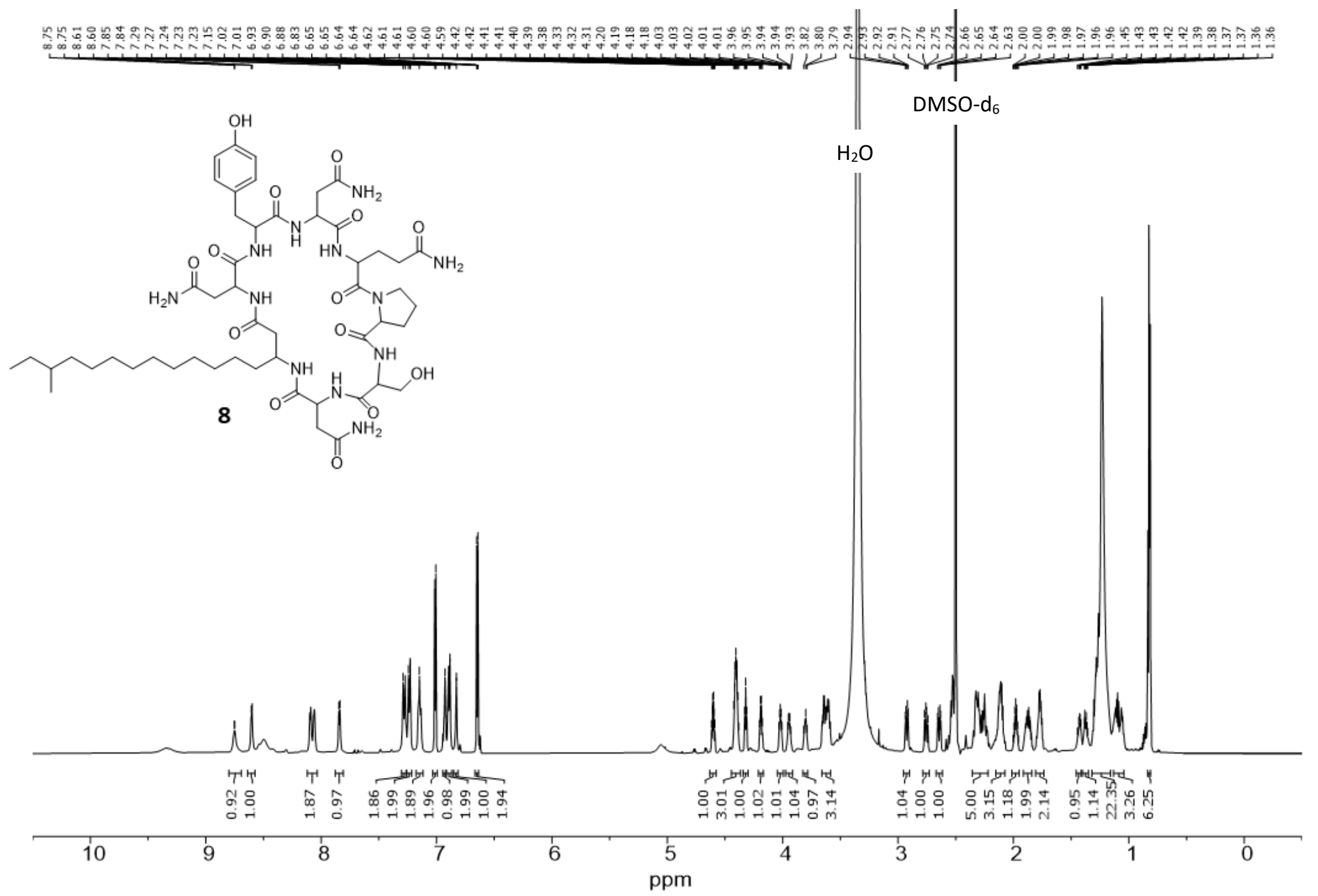

Figure S72. ${ }^{1} \mathrm{H}-\mathrm{NMR}$ spectrum of 8 in DMSO-d $\mathrm{d}_{6}\left({ }^{1} \mathrm{H}: 800 \mathrm{MHz}\right)$. 

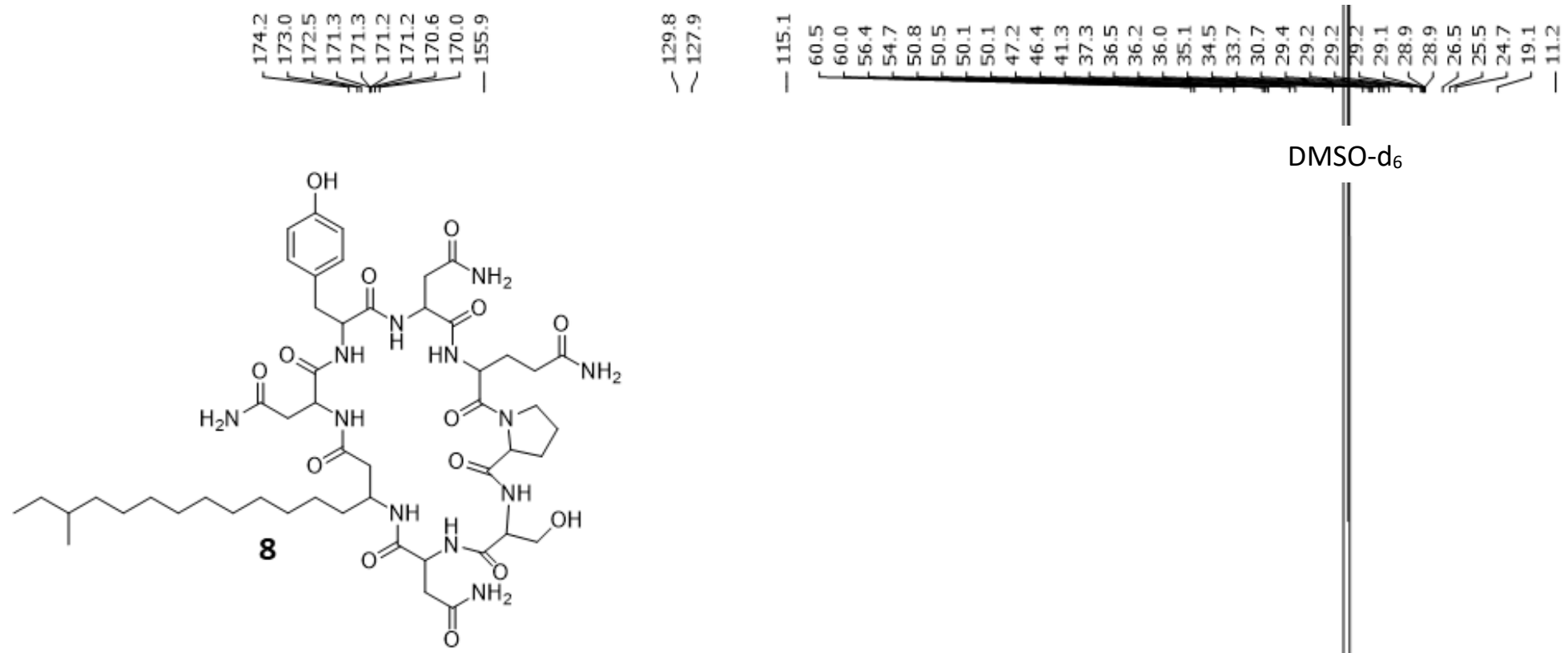

DMSO-d 6

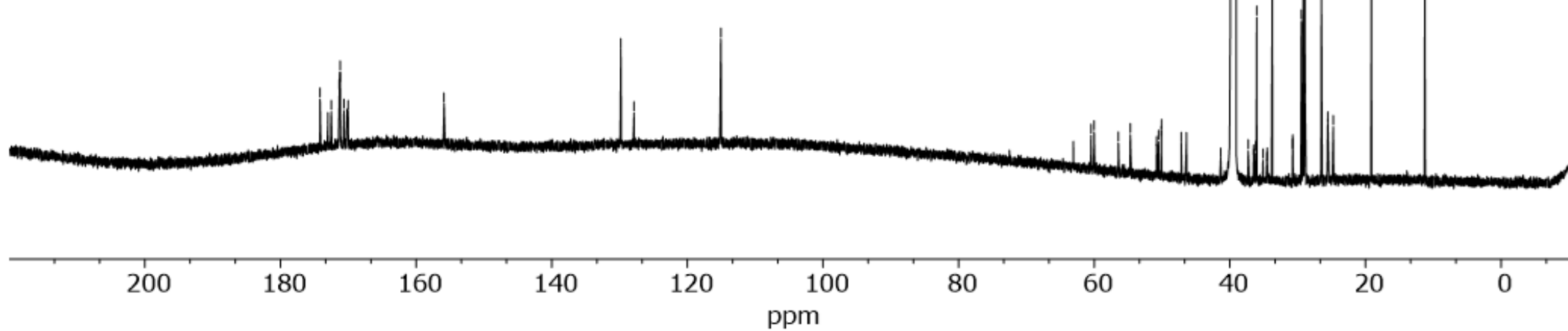

Figure S73. ${ }^{13} \mathrm{C}-\mathrm{NMR}$ spectrum of 8 in DMSO-d $6\left({ }^{13} \mathrm{C}: 200 \mathrm{MHz}\right)$. 

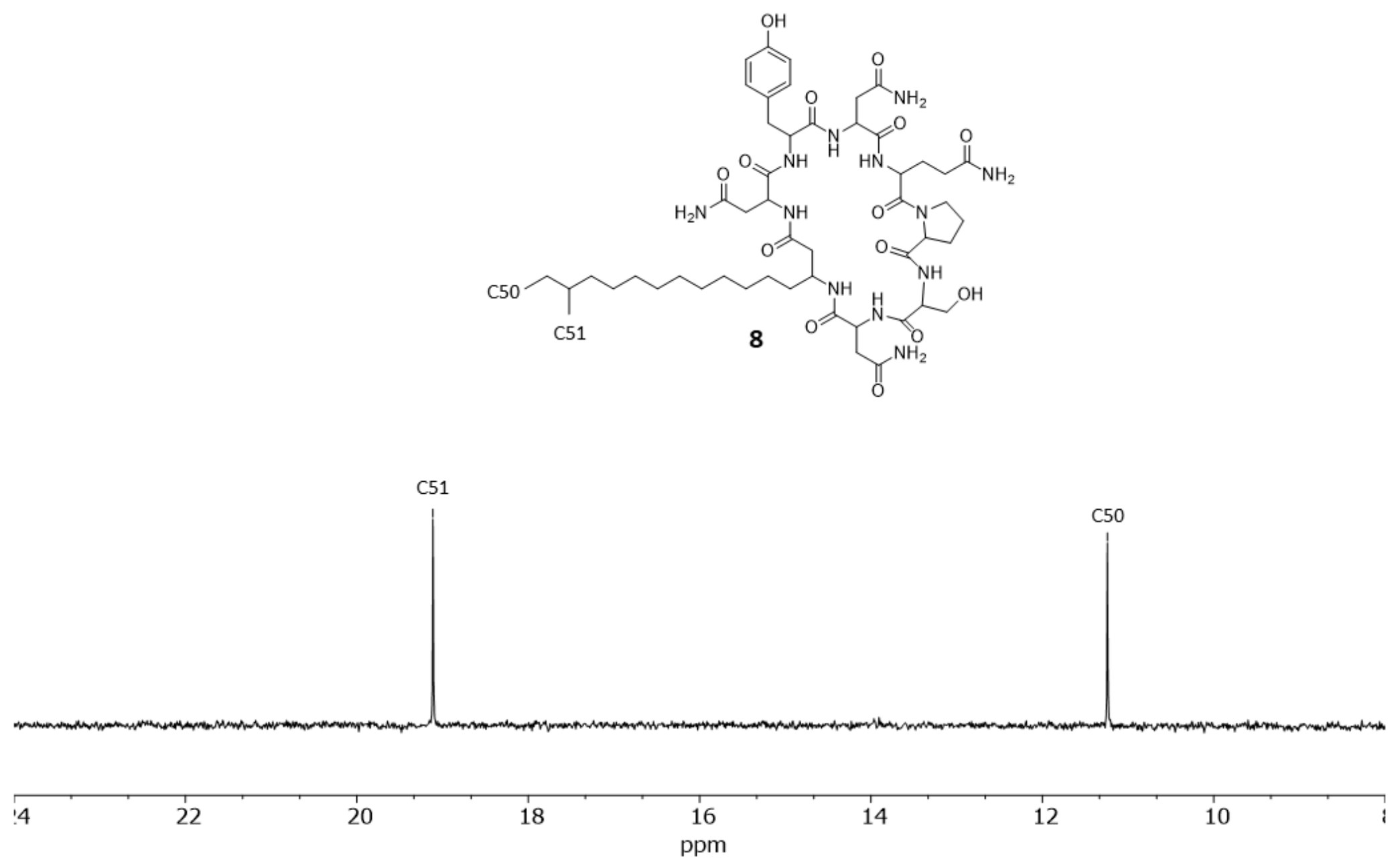

Figure S74. ${ }^{13} \mathrm{C}-\mathrm{NMR}$ spectrum of 8 in DMSO-d $6\left({ }^{13} \mathrm{C}: 200 \mathrm{MHz}\right)$, illustrating important methyl peaks used to determine chain branching. 


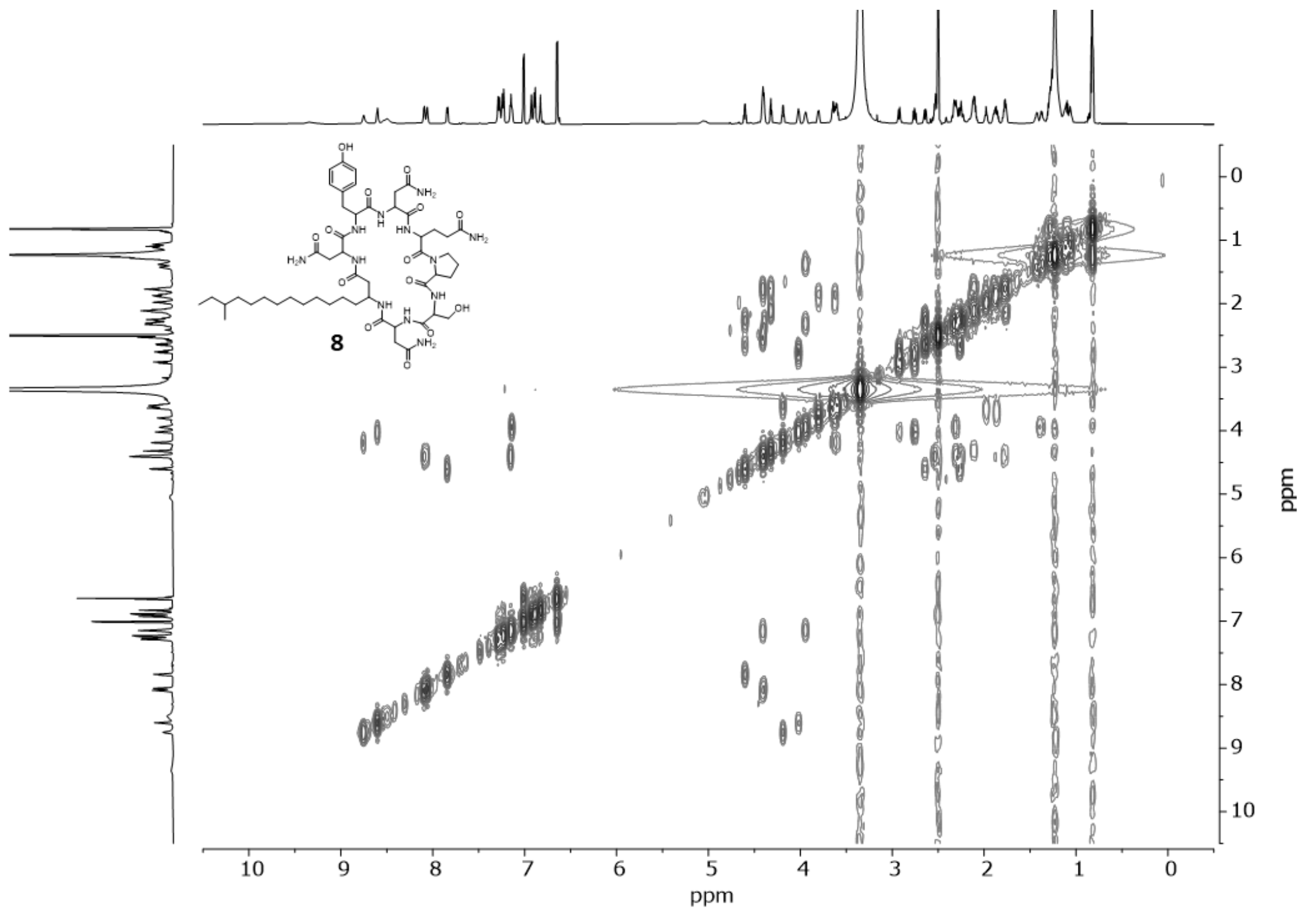

Figure S75. $\operatorname{COSY}\left({ }^{1} \mathrm{H}^{-1} \mathrm{H}\right)$ spectrum of 8 in DMSO- $\mathrm{d}_{6}(800 \mathrm{MHz})$. 


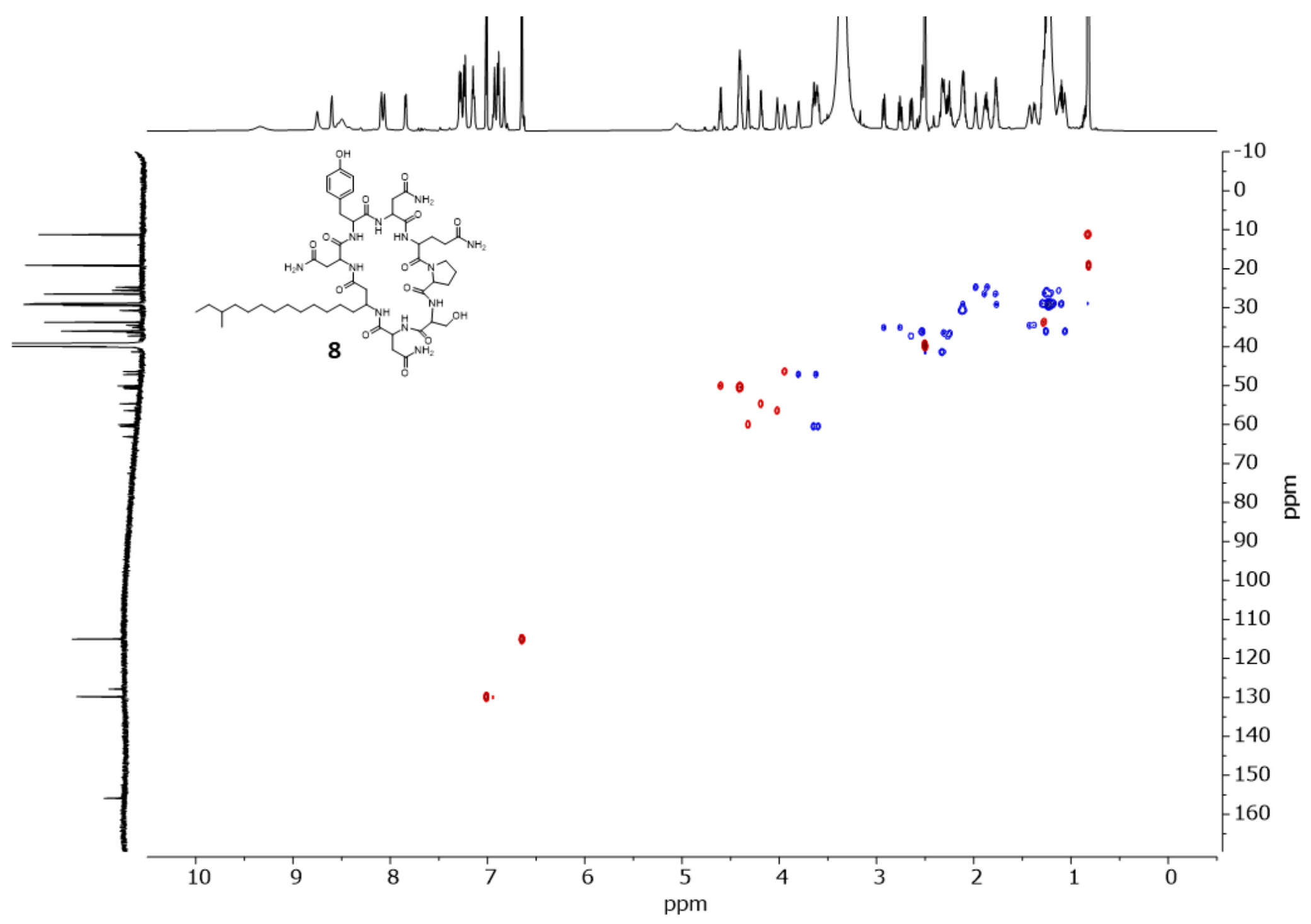

Figure S76. $\mathrm{HSQC}\left({ }^{1} \mathrm{H}^{13} \mathrm{C}\right)$ spectrum of 8 in DMSO-d $\mathrm{d}_{6}$. Red contours represent $\mathrm{CH}$ and $\mathrm{CH}_{3}$ groups, blue contours represent $\mathrm{CH}_{2}$ groups. 


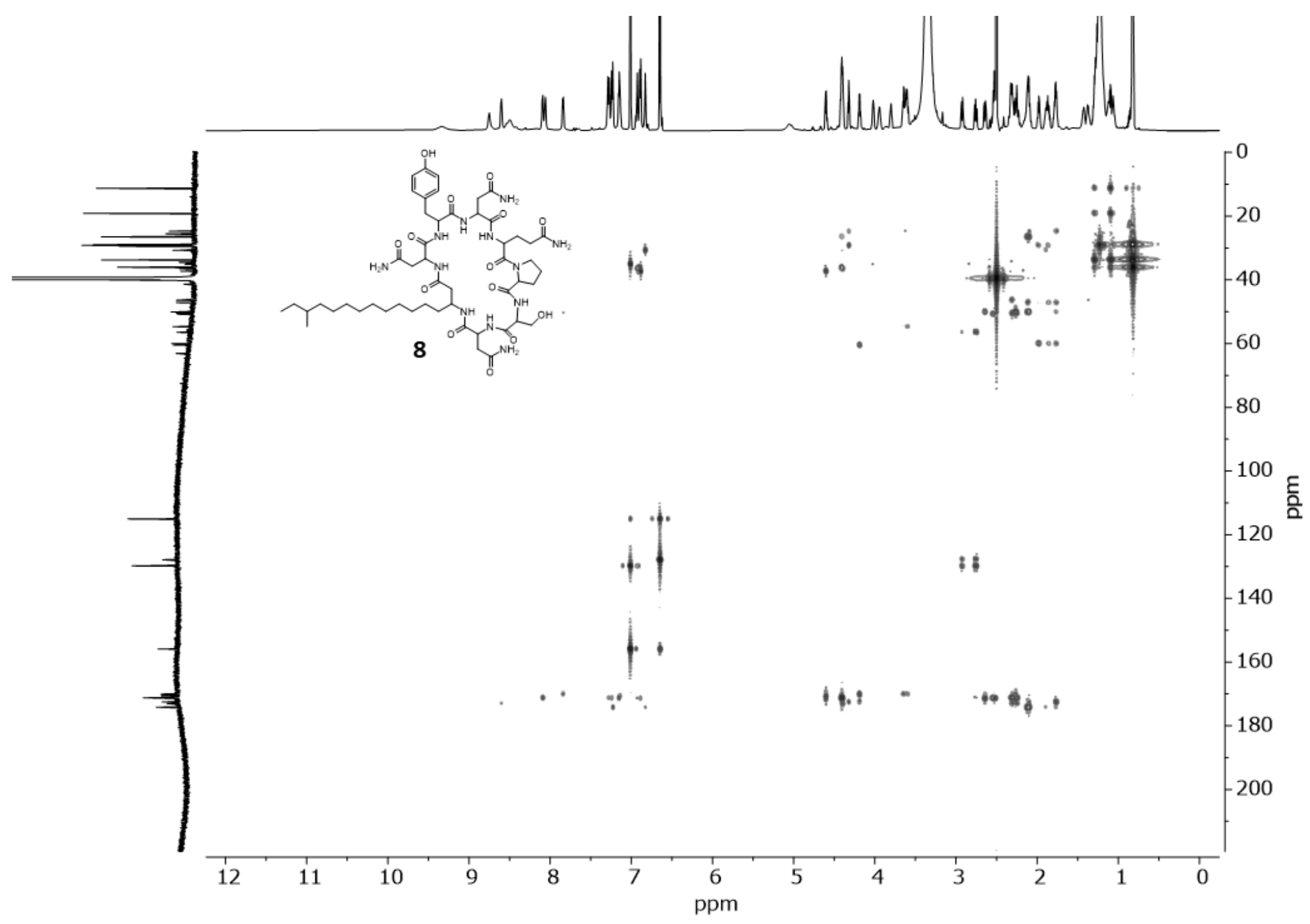

Figure S77. $\mathrm{HMBC}\left({ }^{1} \mathrm{H}_{-}{ }^{13} \mathrm{C}\right)$ spectrum of 8 in DMSO- $\mathrm{d}_{6}$. 


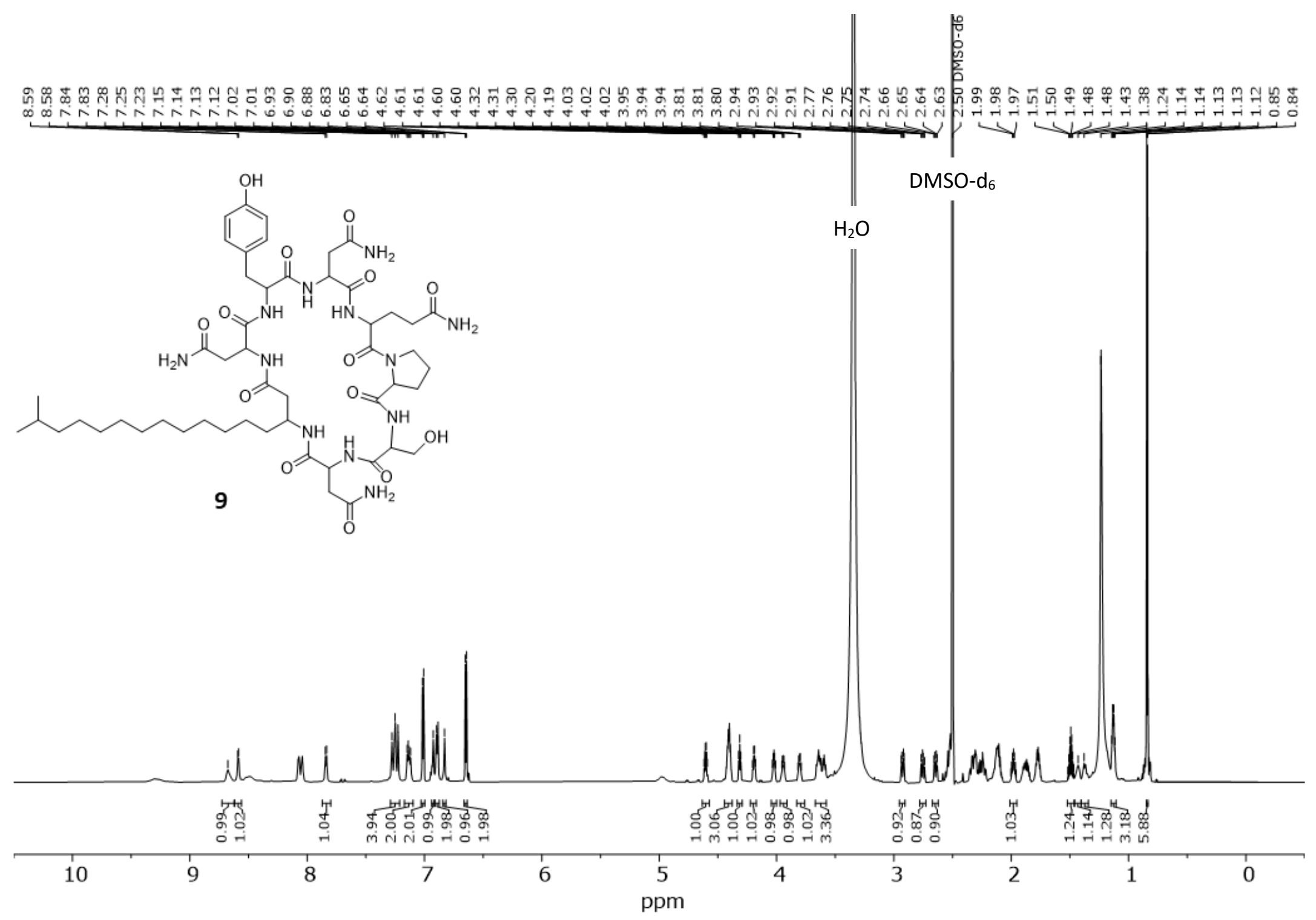

Figure S78. ${ }^{1} \mathrm{H}-\mathrm{NMR}$ spectrum of 9 in DMSO- $\mathrm{d}_{6}\left({ }^{1} \mathrm{H}: 800 \mathrm{MHz}\right)$. 


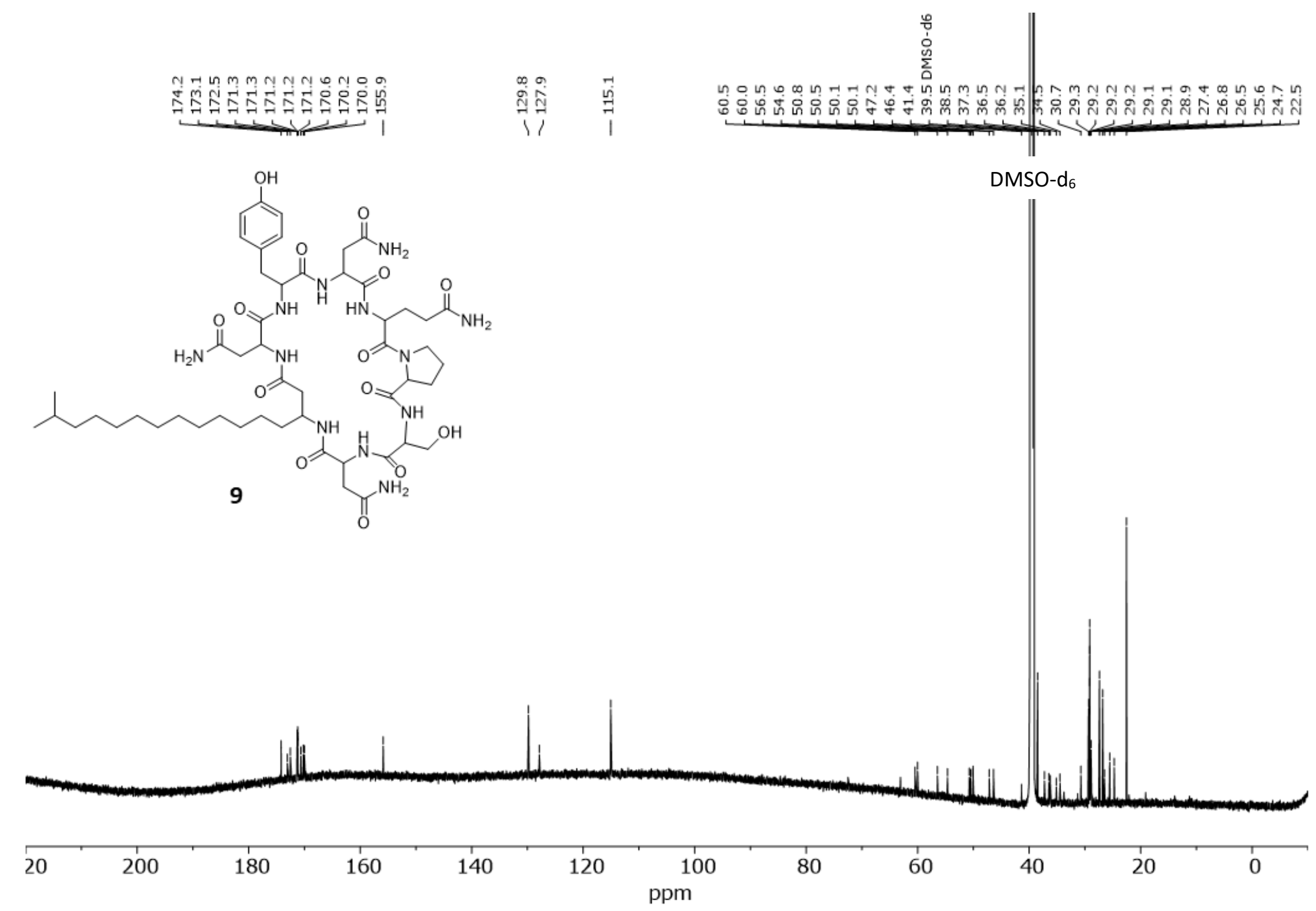

Figure S79. ${ }^{13} \mathrm{C}-\mathrm{NMR}$ spectrum of 9 in DMSO- $\mathrm{d}_{6}\left({ }^{13} \mathrm{C}: 200 \mathrm{MHz}\right)$. 


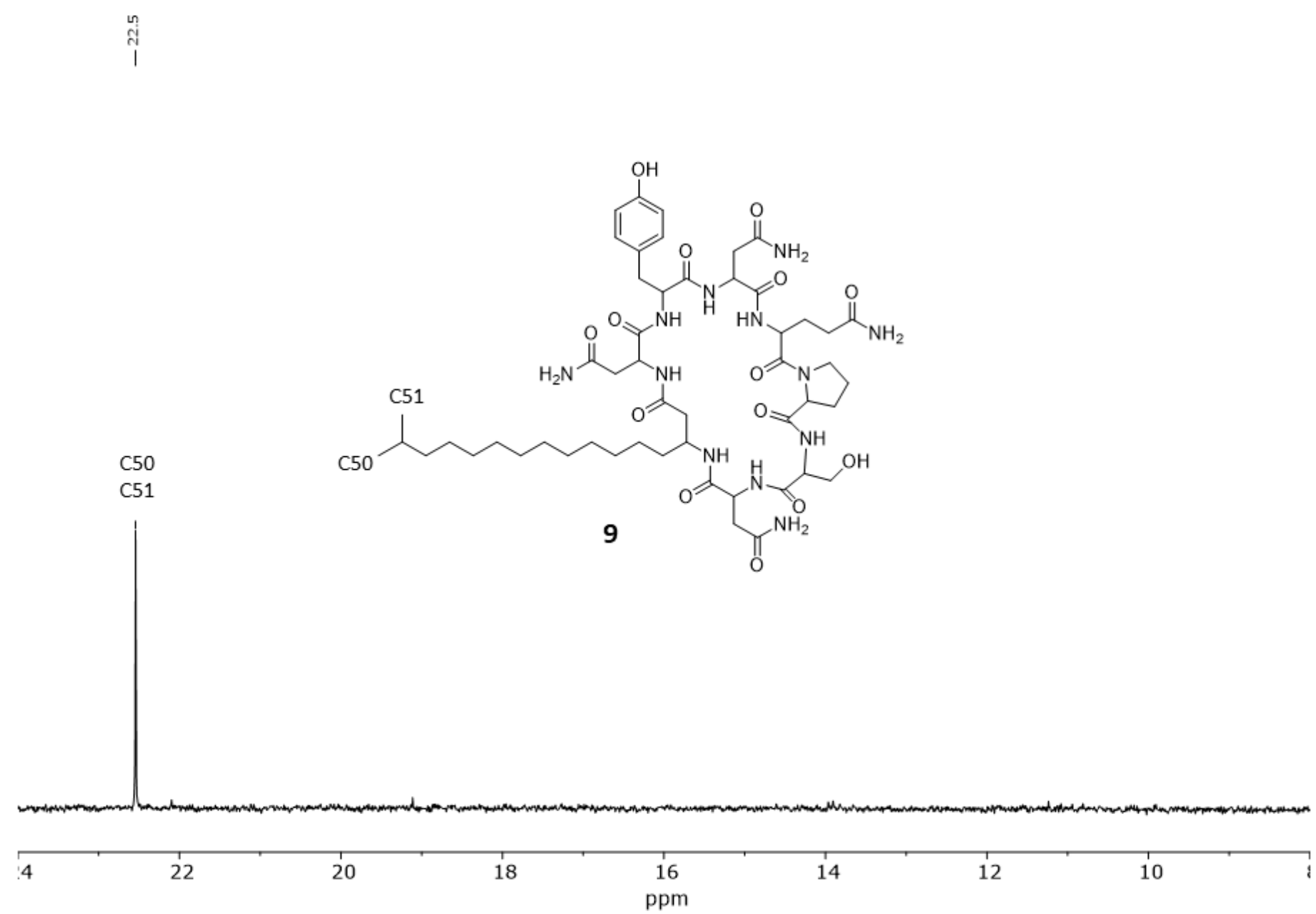

Figure S80. ${ }^{13} \mathrm{C}-\mathrm{NMR}$ spectrum of 9 in DMSO- $\mathrm{d}_{6}\left({ }^{13} \mathrm{C}: 200 \mathrm{MHz}\right)$, illustrating important methyl peaks used to determine chain branching. 


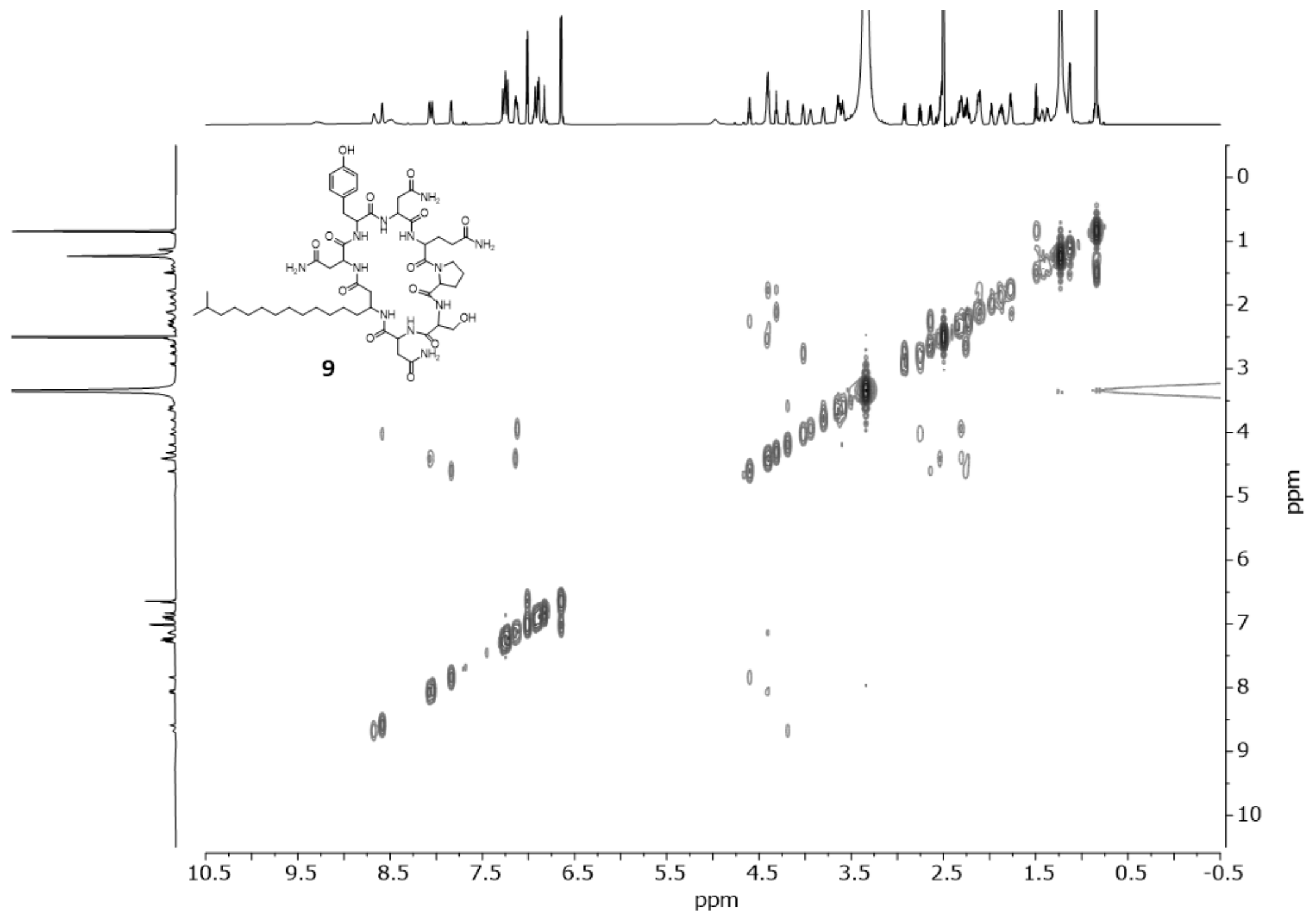

Figure S81. $\operatorname{COSY}\left({ }^{1} \mathrm{H}-{ }^{-1} \mathrm{H}\right)$ spectrum of 9 in DMSO- $\mathrm{d}_{6}(800 \mathrm{MHz})$. 


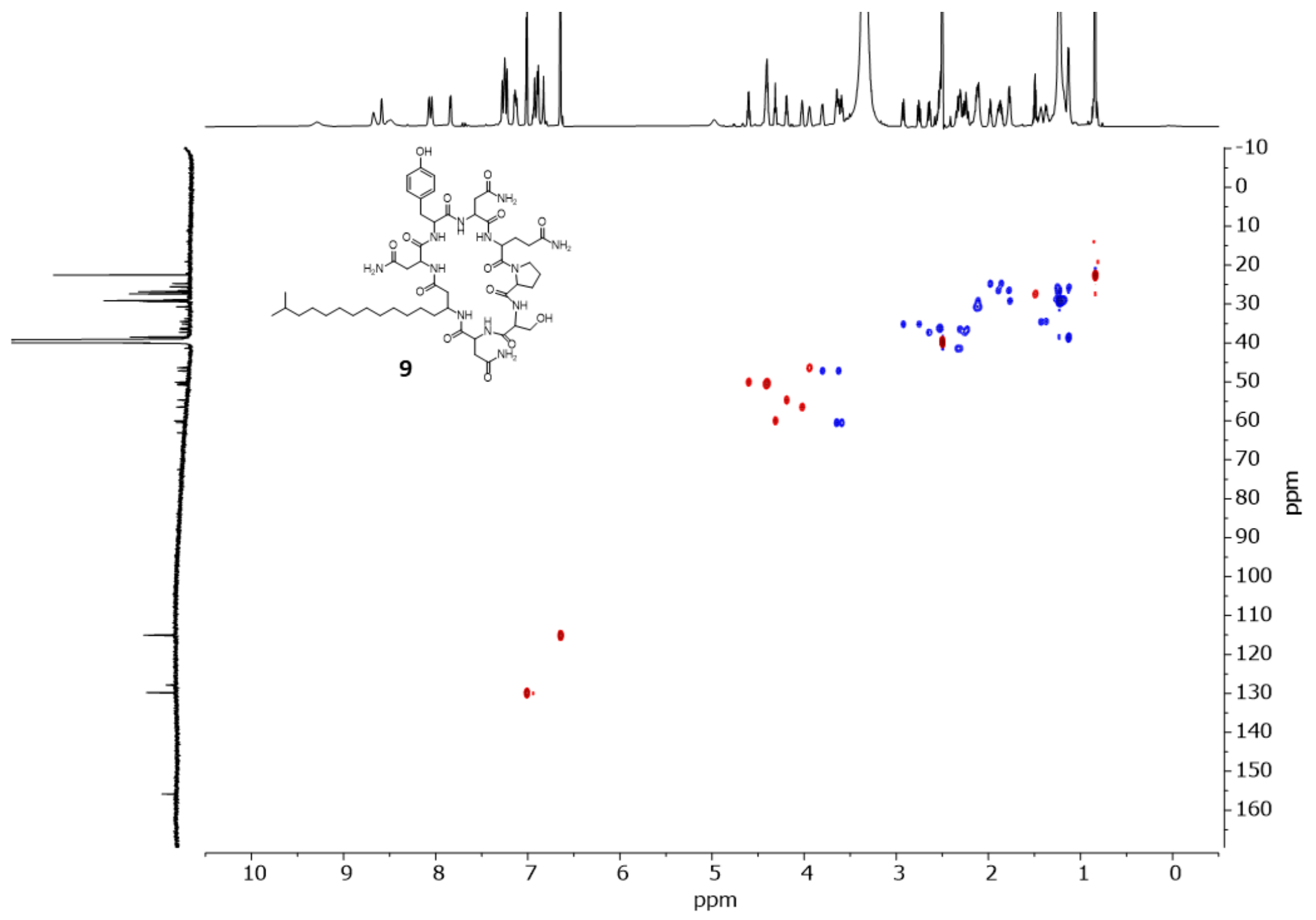

Figure S82. $\mathrm{HSQC}\left({ }^{1} \mathrm{H}_{-13}{ }^{13}\right)$ spectrum of 9 in DMSO- $\mathrm{d}_{6}$. Red contours represent $\mathrm{CH}$ and $\mathrm{CH}_{3}$ groups, blue contours represent $\mathrm{CH}_{2}$ groups. 


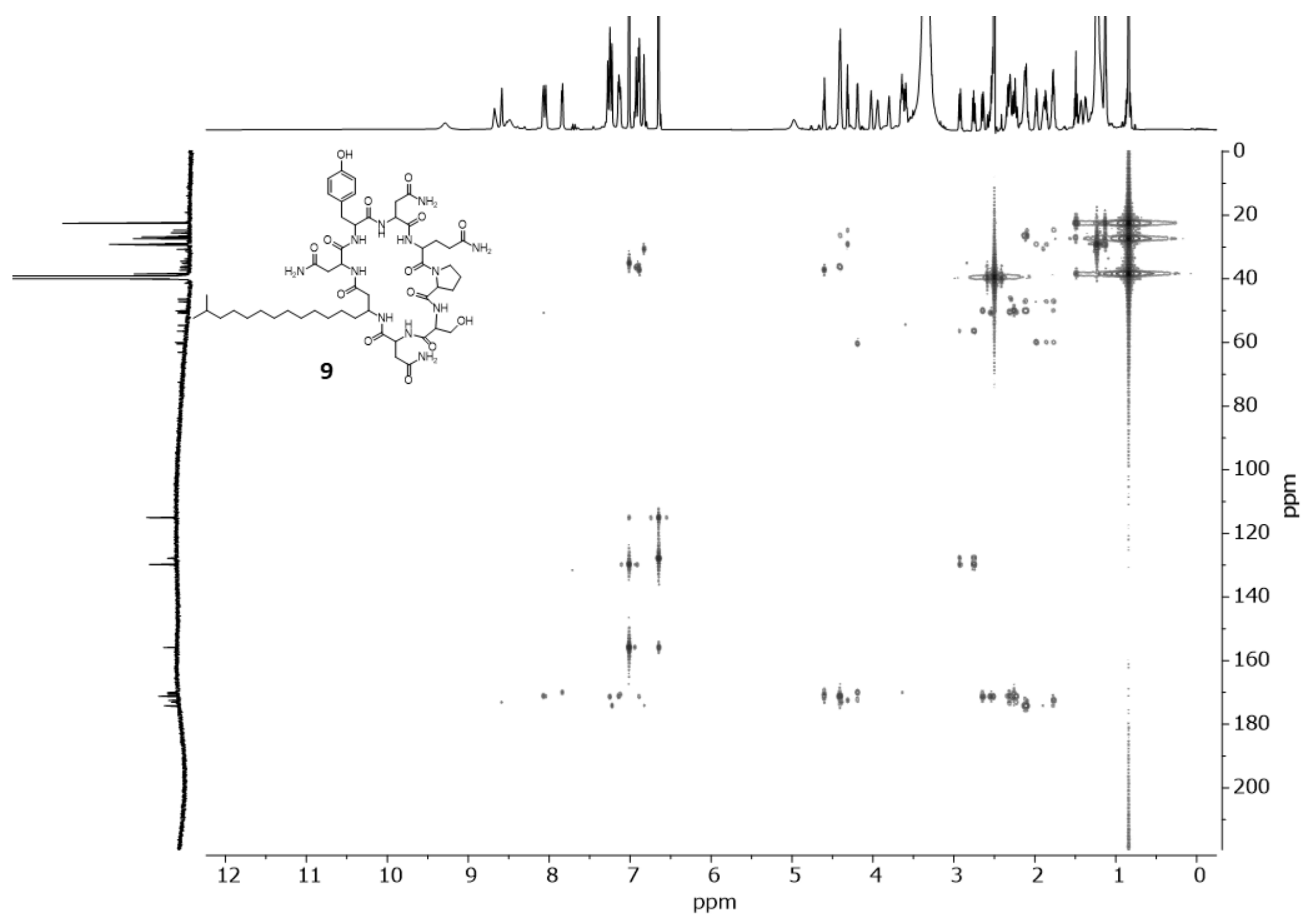

Figure S83. $\mathrm{HMBC}\left({ }^{1} \mathrm{H}-{ }^{13} \mathrm{C}\right)$ spectrum of 9 in DMSO- $\mathrm{d}_{6}$. 

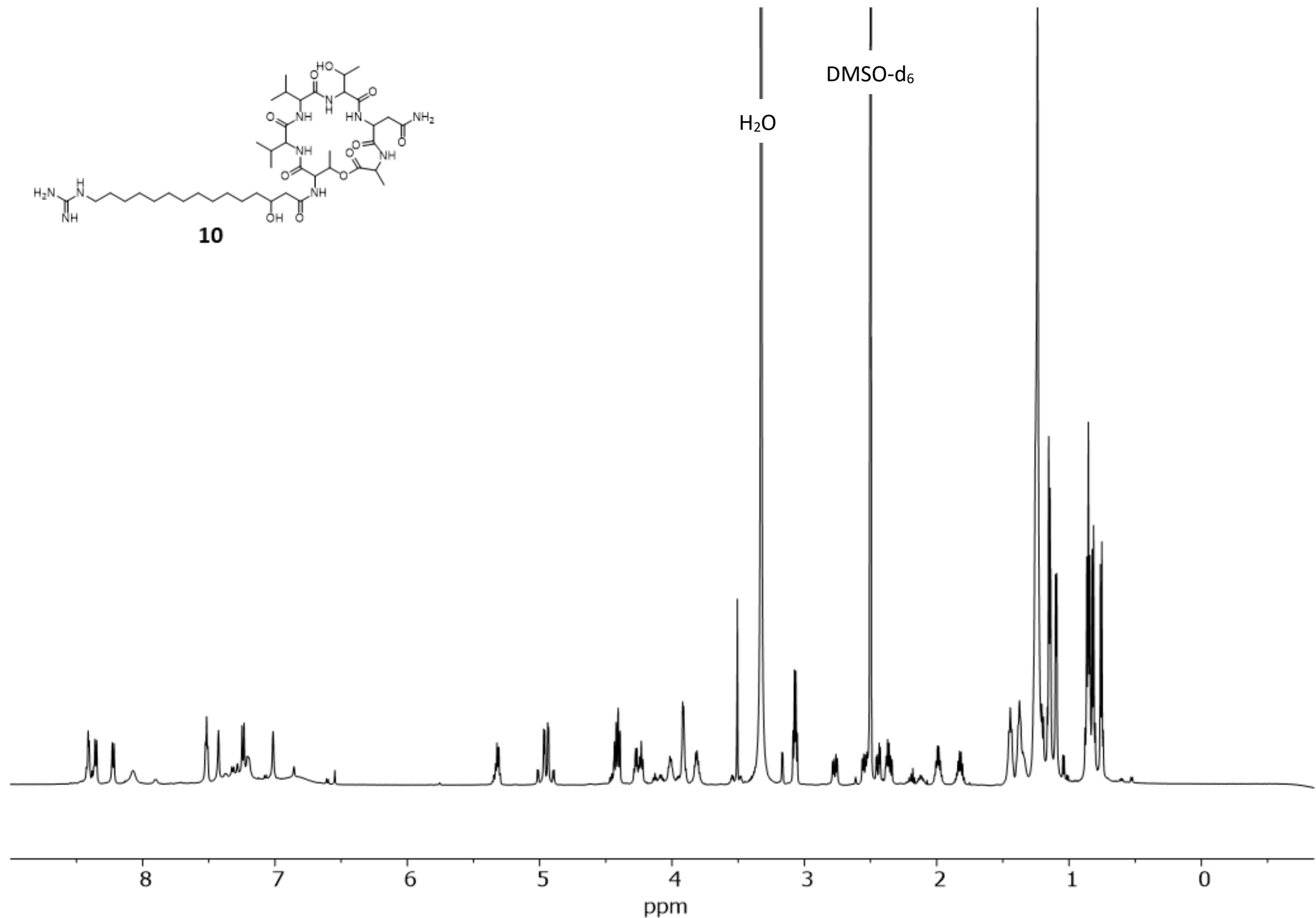

Figure S84. ${ }^{1} \mathrm{H}-\mathrm{NMR}$ spectrum of $10 \mathrm{in} \mathrm{DMSO}-\mathrm{d}_{6}\left({ }^{1} \mathrm{H}: 600 \mathrm{MHz}\right)$. 


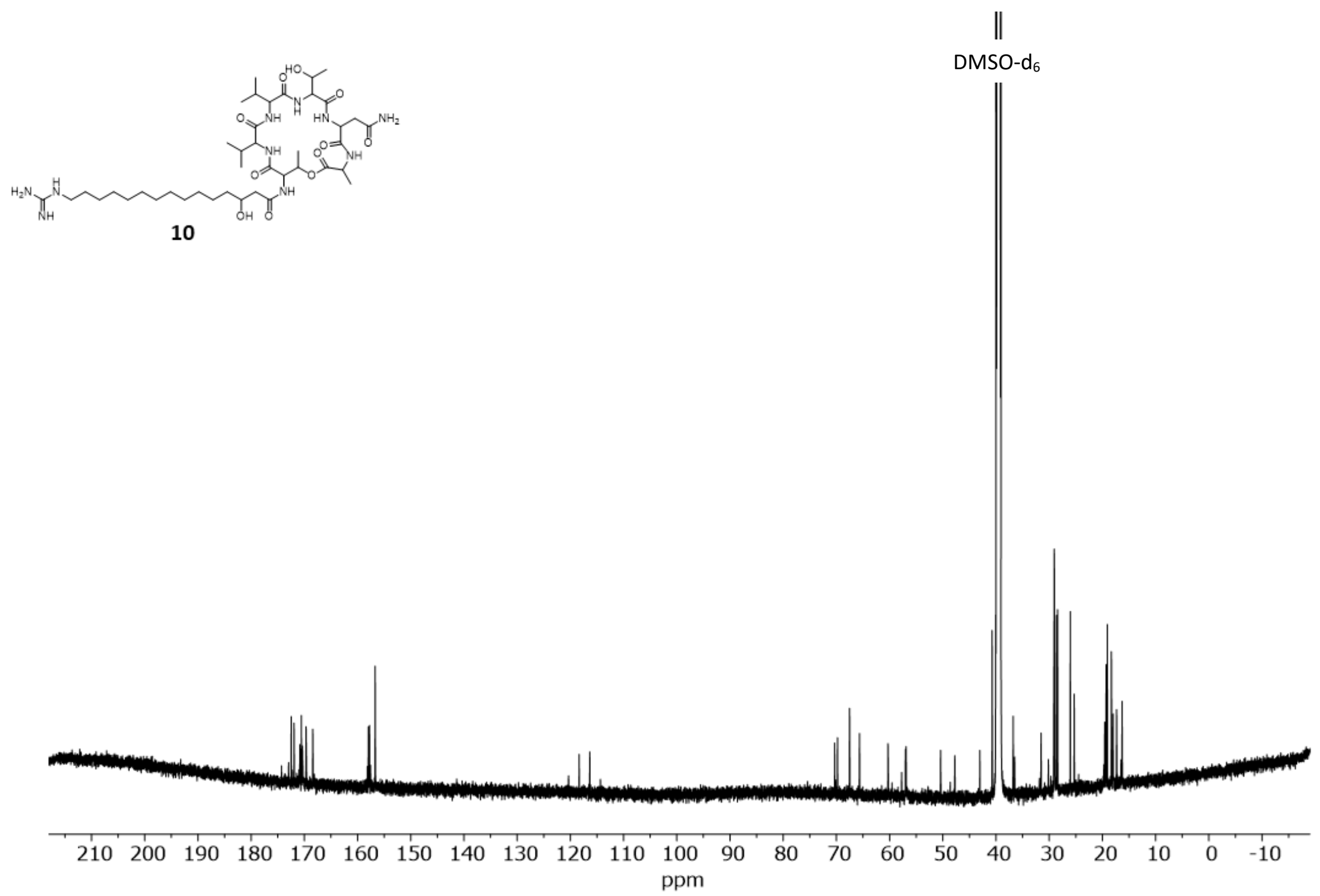

Figure S85. ${ }^{13} \mathrm{C}-\mathrm{NMR}$ spectrum of $\mathbf{1 0}$ in DMSO- $\mathrm{d}_{6}\left({ }^{13} \mathrm{C}: 150 \mathrm{MHz}\right)$. 


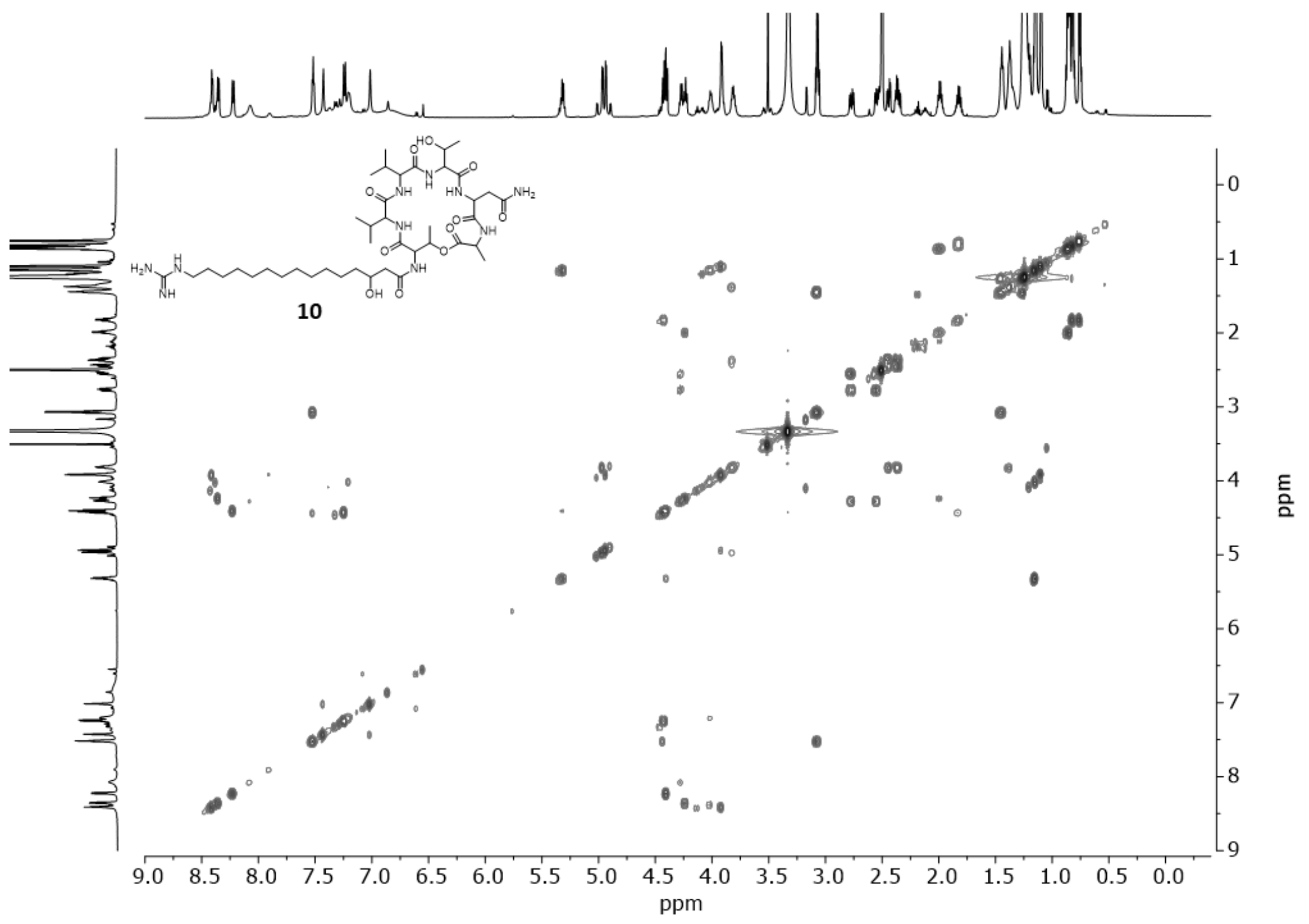

Figure S86. COSY $\left({ }^{1} \mathrm{H}-{ }^{1} \mathrm{H}\right)$ spectrum of 10 in DMSO-d 6 (600 MHz). 


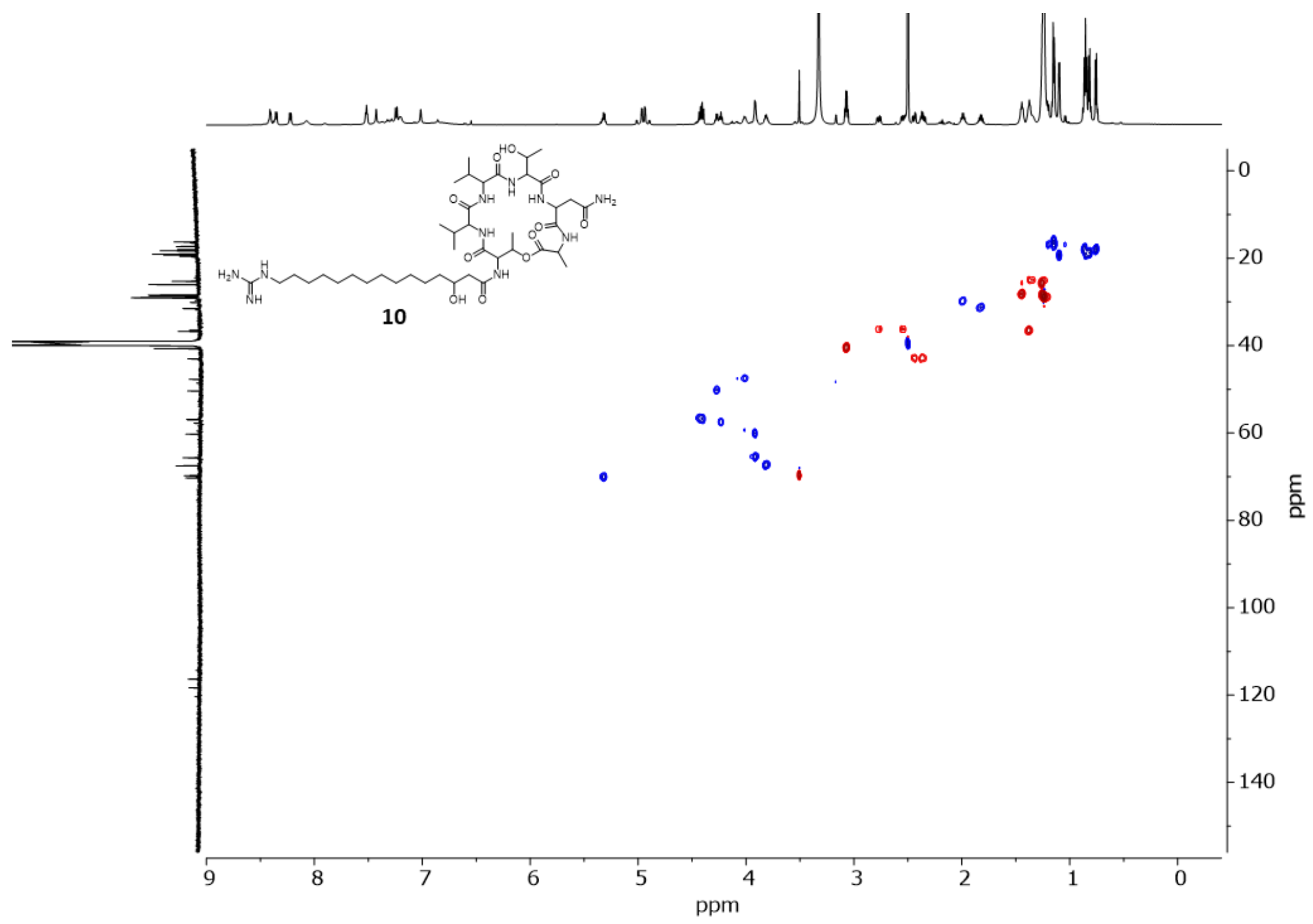

Figure S87. $\mathrm{HSQC}\left({ }^{1} \mathrm{H}^{13} \mathrm{C}\right)$ spectrum of 10 in $\mathrm{DMSO}-\mathrm{d}_{6}$. Blue contours represent $\mathrm{CH}$ and $\mathrm{CH}_{3}$ groups, red contours represent $\mathrm{CH}_{2}$ groups. 


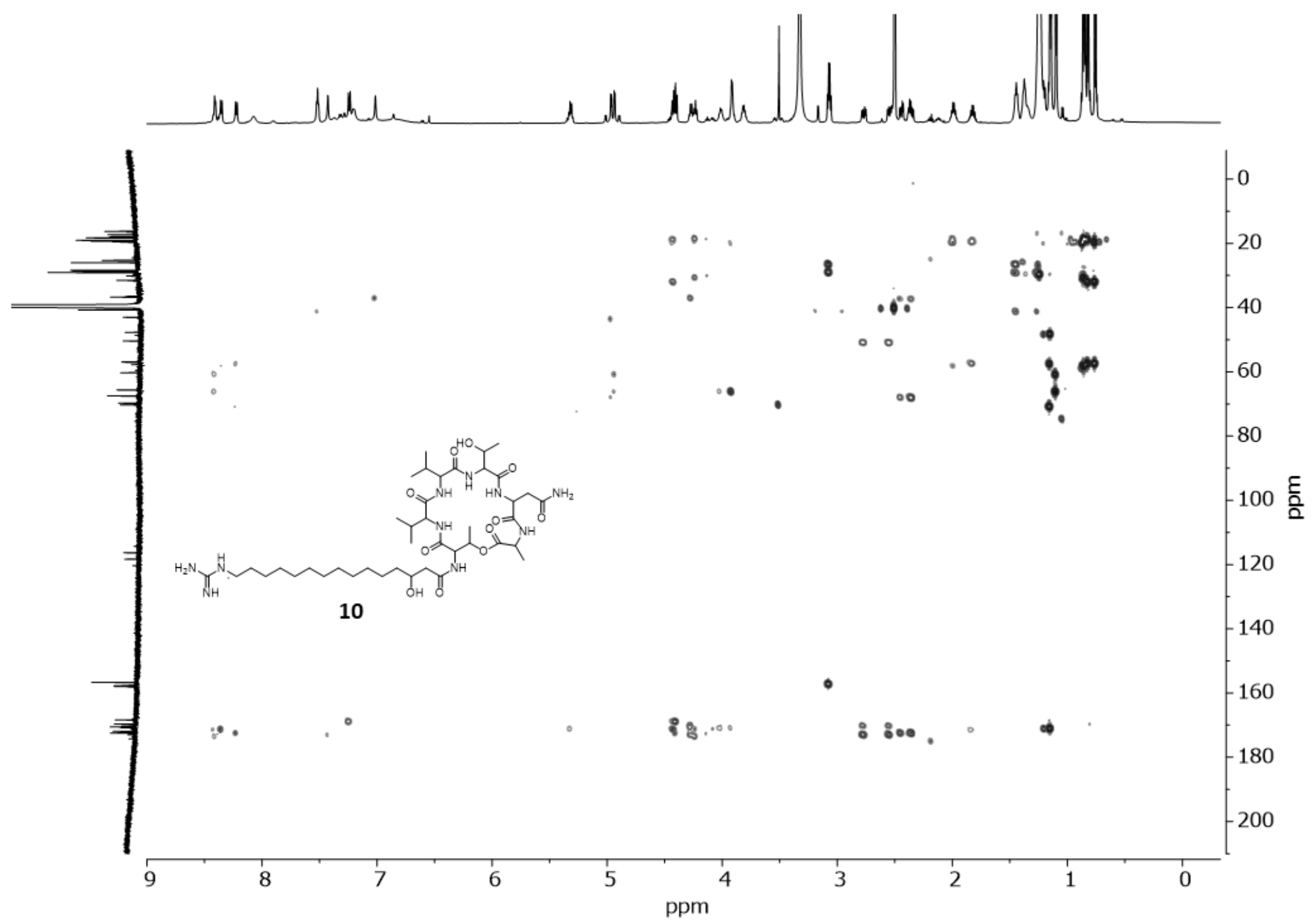

Figure S88. $\mathrm{HMBC}\left({ }^{1} \mathrm{H}-{ }^{13} \mathrm{C}\right)$ spectrum of $\mathbf{1 0}$ in DMSO- $\mathrm{d}_{6}$. 


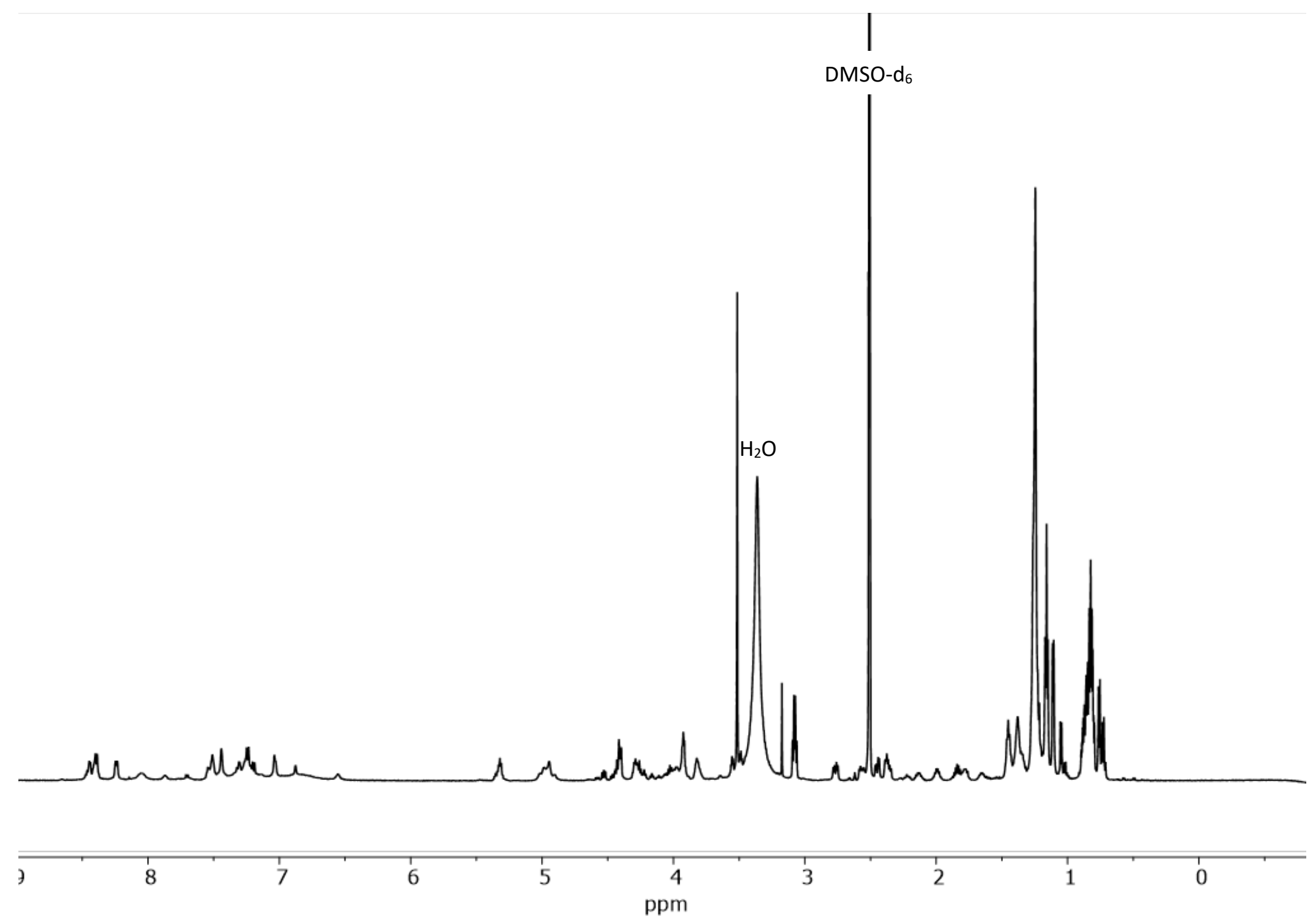

Figure S89. ${ }^{1} \mathrm{H}-\mathrm{NMR}$ spectrum of 11 in DMSO-d $\mathrm{d}_{6}\left({ }^{1} \mathrm{H}: 600 \mathrm{MHz}\right)$. 


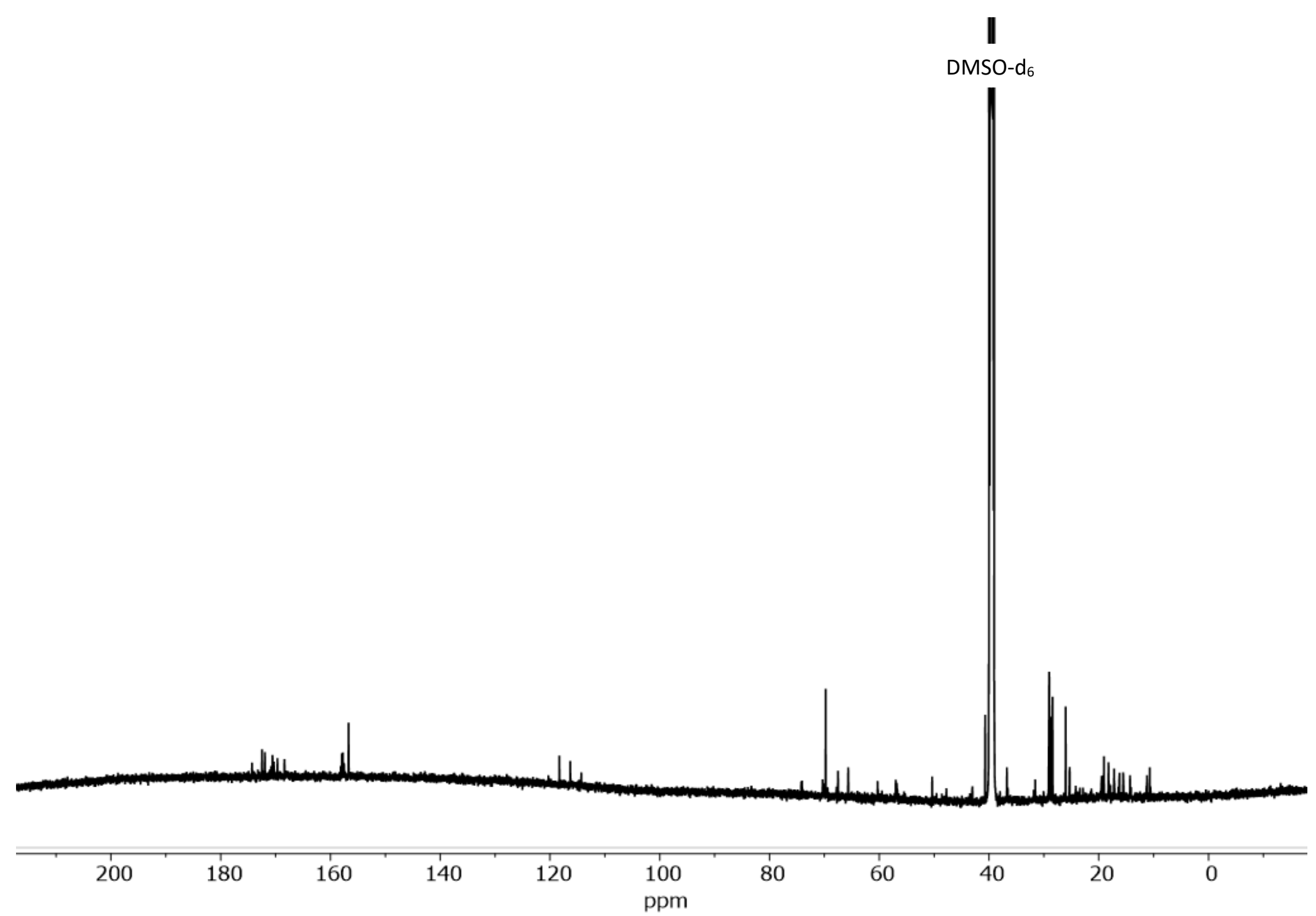

Figure S90. ${ }^{13} \mathrm{C}-\mathrm{NMR}$ spectrum of 11 in DMSO-d $\mathrm{d}_{6}\left({ }^{13} \mathrm{C}: 150 \mathrm{MHz}\right)$. 


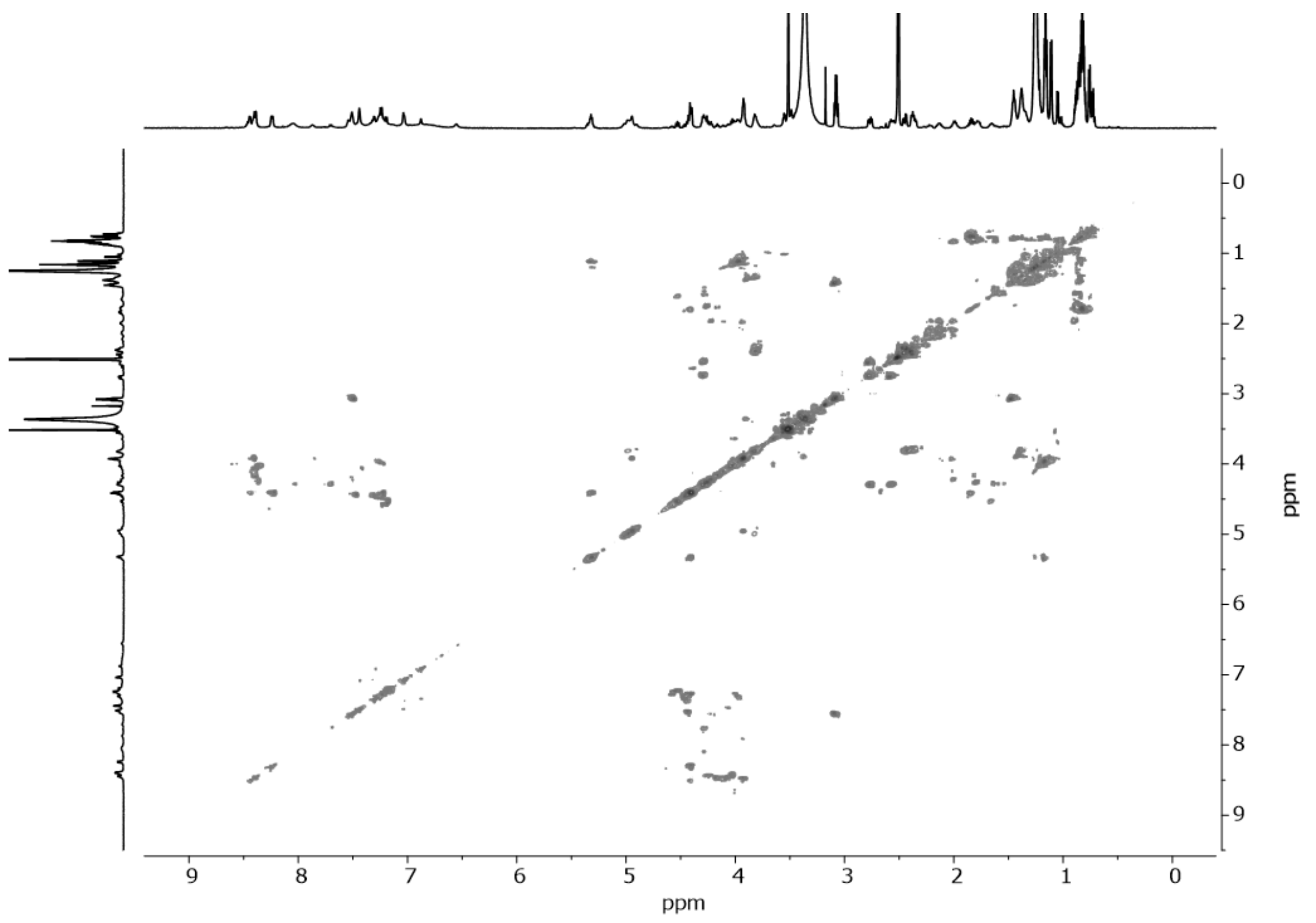

Figure S91. COSY $\left({ }^{1} \mathrm{H}-{ }^{1} \mathrm{H}\right)$ spectrum of 11 in DMSO-d 6 (600 MHz). 


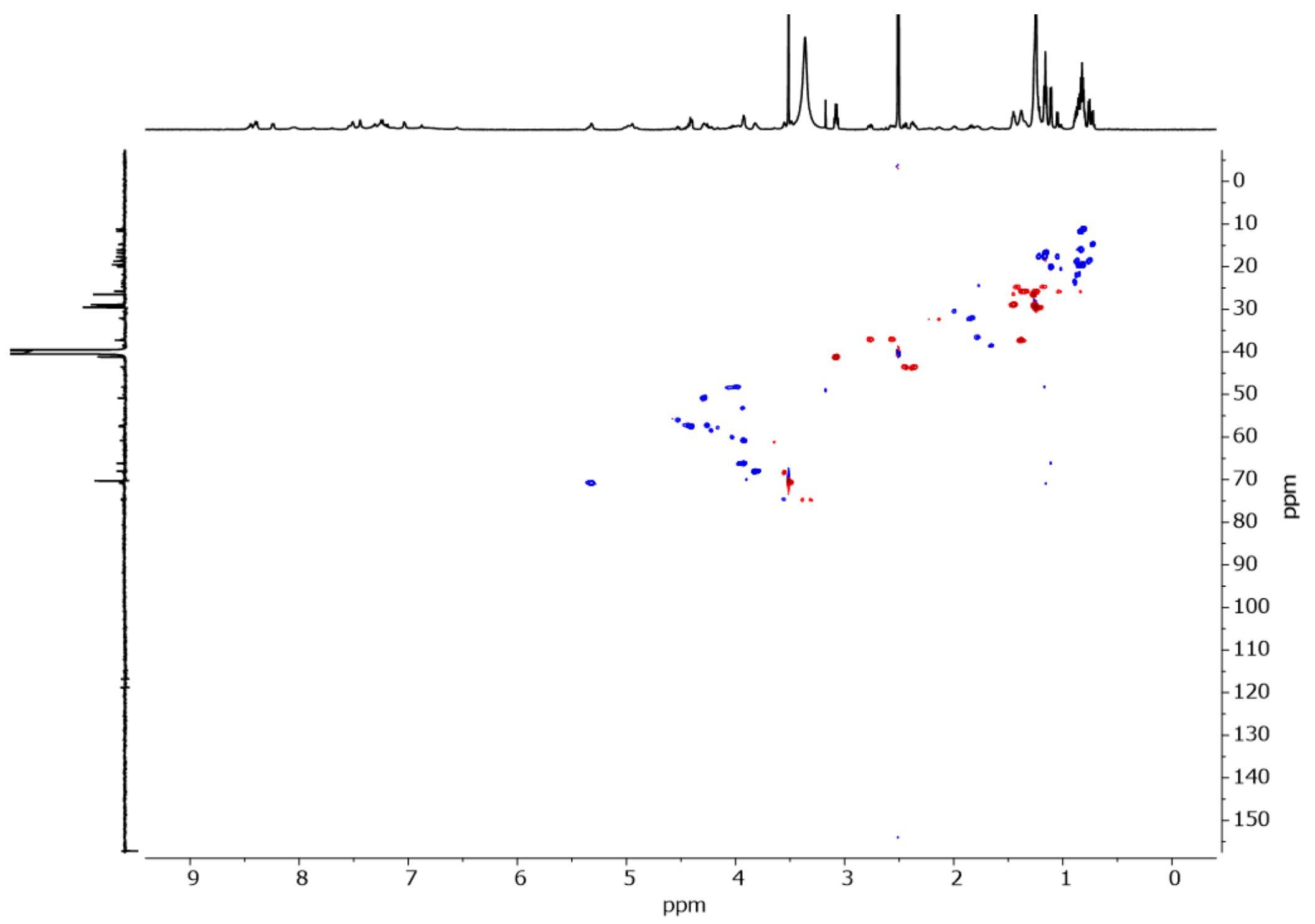

Figure S92. $\mathrm{HSQC}\left({ }^{1} \mathrm{H}^{13} \mathrm{C}\right)$ spectrum of $\mathbf{1 1}$ in DMSO- $\mathrm{d}_{6}$. Red contours represent $\mathrm{CH}$ and $\mathrm{CH}_{3}$ groups, blue contours represent $\mathrm{CH}_{2}$ groups. 


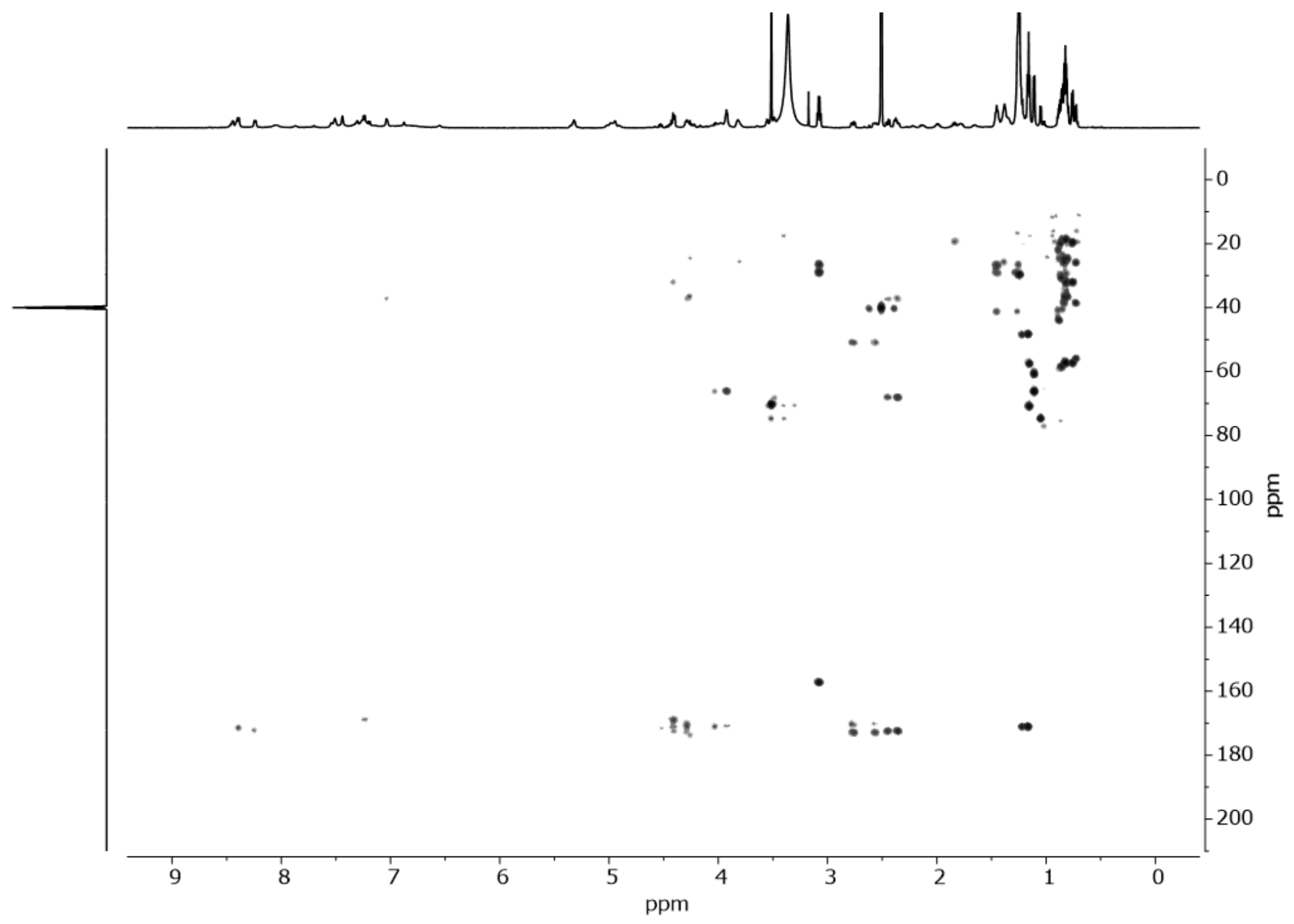

Figure S93. $\mathrm{HMBC}\left({ }^{1} \mathrm{H}-{ }^{13} \mathrm{C}\right)$ spectrum of $\mathbf{1 1}$ in DMSO- $\mathrm{d}_{6}$. 


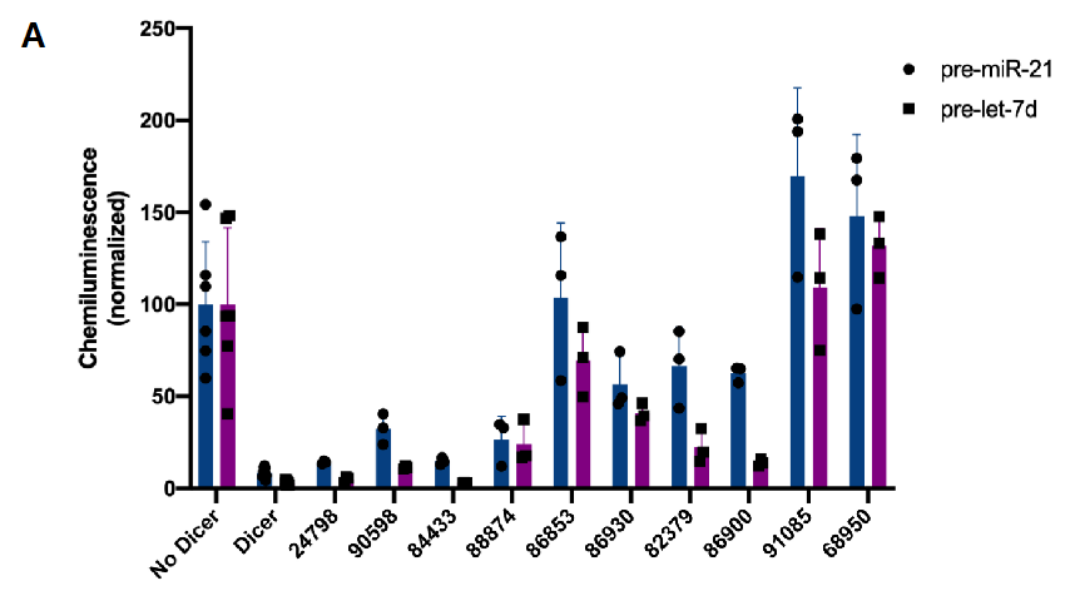

B

\begin{tabular}{lcc} 
& \multicolumn{2}{c}{$\%$ Inhibition } \\
\cline { 2 - 3 } Strain & pre-miR-21 & pre-let-7d \\
24798 & $14 \pm 1$ & $5 \pm 1$ \\
90598 & $32 \pm 8$ & $11 \pm 1$ \\
84433 & $15 \pm 2$ & $3 \pm 0.2$ \\
88874 & $26 \pm 13$ & $24 \pm 12$ \\
86853 & $104 \pm 40$ & $69 \pm 19$ \\
86930 & $56 \pm 15$ & $41 \pm 5$ \\
\hline 82379 & $66 \pm 21$ & $22 \pm 9$ \\
\hline 86900 & $62 \pm 4$ & $14 \pm 2$ \\
91085 & $170 \pm 48$ & $109 \pm 32$ \\
68950 & $148 \pm 44$ & $132 \pm 17$
\end{tabular}
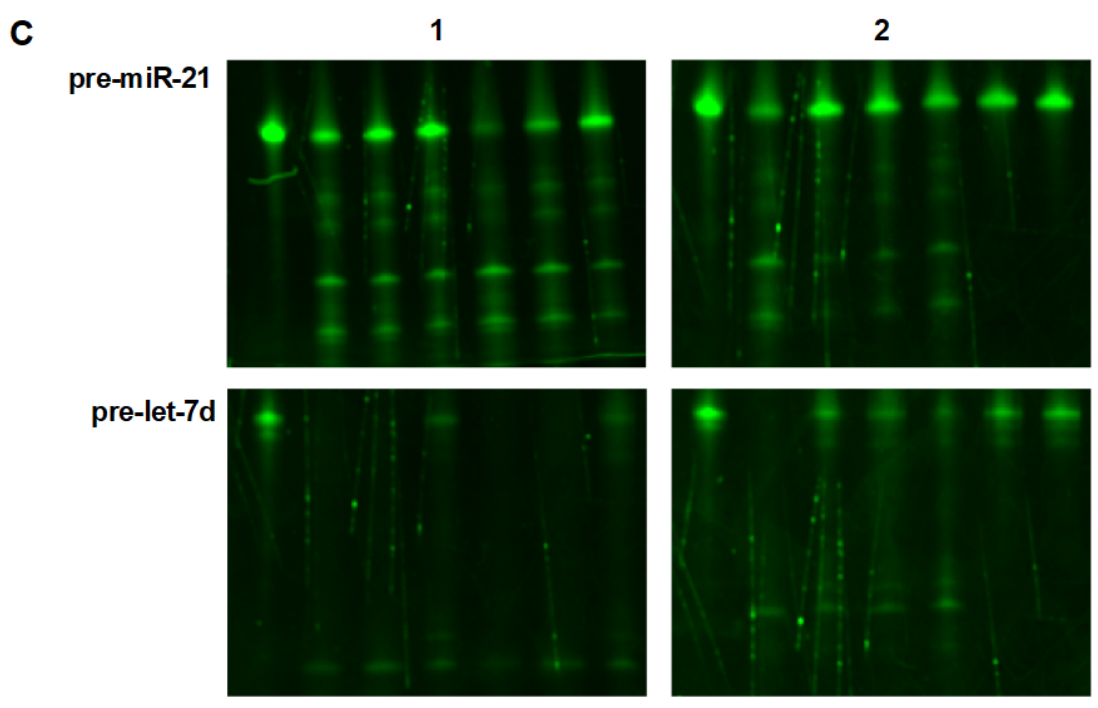

L to $R$ :

Gel 1

Dicer

24798

90598

84433

88874

86853

Gel 2

No Dicer

Dicer

86930

82379

86900

91085

68950

Figure S94. Activity of top 10 NPEs identified from cat-ELCCA screening for inhibiting pre-miR-21 processing by Dicer. \% inhibition at $75 \mathrm{~g} / \mathrm{mL}$ is shown. For all assays, pre-let-7d was used as a control to determine selectivity. (A) HTS data. (B) Tabulated \% inhibitions. Surfactin-producing strain $\mathbf{8 2 3 7 9}$ is boxed. 
A

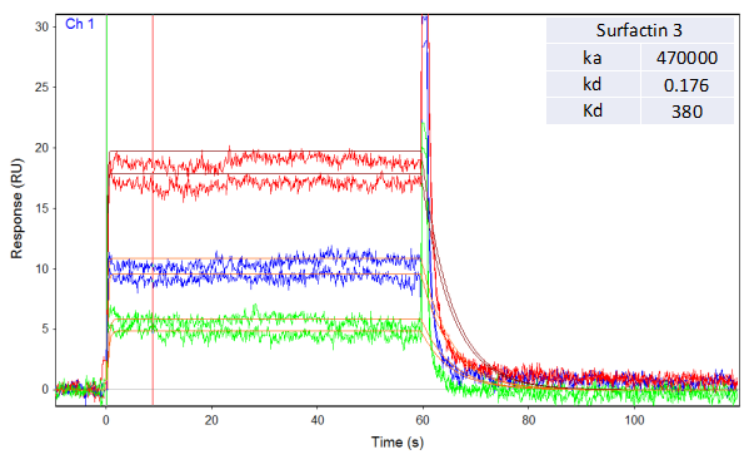

C

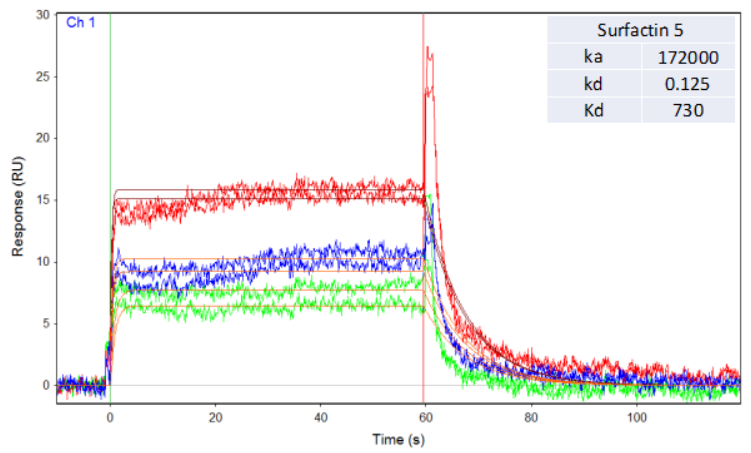

B

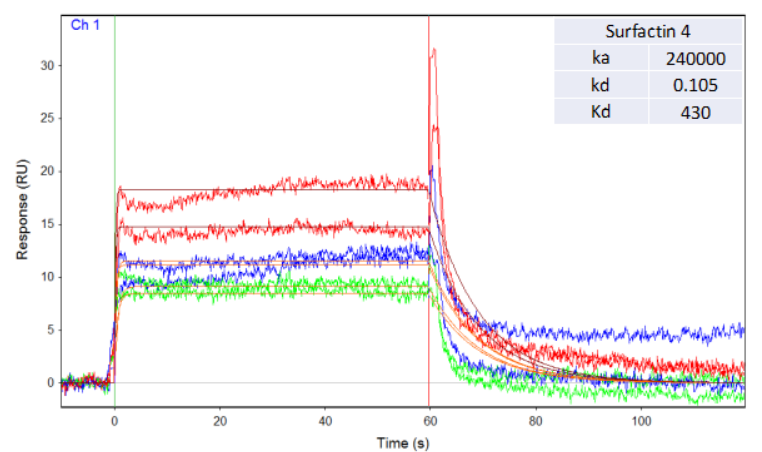

D

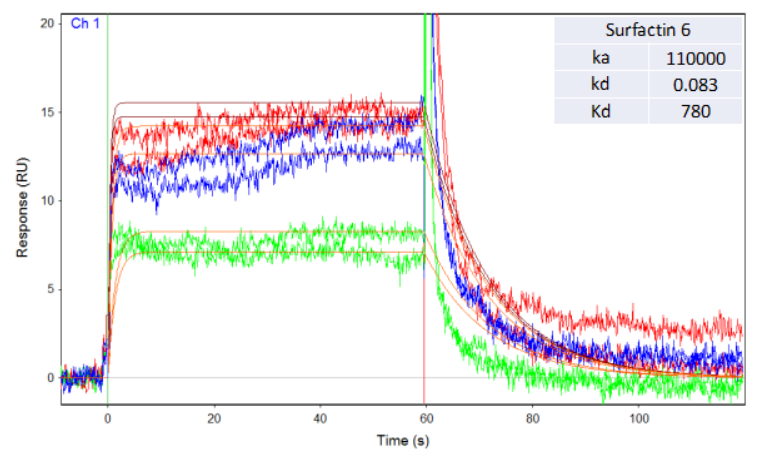

Figure S95. Direct binding of surfactins 3-6 (A-D) to pre-miR-21 measured via SPR.

A

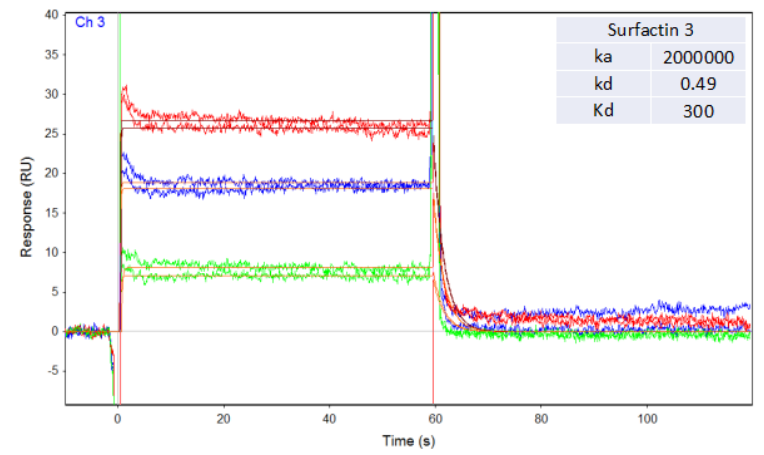

C

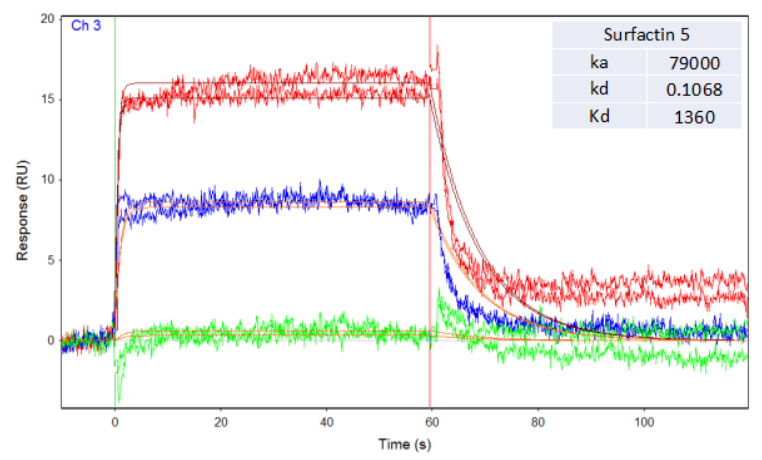

B
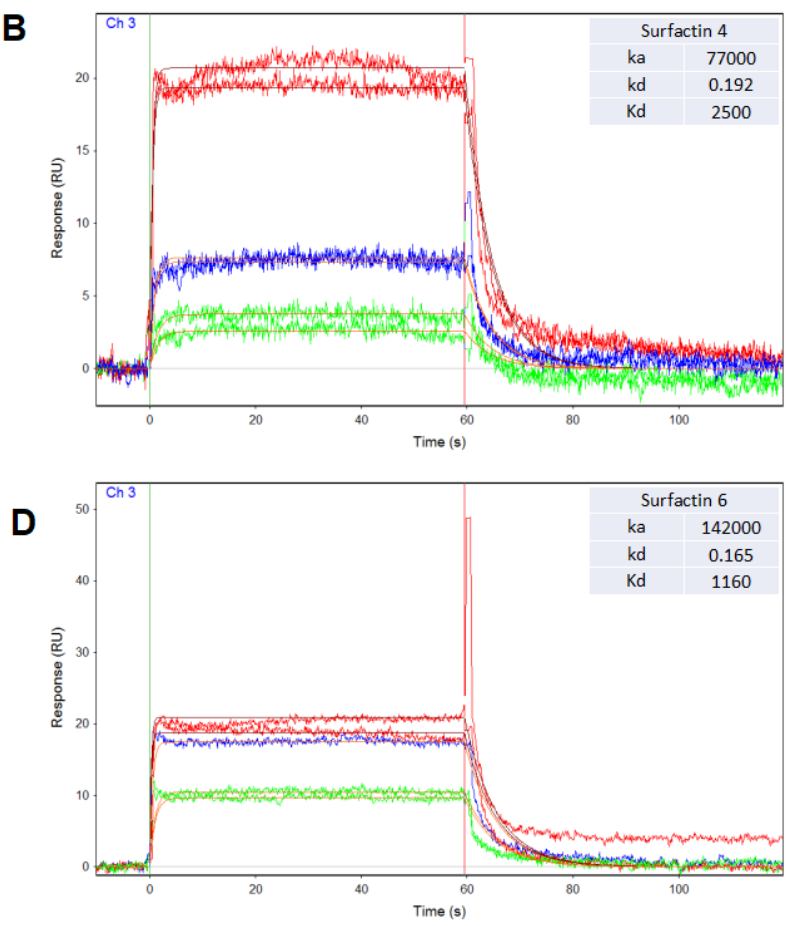

Figure S96. Direct binding of surfactins 3-6 (A-D) to pre-let-7d measured via SPR. 


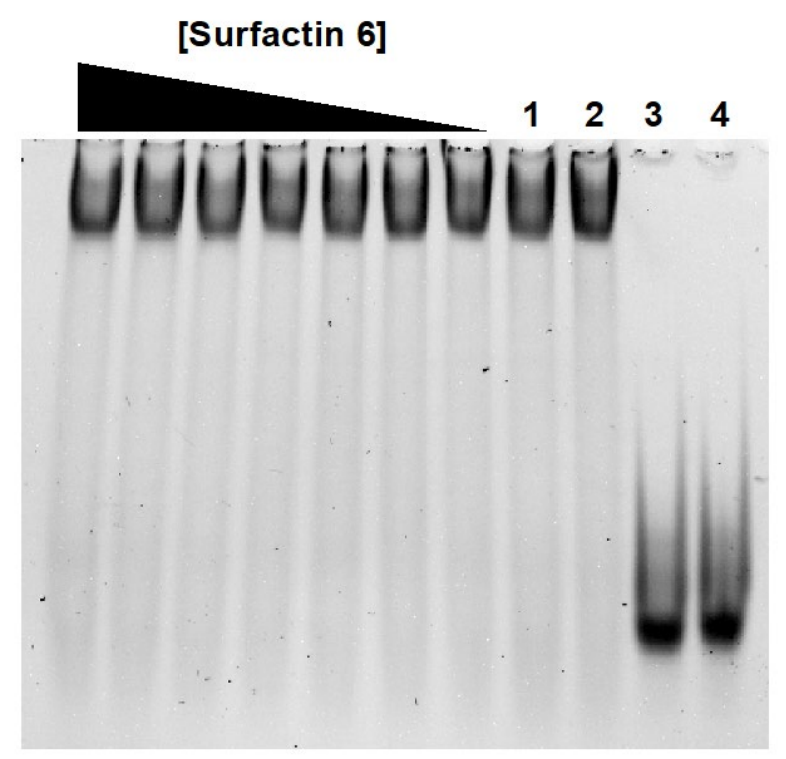

Figure S97. Electrophoretic mobility shift assay (EMSA) analysis of pre-miR-21 binding to Dicer in the presence of surfactin 6. Surfactin 6 was tested from 10-120 $\mu \mathrm{M}$. Control Lane $1=$ pre-miR-21 + Dicer + buffer. Control Lane 2 = pre-miR-21 + Dicer + DMSO. Control Lane 3 = pre-miR-21 + buffer. Control Lane 4 $=$ pre-miR-21 + DMSO.

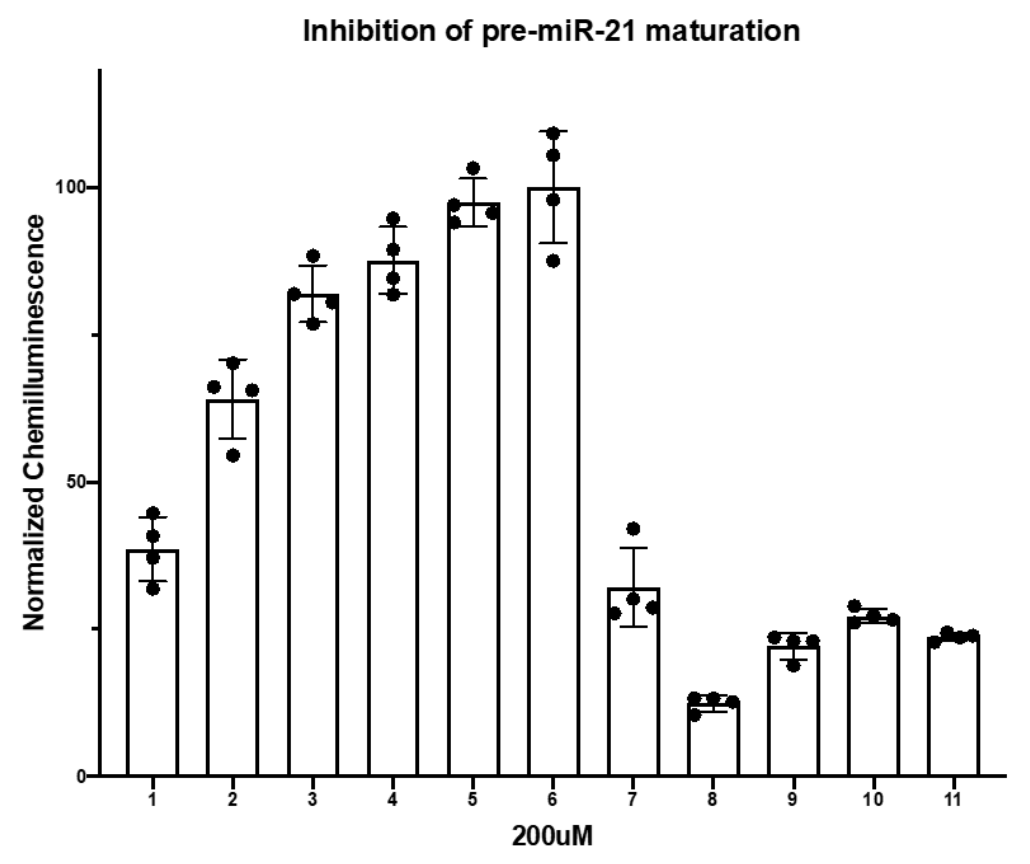

Figure S98. Single concentration (200 $\mu \mathrm{M})$ comparative analysis of compounds 1-11 inhibiting pre-miR-21 maturation. 


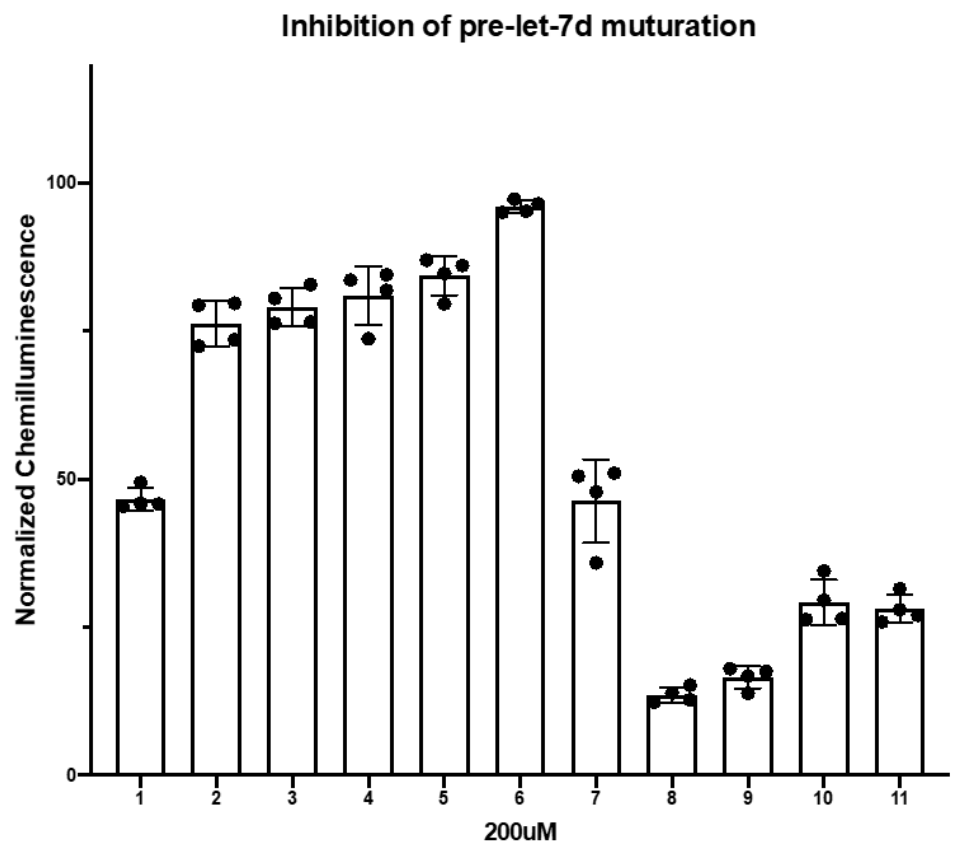

Figure 599. Single concentration (200 $\mu \mathrm{M})$ comparative analysis of compounds 1-11 inhibiting pre-let-7d maturation.

A
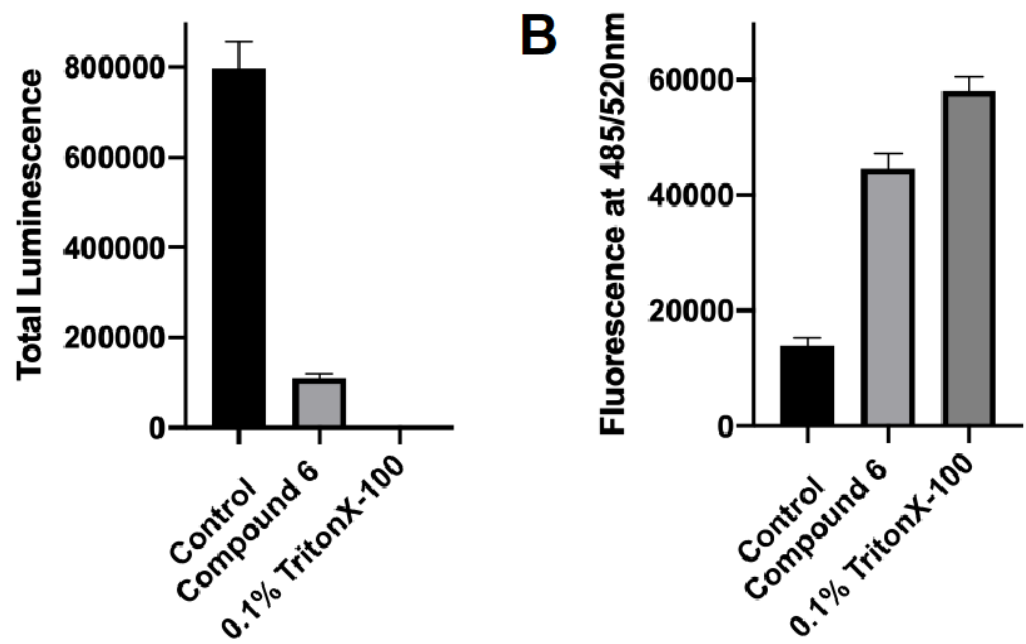

Figure S100. Impact of surfactin $6(100 \mu \mathrm{M})$ on HeLa cell growth. TritonX-100 was used as a control compound due to its role as a detergent-based membrane disruptor. (A) Cell viability as measured using the CellTiter Glo assay. (B) Cell cytotoxicity as measured using the CellTox Green assay. 


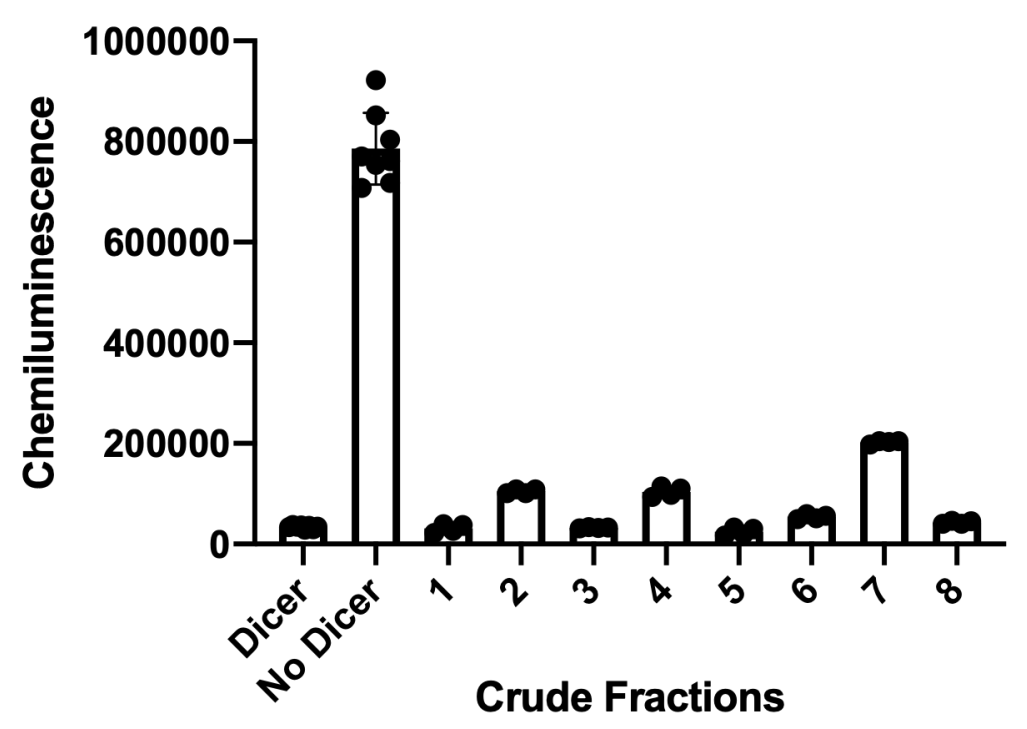

Figure S101. Activity of crude fractions from C18 reverse-phase flash chromatography in the cat-ELCCA, illustrating fraction 7 (F7) as the fraction of interest.

1. Magarvey, N. A.; Keller, J. M.; Bernan, V.; Dworkin, M.; Sherman, D. H., Isolation and characterization of novel marine-derived actinomycete taxa rich in bioactive metabolites. Appl Environ Microbiol 2004, 70 (12), 7520-7529.

2. $\quad$ Park, S. R.; Tripathi, A.; Wu, J.; Schultz, P. J.; Yim, I.; McQuade, T. J.; Yu, F.; Arevang, C.-J.; Mensah, A. Y.; Tamayo-Castillo, G.; Xi, C.; Sherman, D. H., Discovery of cahuitamycins as biofilm inhibitors derived from a convergent biosynthetic pathway. Nat Commun 2016, 7, 10710-10710.

3. Yamamura, H.; Hayakawa, M.; limura, Y., Application of sucrose-gradient centrifugation for selective isolation of Nocardia spp. from soil. J Appl Microbiol 2003, 95 (4), 677-85.

4. Hayakawa, M.; Nonomura, H., Humic acid-vitamin agar, a new medium for the selective isolation of soil actinomycetes. Journal of Fermentation Technology 1987, 65 (5), 501-509.

5. $\quad$ Chambers, M. C.; Maclean, B.; Burke, R.; Amodei, D.; Ruderman, D. L.; Neumann, S.; Gatto, L.; Fischer, B.; Pratt, B.; Egertson, J.; Hoff, K.; Kessner, D.; Tasman, N.; Shulman, N.; Frewen, B.; Baker, T. A.; Brusniak, M.-Y.; Paulse, C.; Creasy, D.; Flashner, L.; Kani, K.; Moulding, C.; Seymour, S. L.; Nuwaysir, L. M.; Lefebvre, B.; Kuhlmann, F.; Roark, J.; Rainer, P.; Detlev, S.; Hemenway, T.; Huhmer, A.; Langridge, J.; Connolly, B.; Chadick, T.; Holly, K.; Eckels, J.; Deutsch, E. W.; Moritz, R. L.; Katz, J. E.; Agus, D. B.; MacCoss, M.; Tabb, D. L.; Mallick, P., A cross-platform toolkit for mass spectrometry and proteomics. Nat Biotechnol 2012, 30 (10), 918-920.

6. Wang, M.; Carver, J. J.; Phelan, V. V.; Sanchez, L. M.; Garg, N.; Peng, Y.; Nguyen, D. D.; Watrous, J.; Kapono, C. A.; Luzzatto-Knaan, T.; Porto, C.; Bouslimani, A.; Melnik, A. V.; Meehan, M. J.; Liu, W. T.; Crüsemann, M.; Boudreau, P. D.; Esquenazi, E.; Sandoval-Calderón, M.; Kersten, R. D.; Pace, L. A.; Quinn, R. A.; Duncan, K. R.; Hsu, C. C.; Floros, D. J.; Gavilan, R. G.; Kleigrewe, K.; Northen, T.; Dutton, R. J.; Parrot, D.; Carlson, E. E.; Aigle, B.; Michelsen, C. F.; Jelsbak, L.; Sohlenkamp, C.; Pevzner, P.; Edlund, A.; McLean, J.; Piel, J.; Murphy, B. T.; Gerwick, L.; Liaw, C. C.; Yang, Y. L.; Humpf, H. U.; Maansson, M.; Keyzers, R. A.; Sims, A. C.; Johnson, A. R.; Sidebottom, A. M.; Sedio, B. E.; Klitgaard, A.; Larson, C. B.; P, C. A. B.; Torres-Mendoza, D.; Gonzalez, D. J.; Silva, D. B.; Marques, L. M.; Demarque, D. P.; Pociute, E.; O'Neill, E. C.; Briand, E.; Helfrich, E. J. N.; Granatosky, E. A.; Glukhov, E.; Ryffel, F.; Houson, H.; Mohimani, H.; Kharbush, J. J.; Zeng, Y.; Vorholt, J. A.; Kurita, K. L.; Charusanti, P.; McPhail, K. L.; Nielsen, 
K. F.; Vuong, L.; Elfeki, M.; Traxler, M. F.; Engene, N.; Koyama, N.; Vining, O. B.; Baric, R.; Silva, R. R.; Mascuch, S. J.; Tomasi, S.; Jenkins, S.; Macherla, V.; Hoffman, T.; Agarwal, V.; Williams, P. G.; Dai, J.; Neupane, R.; Gurr, J.; Rodríguez, A. M. C.; Lamsa, A.; Zhang, C.; Dorrestein, K.; Duggan, B. M.; Almaliti, J.; Allard, P. M.; Phapale, P.; Nothias, L. F.; Alexandrov, T.; Litaudon, M.; Wolfender, J. L.; Kyle, J. E.; Metz, T. O.; Peryea, T.; Nguyen, D. T.; VanLeer, D.; Shinn, P.; Jadhav, A.; Müller, R.; Waters, K. M.; Shi, W.; Liu, X.; Zhang, L.; Knight, R.; Jensen, P. R.; Palsson, B. O.; Pogliano, K.; Linington, R. G.; Gutiérrez, M.; Lopes, N. P.; Gerwick, W. H.; Moore, B. S.; Dorrestein, P. C.; Bandeira, N., Sharing and community curation of mass spectrometry data with Global Natural Products Social Molecular Networking. (15461696 (Electronic)).

7. Shannon, P.; Markiel, A.; Ozier, O.; Baliga, N. S.; Wang, J. T.; Ramage, D.; Amin, N.; Schwikowski, B.; Ideker, T., Cytoscape: a software environment for integrated models of biomolecular interaction networks. Genome Res 2003, 13 (11), 2498-504.

8. Ratnayake, A. S.; Bugni, T. S.; Feng, X.; Harper, M. K.; Skalicky, J. J.; Mohammed, K. A.; Andjelic, C. D.; Barrows, L. R.; Ireland, C. M., Theopapuamide, a cyclic depsipeptide from a Papua New Guinea lithistid sponge Theonella swinhoei. J Nat Prod 2006, 69 (11), 1582-1586.

9. Garner, A. L.; Lorenz, D. A.; Gallagher, E. E., A click chemistry assay to identify natural product ligands for pre-microRNAs. Methods Enzymol. 2019, 623, 85-99.

10. Bouvette, J.; Korkut, D. N.; Fouillen, A.; Amellah, S.; Nanci, A.; Durocher, Y.; Omichinski, J. G.; Legault, P., High-yield production of human Dicer by transfection of human HEK293-EBNA1 cells grown in suspension. BMC biotechnology 2018, 18 (1), 76. 